\title{
Modeling estuaries as eco-engineered landscapes
}

How species shape the morphology of past, present and future estuaries

\section{Modellering van bio-bouwers in estuaria}

De invloed van soorten op de morfologie van estuaria in het verleden, heden en de toekomst

(met een samenvatting in het Nederlands)

\section{P R O E F S C H R I F T}

ter verkrijging van de graad van doctor aan de Universiteit Utrecht op gezag van de rector magnificus, prof. dr. H.R.B.M. Kummeling, ingevolge het besluit van het college voor promoties in het openbaar te verdedigen op maandag 15 februari 2021 des middags te 4.15 uur

door

Muriel Zazie Madeleine Brückner

geboren op 6 augustus 1989 te Würzburg, Duitsland 


\section{Promotor:}

Prof. dr. M. G. Kleinhans

\section{Copromotor:}

Dr. C. Schwarz

This research was funded by the ERC Consolidator project 647570 . 
Utrecht Studies in Earth Sciences 226

Modeling estuaries as eco-engineered landscapes

How species shape the morphology of past, present and future estuaries

Muriel Z.M. Brückner

Utrecht 2021

Faculty of Geosciences, Utrecht University 


\section{Promotor:}

Prof. dr. M. G. Kleinhans

\section{Copromotor:}

Dr. C. Schwarz

\section{Examination committee:}

Prof. dr. I. Möller

Trinity College Dublin, Ireland

Prof. dr. A. D’Alpaos

University of Padova, Italy

Prof. dr. P.M.J. Herman

Delft University of Technology, The Netherlands

Prof. dr. K.R. Bryan

University of Waikato, New Zealand

Prof. dr. D. Van der Wal

University of Twente, The Netherlands

ISBN 978-90-6266-590-7

Published by Faculty of Geosciences, Universiteit Utrecht, The Netherlands, in:

Utrecht Studies in Earth Sciences (USES), ISSN 2211-4335

Typeset using X $\mathrm{H}^{\mathrm{A}} \mathrm{T} \mathrm{E}$

Cover: Western Scheldt estuary, The Netherlands. Sentinel 2: 2019 false color composite (RGB). Filter from www.instapainting.com

Print: Ridderprint | www.ridderprint.nl

Correspondence to: Muriel Brückner, m.brueckner111@gmail.com

\section{(1) (1)}

Except where otherwise noted, this work is licensed under the Creative Commons Attribution 4.0 International Licence, http://creativecommons.org/licenses/by/4.0/, (c) 2021 by Muriel Brückner.

Chapters 2 to 6 and Appendices are either unpublished submitted articles or final author's versions of previously published articles, () by Muriel Brückner and co-authors. More information and citation suggestions are provided at the beginning of these chapters. 
"Wahrheit an sich ist kostbar, kostbarer aber noch die Fertigkeit, sie zu finden."

Alexander von Humboldt 
$-1$

| | 


\section{Contents}

$\begin{array}{ll}\text { Summary } & 1\end{array}$

Samenvatting $\quad 5$

Zusammenfassung 9

1 Introduction 13

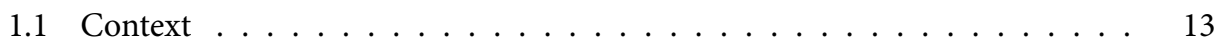

1.2 Painting a picture: Estuaries as large-scale morphodynamic systems . . . . . 15

1.3 Eco-engineers in estuaries . . . . . . . . . . . . . . . 16

1.3.1 Saltmarshes . . . . . . . . . . . . . . . . . . 17

1.3.2 Microphytobenthos \& macrozoobenthos . . . . . . . . . . . . . 19

1.3.3 Ecosystem engineering across scales . . . . . . . . . . . . 20

1.4 Eco-engineering in the Paleozoic . . . . . . . . . . . . . . 21

1.5 Biogeomorphological modeling approaches . . . . . . . . . . . 22

1.6 Research questions and thesis outline . . . . . . . . . . . . . 25

2 Saltmarsh establishment and eco-engineering effects in dynamic estuaries determined by species growth and mortality 29

2.1 Introduction . . . . . . . . . . . . . . . . . . . . . 30

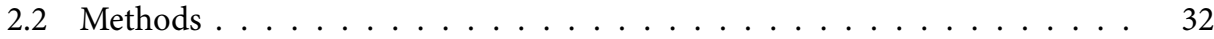

2.2.1 Site description . . . . . . . . . . . . . . 32

2.2.2 The eco-morphodynamic model set-up . . . . . . . . . . . . 35

2.2.3 The dynamic vegetation model . . . . . . . . . . . . . . . 37

2.2 .4 Scenarios . . . . . . . . . . . . . . . . . . . 40

2.3 Results . . . . . . . . . . . . . . . . . . . 41

2.3.1 Vegetation establishment in response to hydro-morphological conditions 41

2.3.2 Eco-engineering effects of the dynamic vegetation . . . . . . . . . 45

2.3.3 Numerical effects and test of upscaling . . . . . . . . . . . . . . 48

2.4 Discussion . . . . . . . . . . . . . . . . . . . . . . . . . 50

2.4.1 Density gradient - plant age and fast-slow colonizers . . . . . . . . . 51

2.4.2 Feedback between eco-engineering effects and salt marsh vegetation . 52

2.4.3 Effects of limitations in the morphological model . . . . . . . . . . . 54

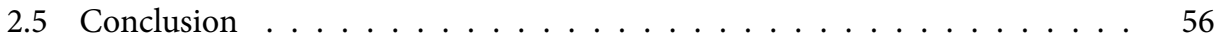


3 What came first, mud or biostabilizers? Elucidating interacting effects in a coupled model of mud, saltmarsh, microphytobenthos, and estuarine morphology $\quad 57$

3.1 Introduction . . . . . . . . . . . . . . . . . . . 58

3.2 Methods . . . . . . . . . . . . . . . . . . . . 60

3.2 .1 Site description $\ldots \ldots \ldots \ldots 6 \ldots \ldots \ldots \ldots \ldots$

3.2.2 Model description . . . . . . . . . . . . . . . . . . 62

3.3 Results . . . . . . . . . . . . . . . . . . . . . . 68

3.3.1 Mud settling and biostabilizers . . . . . . . . . . . . . . . . . . 69

3.3.2 Mud preservation and the role of biostabilization . . . . . . . . . 71

3.3.3 Vegetation effects along the estuarine gradient . . . . . . . . . . 74

3.4 Discussion . . . . . . . . . . . . . . . . . . 77

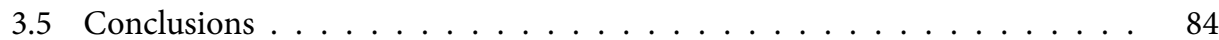

4 On the impact of saltmarsh pioneer species-assemblages on the emergence of $\begin{array}{lr}\text { intertidal channel networks } & 87\end{array}$

4.1 Introduction $\ldots \ldots \ldots \ldots \ldots \ldots$

4.2 Materials and Methods . . . . . . . . . . . . . . . . . . . . 89

4.2.1 Hydro-morphodynamic model . . . . . . . . . . . . . . . . . . 89

4.2.2 Ecological model . . . . . . . . . . . . . . . . . . . 99 91

4.2 .3 Species parameters $\ldots \ldots \ldots 93$

4.2 .4 Scenarios . . . . . . . . . . . . . . . . . . 93

4.2.5 Channel extraction . . . . . . . . . . . . . . . . 95

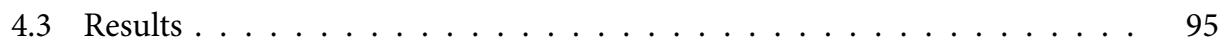

4.3 .1 Single species $(\mathrm{S} 1) \ldots \ldots \ldots$. . . . . . . . . . . . . . 95

4.3.2 Species assemblages $(\mathrm{S} 2) \ldots \ldots \ldots 99$

4.3 .3 Species shifts $(\mathrm{S} 3) \ldots \ldots \ldots \ldots 10 \ldots$

4.4 Discussion . . . . . . . . . . . . . . . . . . . . 103

4.4.1 Single species $(\mathrm{S} 1) \ldots \ldots \ldots$. . . . . . . . . . . . . 103

4.4.2 Species assemblages $(\mathrm{S} 2) \ldots \ldots \ldots \ldots$

4.4 .3 Species shifts $(\mathrm{S} 3) \ldots \ldots \ldots \ldots$

4.5 Conclusions . . . . . . . . . . . . . . . . . . . 106

5 Benthic species as mud patrol - modeled effects of bioturbators and biofilms on $\begin{array}{ll}\text { large-scale estuarine mud and morphology } & 109\end{array}$

5.1 Introduction . . . . . . . . . . . . . . . . . . . . . . . . 110

5.2 Methodology . . . . . . . . . . . . . . . . . . . . . 112

5.2.1 The Western Scheldt domain ． . . . . . . . . . . . . . . . . . . . 113

5.2.2 The idealized hydro-morphodynamic domain . . . . . . . . . . . . . 113 
5.2.3 The macrobenthos computations . . . . . . . . . . . . . . . . . 114

5.2.4 The microphytobenthos computations . . . . . . . . . . . . . . 117

5.2.5 Competition between species and grazing pressure . . . . . . . . . . 118

5.2.6 Model scenarios . . . . . . . . . . . . . . . . . . . . . . . . . . . 118

5.3 Results . . . . . . . . . . . . . . . . . . . . . . . . . . . . . . . 119

5.3.1 Validation of species predictions . . . . . . . . . . . . . . . . . 119

5.3.2 Spatial patterns of species abundance and eco-engineering effects . . . 120

5.4 Discussion . . . . . . . . . . . . . . . . . . . . . . 126

5.4.1 Eco-engineering and species interactions determine species abundance 126

5.4.2 Eco-engineering affects reach-scale morphology . . . . . . . . . . . 128

5.4.3 Eco-engineering affects large-scale morphology . . . . . . . . . . . . . 130

5.4.4 Species shifts affect morphological adaptation . . . . . . . . . . . . 132

5.4.5 Microplastic pollution in estuaries can be mediated by eco-engineers . 132

5.5 Morphology and macrozoobenthic species respond to sea level rise in estuaries 133

5.6 Conclusions . . . . . . . . . . . . . . . . . . . . 136

6 Muddying the waters: Paleozoic land plants caused irreversible changes to estuarine sedimentation

6.1 Paleozoic facies shifts . . . . . . . . . . . . . . . . . . . . . . . . . . . . . 140

6.2 Modeling the sedimentological impact of Paleozoic land plants . . . . . . . 140

6.2 .1 The vegetation stages . . . . . . . . . . . . . . . . . . . . . . 143

6.3 Results . . . . . . . . . . . . . . . . . . . . . . . . . 145

6.3.1 Vegetation evolution affects mud accretion in estuaries . . . . . . . . . 145

6.4 Baffling by vegetation induced a rise in Paleozoic mudrock . . . . . . . . . 146

6.4.1 Flow baffling depends on plant resilience . . . . . . . . . . . . . 146

6.4.2 Ecosystem Engineering on the rise . . . . . . . . . . . . . . . . . . 146

6.4 .3 Vegetation baffling reduces mud bypassing . . . . . . . . . . . . 148

6.5 Conclusions . . . . . . . . . . . . . . . . . . . . . . . . . 148

7 Synthesis: Biogeomorphological models infer new knowledge on the morphological evolution of past, present and future estuaries

7.1 Eco-engineers determine estuarine morphology at the large scale . . . . . . 151

7.1.1 Stabilizing eco-engineers . . . . . . . . . . . . . . . . . . . . 152

7.1.2 Destabilizing eco-engineers . . . . . . . . . . . . . . . . . . 154

7.1.3 Eco-engineering of species communities _ . . . . . . . . . . 155

7.1.4 Eco-engineering effects of saltmarsh, microphytobenthos and macrozoobenthos combined in a model . . . . . . . . . . . . 156

7.1.5 Application of the results to Holocene and Paleozoic estuaries . . . . . 161 
7.2 Interpretations of the results for the response of eco-engineers and morphology with regard to global warming and microplastic pollution . . . . . . . . 163

7.2.1 Shifts in species abundances and effects on estuarine morphology . . . 163

7.2.2 Species shifts can be mitigated through the promotion of biodiversity . 166

7.2.3 Implications of the findings for habitat quality, pollution and microplastic distribution in estuaries . . . . . . . . . . . . . . . 166

7.3 A step forward in parameterizing eco-engineering effects in hydromorphodynamic models . . . . . . . . . . . . . . . . . . . 167

7.3.1 Generic species parametrizations bridge multiple scales in eco-morphodynamic models . . . . . . . . . . . . . . . . . . . . . . 169

7.3.2 New perspectives in biogeomorphological modeling and future recom-

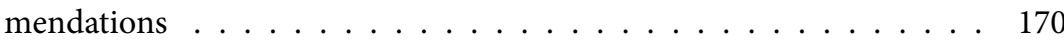

7.4 Conclusions from this work . . . . . . . . . . . . . . . 172

Appendix A Supplementary material for Chapter 2 177

A.1 Additional analysis . . . . . . . . . . . . . . . . . 177

Appendix B Supplementary material for Chapter $3 \quad 181$

$\begin{array}{lll}\text { Appendix C Supplementary material for Chapter 4 } & 183\end{array}$

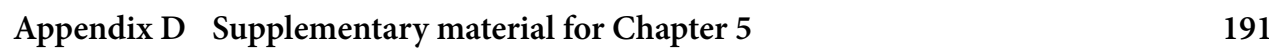

Appendix E Supplementary material for Chapter 6 195

E.1 Mud cover for all scenarios . . . . . . . . . . . . . . . . . . . . 195

E.2 The coupled model . . . . . . . . . . . . . . . . . . . . 195

E.2.1 The hydro-morphodynamic model . . . . . . . . . . . . . . . . 195

E.2.2 Computations of the microbial mats (VS1) _ . . . . . . . . . . . . . . 197

E.2.3 Computations of the vegetation cover (VS2-4) . . . . . . . . . . . . 197

E.2.4 Interactions between the hydro-morphodynamic model and the vegetation code . . . . . . . . . . . . . . . . . . . . 198

$\begin{array}{ll}\text { References } & 201\end{array}$

$\begin{array}{ll}\text { Acknowledgements } & 221\end{array}$

About the author $\quad 223$ 


\section{Summary}

An estuary is a landform that connects rivers with the ocean through an exponentially widening morphology. Estuarine morphology comprises dynamic channel-bar patterns with mudflats and saltmarshes frequently occupying the top of the bars and the fringing shorelines. Its diversity in environments makes the estuary unique and valuable as it provides ecosystem services to humans, comprises a variety of habitats that include feeding-, nursing- and breeding grounds, and hosts a range of rare and protected species that live in distinct niches specific to the system. This complex system affected by a multitude of processes, users and drivers is often vulnerable and threatened, especially due to increasing direct human interference and climatic impacts. To guarantee the functioning and usage of estuaries, careful management is required. In order to inform such a sustainable management, the understanding of how estuarine ecosystems and morphology co-evolve is one crucial prerequisite.

This thesis investigates to what degree the morphology of estuaries is determined by the presence of organisms living in and on top of the sediment: the so-called ecosystem engineers (or eco-engineers). Eco-engineers are organisms able to modify their environment by their physical presence or activity, whereby they modulate resources and facilitate their survival or that of co-existing species. In estuaries, they can be divided into two distinct classes based on their physical effects: biostabilizers and biodestabilizers (i.e. bioturbators). They either stabilize the sediment and possibly promote sediment deposition or destabilize the sediment matrix such that they enhance erosion. At the same time, the environmental conditions, here defined by the hydrodynamics and morphology, determine a species ' habitat and its abundance. As a consequence, eco-engineer abundance and morphology co-evolve and are mutually dependent, creating a feedback loop between species presence and abiotic environment. We require a better understanding of the interactions within this feedback loop to be able to describe and predict estuarine evolution in the past, present and future.

In order to understand and quantify the effect of various eco-engineers on the development of large-scale estuarine morphology, I study the effects of stabilizing microphytobenthos and saltmarsh vegetation and that of destabilizing macrozoobenthic species in a twodimensional process-based model. A sophisticated modeling framework is developed that, based on environmental parameters, predicts species distribution of saltmarsh aboveground plant biomass, presence of microphytobenthos, and macrozoobenthos biomass. Moreover, the model parameterizes species interactions, such as competition and grazing. The speciesdependent eco-engineering effects on the hydro-morphodynamics are incorporated in the model through an added hydraulic roughness and drag or changes in sediment erodibility. The species ' properties and their effects are literature-based and not calibrated, allowing for a wide range of application. This model was first tested in a calibrated hydro-morphodynamic model of the Western Scheldt Estuary and then applied to an idealized estuary with sand and mud to investigate how interactions between sand, mud and eco-engineers affect largescale morphological and sedimentological evolution. At a smaller scale, biogeomorphological processes in tidal channel formation were investigated by modeling three distinct saltmarsh species on an idealized mudflat. The model was expanded towards ancient estuaries 
by simulating stages of land plant evolution in the Paleozoic (between 541-252 million years ago), which allowed me to contribute to the long-standing debate on how evolving land plant traits may have eco-engineered morphology over geological time-scales.

The application to the Western Scheldt Estuary shows that trends in dynamic saltmarsh establishment can be predicted by the eco-morphodynamic model through the implementation of literature-based establishment, growth and mortality rules (Chapter 2). The model reveals that both eco-engineering effects and life-stages that represent aging determine marsh pattern and vegetation density gradients. The development of the dynamic eco-morphodynamic model provides a novel framework for predicting natural patterns of saltmarsh growth in dynamic estuaries and their response to changing external drivers.

The presence of dynamic saltmarsh vegetation and microphytobenthos improves the prediction of mud deposits in the model (Chapter 3). Mud layer thickness and extent are determined by establishment traits of the saltmarsh. The mutual facilitation between both biostabilizers enhances mud cover and species expansion. Moreover, mud settles on bare flats under calm conditions, whereas species growth promotes mud settling in hydrodynamically active areas through alteration of the ratio between flow velocity and inundation period. At the estuary-scale, species-specific saltmarsh pattern affects mud layer formation: a fast expanding species enhances mud thickness while a slowly expanding species increases mud extent.

In addition to these insights from the Western Scheldt Estuary, an idealized mudflat model shows that tidal channel morphology is driven by the eco-engineering of species-specific lifehistory traits (Chapter 4). Computations with all combinations of three common saltmarsh species in northwestern Europe on the idealized mudflat lead to the development of speciesdependent tidal channel networks differing in channel abundance and dimensions. In runs with multiple species, the most abundant species determines the dimensions and stability of the tidal channels, which affect drainage capacity, ebb-dominance and levee formation. A simulation with species shifts shows that projected future biodiversity changes will increase tidal channel erosion and hence the vulnerability of marshes.

Computations of an idealized estuary with two macrozoobenthic destabilizers and microphytobenthos reveals that large-scale morphologies vary depending on the prevailing ecoengineers (Chapter 5). The model with two biodestabilizers sees lateral channel erosion and mud export from the estuary: biodestabilization lowers intertidal bed elevations and mud content and simultaneously increases intertidal area extent. Especially an effective biodestabilizer induces lateral widening of the estuary by promoting the erosion of supratidal areas. In contrast, the presence of microphytobenthos can stabilize the mud, reducing erosion and mud export towards the sea. In simulations with macrozoobenthos and microphytobenthos, a positive feedback on species abundance emerges: individual eco-engineering effects facilitate species expansion of the co-existing species. Consequently, species distributions throughout the estuary differ considerably between single-species and multi-species runs, underlining the importance of eco-engineering and facilitation effects. Sea level rise affects the morphology of the estuary such that mud content is reduced, which promotes lateral channel migration. A mud-prone species disappears from large parts of the estuary as the 
environment becomes sandier, which results in the expansion of a sand-prone species and results in a species shift.

Finally, I explore the effects of distinct stages of Paleozoic land plant evolution on the morphology of estuaries (Chapter 6). The results support the hypothetical link between Paleozoic vegetation evolution and the observed increasing mudrock percentages in the rock record. The model shows that the evolution of plant traits, such as root development, phenotype complexity and increasing resilience against stresses, may have resulted in larger vegetation abundances and, hence, eco-engineering effect. The total volume of preserved mudstone increases coevally with vegetation complexity resulting in regional variations in sediment erosion, transportation and deposition. Until now, it was thought that small-stature rootless plants would have limited morphological effects. However, the modeling shows that aboveground plant parts are able to sufficiently baffle the flow, which concentrates the channels and enhances local mud content. The model suggests that early land plants may have enhanced mud percentages in calm areas of estuaries, whereas the evolution of arborescent vegetation possibly facilitated their establishment along large areas of the estuary and hence increased system-wide mud content.

This work constitutes a significant contribution to our understanding of the morphological evolution of past, present and future estuaries. The large-scale morphology of estuaries is governed by multi-dimensional feedbacks between eco-engineering, species dynamics and morphological response, where (1) individual eco-engineering and species interactions determine species composition and abundance of the ecosystem; (2) the ecoengineering effects by the species community modify morphology depending on species traits and available mud; and (3) the overall morphological response determines habitat and colonization pattern of the species community. Estuaries dominated by biostabilizers evolve stable, muddy and confined morphologies, whereas biodestabilizer-dominated systems widen laterally, are more dynamic and contain less mud. Hereby, the biodestabilizer with the largest eco-engineering intensity determines morphological development, vegetation establishment and ecosystem structure. With regard to future species shifts, we can expect significant responses of estuarine morphologies. This understanding provides new insights for the mitigation of disturbances in estuaries (Chapter 7). In particular, microplastic pollution, habitat degradation or biodiversity loss will alter ecosystem structure and as a result overall morphological evolution. 
$-1$

| | 


\section{Samenvatting}

Een estuarium is een landschapsvorm waarin de rivier met de oceaan verbonden is. Estuaria worden breder toe richting zee, en hebben dynamische patronen van geulen en zandbanken. Slikken en schorren flankeren het estuarium en bedekken vaak de zandbanken. De variatie in condities maken estuaria uniek en waardevol, omdat ze ecosysteemdiensten leveren aan de mens, een verscheidenheid aan habitats omvat, waaronder voeder-, kraam- en broedplaatsen voor vogels, en een reeks zeldzame en beschermde soorten herbergt. Deze complexe systemen worden beïnvloed door een veelheid aan processen, en door gebruikers en beheerders. Ze zijn vaak kwetsbaar en bedreigd, vooral door de toenemende directe menselijke inmenging en klimatologische gevolgen. Zorgvuldig beheer is vereist om de negatieve gevolgen op het functioneren te beperken. Om een dergelijk duurzaam beheer mogelijk te maken, is inzicht in de manier waarop estuariene ecosystemen en morfologie interacteren en ontwikkelen een cruciale voorwaarde.

In dit proefschrift onderzoek ik in hoeverre de morfologie van estuaria bepaald wordt door de aanwezigheid van organismen die in en bovenop het sediment leven: de zogenaamde ecosystem engineers (of bio-bouwers). Bio-bouwers zijn organismen die in staat zijn om hun omgeving te veranderen door hun fysieke aanwezigheid of activiteit, waarbij ze hulpbronnen moduleren en hun overleving of die van naast elkaar bestaande soorten vergemakkelijken. In estuaria kunnen ze worden onderverdeeld in twee verschillende groepen op basis van hun fysische effecten: biostabilisatoren en biodestabilisatoren (ook bioturbators genoemd). De eerste stabiliseren het sediment en bevorderen eventueel de sedimentatie. De tweede destabiliseren de sedimentmatrix zodat ze de erosie bevorderen. Tegelijkertijd bepalen de omgevingscondities, hier gedefinieerd door de hydrodynamiek en de morfologie, de habitat en de aantallen van voorkomen van een soort. De oppervlakte-dichtheid van bio-bouwers en de morfologie ontwikkelen samen en zijn wederzijds afhankelijk, omdat er een terugkoppeling bestaat tussen de aanwezigheid van de soort en het abiotische milieu. We hebben een beter begrip nodig van de interacties binnen deze terugkoppeling om de estuariene evolutie in het verleden, het heden en de toekomst te kunnen begrijpen en te voorspellen.

Om de effecten van verschillende bio-bouwers op de grootschalige ontwikkeling van estuariene morfologie te begrijpen en te kwantificeren, bestudeer ik in het bijzonder de effecten van de stabiliserende microfytobenthos en schorvegetatie en van de destabiliserende macrozoöbenthische soorten in een geavanceerd, tweedimensionaal proces-gebaseerd model. Dit model is ontwikkeld om op basis van fysische variabelen de soortverdeling van de vegetatie, de aanwezigheid van microfytobenthos en de macrozoöbenthos-biomassa te voorspellen. Daarbij parametriseert het model de interacties tussen de soorten, zoals concurrentie en begrazing. Bovendien berekent het model de soortafhankelijke effecten van bio-bouwers op de waterbeweging en morfologische verandering via aanpassingen van de stromingsweerstand en in de erodeerbaarheid van het sediment. De eigenschappen van de soorten en hun effecten zijn gebaseerd op de literatuur en zijn niet gekalibreerd, waardoor een brede toepassing mogelijk is. Dit model werd eerst getest in een gekalibreerd hydromorfodynamisch model van de Westerschelde en vervolgens gebruikt in een geïdealiseerd estuarium met zand en slib om 
de effecten van de soort op de grootschalige morfologische en sedimentologische evolutie te onderzoeken. Op kleinere schaal werden biogeomorfologische processen bij de vorming van getijdengeulen onderzocht door het modelleren van drie verschillende schorplantensoorten op een geïdealiseerd wad. Het model werd uitgebreid naar fossiele estuaria door stadia van de evolutie van landplanten in het Paleozoïcum te simuleren (tussen 541 en 252 miljoen jaar geleden), om bij te dragen aan het debat over hoe de evolutie van de eigenschappen van landplanten en hun bio-bouwer activiteit invloed op de morfologie kunnen hebben.

De toepassing van het model op het Westerschelde-estuarium in vergelijking met karteringen van de afgelopen decennia toont aan dat ruimtelijke trends in vestiging en uitbreiding van schorren goed voorspeld kunnen worden op basis van de literatuurgebaseerde vestigings, groei- en mortaliteitsregels (Hoofdstuk 2). Daarnaast liet het model zien dat de leeftijdsafhankelijke effecten van bio-bouwers het ruimtelijk patroon en de dichtheidsgradienten van de schorvegetatie bepalen. De ontwikkeling van het dynamische eco-morfologische model biedt nieuwe mogelijkheden voor het voorspellen van natuurlijke patronen van schorren en kwelders in dynamische estuaria en hun reactie op veranderende externe factoren.

De aanwezigheid van dynamische schorvegetatie en microfytobenthos verbetert de voorspelling van slibsedimentatie in het model (Hoofdstuk 3). De dikte en de verspreiding van de modderlaag wordt bepaald door de eigenschappen van de plantensoorten. De wederzijdse facilitatie van beide biostabilisatoren verbetert de modderbedekking en de verspreiding van de soorten. Het slib sedimenteert wel op kale oppervlaktes onder rustige omstandigheden, maar de groei van de schorren bevordert het bezinken van het slib in hydrodynamisch actievere gebieden door de veranderingen van de stroomsnelheid en de inundatieperiode. Op de ruimteschaal van het estuarium beïnvloeden soortspecifieke kwelderpatronen de vorming van de sliblaag, waarbij de laagdikte wordt bepaald door snelgroeiende soorten en de verspreiding van de sliblaag door langzaam uitbreidende soorten.

Naast deze inzichten uit de Westerschelde toont een geïdealiseerd wadmodel aan dat het patroon van de getijdengeulen bepaald wordt door de activiteit van bio-bouwers en door hun soort-specifieke kenmerken (Hoofdstuk 4). Berekeningen met alle combinaties van drie gangbare plantensoorten op schorren in Noordwest-Europa leiden tot de ontwikkeling van soortafhankelijke getijdengeulnetwerken die verschillen in de dichtheid en de afmetingen van de geulen. Bij modellering met meerdere soorten bepaalt de meest voorkomende soort de afmetingen en stabiliteit van de getijdengeulen, wat van invloed is op de afvoercapaciteit, eb-dominantie en vorming van oeverwallen. Een simulatie met soortverschuivingen laat zien dat de verwachte toekomstige veranderingen in de biodiversiteit de erosie van de getijdengeulen en daarmee de kwetsbaarheid van natuurlijke schorgebieden zullen vergroten.

Uit berekeningen van een geïdealiseerd estuarium met twee macrozoöbenthische destabilisatoren en het stabiliserende microfytobenthos is gebleken dat de morfologie zichtbaar op grote schaal wordt beïnvloed door bio-bouwer activiteit (Hoofdstuk 5). Het model met twee biodestabilisatoren vertoonde afkalving van de oevers en export van het slib uit het estuarium. Biodestabilisatie veroorzaakt verlaging van de bodemhoogte in de intergetijdegebieden en van het slibgehalte in de waterbodem, en verhoogt tegelijkertijd de omvang van het intergetijdegebied. Met name een effectieve biodestabilisator veroorzaakt een verbreding 
van het estuarium door het bevorderen van de erosie van de supragetijdegebieden. Daarentegen kan de aanwezigheid van microfytobenthos de modder stabiliseren, waardoor de erosie en de export van slib naar zee worden verminderd. Omdat het macrozoöbenthos als het microfytobenthos werden gecombineerd, ontstond er een positieve terugkoppeling tussen het voorkomen van beide soorten: de effecten van beide bio-bouwers vergemakkelijkten de uitbreiding van de andere soorten. Hierdoor ontwikkelen soortengemeenschappen specifieke verspreidingspatronen en morfologische patronen die verschillen van de effecten van een enkele soort. Stijging van de zeespiegel beïnvloedt de morfologie van het estuarium zodanig dat het slibgehalte afneemt en laterale geulmigratie doet toenemen. Een soort die vooral in slibbodems voorkomt, verdwijnt uit grote delen van het estuarium naarmate het milieu zandiger wordt, wat resulteert in de uitbreiding van een zandige soort.

Tot slot heb ik de effecten van verschillende evolutiestadia van paleozoïsche landplanten op de morfologie van de estuaria onderzocht (Hoofdstuk 6). De resultaten ondersteunen het veelvuldig in de literatuur genoemde, hypothetische verband tussen de evolutie van de vegetatie in het Paleozoïcum en de waargenomen toename van de percentages slib in het bewaard gebleven gesteente. Het model toonde aan dat de evolutie van planteneigenschappen, zoals wortelontwikkeling, fenotypecomplexiteit en toenemende veerkracht tegen stress, mogelijk heeft geresulteerd in dichtere en wijder verspreide vegetatie en dus in een groter bio-bouwer effect. Tot nu toe werd gedacht dat kleine wortelloze planten een beperkt morfologisch effect zouden hebben. De modellering toont echter aan dat bovengrondse plantendelen in staat waren om de stroming voldoende te remmen, waardoor de stroming meer in de geulen werd geconcentreerd en het slibgehalte op de platen werd verhoogd. Met de evolutie van de wortels en de toename in plantgrootte werd dit effect versterkt, zodat ook de slibafzettingen toenamen. Het model suggereert dat luwe gebieden van estuaria met vroege landplanten een verhoogd slibgehalte in de bodem hadden, terwijl bomen in staat waren om zich te vestigen op een groter oppervlak van het estuarium en zo het slibgehalte in het hele systeem verhoogden.

Dit werk vergroot ons begrip van de morfologische evolutie van vroegere, huidige en toekomstige estuaria die door organismen worden bewoond. Estuaria die gedomineerd worden door biostabilisatoren ontwikkelen een stabiele en slibbige morfologie, terwijl systemen die gedomineerd worden door destabilisatoren zich lateraal verbreden, dynamischer zijn en minder slib bevatten. Hierbij bepaalt de soort met de grootste bio-bouwerintensiteit de morfologie. De grootschalige morfologie van estuaria wordt bepaald door meervoudige terugkoppelingen tussen bio-bouwers, soortendynamiek en morfologische respons, waarbij (1) individuele bio-bouwereffecten en soortinteracties in het ecosysteem de samenstelling en dichtheid van soorten bepalen; (2) de soortgemeenschap van bio-bouwers de morfologie wijzigen, afhankelijk van de eigenschappen van elke soort en het beschikbare slib; en (3) de algemene morfologische respons de habitats en het verspreidingspatroon van de soortgemeenschap bepaalt. Deze conclusies verschaffen nieuwe inzichten met betrekking tot het beperken van door mensen veroorzaakte verstoringen in estuaria (Hoofdstuk 7). Met name vervuiling met microplastics, achteruitgang van habitatkwaliteit en areaal, soortenverschuivingen of biodiversiteitsverlies veranderen de structuur van het ecosysteem en daarmee ook de estuariene morfologie. 
$-1$

| | 


\section{Zusammenfassung}

Ein Ästuar ist eine Landschaftsform, welche Flüsse mit dem Ozean verbindet und durch eine sich exponentiell ausweitende Morphologie gekennzeichnet ist. Die Morphologie eines Ästuars besteht aus sich abwechselnden Sandbänken und Rinnensystemen, bei welchen die höchsten Sandbänke und die Ufer entlang des Ästuars mit Schlick und Salzwiesen bedeckt sein können. Diese zahlreichen Habitate machen das Ästuar einzigartig und wertvoll, da es Ökosystemleistungen für den Menschen erbringt, eine Vielzahl von Lebensräumen schafft und eine Reihe seltener und geschützter Arten beherbergt. Dieses komplexe System, das von einer Vielzahl von Prozessen und Nutzern beeinflusst wird, ist zunehmend bedroht, insbesondere aufgrund direkter menschlicher Eingriffe und klimatischer Auswirkungen. Um das Funktionieren und die Nutzung unserer Ästuare zu gewährleisten, ist ein sorgfältiges Management erforderlich. Hierfür ist das Verständnis der sich simultan entwickelnden Ökosysteme und der Morphologie des Ästuars eine entscheidende Voraussetzung.

In dieser Dissertation untersuche ich, inwieweit die Morphologie von Ästuaren durch Lebewesen bestimmt wird, die im und auf dem Sediment leben: die so genannten „Ingenieure des Ökosystems“ (oder Eco-engineers). Eco-engineers sind Organismen, die in der Lage sind, ihre Umwelt durch ihre physische Präsenz oder Aktivität zu verändern, indem sie Ressourcen bearbeiten und ihr Überleben oder das Überleben koexistierender Arten erleichtern. In Ästuaren können sie aufgrund ihres physikalischen Effektes in zwei Klassen eingeteilt werden: Biostabilisatoren und Biodestabilisatoren. Sie stabilisieren entweder das Sediment und fördern möglicherweise dessen Ablagerung, oder sie destabilisieren die Sedimentmatrix, sodass sie Erosion hervorrufen. Diese Habitatmodifizierung kann starke Auswirkungen auf die morphologische Entwicklung von Landschaftsformen haben. Gleichzeitig bestimmen die Umweltbedingungen, hier definiert durch die Hydrodynamik und Morphologie, den Lebensraum einer Art und ihre Dichtheit. Infolgedessen entwickeln sich Vorkommen von Eco-engineers und Ästuarmorphologie zusammen und bedingen sich gegenseitig, wodurch ein Rückkopplungseffekt entsteht. Diese Wechselwirkungen erfordern ein besseres Verständnis, um die Ästuarentwicklung in der Vergangenheit, Gegenwart und Zukunft beschreiben und prognostizieren zu können.

Um den Einfluss verschiedener Eco-engineers auf die Entwicklung großräumiger Ästuarmorphologien zu verstehen und quantitativ zu bestimmen, untersuche ich in einem zweidimensionalen, numerischen Modell einerseits die Auswirkungen der Stabilisierung des Mikrophytobenthos und der Salzmarschvegetation sowie andererseits den Effekt der Destabilisierung makrozoobenthischer Arten auf Ästuarmorphologie. Hierfür entwickle ich ein komplexes ökomorphodynamisches Modell, welches auf der Grundlage von Umweltparametern das Vorkommen von Salzwiesen, Mikrophytobenthos und Makrozoobenthos prognostiziert. Darüber hinaus parametrisiert das Modell die Wechselwirkungen zwischen Spezies durch Konkurrenz und Prädation. Auf der anderen Seite berechnet das Modell artenabhängige Auswirkungen auf die Hydromorphodynamik durch hydraulische Rauigkeit und Widerstand oder durch die Änderungen der Erodibilität des Sedimentes. Die Berechnung der Verteilung 
der Spezies und ihrer Auswirkungen sind basiert auf der Literatur und sind nicht kalibriert, sodass eine breite Anwendung des Modells möglich ist.

Zunächst zeigt diese Arbeit, dass Entwicklungen im Salzwiesenwachstum im WesterscheldeÄstuar durch das ökomorphodynamische Modell abhängig von den literaturbasierten Etablierungs-, Wachstums- und Mortalitätsregeln vorhergesagt werden können (Kapitel 2). Sowohl die Auswirkungen ihrer Aktivität, als auch der Alterungsprozess der Vegetation sind hier wichtig, um die Größe der Salzwiesen und die Dichte der Vegetation zu bestimmen. Die Entwicklung des Modells bietet einen neuen Rahmen für die Vorhersage natürlicher Salzwiesen in dynamischen Ästuaren und deren Reaktion auf sich verändernde externe Faktoren.

Das Vorhandensein von Salzwiesen und Mikrophytobenthos im Modell verbessert die Prognose von Schlickablagerungen (Kapitel 3). Die Höhe und die Fläche der Schlickablagerungsschicht wird durch die Eigenschaften der Marschvegetation bestimmt. Positive Wechselwirkungen zwischen Marschvegetation und Mikrophytobenthos fördern die Ausbreitung beider Spezies und vergrößern die Schlickfläche. Im Allgemeinen kann sich Schlick in Bereichen mit wenig Strömungseinflüssen absetzen. An dynamischen Stellen kann bereits etablierte Vegetation die Schlickablagerung erhöhen.

Zusätzlich zu diesen Erkenntnissen aus dem Mündungsgebiet des Westerschelde-Ästuars zeigt ein idealisiertes Salzwiesenmodell, dass die Dichte und Morphologie von Gezeitenkanälen durch artspezifische Merkmale der Vegetation bestimmt wird (Kapitel 4). Das unterschiedliche Wachstum von drei verbreiteten Salzwiesenarten in Nordwesteuropa führt zu Gezeitenkanalnetzen, die sich in Kanalanzahl und -dimension unterscheiden. Diese Netze bestimmen die Stabilität der Kanäle, deren Drainagekapazität und die Größe von Sedimentabsetzungen. Eine Simulation, in der vorkommende Spezies durch neue Arten ersetzt werden, zeigt, dass prognostizierte Veränderungen in der Artenvielfalt von Salzwiesen die Erosion und Form von Gezeitenkanälen beeinflussen.

Berechnungen eines idealisierten Ästuars mit zwei makrozoobenthischen Destabilisatoren und Mikrophytobenthos ergeben, dass großräumige Morphologien durch die Habitatmodifikation der Eco-engineers bestimmt werden: Biodestabilisierung erodiert die Sohle und reduziert den Schlickgehalt des Ästuars, während sich intertidale Gebiete vergrößern (Kapitel 5). Insbesondere ein effizienter Biodestabilisator verursacht die Erosion supratidaler Gebiete, was eine laterale Ausweitung der Morphologie hervorruft. Im Gegensatz dazu kann Mikrophytobenthos den Schlick stabilisieren und Erosion und Sedimentexport in Richtung Meer verringern. Bei einer Kombination von Makrozoobenthos und Mikrophytobenthos entstehen positive Rückkopplungen zwischen den Spezies, da die individuelle Habitatmodifizierung das Vorkommen und die Ausbreitung der Arten positiv beeinflusst. Dies zeigt, dass Artengemeinschaften neue Artenverteilungen entwickeln, die abhängig sind von den individuellen Habitatmodifizierungen und Speziesinteraktionen. Szenarien mit Meeresspiegelanstieg verringern den Schlickgehalt des Ästuars, wodurch sich Artengemeinschaften verändern: eine Art, die Schlick im Bett bevorzugt, verschwindet aus großen Teilen des Ästuars sobald das Bett sandiger wird und wird von einer Art, die Sand bevorzugt, verdrängt.

Das Modell wurde weiterentwickelt, um verschiedene Entwicklungsstadien paläozoischer Landpflanzen auf die Morphologie von Ästuaren zu untersuchen (Kapitel 6). Die Ergebnisse 
zeigten, dass die Evolution von Pflanzenmerkmalen wie Wurzelbildung, Phänotypkomplexität und zunehmende Widerstandsfähigkeit gegen Stress, zu der Ausbreitung von Vegetation und damit zu größeren Eco-Engineering-Effekten führt. Bisher ging man davon aus, dass kleinwüchsige, wurzellose Pflanzen nur begrenzte morphologische Auswirkungen hätten. Die Modellergebnisse zeigen jedoch, dass oberirdische Pflanzenteile in der Lage waren, die Strömung ausreichend zu bremsen, wodurch potentiell die lokalen Schlickgehalte erhöht werden konnten. Mit der Entwicklung von Wurzeln und größerer Widerstandsfähigkeit der Pflanzen verstärkte sich dieser Effekt, sodass systemweite Schlickablagerung ermöglicht wurden.

Diese Arbeit stellt einen bedeutenden Beitrag zu unserem Verständnis von der morphologischen Entwicklung vergangener, gegenwärtiger und zukünftiger Ästuare dar. Ästuare, die durch Biostabilisatoren dominiert werden, entwickeln stabile, schlickhaltige Morphologien, während durch Biodestabilisatoren dominierte Systeme erodieren, sich dadurch aufweiten, dynamischer sind und weniger Schlick binden. Dabei bestimmt die Art mit der stärksten Kapazität zur Habitatmodifizierung die Morphologie und die Struktur des Ökosystems und in welchen Bereichen sich Vegetation etablieren kann. Dieses Verständnis liefert neue Erkenntnisse in Bezug auf die Entschärfung von Störgrössen in Ästuaren (Kapitel 7). Insbesondere Mikroplastikverschmutzung, Habitatdegradation oder der Verlust von Biodiversität verändern die Struktur des Ökosystems und als Folge davon die Anpassung der Ästuarmorphologie. 
$-1$

| | 


\section{Chapter 1}

\section{Introduction}

\subsection{Context}

Estuaries are transitional landforms between the river and the sea. Fairbridge (1980) defines an estuary as "an inlet of the sea reaching into a river valley as far as the upper limit of tidal rise, usually being divisible into three sectors: (i) a marine or lower estuary, in free connection with the open sea; (ii) a middle estuary subject to strong salt and fresh water mixing; and (iii) an upper or fluvial estuary, characterized by fresh water but subject to daily tidal action." Estuaries may form during postglacial sea level rise when glacial and fluvial valleys are flooded by the sea (Dalrymple and Choi, 2007), or by late-Holocene ingression into subsided coastal landscapes (De Haas et al., 2018). With a characteristic salinity gradient ranging from freshwater over brackish to saline waters, estuaries provide unique habitat conditions to a variety of species. Nutrient and sediment supply from the hinterland in combination with dynamic and sheltered conditions that spread along and across the estuary provide favorable conditions for breeding and feeding of numerous aquatic species. As a result, estuarine flora and fauna are extremely rich, making them one of the ecologically most important global environments (Meire et al., 2005; Savenije, 2005).

Today's estuaries are abundant geomorphological features as a result of sea level rise in the Holocene (meaning the past 11,700 years) (Dalrymple et al., 2012; Townend, 2012; De Haas et al., 2018). In the past few thousand years, many estuaries and deltas were populated by humans as they provided rich wetland biota, freshwater supply, and fertile soils (Kennett and Kennett, 2006; Day et al., 2007). Some of these human congregations developed into highly populated cities, such as New York, London, Shanghai, Calcutta, Alexandria or Rotterdam, that are prominent examples of how estuaries face increasing challenges in balancing social, economic and ecological interests. Fisheries, access to harbors and rivers, aquaculture and oyster farming are only some examples of the diverse ecosystem services that estuaries provide (Barbier et al., 2011; De Vriend et al., 2011). Nowadays, the estuary's social and economic role becomes increasingly important in finding a balance between flood safety, human health and pollution, ecosystem functioning, services and diversity (De Groot et al., 2010; Savage et al., 2012; Reed et al., 2018).

In the past centuries, human activity has led to tremendous changes in the physical environment of estuaries and coasts by damming, land reclamation and dredging for navigation or minerals (De Vriend et al., 2011). Moreover, economic growth has introduced waste waters and toxic materials such as heavy metals, pesticides or microplastics to estuarine ecosystems (Bryan and Langston, 1992; Meire et al., 2005; Hitchcock and Mitrovic, 2019). In addition, habitat degradation, water quality deterioration, commercial overharvesting and introduction of new species put increasing strains on ecosystem functioning (Botsford et al., 1997; Kennish, 2002). These challenges will likely become more important with projected future threats induced by global climate change. Not only sea level rise and increasing storm 
frequency will determine the adaptation or loss of estuarine systems, but also changes in hinterland precipitation and rising temperatures will change biodiversity and cause species migration or loss (Day et al., 2013). As a result, we need to understand how the morphological adaption of estuaries and estuarine ecology co-evolve to be able to apply measures mitigating those changes. Increasing flood risk, salinization, land loss, coastal squeeze and ecosystem degradation are alarming trends that we already face today and which likely accelerate in the future.

The morphology of estuaries evolves as a result of both abiotic drivers, meaning hydrodynamic forcing and sediment input, and biotic interactions between the ecosystem and their environment (Allen, 2000; Corenblit et al., 2011). The influence of tides, waves, river discharge and associated sediment supply of marine and riverine sands and muds, the latter representing mixtures of silt and clay, shape the large-scale morphology of estuaries (Corenblit et al., 2007; De Haas et al., 2018). Even though estuaries are strongly driven by abiotic processes compared to biomass-dominated ecosystems, such as tropical forests (Corenblit et al., 2007; Day et al., 2013), the importance of ecology in modulating shape and form of estuaries has been widely acknowledged and hardly investigated. Many studies study the role of ecological drivers on small- or marsh-scale morphologies or analyze simplified representations of biota in morphodynamic models (e.g. Fagherazzi et al., 2012). Moreover, an interactive coupling between biotic and abiotic feedbacks is often neglected but imperative when investigating the morphodynamic evolution of landscapes (Murray et al., 2008), leaving important gaps in our understanding of how biotic effects determine estuarine-scale morphology.

The introduction of the term 'ecosystem engineer' by Jones et al. (1994) led to the new framework of 'biogeomorphology', the study on how biotic processes determine the geomorphological evolution of fluvial landscapes (Corenblit et al., 2011). An ecosystem engineer (or eco-engineer) modulates the availability of resources by inducing physical state changes within an ecosystem such that they 'modify, maintain and create habitat' (Jones et al., 1994). Consequently, individual eco-engineers modify both the evolution of the morphology and the structure of the prevailing ecosystem . Autogenic eco-engineers do so by providing physical structures that indirectly affect the environment. Examples of autogenic eco-engineers in estuaries are microphytobenthos, sea grasses or vegetation. Allogenic eco-engineers directly alter their habitat through their activity by the transformation of materials from one physical state to another. Typical allogenic eco-engineers constitute marine meiofauna, macrobenthic burrowers or zooplankton. However, all habitats on Earth are suggested to be influenced by eco-engineering (for a list of examples see Jones et al. (1994)). This includes ancient Paleozoic landscapes that were likely affected when primitive benthic and vegetation species started colonizing the land.

The aim of this work is to shed light onto the large-scale feedbacks between the ecoengineers and the morphology of entire estuaries. The objective is to enhance our limited understanding of the interactions between various eco-engineers and the abiotic processes that govern estuarine evolution and their mutual effects. The results from this work provide valuable insights on how and why estuaries evolve under the presence of eco-engineers, 
resulting feedbacks onto the ecosystem and possible adaptations of estuaries to changes in future drivers.

\subsection{Painting a picture: Estuaries as large-scale morphodynamic systems}

Tide-dominated alluvial estuaries are often characterized by an exponentially-widening funnelshaped morphology with sandy tidal bars forming between the main tidal channels and a tidal ebb delta developing outside the mouth (Dalrymple and Choi, 2007; Savenije, 2005; Dalrymple et al., 2012; Leuven et al., 2018a) (Figure 1.1). When moving upstream, the river discharge becomes progressively more evident, which leads to narrower and more sinuous tidal channels creating narrow tidal point bars (Dalrymple et al., 2012). The tidal limit, the location where tidal influence ceases, marks the end of the estuary. In nature, estuaries deviate from this ideal funnel-shape as the morphology adapts to external constraints or disturbances, such as sea level rise, antecedent topography and human engineering (Townend, 2012; De Haas et al., 2018; Leuven et al., 2018a; Leuven et al., 2018b). Moreover, the formation of mudflats and alterations induced by marine organisms and vegetation constitute additional drivers that alter the shape of the estuarine morphology (Savenije, 2005; Townend, 2012; Leuven et al., 2018a). For example, when extensive intertidal floodplains, mudflats and saltmarshes form, they can alter the hydro-morphological processes in the estuary and determine its morphological evolution.

Intertidal floodplains are defined by both tidal range and steepness of the slopes of bars and channel banks. Floodplain extent controls the hydrodynamics through provision of accommodation space for the incoming tidal wave. Increasing floodplain area slows down the incoming flood wave as the water can inundate a wider area, but also through local friction on the flow exerted by established vegetation. The emerging tidal asymmetry alters the sediment fluxes from and into the estuary and hence, the large-scale distribution of the sediment (Dronkers, 1986; Friedrichs and Aubrey, 1988; Zhou et al., 2018). Mud (a mixture of silt and clay with a $\mathrm{D}_{50}<63 \mu \mathrm{m}$ ) often settles in intertidal areas, where calm hydrodynamic conditions prevail. Due to its cohesive properties, previously deposited mud will be hardly resuspended, leading to stable sediment layers that protect the sediment from erosion (Van Ledden et al., 2004). Consequently, mud layers inhibit lateral erosion of the estuary and reduce tidal bar and channel migration (Braat et al., 2017; van de Lageweg et al., 2018). In addition to their effects on the hydro-morphodynamics, intertidal floodplains have high ecological significance since they constitute valuable habitats of various species (Day et al., 2013).

Similar as in rivers the infilling of floodplains by mud and vegetation possibly focuses the flow towards the channels and induces channel incision (Tal and Paola, 2007; Tal and Paola, 2010; Van Oorschot et al., 2016; Kleinhans et al., 2018). Potentially, deeper channels and reduced intertidal area affect tidal asymmetry, the propagation of the tides and sediment fluxes. We still lack understanding on how biotic effects alter estuarine morphology and how that feeds back on ebb-flood-dominance and net sediment import or export. Although biogeomorphic feedbacks of saltmarshes, mangroves, biofilms and macrozoobenthos have been investigated at the scale of patches or intertidal flats (Widdows and Brinsley, 2002; Van 


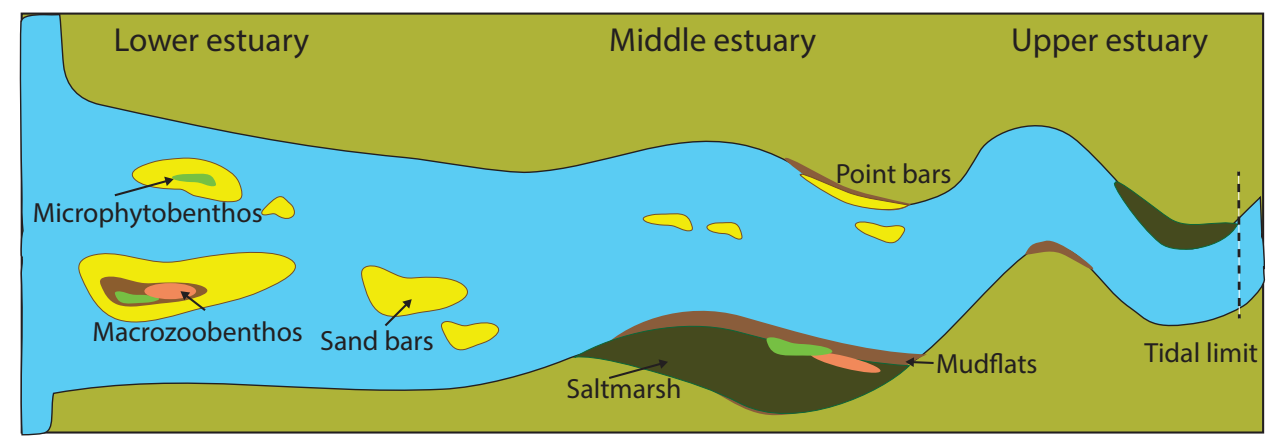

Figure 1.1: Conceptual tide-dominated estuary including typical locations of sandy bars, mudflats, microphytobenthos, macrozoobenthos and saltmarsh. The tidal ebb delta is excluded here.

der Wal et al., 2008; Best et al., 2018; Cozzoli et al., 2019; Xie et al., 2020), the effects of ecoengineers on large-scale estuarine morphology remains poorly studied. In order to understand how eco-engineers alter bed level distribution, mud content and net sediment fluxes, more research on the interacting responses of hydromorphology and ecology is imperative.

\subsection{Eco-engineers in estuaries}

With regard to their effect on hydromorphological processes, two classes of eco-engineers can be distinguished: biostabilizers and biodestabilizers (bioturbators) (for an extensive review see (Le Hir et al., 2007)). Here, stabilization and destabilization refer to the mechanism through which the organism inhibits or promotes erosion of sediments, respectively. Stabilizers are species that protect the sediment against erosion by reducing local flow stress or protecting the sediment directly by their above- or belowground structures. Destabilizers disturb the sediment matrix and facilitate erosion through their motility, meaning their movement while they feed and mate. Destabilization has a specifically large effect on mud when the cohesiveness of the sediment is reduced (Widdows and Brinsley, 2002; Li et al., 2017). The effect of stabilizing and destabilizing eco-engineers on the hydro-morphodynamics is determined by their eco-engineering intensity and the mechanism by which they modulate their environment (autogenic and allogenic eco-engineering).

The intensity by which an eco-engineer stabilizes or destabilizes the sediment depends on its abundance or biomass, and in case of an allogenic eco-engineer its metabolic rate (e.g. Leonard and Luther, 1995; Allen, 2000; Cozzoli et al., 2019). Autogenic eco-engineering intensity (e.g. of vegetation) relates to growth, biomass and habitat of the organism (Chapman, 1964). Biomass increases with growth of the plant from seedling to adult and reproduction by rhizomes or seeds that allow vegetation to expand and form species-specific patches or marshes (Schwarz et al., 2018). Allogenic eco-engineering intensity (e.g. of macrozoobenthos) depends on both biomass and metabolic rate (Brown et al., 2004). The activity of the organisms, meaning their movement and feeding behavior, depends on age and size of the 
individuals, which is determined by complex life-cycles and large spatial and temporal variations in abundance (Cozzoli et al., 2018).

Whether a specific eco-engineer thrives within an area of the estuary is determined by environmental parameters as well as the interactions between species (Bertness and Leonard, 1997; Meire et al., 2005). Habitat suitability increases with decreasing stresses on the species. Abiotic stresses, such as salinity and hydrodynamic pressures, determine species occurrence from mouth to river (Ysebaert et al., 2003; Meire et al., 2005). Likewise, the hydroperiod, resulting from bed elevation distribution and tidal range, determines sub-, inter- and supratidal habitat across the estuary. Particularly in the intertidal area, characterized by alternated flooding by the tides, mudflats and wetlands form that provide feeding, spawning and nursing grounds for a diversity of endangered species including benthos, fish, and birds (Dyer et al., 2000; Townend et al., 2011; Singer et al., 2016; Dissanayake et al., 2018). Biotic stresses, e.g. competition and predation, control ecosystem community in areas subject to low abiotic stresses. As a result, closer to the channels, abundance is determined by environmental stresses, whereas at higher elevations biotic interactions govern species prevalence (Gray, 1992; Day et al., 2013). The combination of abiotic and biotic stresses leads to estuaries characterized by distinct species zonations, both along and across the estuary (e.g. Ysebaert et al., 2002; Morris et al., 2002; van der Wal et al., 2017; Day et al., 2013; Fang et al., 2019).

Species diversity is known to be low in brackish environments and to increase towards the marine and the freshwater realm (Figure 1.2A). In a typical channel cross-section (Figure 1.2B), the supra- and higher intertidal or higher floodplain areas are characterized by emergent vegetation. The more dynamic lower intertidal and subtidal areas, comprise pioneer and submerged vegetation, sea grasses, and biofilms alternating with macrozoobenthic organisms. While biofilms, induced by algae or bacteria, mussel beds and sea grasses stabilize local sediments (Ward et al., 1984; Paterson, 1994) some macrozoobenthic organisms, such as burrowing worms and crabs, are typical biodestabilizers (Le Hir et al., 2007; Cozzoli et al., 2019).

In this thesis, I investigate the morphological impact of two important biostabilizers, saltmarshes and microphytobenthos, and two macrozoobenthic biodestabilizers on estuarine hydromorphology (Fagherazzi et al., 2004; Le Hir et al., 2007; Van der Wal et al., 2008). These eco-engineers are characterized by their eco-engineering function and intensity, specific life-cycles and distinct habitat briefly described below.

\subsubsection{Saltmarshes}

Saltmarshes are the most abundant wetland type and inhabit many estuarine systems (Day et al., 2013). They consist of halophytic or salt-tolerant vegetation species that cover intertidal areas along boreal, temperate and tropical regions (Adam, 1993; Day et al., 2013). The saltmarshes' roots bind and stabilize the local sediment while their above-ground biomass directly reduces flow and wave strength, which promotes sedimentation (e.g. Leonard and Luther, 1995; Allen, 2000). In addition to the enhanced deposition of minerogenic sediments, dense mature saltmarshes increase soil organic matter through root production. These two processes allow them to locally enhance bed elevation and counteract local sea level rise (Kirwan et al., 2016). Moreover, this organic accretion enhances carbon storage in 


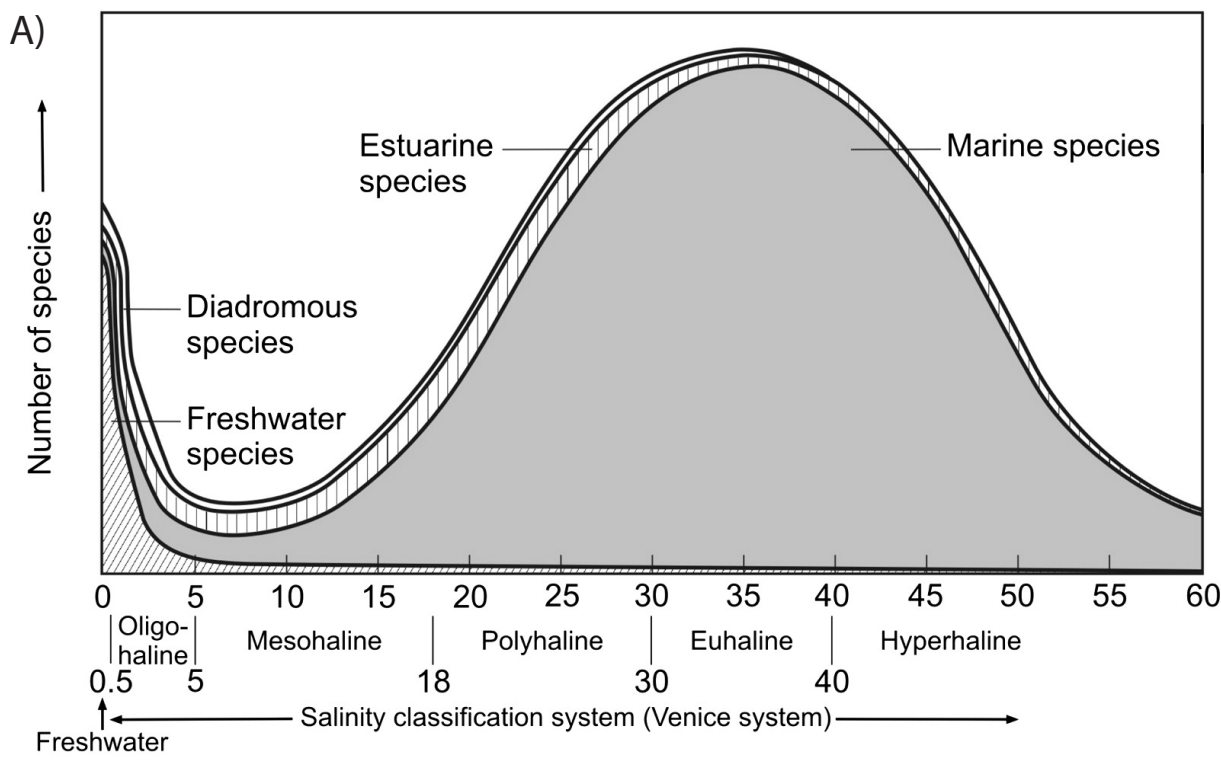

B)

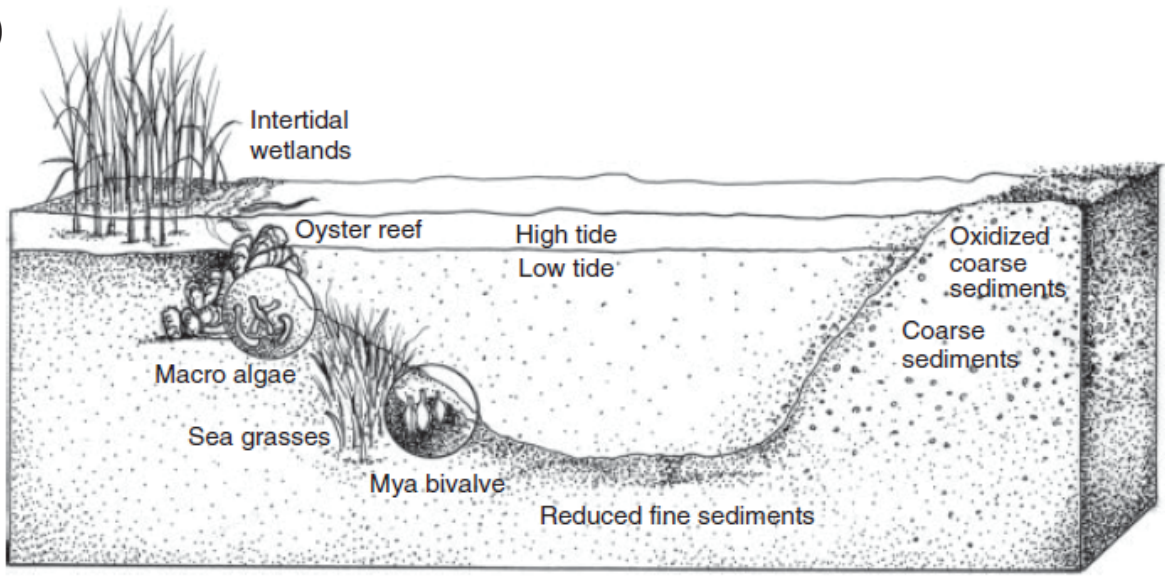

Figure 1.2: A) Species richness along the estuary (Whitfield et al., 2012). B) Typical eco-engineering species grow within an estuarine cross-section (Day et al., 2013). 
marsh sediments, which makes saltmarshes a significant sink for bound atmospheric carbon (Mcleod et al., 2011; Morris et al., 2012).

Saltmarsh vegetation growth is defined at the interface between land and sea at a sensitive equilibrium between local sea level rise, erosion, deposition, and subsidence (Silvestri and Marani, 2004). While pioneer vegetation occupies the lower intertidal areas, successive less stress-tolerant but more competitive saltmarsh species cover higher bed elevations (Pennings and Callaway, 1992; Bertness and Pennings, 2002). Their distribution along the intertidal gradient is defined by physical stresses, such as flow velocities and inundation period, but also temperature, nutrient provision and salinity determine species selection and growth (Allen, 2000). Consequently, plant diversity increases from low to high salt marsh, leading to distinct saltmarsh species productivity and pattern (Adam, 1993). As a result, species dominance and zonation govern eco-engineering effects on flow and turbulence and result in varying depositional patterns of sands and muds (Allen, 2000; Morris, 2006; Silvestri and Marani, 2004).

\subsubsection{Microphytobenthos \& macrozoobenthos}

The benthic zone represents the lowest level of a body of water, including the sediment surface and sub-surface layers, which are occupied by microorganisms and invertebrates (socalled benthos) (Wilson and Fleeger, 2012). Although benthic organisms also occupy subtidal environments, I here focus on species living in intertidal areas. Linked with their large taxonomic and functional diversity, benthic organisms can have contrasting effects on the erodibility of the sediment (Snelgrove, 1998; Le Hir et al., 2007; Van der Wal et al., 2008).

Microphytobenthos forms biofilms on top of muddy sediments by secretion of extracellular polymeric substances (EPS) that stick the sediment grains together (Paterson, 1994; van de Koppel et al., 2001). As a result, they can enhance sediment stability of intertidal flats by up to a factor of five (Le Hir et al., 2007). Sediment stability is reinforced when biofilms grow and expand from spring to summer (Yallop et al., 2000; Le Hir et al., 2007; Van der Wal et al., 2008). Their habitat is defined by sediment properties of the bed and inundation period, but enlarges with increasing temperature, decreasing grazing pressure by macrozoobenthos or shore birds, and reduced wave pressure (Yallop et al., 2000; Friend et al., 2003; Lucas et al., 2003; Mathot et al., 2018).

Macrozoobenthic species are benthic invertebrates that occupy the bottom substrate of rivers, estuaries and the ocean (Wilson and Fleeger, 2012). They come in a variety of sizes from $1 \mathrm{~mm}$ to $20 \mathrm{~cm}$ at present and over one meter in the Late Carboniferous (Heip et al., 1995; Snelgrove, 1998). Common taxa of macrozoobenthic organisms are Polychaeta (worms), Crustacea (shrimps, crabs) and Mollusca (shellfish, snails) that have different functions by which they affect their environment. For instance, mussel beds have the ability to protect the bed from erosive currents and waves, whereas bioturbating species, such as worms, enhance the erodibility of sediments by loosening it through their activities (Widdows et al., 1998b; van Prooijen et al., 2011; Cozzoli et al., 2019). As a result, several speciesspecific mechanisms can lead to modified sediment stability, such as (1) enhanced bottom roughness through biogenic structures; (2) induced particle fluxes through biodeposition and -resuspension or (3) reduced sediment erodibility through bioturbation (Le Hir et al., 
2007). Moreover, macrozoobenthos grazes on biofilms, which leads to a reduction of the effect of microbenthic sediment stabilization (Herman et al., 2001). Despite the species's small sizes, their large abundances and long term activity can have strong effects on the morphological evolution of the intertidal area (Volkenborn et al., 2007; Orvain et al., 2012a) and affect nearshore geology (Widdows and Brinsley, 2002).

\subsubsection{Ecosystem engineering across scales}

The effect of biogeomorphological feedbacks on local and large morphologies depends on a range of temporal and spatial scales and the feedbacks between them (Corenblit et al., 2011; Allen et al., 2014; Schwarz et al., 2015b; Stallins and Corenblit, 2018) (see Figure 1.3). Hydrodynamic time-scales include hourly to daily variations while morphological adaptations can act on much longer time-scales from years to centuries (e.g. Coco et al., 2013). Moreover, eco-engineers modify their environment between hourly to decadal (and in case of forests decennial) time-scales, depending on the species' life-cycle. For example, the mud shrimp C. volutator was shown to be more active during immersion by the tide than at low tide (Lawrie and Raffaelli, 1998). Seasonal microphytobenthos growth stabilizes the sediment on weekly time-scales and vegetation establishment can lead to increasing vegetation densities within years to decades (Allen, 2000; Herman et al., 2001; Friedrichs and Perry, 2001; Van der Wal et al., 2008). Similarly, the spatial scale of eco-engineering ranges from millimeter to kilometer scale. For example, single structures, such as one single plant stem or one burrow hole induce local turbulence that can promote local scour. These small-scale processes do not affect sediment transport and morphology several meters away from the structures. However, if multiple stems form plant patches, intermediate-scale effects on the flow emerge that can lead to large-scale feedbacks with morphology through scale-dependent feedbacks (Schwarz et al., 2015b). Hence, the sum of small- to intermediate-scale feedbacks can promote a system-scale response of the morphology and in turn affects land form evolution (Murray et al., 2002; Erwin, 2008; Corenblit et al., 2011; Coco et al., 2013).

Large-scale morphologies are not only affected by individual eco-engineering but also by the total eco-engineering effect of the estuarine ecosystem. Eco-engineering and ecosystem structure and function are mutually dependent (Corenblit et al., 2011). While ecoengineering can have both positive and negative effects on ecosystems, the net effect on species richness is positive: diverse habitats created by eco-engineers can promote the establishment and growth of a variety of organisms (Jones et al., 1997; Emerson and Kolm, 2005). This niche development is not only supposed to facilitate species richness in modern estuaries but is also thought to be one major driver of species evolution (Jones et al., 1997; Crooks, 2002; Emerson and Kolm, 2005; Corenblit et al., 2011). In addition, species-specific traits and internal ecosystem processes describe ecosystem and biodiversity dynamics. Species-specific traits that include physical properties, growth and mortality, age structure and community properties govern the dynamics of species populations and their abundance (Schwarz et al., 2011; Corenblit et al., 2015; Schwarz et al., 2018). Internal processes, such as facilitation, ecological succession and competition determine which species occupy the available habitat (Corenblit et al., 2011). The evolving ecosystem structure determines biodiversity and niche development. With species niches being engineered habitat patches, they increase ecosystem 


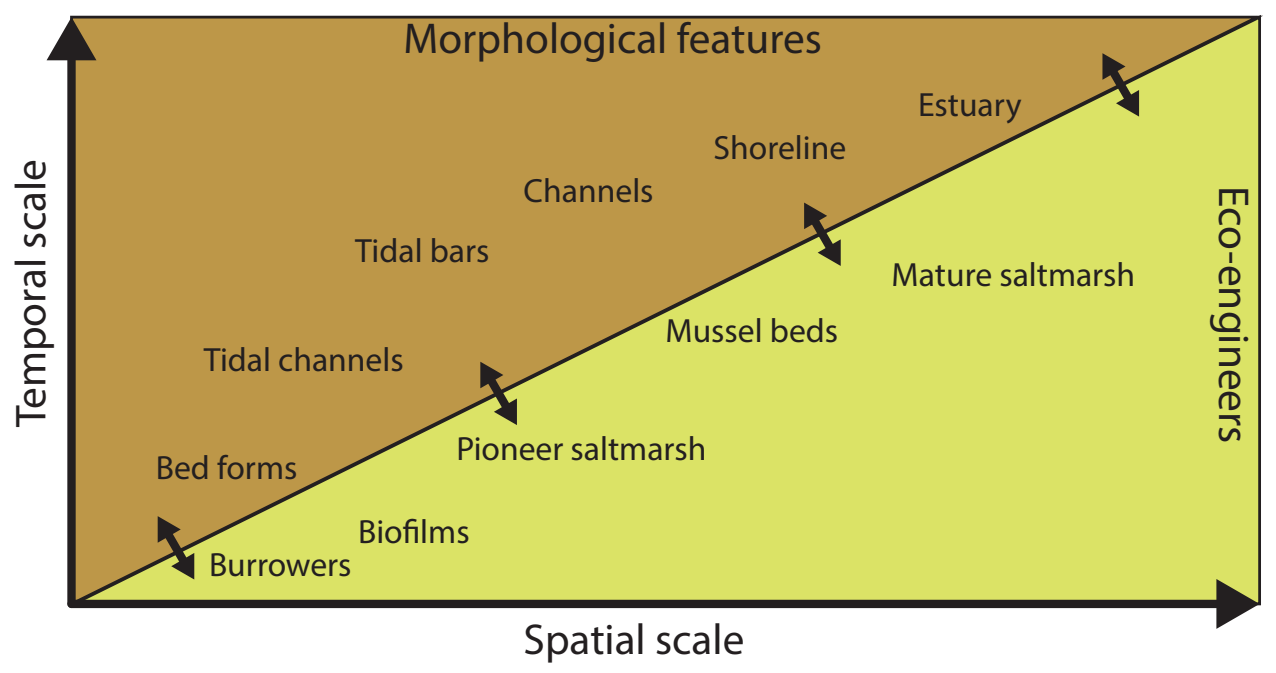

Figure 1.3: Eco-engineers and morphological features in estuaries depending on spatial and temporal scales and their interactions (black arrows).

complexity at the landscape level and govern the evolution of terrestrial, fluvial and marine landforms (Corenblit et al., 2011). Moreover, habitat heterogeneity at different spatial scales is equally important for restoration actions (Vivian-Smith, 2001).

This ecological complexity can be upscaled by investigating functional groups of ecoengineers that are characterized by similar eco-engineering behavior, such as vegetation, biofilms and bioturbators (Cozzoli et al., 2018). Hereby, the concept of choosing a 'key engineer' representing a functional group of eco-engineers is useful. This means that we can generalize eco-engineering of species communities by using a generic species representative for a variety of species with similar functional traits. By selecting the appropriate ecoengineer in an estuary, we can generalize their large-scale eco-engineering effect. Moreover, this assumption allows us to effectively investigate the impact of several co-occurring ecoengineers through several functional groups. As a result, we are equipped with an effective framework to investigate effects of biostabilizers, biodestabilizers and their combination on the morphological development of estuaries.

\subsection{Eco-engineering in the Paleozoic}

Similar to the dynamics in modern estuaries, studies on the geology of the Paleozoic proposed that the colonization of early land plants could have played a role in the geomorphic evolution of ancient landscapes (Schumm, 1968; Davies and Gibling, 2010; Gibling and Davies, 2012; McMahon and Davies, 2018; Pawlik et al., 2020). Land plant evolution involves the development of the first simple ancestral plants descending from green algae in the Late-Ordovician (438-408 Ma) into increasingly complex phenotypes that developed 
roots (early Givetian 38-383 Ma) and seed habit (Late Devonian $360 \mathrm{Ma}$ ) and created extensive forests from the Devonian onwards (Kenrick and Crane, 1997; Sánchez-Baracaldo et al., 2017) (Figure 1.4). Based on fossil evidence, geological studies reconstructed how the earliest plants could have looked like and where they possibly occurred. While the earliest plants are hypothesized to have occupied wet areas close to floodplains, the development of roots allowed them to colonize higher and drier elevations (Meyer-Berthaud et al., 2013; Boyce and Lee, 2017; Lu et al., 2019). Consequently, eco-engineering effects of early land plants were potentially greatest on the morphology of riverine and coastal systems.

As a result, the evolutionary stages marking the development of the above traits possibly led to varying eco-engineering effects and shaped the ancient estuarine landscape. Increasing observations of soil formation and mud rock percentages from the Mid Ordovician onwards indicate that plant evolution has played a major role in the accumulation of fine sediments in terrestrial soils (Davies and Gibling, 2010; McMahon and Davies, 2018). Moreover, the observation of geomorphic features in rivers, such as meandering and anabranching river channels, with increasing vegetation coverages suggest that land plant evolution promoted the development of new landforms (Davies and Gibling, 2010; Gibling and Davies, 2012). Especially the development of roots was hypothesized to have significantly affected plant survival and geomorphic response (Davies and Gibling, 2010). However, most of the research has been carried out in riverine landscapes making estuaries an understudied, yet important, landform that potentially was shaped by the greening of the continents. As the junctions between the land and sea, estuarine morphology and evolutionary vegetation traits co-evolved and are fundamentally linked to a varied range of geochemical cycles, and pass inference on how global silicate weathering patterns may have varied over time.

\subsection{Biogeomorphological modeling approaches}

Numerical modeling is a convenient tool to disentangle interactions between hydro-morphodynamics and ecological processes that are necessary to explain emerging patterns similar to those in nature (Kleinhans, 2010; Fagherazzi et al., 2012; Solari et al., 2016; Wiberg et al., 2020). There exist a range of hydro-morphodynamic models parameterizing ecoengineering species on varying spatial and temporal scales (e.g. Le Hir et al., 2007; Coco et al., 2013; Mariotti and Canestrelli, 2017; Schwarz et al., 2018). However, large-scale morphological effects are usually either simplified in terms of the included sedimentation and erosion formulations or their representation of eco-engineers (Fagherazzi et al., 2012). Besides, due to the complexity of ecosystems, the combination of a variety of functional groups of eco-engineers in large-scale hydro-morphodynamic models has not yet been attempted. Below, I briefly introduce the state of the art of biogeomorphological models and their limitations, why we require more sophisticated ecological representations and what questions we will be able to answer using a novel modeling framework.

To improve our process understanding within large scale morphological systems, we can nowadays work with sophisticated hydro-morphodynamic model packages that solve flow, sediment transport and morphology in two or three dimensions (Fagherazzi et al., 2012; Baar et al., 2019). Some of these models include ecological representations of eco-engineering or 


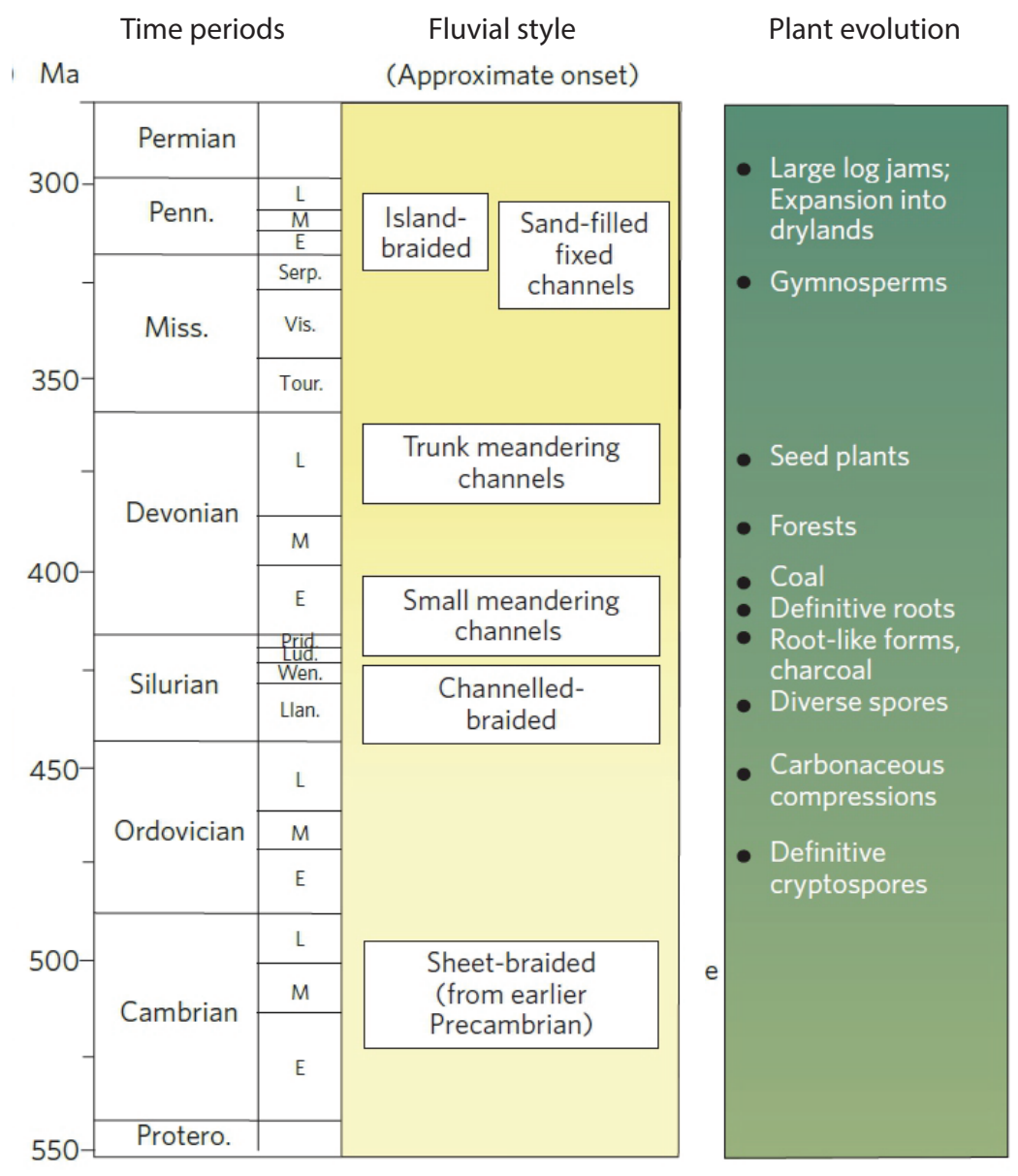

Figure 1.4: Fluvial geomorphic features observed in the geological record along geological time-scales compared to the evolution of land plant traits (adapted from Gibling and Davies (2012) with permission).

species occurrence. Saltmarshes have been subjected to extensive study as they are of high economical value by regulating coastal disturbances and enhancing water and sediment retention (Costanza et al., 1997). However, most existing studies simplified the processes and feedbacks between saltmarsh and hydromorphology (Fagherazzi et al., 2012), sedimentation and erosion processes (e.g. Rodríguez et al., 2017) or coupling between saltmarsh and hydromorphology (Temmerman et al., 2007; Best et al., 2018). Microphytobenthos and macrozoobenthos effects on sediment erosion have been studied extensively in field and flume studies (e.g. Le Hir et al., 2007; Cozzoli et al., 2019). So far, numerical modeling studies have either been restricted to small or medium spatial scales or investigated the effects of one or two key species (e.g. Le Hir et al., 2007; Orvain et al., 2012a; Borsje et al., 2014). As a result, we lack sophisticated large-scale models that capture the effect of benthic eco-engineers and 
their combination with vegetation on the evolution of estuarine morphologies.

In order to investigate eco-engineering effects on the morphological evolution of estuaries, we require model parametrizations that cover the reciprocal interactions between ecoengineering activity, mud distribution and hydro-morphological response (Murray et al., 2008). Moreover, species distributions need to be predicted based on a range of environmental parameters that define their habitat (Silvestri et al., 2005) and species growth and establishment require detailed rules representing seasonality and aging. Such a model has recently been developed for rivers by Van Oorschot et al. (2017), which parametrizes riparian tree establishment, growth, mortality and aging in response to environmental parameters and at the same time computes the eco-engineering effects of the vegetation on the hydromorphodynamic processes.

To understand how eco-engineers contribute to the evolution of estuarine morphology, I developed a novel eco-morphpodynamic model based on Van Oorschot et al. (2017) that can represent the distribution and effect of several eco-engineering species. First, I developed a novel saltmarsh model that accounts for detailed vegetation establishment, growth, mortality as well as eco-engineering effects. The novel model can predict where saltmarshes and its lifestages establish and grow and therefore allows us to study the emergence and disappearance of vegetation under various conditions and drivers. Second, the model was extended to predict the occurrence of micro- and macrozoobenthic organisms and their effect on the erodibility of mud. The dense update between eco-engineers and hydromorphology accounts for instant biogeomorphological responses to changes in abiotic or biotic parameters. In addition, the wide-ranging applicability of the model led to the parameterization of stages of land plant evolution in the Paleozoic. For the first time, this novel eco-morphodynamic model allows the study of a combination of biostabilizers and -destabilizers on large-scale estuarine morphology. Hereby, both the response of the morphology and of the eco-engineering species can be investigated in conjunction. As a result, we are able to study the role of ecoengineering effects and species-specific traits in forming past, present and future estuarine landscapes. 


\subsection{Research questions and thesis outline}

From the knowledge we obtained so far, several specific research questions emerge that will be addressed in the following chapters. An overview of the thesis set-up is illustrated in Figure 1.5.

Starting off with the description and validation of the developed eco-morphodynamic model, Chapter 2 parameterizes saltmarsh vegetation in both a bar-scale and a large-scale morphodynamic model of the Western Scheldt estuary. The chapter quantifies how well saltmarsh is predicted by the model and investigates the following questions about eco-engineering effects:

1. How well can we predict saltmarsh establishment from literature-based rules for establishment, growth, and mortality, and how important are eco-engineering effects for the saltmarsh pattern?

Thereafter, the morphological effect of saltmarsh and microphytobenthos in dynamic estuaries is analyzed, more specifically their impact on mud layer formation. Chapter 3 further elucidates whether mud sedimentation determines saltmarsh establishment, or vice versa.

2. How do saltmarsh and microphytobenthos growth affect mud layer thickness in large-scale estuarine morphologies, and does mud or vegetation occur first?

After investigating large-scale effects of generic saltmarshes, effects of several saltmarsh species on tidal channel formation at the marsh-scale were studied in Chapter 4. Effects of single and multiple species marshes were tested as well as the effect of species shifts to answer the following question:

3. How do saltmarsh species assemblages and associated life-history traits determine tidal channel emergence and what is the effect of species shifts on tidal channel morphology?

In addition to the effects of biostabilizers on morphology, effects of biodestabilizers are investigated in Chapter 5. The impact of two macrobenthic eco-engineers on estuarine morphology is studied and combined with microphytobenthos to shed light on the effects of benthic species communities on morphology, in particular:

4. How do generic macrozoobenthic biodestabilizers, microphytobenthos and their combination affect large-scale estuarine mud distribution and morphology and how is their distribution affected by sea level rise?

Greening of the continents throughout the Paleozoic was accompanied by the evolution of specific plant traits inducing eco-engineering effects that potentially affected estuarine morphology. Chapter 6 elaborates on the question

5. To what extent were evolutionary stages of land plants able to eco-engineer Paleozoic estuaries and determine estuarine mud content and morphology?

To synthesize the findings and put them into context with current and future research, Chapter 7 discusses the outcomes. First, the effects of eco-engineers and communities on the evolution of large-scale morphology are discussed and complemented by additional model results. Second, the insights from the eco-morphodynamic model make it possible to predict how potential species shifts and habitat degradation may influence the future evolution 


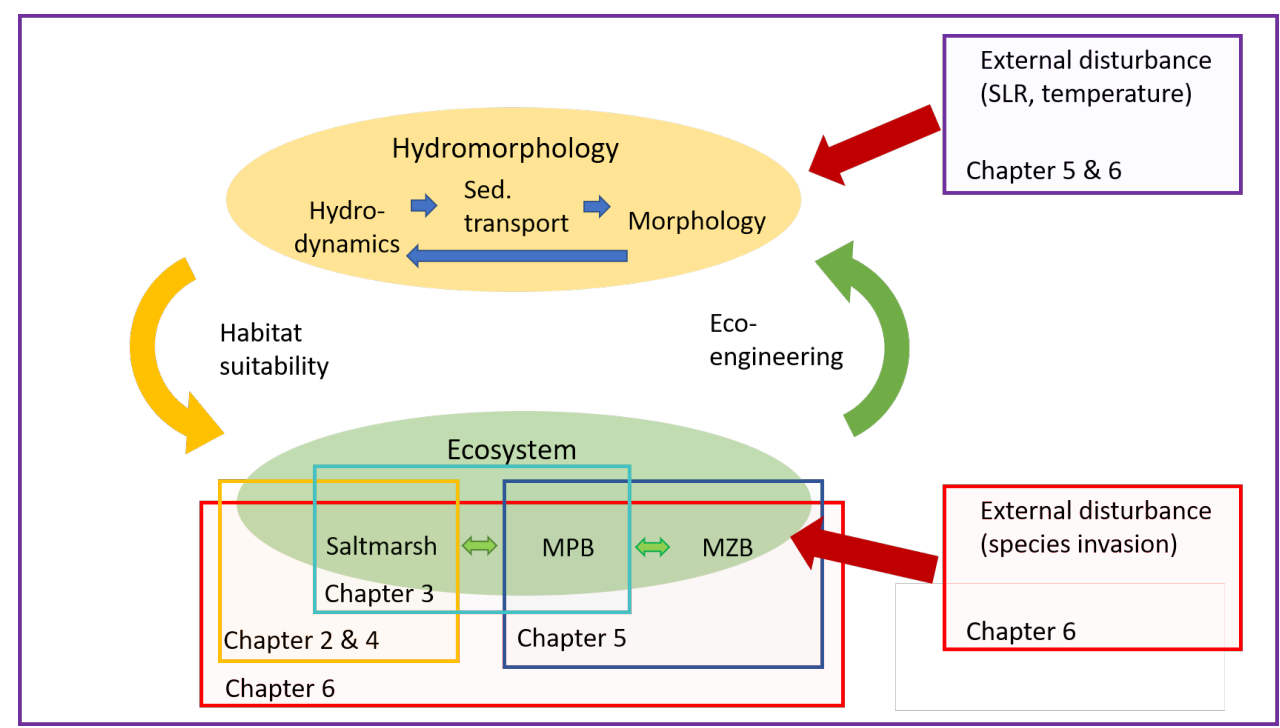

Figure 1.5: Thesis overview with system representation of hydromorphology and ecosystem as the core of this thesis. The colorful squares represent each chapter and the investigated species and processes (MPB: microphytobenthos; MZB: macrozoobenthos; SLR: sea level rise.

of estuarine morphology. Hereby, I conceptualize a potential shift towards biostabilizer- or biodestabilizer-dominated estuaries:

6. How will species shifts towards biostabilizer-or biodestabilizer-dominated systems affect the morphological development of estuaries?

Briefly, I touch upon the increasing threat posed by microplastic pollution in estuaries and the potential feedback loop between microplastic occurrence and eco-engineering effects. Finally, new insights derived from the novel modeling framework are discussed. I conclude with recommendations for future research in the field of biogeomorphology before summarizing the main thesis conclusions. 
$-1$

| | 
$-1$

| | 


\section{Chapter 2}

\section{Saltmarsh establishment and eco-engineering effects in dynamic estu- aries determined by species growth and mortality}

Growth conditions and eco-engineering effects of vegetation on local conditions in coastal environments have been extensively studied. However, interactions between salt marsh settling, growth, and mortality as a function of hydromorphology and eco-engineering lack sufficient understanding to forecast morphological development of dynamic systems. We predict salt marsh establishment with an ecomorphodynamic model that accounts for literature-based seasonal settling and life-stage-dependent growth and mortality of a generic salt marsh species. The model was coupled to a calibrated hydromorphodynamic model of an intertidal bar and, on a coarser grid, to the entire Western Scheldt estuary. To quantify the importance of ecoengineering effects we compared the dynamic model results to a static model approach. The ecomorphodynamic model reproduces spatial pattern, cover, and growth trends over 15 years. The modeled vegetation cover emerges from the combination of a positive and a new negative eco-engineering effect: vegetation reduces tidal flow strength facilitating plant survival while the developing salt marsh increases the hydroperiod, which limits large-scale marsh expansion. The reproduced spatial gradient in vegetation density by our model is strongly correlated to their life-stages, which underlines the importance of age-dependence when modeling vegetation and for predictions of the stability of the marsh. Upscaling of the model to the entire estuary on a coarser grid gives implications for grid size-dependent modeling of hydrodynamics and vegetation. In comparison with static model results, the eco-engineering effects reduce vegetation cover, showing the importance of vegetation dynamics for predictions of salt marsh growth.

Published as: Muriel Z. M. Brückner, Christian Schwarz, Wout M. van Dijk, Mijke van Oorschot, Harke Douma, and Maarten G. Kleinhans (2019), Salt Marsh Establishment and Eco-Engineering Effects in Dynamic Estuaries Determined by Species Growth and Mortality. Journal of Geophysical Research: Earth Surface, 124. https://doi.org/10.1029/2019JF005092 . 


\subsection{Introduction}

Vegetation-landform interactions play a key role in shaping terrestrial-aquatic boundaries in fluvial and coastal environments (e.g. Jones et al., 1994; Temmerman et al., 2005a; Temmerman et al., 2007; Mariotti and Fagherazzi, 2010; Kirwan et al., 2016; Kleinhans et al., 2018; Schwarz et al., 2018). Salt marshes situated along the worlds temperate coasts are prominent examples resulting from vegetation-landform interactions. Their above-ground biomass, such as stems and leaves, reduces flow velocities, dissipates wave energy and promotes sedimentation (Stevenson et al., 1986; Reed, 1990; Leonard and Luther, 1995; Silvestri and Marani, 2004; Morris, 2006; Möller et al., 2014; Kirwan et al., 2016). Increasing rates of sea level rise and increasing vulnerability of populated coastal areas urgently require better understanding of how salt marshes shape coastlines and estuaries (Miller, 1987; Kirwan et al., 2010). This necessitates a better understanding of factors determining salt marsh establishment, growth and mortality.

Salt marshes maximize their chance of survival by adaptation to their environment across different spatial and temporal scales (Holling, 1973; Corenblit et al., 2015). At the scale of patches, physical plant properties, such as stem rigidity, -height, -diameter and -density mainly determine the effects of vegetation on flow and sediment transport through flow resistance. This, in turn, alters the environment for the species, which is called eco-engineering effects (Jones et al., 1994). As flow reduction within patches increases the settlement of suspended particles between plant stems and leaves, an increase in bed elevation through sedimentation of suspended organic and mineral sediments is promoted (Reed, 1990). Since increased elevation reduces inundation stress, these processes were previously referred to as local, or small-scale, positive eco-engineering effects (Bouma et al., 2009a). At the same time, salt marsh plants can facilitate channel formation through erosion between salt marsh patches shaping the drainage network of the entire marsh (Temmerman et al., 2007; Schwarz et al., 2015a) and can lead to large-scale self-organization of the system (Van de Koppel et al., 2012). The necessity to model such systems on the reach scale is also demonstrated for fluvial systems that show similar positive and negative eco-engineering effects, wherein vegetated bars and floodplains affect channels and floodplains over much larger distances than the scale of patches through backwater effects (Van Oorschot et al., 2016; Kleinhans et al., 2018). The intensity of these processes is strongly dependent on the density of the vegetation (Leonard and Luther, 1995; Van Wesenbeeck et al., 2008) and vegetation growth (Bouma et al., 2013). Physical plant properties of salt marshes, located in temperate regions, show seasonal variations in biomass, characterized by seedling germination in spring, peak biomass at the end of summer and senescence in winter (Morris et al., 2002; Ibáñez et al., 2012). With such dynamic vegetation development, the magnitude of eco-engineering effects will not only change through space but also undergo considerable change throughout the growth season and between years.

Before the eco-engineering effects can occur, initial settling and establishment of salt marsh take place. In particular seedling survival requires periods with lower disturbance to allow sufficient root growth to withstand pressures such as currents or waves (Balke et al., 2014; Cao et al., 2018). In general, settling, growth and mortality are species-specific functions 
of environmental conditions and life stage-dependent stress tolerance to inundation, desiccation, flow velocity, scour and burial (Friedrichs and Perry, 2001; Fagherazzi and Sun, 2004; Van Hulzen et al., 2007; Bouma et al., 2013; Schwarz et al., 2018). Seedling survival was shown to be mainly influenced by the combination of burial, erosion and flow velocity (Willemsen et al., 2018; Wang and Temmerman, 2013) while survival of mature plants was shown to be mainly influenced by inundation time expressed in either flooding frequency or hydroperiod (Reed, 1990; Morris and Haskin, 1990; Mendelssohn and Morris, 2002; Morris et al., 2002; D’Alpaos et al., 2006; Hughes et al., 2012; Balke et al., 2016). Inundation time and mature salt marsh development depend on environmental factors such as daily to fortnightly variations in the tide and annual water level variations (Chapman, 1964; Morris et al., 2002; Silvestri and Marani, 2004; Mudd et al., 2004; Suchrow and Jensen, 2010).

Salt marsh response to future changes likely depends on the dynamics of the morphology. In systems with little morphological change on a timescale of decades to centuries, the potential for a salt marsh to keep up with sea level rise depends on fine sediment supply (Kirwan et al., 2010). However, the feedback between vegetation dynamics and eco-engineering response remains poorly understood. While the abiotic properties alone could be used to predict locations where salt marshes will establish, this ignores the feedback between the salt marsh and abiotic stressors, i.e. the eco-engineering effects. Recent research conducted in the Western Scheldt estuary, the Netherlands, showed that the border between the high biomass high marsh and low biomass pioneers zone can be found at a relative inundation period of around 0.45, which was shown to be applicable to Dutch as well as to North American salt marshes (Van Belzen et al., 2017). This empirical threshold is not only the result of the individual plant properties, but also of the modifications of the abiotic conditions by the salt marsh. In other words, the survival of plants depends on abiotic spatial and temporal variables (i.e. water levels, sediment supply, salinity) that in turn are affected by vegetation distribution and collective plant characteristics of the life-stages of all species present (Cowles, 1911; Bouma et al., 2005; Wang and Temmerman, 2013). We aim to disentangle the interaction between vegetation establishment, growth, mortality on the one hand and of specific eco-engineering effects on salt marsh establishment on the other hand. In particular, we study a dynamic estuarine environment where salt marsh established only recently and conditions are well-described. This will contribute to a better understanding and systemscale predictability of initial colonization of pioneer vegetation on bare tidal flats and for managed realignment projects.

To address this objective, a numerical model is needed that incorporates the above-mentioned interactions between flow, morphology and vegetation over time and space, further referred to as eco-morphodynamic model. Past work addressed only part of the processes and feedbacks; for instance some models consider vegetation flow interactions but model spatial vegetation establishment as constant vegetation biomass determined by tidal benchmarks, such as inundation period or bed elevation (e.g. Mudd et al., 2004; D’Alpaos et al., 2006; D’Alpaos et al., 2007; Marani et al., 2010; D’Alpaos, 2011), further referred to as static establishment approach. Others include detailed interactions between vegetation flow and inundation time but oversimplified vegetation-induced sedimentation and erosion (e.g. Rodríguez et al., 2017). In long-term modeling, growth and seasonality are usually simplified, 
where the salt marsh development is updated yearly or quarterly (e.g. Temmerman et al., 2007; Rodríguez et al., 2017; Best et al., 2018), or a factor is introduced accounting for reduced biomass in winter (Mudd et al., 2004; Best et al., 2018). Simplified bathymetries, hydrodynamics and sediment transport computations limit the development of natural vegetation response in all these models and the adaptation of the plants resilience with aging from seedling to mature life-stages has not been accounted for in any eco-morphodynamic model so far.

Here we apply a new eco-morphodynamic model framework, able to simulate spatiotemporal salt marsh development based on detailed interactions with hydrodynamics, sediment transport, field morphology and -forcings. Vegetation parameters, e.g. growth and mortality, are literature-based, season-dependent and age-, or life stage-dependent, which will allow local and far-field eco-engineering effects to emerge from frequent coupling to the hydro-morphodynamics. We test the ability of this new eco-morphodynamic model to predict salt marsh development on both an intertidal bar and on the entire Western Scheldt estuary, for which detailed field data for validation are available.

\subsection{Methods}

To determine the main processes that govern salt marsh establishment in dynamic systems we investigated an intertidal bar, located in the Dutch part of the Western Scheldt estuary, south-west of the Netherlands, as a reference case. For the Western Scheldt, a wide range of monitoring data (bed elevations and vegetation distribution) are available, allowing validation of model results for several years of salt marsh establishment and growth including the feedbacks with the morphological development.

We developed a new eco-morphodynamic model consisting of a dynamic vegetation model which is coupled with a hydro-morphodynamic model (HM-model). The dynamic vegetation model was originally developed by Van Oorschot et al. (2017), as a dynamic model for riparian trees and herbs. Here we extended the dynamic vegetation model for generic salt marsh growth and mortality for two life-stages and implemented a coupling interval with the HM-model every tidal cycle of the dominant M2-tide. Every coupling the hydromorphodynamic calculations were used as input for the dynamic vegetation model, which updated the spatial vegetation distribution. The new vegetation distribution was fed back into the HM-model as a hydraulic roughness and an extra drag term. As a result, we captured the feedback-loop between vegetation dynamics and morphology on dense temporal scales that allowed for a detailed study of the co-occurring processes.

\subsubsection{Site description}

The investigated intertidal flat is a $4 \mathrm{~km}$ long bar located in the $160 \mathrm{~km}$ long Western Scheldt estuary, the Netherlands (Figure 2.1). The dynamic tidal bar of Walsoorden experienced recent salt marsh establishment starting from the 1990's and has been intensively studied for understanding its bed form patterns, morphological, habitat and salt marsh development and macrobenthic dynamics (Van der Wal et al., 2008; Plancke et al., 2010; Van der Wal et al., 2011; Van der Wal and Herman, 2012; Cleveringa, 2014; De Vet et al., 2017). 


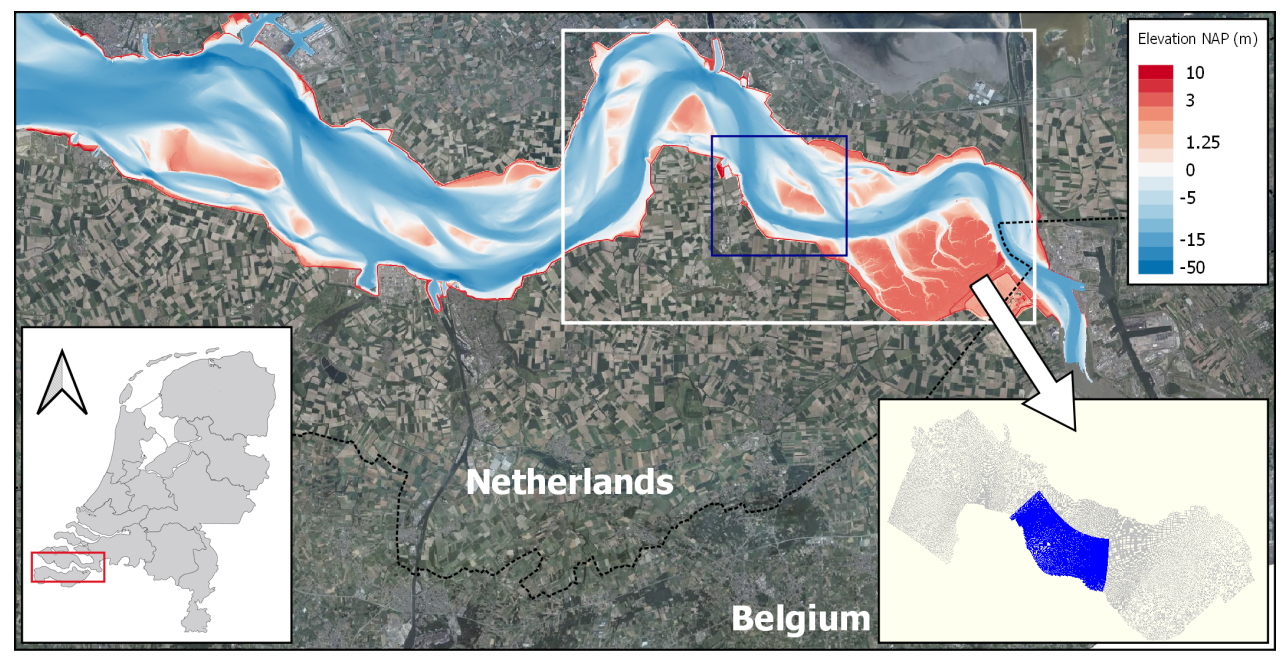

Figure 2.1: Location of the tidal bar of Walsoorden in the Western Scheldt estuary located in the south-west of the Netherlands. The numerical grid is decomposed into two domains to increase numerical efficiency. The white rectangle outlines the coarser outer grid and the blue rectangle outlines the bar of Walsoorden covered by a finer grid.

The Western Scheldt estuary is a tide-dominated, meso- to macro-tidal estuary with an upstream increasing tidal range from $3.8 \mathrm{~m}$ at the mouth to $5.2 \mathrm{~m}$ near the city of Antwerp (Meire et al., 2005). The importance of wave forcing on morphology is gradually exceeded by the effects of tidal currents from the mouth towards the meso-haline part of the estuary $(\mathrm{Hu}$ et al., 2018). The estuary has been impacted by dredging and dumping since the 1970's (Van Damme et al., 1999). The dredging activity in combination with local sea level rise is thought to have caused higher bars and steeper bar margins and caused the intertidal zone in the estuary to constantly decrease in dimensions (De Vriend et al., 2011; van Dijk et al., 2019a). The marshes in the Western Scheldt persisted because of their fast adaptation to changes in the hydrological regime (Van Damme et al., 2001; Temmerman et al., 2005b; Wang and Temmerman, 2013). The salt marshes are dominated by the pioneer species Spartina anglica and Salicornia ssp.. At later succession stages Aster tripolium and in brackish salt marshes Scirpus maritimus are becoming dominant (De Vriend et al., 2011).

The study site, the tidal bar of Walsoorden, is located in the meso-haline part of the estuary around $50 \mathrm{~km}$ land inwards from the mouth between an ebb and flood channel of the Western Scheldt estuary (Figure 2.1). It consists mainly of sandy sediments of 50-150 $\mu \mathrm{m}$ with less than $10 \%$ mud content (Van Eck, 1999). Ecotope maps were collected on a multi-annual basis to monitor locations of salt marshes (between high water and spring tide), bare tidal flats (between low and high water), and open water (shallow and deep) based on aerial imagery and relative bed elevation (Van Damme et al., 2001). For our analysis and comparison to the model results we simplified our map to the relevant morphological classes present in the ecotope maps (Figure 2.2), which are bare soil (with one class for sediments classified as 


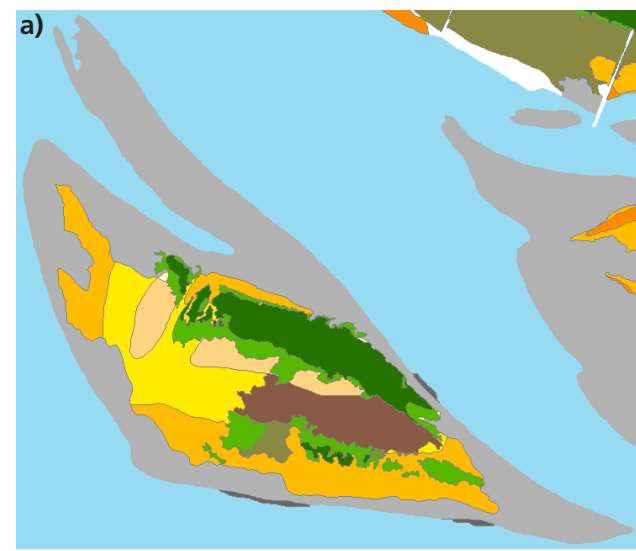

low-dynamic soft substrate in shallow sublittoral high-dynamic fine sand littoral

high-dynamic soft sediment

low-dynamic fine sand low littoral

low-dynamic fine sand middle littoral

low-dynamic fine sand high littoral

low-dynamic soft sediment supralittoral

high-dynamic soft sediment supralittoral

low-dynamic muddy middle littoral

low-dynamic muddy high littoral

sparse pioneer vegetation

dense salt marsh

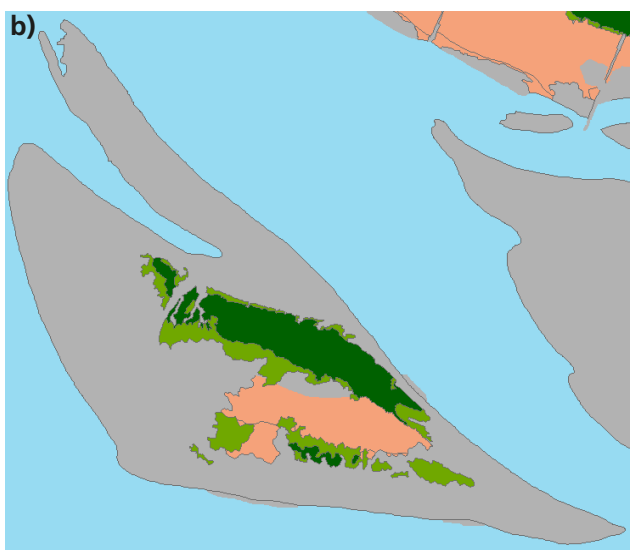

Open water

mud

sand

sparse vegetation

dense vegetation

Figure 2.2: Ecotopes of the bar of Walsoorden of 2010 mapped by the Dutch Water Authorities. In (a) the original morphological classes are displayed with a distinction between high- and low-energetic environments, littoral classes along bed elevation, and salt marsh cover. Based on these classes we determine classes that included either vegetation or bare soil with bare soil being further classified by sediment type into either muddy sediments or sandy sediments (b). For our analysis we compare our results to (b).

muddy), "sparse/pioneer" vegetation and "dense/mature" vegetation distinguished by high and low coverage (dense: $>50 \%$ and sparse: $<50 \%$ ).

In 1996, patches of the pioneer species Spartina anglica and Salicornia ssp. were observed for the first time by Stikvoort (1996) and over time led to the development of a mature salt marsh on the bar of Walsoorden (Cleveringa, 2014). The strongest increase in pioneer vegetation occurred between 2004 and 2008, which coincides with reduced high water levels between 2001 and 2005 (Balke et al., 2014). At the same time, dredging and dumping were started nourishing the area around the bar with little effect on ecology (Van Der Wal et al., 2005; Ides et al., 2007; Van der Wal et al., 2008; Van der Wal et al., 2011). Overall, a steepening of the bar margins with an increase in average bed elevation since 2001 was observed (Cleveringa, 2014; De Vet et al., 2017). This combined development of bed accretion and increase in vegetation cover gives the opportunity to gain insights into the factors that control successful salt marsh establishment of pioneer species characteristic for NW-Europe. 


\subsubsection{The eco-morphodynamic model set-up}

Our dynamic vegetation model was coupled to a depth-averaged two-dimensional hydromorphological model in Delft3D (version 4.01.00), a code that solves the shallow water equations (Lesser et al., 2004; van Dijk et al., 2019b). As sediment transport predictor we used Van Rijn (2004) as implemented in Delft3D (van Dijk et al., 2019b). The morphodynamics are included by solving the advection-diffusion equation for suspended sediment based on reference concentration and capacity transport for bed load combined with mass conservation (see Lesser et al. (2004) for more detail). The interaction between vegetation and flow is realized by the existing trachytope module in Delft3D, which calculates an average flow resistance in each grid cell from the present fractions of vegetation, and their properties, based on the Baptist-equation (Baptist et al., 2007).

The sub-domain of the hydro-morphodynamic (HM) model is taken from a model of the Western Scheldt (Nederlands-Vlaams (NeVla) or Dutch-Flemish model) that was implemented in Delft3D, hydrodynamically calibrated (Maximova et al., 2009b; Maximova et al., 2009a; Vroom et al., 2015) and later optimized for morphology (Grasmeijer et al., 2013; Schrijvershof and Vroom, 2016). For investigating the intertidal bar at a higher grid resolution, the hydro-morphodynamic domain was decomposed into two domains to reduce computational time while allowing for accurate hydrodynamic and vegetation computations. The outer domain comprises of grid cell size up to $180 \mathrm{~m}$. We applied the vegetation modeling on the area of interest on a refined inner grid (down to $16 \mathrm{~m}$ cell size) that covers the entire shoal and partly the adjacent channels (see Figure 2.1). Our hydrodynamic time-step was $6 \mathrm{~s}$ to allow for stable simulations. To test the possibility for upscaling we also used the original coarser, computationally cheaper, NeVla-model grid for the region from the mouth to the Dutch-Belgian border (see blue-red area in Figure 2.1).

The boundary conditions of the outer domain were time-series of seaward water level measurements and landward discharge measurements in the Western Scheldt in 2013 (van Dijk et al., 2019b). Consequently, most tidal constituents, wind and wave surges, and seasonal discharge variations were captured in the boundaries. However, waves were not solved in the model as the Western Scheldt is a tide-dominated system (Davis Jr and Hayes, 1984) and a small fetch leads to limited wave effects on the tidal bars (Hu et al., 2018). To solve the problem of fitting the tidal period in an integer number of days (Duran-Matute and Gerkema, 2015), we compressed the period of the dominant M2-tide to 12 hours, which led to a reduced forcing period of each water level by $3 \%$. That way we were able to couple our vegetation model each tidal signal, leading to an ecological time-step (ETS) of 12 hours of hydrodynamics. This step was an important prerequisite to provide continuous forcing for each vegetation computation that included the entire variation along one M2-tide and at the same time allowed to upscale the model to morphological time-scales.

From the boundaries we chose four representative spring-neap cycles (i.e. MHW, MW and MLW are in the same range as for the entire year) that we upscaled to four morphological years using a morphological acceleration factor of 24. The morphological acceleration factor multiplies the morphological computations by a factor to accelerate morphological development compared to the hydrodynamic forcing (Lesser et al., 2004). As a result, we 
assume that one tidal signal (here now 12 hours) roughly represents one spring-neap cycle in morphological time (12 days). We apply 28 tidal signals per morphological year to fit the water levels of an entire spring-neap cycle into each year (14 days of hydrodynamic boundaries). Consequently, one morphological year is represented by one spring-neap cycle of hydrodynamic boundaries. As morphological and ecological time were directly coupled, this resulted in 28 vegetation updates each morphological year. The four spring-neap cycles led into four morphological, or ecological, years for each scenario with a total simulation time of 56 days of hydrodynamic boundaries. For our longer calculations we repeated the prescribed boundary conditions and ran 15 morphological years, which was similar to the period for which field data were available.

The hydrodynamic model computes water levels and flow velocities through mass and momentum conservation. With each ecological update, the settlement locations and surface fractions of the vegetation and the physical properties (height, stem diameter, density) were fed back into the HM-model. All life-stages in a grid cell were combined into a single Chézy coefficient $C$ for each cell and used for the calculation of an additional drag term $\frac{\lambda}{2} u^{2}\left[\mathrm{~m} / \mathrm{s}^{2}\right]$ in the momentum equation:

$$
\frac{\delta u}{\delta t}+u \frac{\delta u}{\delta x}=-g \frac{\delta \eta}{\delta x}+v \frac{\delta^{2} u}{\delta x^{2}}-g \frac{u|u|}{C^{2} h}-\frac{\lambda}{2} u^{2}
$$

$\lambda[1 / m]$ is calculated based on the relative change in velocity, which depends on the water depth $h[m]$, vegetation height $h_{v}[m]$ and net bed roughness $C[\sqrt{m} / s]$ :

$$
\lambda=\left\{\begin{array}{l}
C_{D} n \frac{h_{v}}{h} \frac{C_{b}^{2}}{C^{2}}, \text { if } \mathrm{h} \geq h_{v} \\
C_{D} n, \text { if } \mathrm{h}<h_{v}
\end{array}\right.
$$

where $C_{b}[\sqrt{m} / s]$ is real bed roughness, $C_{D}$ [-] the bulk drag coefficient accounting for leaves and branches of the plant, and $n\left[\mathrm{~m} / \mathrm{m}^{2}\right]$ plant density multiplied by stem diameter. $C$ is defined for the case of emerged or submerged vegetation as

$$
\mathrm{C}=\left\{\begin{array}{l}
C_{b}+\frac{\sqrt{g}}{\kappa} \ln \left(\frac{h}{h_{v}}\right) \sqrt{1+\frac{C_{D} n h_{v} C_{b}^{2}}{2 g}}, \text { if } \mathrm{h} \geq h_{v} \\
C_{b}, \text { if } \mathrm{h}<h_{v}
\end{array}\right.
$$

with $g=9.81\left[\mathrm{~kg} / \mathrm{m}^{2}\right]$ gravity and $\kappa=0.41[-]$ von-Kármán constant. For simplicity we chose 1 and 1.1 for $C_{D}$ for juveniles and mature life-stage, respectively, approximating the plants as smooth rigid cylinders (Baptist et al., 2007). From equations 2.2 and 2.3 it is obvious that the seasonal changes of plant height and stem diameter allow for a detailed temporal and spatial representation of the vegetation growth that to-date has not been included in numerical modeling of salt marsh vegetation. 
To compute the total vegetation effect in each cell, both $C$ and $\lambda$ are weighted by the fraction of the cell that is covered by the vegetation. For the computation of several vegetation fractions within one cell the average weighted values are computed as

$$
C_{\text {total }}=\sum_{i} f_{i} C_{i}
$$

and

$$
\lambda_{\text {total }}=\sum_{i} f_{i} \lambda_{i}
$$

where $f_{i}$ is the according vegetation fraction.

Equation 2.3 has been derived for plants that cover a significant cross-section of the water column that allows for a constant velocity field within the vegetation. This requirement allows for a straightforward separation into one part of the flow parameterized by the vegetation and the logarithmic profile above the vegetation in case of submerged vegetation. Our salt marsh vegetation has a minimum stem height of $10 \mathrm{~cm}$, which fulfils this requirement. Moreover, flexible and leafy vegetation properties can only partly be captured by the bulk drag coefficient. Through the computed drag term in the momentum equation, the vegetation properties have a direct effect on the computations of flow velocity, sediment transport, and morphology.

\subsubsection{The dynamic vegetation model}

Our dynamic vegetation model consists of different vegetation modules divided into colonization, growth and mortality that parametrize a dynamic, i.e. temporally and spatially varying, generic salt marsh species by several literature-based vegetation rules (Figure 2.3). The interacting processes cause a temporal-physical plant variation by growth and temporalspatial dynamics induced by mortality. The dynamic vegetation model is based on the riparian vegetation model of Van Oorschot et al. (2017) but the intra-annual salt marsh growth and treatment of the periodic tides is novel, as previous studies simplified the hydro-morphodynamic stresses by the periodic tides (Lokhorst et al., 2018; Kleinhans et al., 2018).

\section{Colonization, growth, and aging}

Seedling establishment occurs at the second ecological time-step of each ecological year. The spatial distribution of the seedlings is based on the mean of the computed water levels in the HM-model for the precedent ecological time-step. A cell was defined as flooded when the water depth within one ETS surpassed $0.02 \mathrm{~m}$ to account for soil saturation and evapotranspiration (Hughes et al., 2001; Miller and Zedler, 2003). The cells that were flooded and subsequently dried again are determined as locations where seeds establish. This method is based on the assumption that seeds are dispersed by the tide, which is the main reproduction strategy of fast-colonizing pioneer marsh vegetation such as Spartina anglica and Salicornia ssp. (Schwarz et al., 2018). The vegetation is assigned to the cells by the means of an initial fraction of a maximum density for pioneer salt marsh that was typically found in literature (Table 2.1).

We assume a generic perennial pioneer species, based on Spartina anglica and Salicornia ssp., 


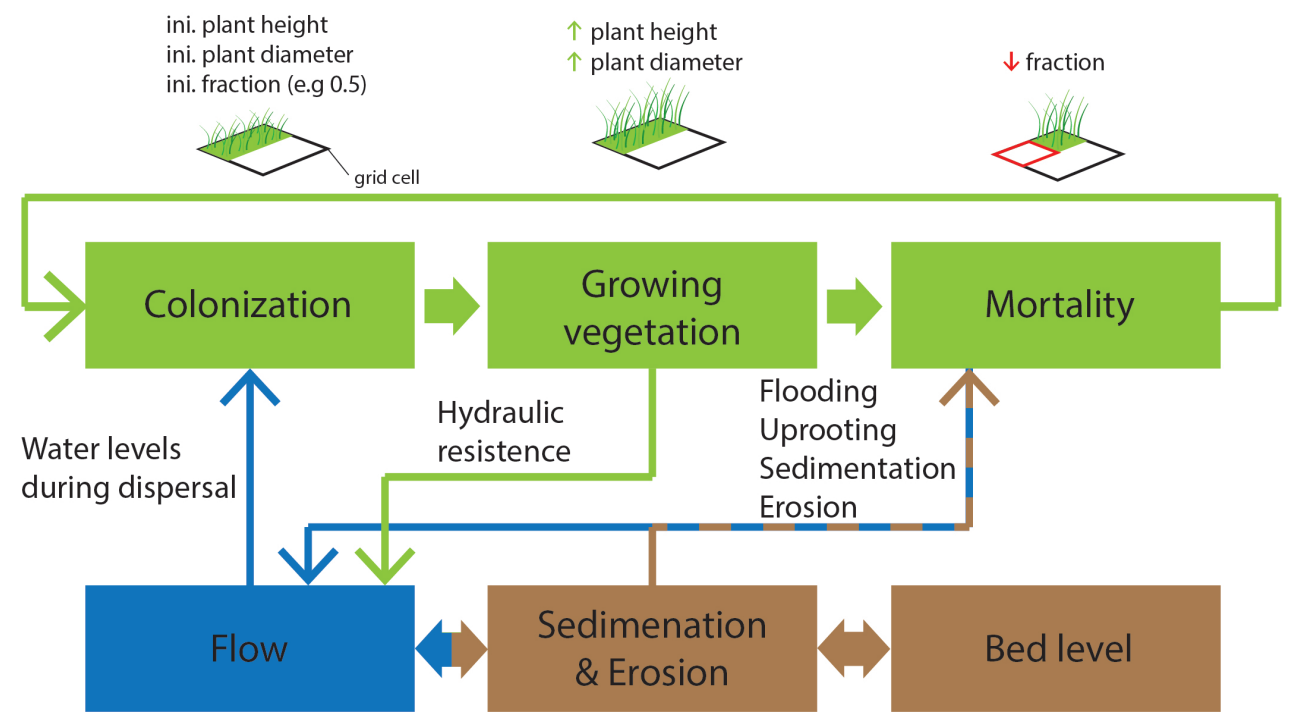

Figure 2.3: Overview of the feedback mechanisms in the eco-morphodynamic model. Colonization settles plants with an initial vegetation fraction, height and diameter. With time the plant size increases while the fraction of each plant covering the grid cell will be reduced by the mortality. The total vegetation resistance follows from averaging the plant cover in each cell. The arrows indicate a direct transfer of information between the vegetation and the hydro-morphodynamic computations. Indirectly, all processes affect each other through the feedbacks between modification of the entire flow field and morphological development.

whose underground biomass survives in winter and regrows in the subsequent year. Tussock and patch formation smaller than the grid resolution was ignored here. The physical plant properties of the modeled salt marsh vegetation are determined by its growth function which incorporates seasonal plant dynamics (Ibañez et al., 1999). Seasonal dynamics are expressed in the variables that change within one or several years of plant growth, i.e. shoot height, root length and stem diameter (see Table 2.1). The vegetation settles in the beginning of the growth season (at time $t_{1}$ ) and grows linearly with time to a maximum height and stem diameter (at time $t_{2}$ ). Between $t_{2}$ until the end of the growth season (at time $t_{3}$ ) both remain constant. Belowground biomass is calculated as linear growth of the root between $t_{1}$ and $t_{3}$ until the maximum root length. With the end of the growth season (at time $t_{3}$ ) we assume a reduction in stem height to include decay and standing dead biomass of the plant. Root length and diameter remain constant.

The patches that survived the first year age into a different life-stage, from seedling to mature vegetation. For mature vegetation a different growth function is defined that allows them to grow larger and defines a larger bulk drag coefficient to account for leaves. The existence of multiple life-stages in one single grid cell is possible, where the maximum sum of all vegetation fractions in one cell equals one. A fraction represents the relative space in a grid cell covered. The generic salt marsh species is defined for all life stages by the values in Table 2.1. 
Table 2.1: Physical parameters of the generic salt marsh vegetation type based on a combination between Spartina anglica and Salicornia ssp.. $t_{1}, t_{2}$ and $t_{3}$ are onset of growth season, onset of maximum biomass in summer and onset of reduced biomass in winter. The seedling-stage changes into mature vegetation after year 1 with a maximum total age of the plant of 20 years.

\begin{tabular}{|c|c|c|c|c|}
\hline Generic species & unit & $t_{1}$ & $t_{2}$ & $t_{3}$ \\
\hline \multicolumn{5}{|c|}{ Seedling stage (1 year) } \\
\hline plant height $^{c, e}$ & {$[\mathrm{~m}]$} & 0.1 & 0.6 & 0.3 \\
\hline stem diameter $^{d}$ & {$[\mathrm{~m}]$} & 0.005 & 0.01 & 0.01 \\
\hline root length $b, e$ & {$[\mathrm{~m}]$} & 0.05 & 0.2 & 0.2 \\
\hline plant density $^{a}$ & [stems $/ \mathrm{m}^{2}$ ] & 500 & 500 & 500 \\
\hline bulk drag $C_{D}$ & {$[-]$} & 1.0 & 1.0 & 1.0 \\
\hline bed roughness $C_{b}$ & {$[\sqrt{m} / s]$} & 25 & 25 & 25 \\
\hline \multicolumn{5}{|c|}{ Mature vegetation (19 years) } \\
\hline plant height ${ }^{a, c, d}$ & [m] & 0.5 & 1.0 & 0.5 \\
\hline stem diameter ${ }^{a}$ & {$[\mathrm{~m}]$} & 0.01 & 0.01 & 0.01 \\
\hline root length ${ }^{c}$ & {$[\mathrm{~m}]$} & 1.0 & 1.0 & 1.0 \\
\hline plant density $^{a}$ & [stems $\left./ m^{2}\right]$ & 600 & 600 & 600 \\
\hline bulk drag $C_{D}$ & {$[-]$} & 1.1 & 1.1 & 1.1 \\
\hline bed roughness $C_{b}$ & {$[\sqrt{m} / s]$} & 25 & 25 & 25 \\
\hline
\end{tabular}

Note. ${ }^{a}$ Bouma et al. (2013), ${ }^{b}$ Cooper (1982), ${ }^{c}$ Davy et al. (2001)

${ }^{d}$ Nehring and Hesse (2008), ${ }^{e}$ Poppema et al. (2017)

\section{Mortality}

While the growth rules define the temporally changing physical plant properties in their initial locations (Figure 2.3), the mortality functions determine spatially-explicit vegetation removal based on Van Oorschot et al. (2016). We account for plant mortality linked to three types of pressures supplied by the HM-model: (i) drowning by hydroperiod, (ii) uprooting due to high tidal flow velocities, and (iii) burial and scour through erosion and sedimentation (Figure 2.3). For the hydrodynamic stressors ( $i$-ii) we use a linear dose-effect relation where the mortality rate increases with increasing pressure:

$$
\text { mortality fraction }=\left\{\begin{array}{l}
0, \text { if pressure }<\text { min. threshold } \\
m(x-b), \text { if min. threshold }<\text { pressure }<\text { max. threshold } \\
1, \text { if pressure max. threshold }
\end{array}\right.
$$

$m$ is the slope of the linear function, $x$ the stressor strength and $b$ the intercept. Linear mortality was chosen as it represents the plant's resilience to beginning pressures (Holling, 1973). The inundation thresholds are the same for both life stages, but velocity resilience increases with age (Cao et al., 2018). We chose the $95^{\text {th }}$ percentile of the maximum flow velocity of each tidal cycle as the representative velocity for plant mortality to avoid unrealistically high velocities at very small water depths due to numerical effects. Thresholds and derivation were taken from literature and estimated based on empirical studies (see Table 2.2).

In contrast to a gradual mortality rate for hydrodynamic pressures, the morphological pressures of burial and scour are assumed to be fatal to the entire plant fraction if the critical length $l_{\text {crit }}$ of the root or the shoot is exceeded by the erosion or sedimentation rate, respectively (eq. $2.7 \mathrm{a}$ and $2.7 \mathrm{~b}$ ). The critical root length is defined as $10 \%$ of the root, while the critical shoot length is $100 \%$ of the shoot. As root length is growing with time, the resilience 
Table 2.2: Mortality parameters of our generic salt marsh vegetation species. The values are based on a combination between Spartina anglica and Salicornia ssp.. The seedling-stage changes into mature vegetation after year 1 with a maximum total age of the plant of 20 years.

\begin{tabular}{lcc}
\hline Generic species & min. threshold & max. threshold \\
\hline Seedling stage (1 year) & & \\
inundation period $^{b}$ & 0.3 & 0.45 \\
uprooting & $0.25 \mathrm{~m} / \mathrm{s}$ & $0.4 \mathrm{~m} / \mathrm{s}$ \\
\hline Mature vegetation (19 years) & & \\
inundation period $^{b}$ & 0.3 & 0.45 \\
uprooting $^{a}$ & $0.4 \mathrm{~m} / \mathrm{s}$ & $0.56 \mathrm{~m} / \mathrm{s}$ \\
\hline Note. $^{a}$ Bouma et al. (2013) $^{b}$ Van Belzen et al. (2017) &
\end{tabular}

of the plant against scour increases with age, but resilience against burial changes with the seasonal variations of the shoot length. Mortality is calculated as:

$$
\text { plant fraction }=\left\{\begin{array}{l}
\text { plant fraction, if } l_{\text {crit }} \geq \text { erosion or sedimentation rate } \\
0, \text { if } l_{\text {crit }}<\text { erosion or sedimentation rate }
\end{array}\right.
$$

for which Table 2.2 summarizes the mortality parameterization.

\subsubsection{Scenarios}

We performed four steps (Table 2.3). For all scenarios intertidal area is defined as bed elevations above mean water.

First, we analyzed the performance of the eco-morphodynamic model nearly independently of the quality of long-term morphological modeling. To this end, the eco-morphodynamic model was run for four years on three different initial bathymetries derived from data in 2000, 2006, and 2011. These models are further referred to as vegetation- or V-scenarios compared to reference scenarios without vegetation, further referred to as R-scenarios. These specific years are compared to the available ecotope maps in 2004, 2010 and 2015, which span the development from sparse to dense salt marsh on the tidal bar. We kept our water level boundaries the same for all three runs and their reference runs. We carried out a cell to cell comparison between the eco-morphodynamic model results and the ecotope maps to quantify performance of the vegetation predictions using the MATLAB software package (version 2016a). We binarised the vegetation maps and classified correspondence into four categories: correctly predicted salt marsh, predicted but not observed (false positives), not predicted yet observed (false negatives) and correctly predicted absence of salt marsh. These categories were each summed and divided by total intertidal area.

Second, we ran the eco-morphodynamic model over the entire 15 year period and compared to a morphodynamic reference run without vegetation (further referred to as long term or L-scenario). We analyzed vegetation density and distribution along bed elevation and compared the results to predictions by a static model approach (S-scenarios), where vegetation presence is directly predicted from the inundation time thresholds used in the eco-morphodynamic model.

Third, to control for eco-engineering effects, we plot differences maps of the main parameters that control vegetation growth, hydroperiod, 95-percentiles of flow velocity and bed 
Table 2.3: Model scenarios based on initial bathymetries, years of simulation time, grid cell sizes, and the years of the ecotope maps that the results were compared to. We investigated the eco-morphodynamic model (V) for three bathymetries $(2000,2006,2011)$ and reference scenarios without vegetation $(R)$ for the same bathymetries. The V2000 scenario was also run for the entire period of 2000-2015 (V2000 L) to assess the long-term effects of morphological change and vegetation, complemented by a reference model run without vegetation (R2000L). Static vegetation maps (S) were computed to isolate eco-engineering effects. Model runs for two coarser grids on the bar (G1Bar, G2Bar) and spanning the entire estuary (G2Est) were conducted to investigate upscaling and grid size-effects.

\begin{tabular}{lcccc}
\hline Model scenario & Initial Year & Ecol. sim. time & Ecotope maps & Grid cell size \\
\hline V2000 & 2000 & 4 & 2004 & $\sim 16 \mathrm{~m} \times 27 \mathrm{~m}$ \\
V2006 & 2006 & 4 & 2010 & $\sim 16 \mathrm{~m} \times 27 \mathrm{~m}$ \\
V2011 & 2011 & 4 & 2015 & $\sim 16 \mathrm{~m} \times 27 \mathrm{~m}$ \\
V2000L & 2000 & 15 & 2015 & $\sim 16 \mathrm{~m} \times 27 \mathrm{~m}$ \\
\hline R2000 & 2000 & 4 & & $\sim 16 \mathrm{~m} \times 27 \mathrm{~m}$ \\
R2006 & 2006 & 4 & & $\sim 16 \mathrm{~m} \times 27 \mathrm{~m}$ \\
R2011 & 2011 & 4 & & $\sim 16 \mathrm{~m} \times 27 \mathrm{~m}$ \\
R2000L & 2000 & 15 & & $\sim 16 \mathrm{~m} \times 27 \mathrm{~m}$ \\
\hline S2000 & 2000 & 4 & & $\sim 16 \mathrm{~m} \times 27 \mathrm{~m}$ \\
S2006 & 2006 & 4 & & $\sim 16 \mathrm{~m} \times 27 \mathrm{~m}$ \\
S2011 & 2011 & 4 & & $\sim 16 \mathrm{~m} \times 27 \mathrm{~m}$ \\
\hline G1Bar & 2011 & 4 & 2015 & $\sim 45 \mathrm{~m} \times 45 \mathrm{~m}$ \\
G2Bar & 2011 & 4 & 2015 & $\sim 50 \mathrm{~m} \times 180 \mathrm{~m}$ \\
G2Est & 2011 & 4 & 2015 & $\sim 50 \mathrm{~m} \times 180 \mathrm{~m}$ \\
\hline
\end{tabular}

level, for the two bathymetries of 2000 and 2011. These maps are derived by subtracting the reference scenario $(R)$ from the scenario with vegetation $(V)$, hence they show vegetation effects. Here, the last tidal cycle is compared, which means bed level changes are a cumulative result throughout the entire simulation and represent a general trend, whereas the hydrodynamics are the end result and can directly be linked to the present vegetation cover.

Fourth, we applied the eco-morphodynamic model on the entire estuary scale on the coarser grid to gain insights into the large scale applicability and grid size-dependence. We specifically compare vegetation cover and location, the vegetation age distribution and quantify distributions of bed level and levels at which salt marsh formed as hypsometric curves.

\subsection{Results}

\subsubsection{Vegetation establishment in response to hydro-morphological conditions}

The ecotope maps between 2000 and 2015 show an increase in salt marsh cover, both in density and in area (Figure 2.4a). The predicted vegetation development in the V2000-, V2006and V2011-scenario is similar in extent and positioning (Figure 2.4b) in that both show establishment of dense vegetation across the central eastern side down to the southern tip of the bar, bordered by sparse vegetation around the edges (Figure $2.4 \mathrm{a} \& \mathrm{~b}$ ).

On the other hand, the V2000L-scenario over 15 years (Figure 2.4e), shows dense salt marsh cover at the center of the intertidal bar with a much smaller spatial extent than the 4 year simulations and the ecotope maps (Figure 2.4a-d). The only difference with the shortduration scenarios is the long-term development of morphology, indicating that the HM- 
model did not elevate the bar as much as evidenced by the observations. Two main differences between model and data emerge: all model simulations predict salt marsh to settle in the western part of the bar which is not found in the ecotope maps (Figures 2.4a-e and 2.5). Dense vegetation observed in the south-eastern part of the bar is not completely captured by the model.

To quantify correspondence and mismatch between predicted and observed salt marsh development we imaged the cell to cell comparison as relative binarised maps (Figure 2.5). The eco-morphodynamic model predicted around 60\% correctly in all three V-scenarios. The total vegetated area in the model was larger than in the ecotope maps, mainly due to the (false positive) prediction of salt marsh on the west of the bar. However, the vegetation cover was predicted increasingly well with the newer bathymetries in the V2006 and V2011 scenario. Most of the salt marsh in the middle and on the eastern side of the bar was correctly modeled, while the model underestimated vegetation cover at the marsh edge.

To understand how the observed vegetation patterns linked to bathymetry of the respective scenario we look at the relative bed elevation distribution of the V-scenarios compared to the $\mathrm{R}$-scenarios and the corresponding vegetation cover (Figure 2.6). The bed elevations of the bar increase over time from the V2000 to the V2011 scenario as shown after normalization to mean water level (Figure 2.6). The bed elevation increase causes a shift of the distribution mode from around $0.55 \mathrm{rMW}$ (relative to mean water level) for V2000 to $0.65 \mathrm{rMW}$ for V2006 and 0.7 rMW for V2011, respectively. Moreover, the maximum elevations of the bar are increasing over time while the area with lower elevations reduces around the lower limit of vegetation occurrence. On the other hand, the distribution of bed elevations of the long-term run V2000L of 15 years is rather similar to the V2000 scenario but much different from the bathymetry in the R2011 scenario that it targeted (Figure 2.6). This is the likely explanation for the observation that the vegetation did not extend as much in this model run as it did in the shorter duration vegetation scenarios with the higher observed bed levels.

The development of the average vegetation cover along relative bed elevation for the dynamic V-scenarios (Figure 2.7) shows that the increase over time is mainly due to the increase in higher elevated bar areas. For all bathymetries the area occupied by vegetation increased gradually with elevation, of which the maximum cover is found at the highest elevations. In comparison, the $\mathrm{S}$-scenarios predicted vegetation presence from upper- and lower thresholds in inundation period. The predictions result in general agreement with the $\mathrm{V}$-scenarios for the range of elevations that became vegetated, but the static scenarios could not predict the trend in vegetation cover with elevation. As the vegetation cover determines the resulting hydraulic resistance we look into their distributions below (Figure 2.7).

Modeled cover is strongly related to life stage. The majority of juvenile vegetation is located between 0.45-0.75 rMW and mature vegetation between 0.55 and $0.85 \mathrm{rMW}$ (Figure 2.8a). This distribution is directly linked with the density classes in Figure $2.4 \mathrm{~b}$, showing that the sparse cover is mostly made up of seedlings while the dense cover occurs mainly on highlying cells with an established mature salt marsh. Roughly two thirds of the surface of colonized relative elevations (between $0.55 \mathrm{rMW}-0.75 \mathrm{rMW}$ ) is covered both by sparse and dense, juvenile and adult vegetation. This indicates that cells with mature vegetation are sub- 


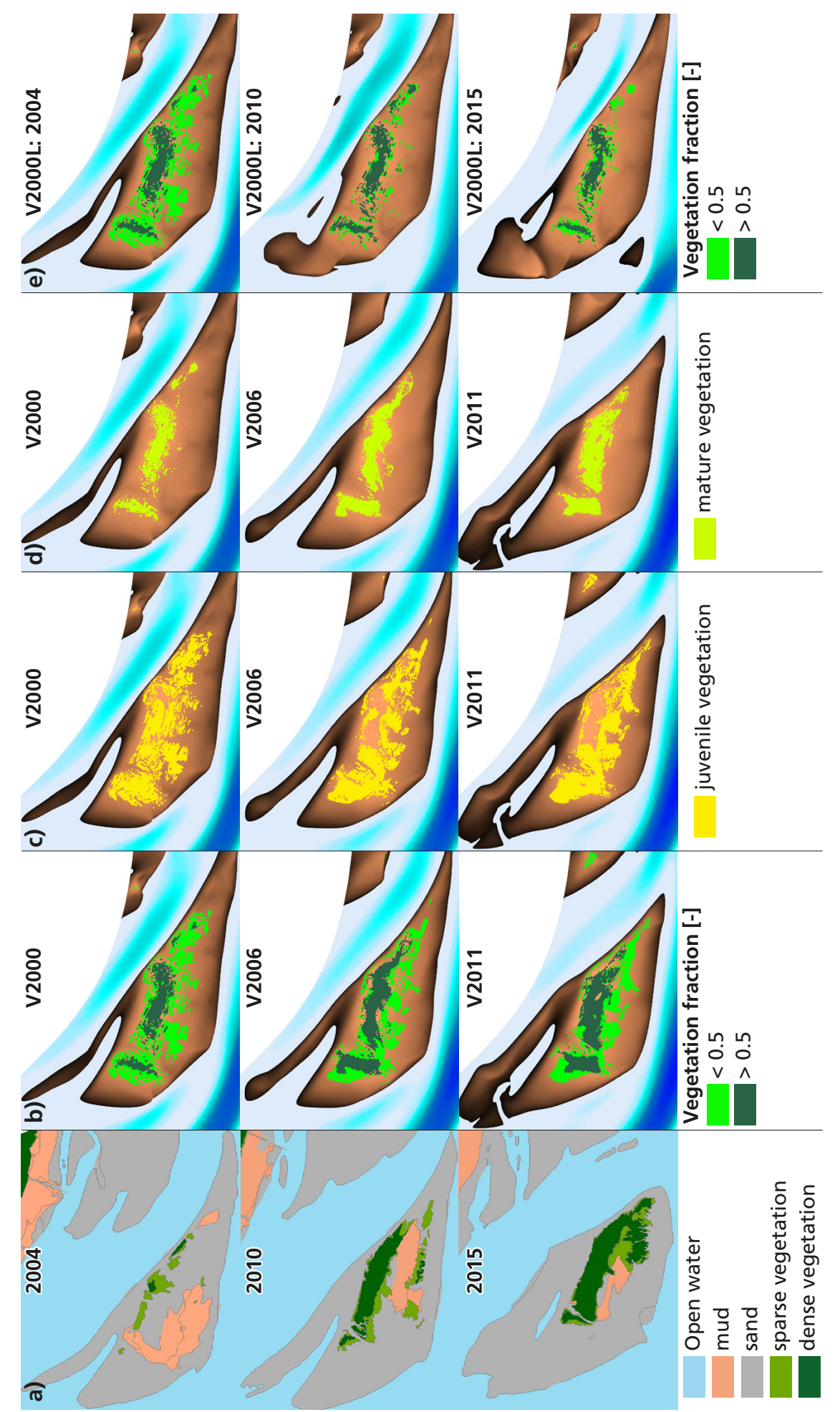

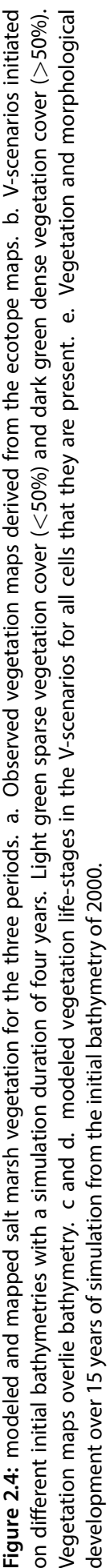




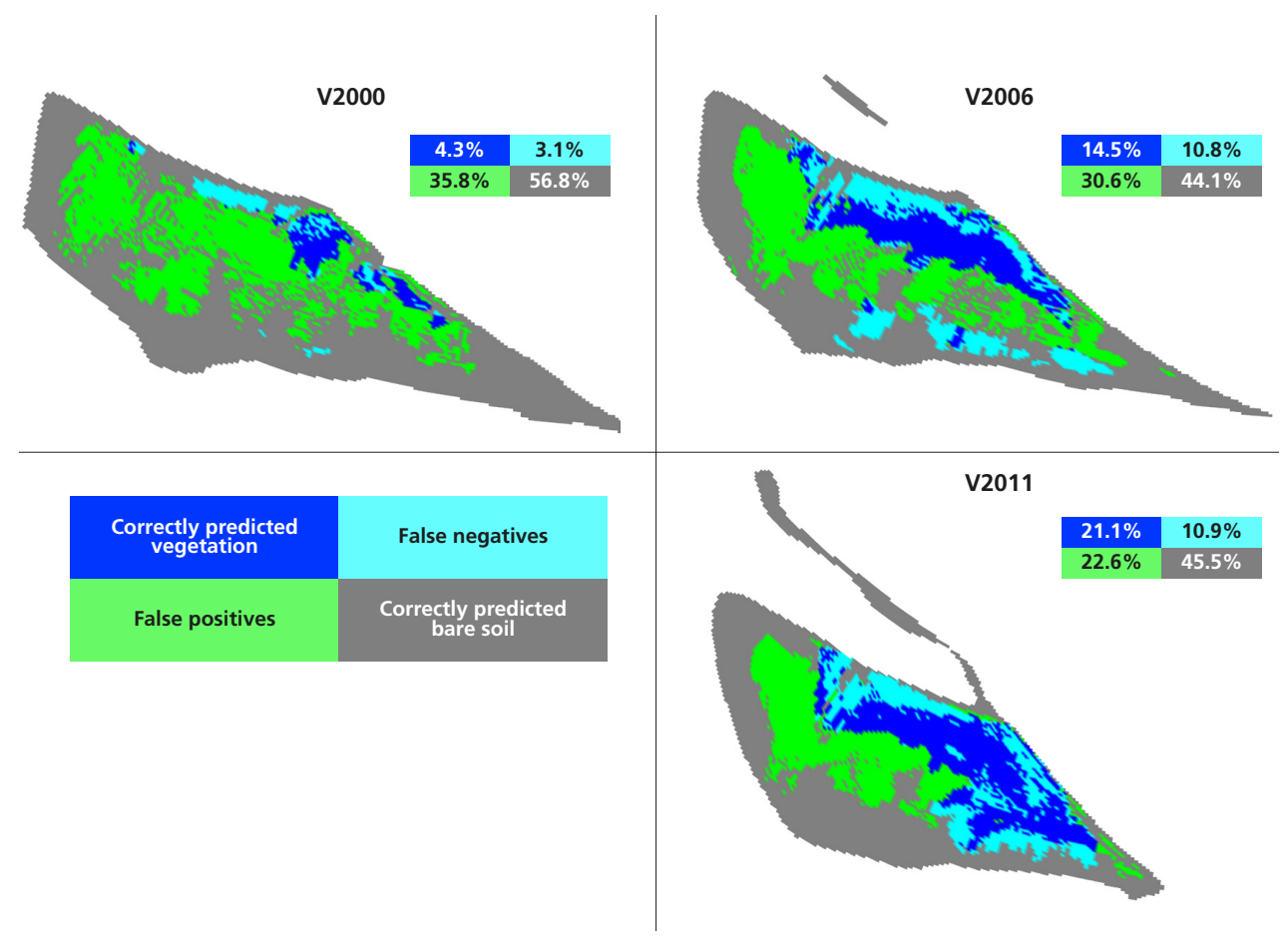

Figure 2.5: Spatial and summed correspondence of vegetation presence and absence between model scenarios and ecotope maps. Colors (legend bottom left) indicate correspondence in correctly predicted presence and absence of vegetation and the false negative and false positive predictions. The percentages of the correctly modeled cells give a measure for model performance.

ject to mortality and can partly be recolonized by seedlings. Only at the Eastern tip, where cells were only covered by mature plants, we found a hundred percent coverage and cells could not be recolonized (Figure 2.8b).

We found a relation between cover density and mortality causes through the ecologi$\mathrm{cal} /$ morphological year (Figure 2.9). For the V2000 scenario, at each grid cell the mortality causes were extracted and added up to calculate the relative contribution to the entire mortality at each time-step over one ecological year. If several mortality causes provoked dying of the plant patch they were classified as "combined pressures". The total cover increased at the beginning of the year, which can be attributed to colonization by new seedlings resulting in sparsely covered cells. Over the course of the simulation parts of the newly established vegetation died, due to high inundation rates while the mature dense vegetation remained constant. The strongest mortality occurred within the first time-steps after colonization as the seedlings were located at exposed locations where all pressures were exceedingly high. This process leads to a dynamic equilibrium of colonization and mortality of the vegetation with time. Interestingly, for higher bed elevations (V2006 and V2011) the ratio dense/sparse is increasing while in V2000 it is around one (indicated by the similar locations of the dashed and dotted line, Figure 2.9). This shows that the stability of the marsh is very low if the bed 


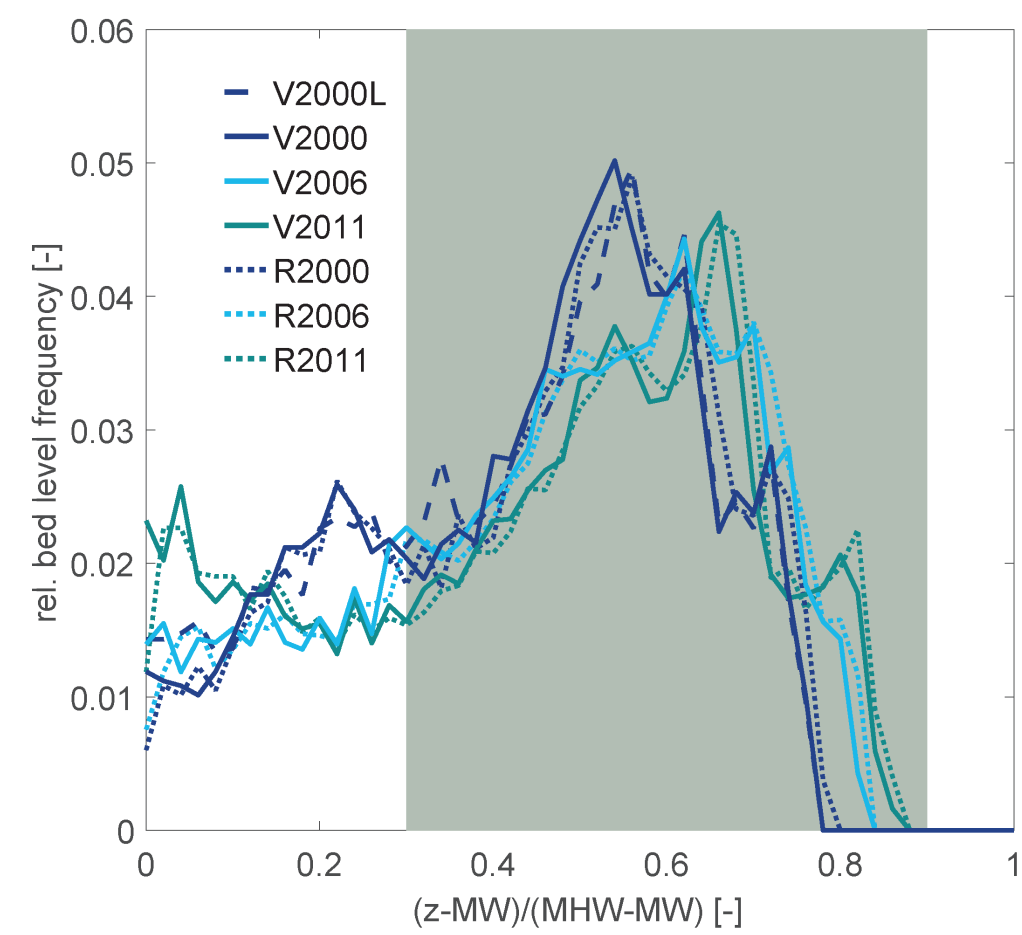

Figure 2.6: Relative bed elevation frequencies plotted against normalized bed elevation at the end of all V-and $\mathrm{R}$-scenarios showing an increase in bed elevation with time. Minor morphological change due to vegetation was found. modeled vegetation grows within the gray zone.

elevation is not sufficiently high. In comparison, the static vegetation scenario does not account for mortality; hence the cover is constant with time.

\subsubsection{Eco-engineering effects of the dynamic vegetation}

While hydro-morphodynamic conditions influence vegetation cover and density, the vegetation in turn influences these conditions. These eco-engineering effects in hydro-morphodynamics were calculated as differences with the reference runs (R-scenarios) without vegetation (Figure 2.10).

Three contrasting effects emerged. As expected, the flow velocity magnitude on the bar is reduced through vegetation cover. Second, the morphological difference is fairly limited, with the largest effect occurring in the V2000 scenario when the salt marsh had the smallest extent and nearly absent accretion on the marsh. The third and unexpected result is that the inundation duration increases with salt marsh extent, meaning that the presence of vegetation increases the inundation stress for the vegetation. As the bathymetry of the bar increased in elevation and vegetation cover, all effects became more pronounced (Figure 2.10).

Flow velocity in and around the vegetated area is considerably lower than without vegetation, up to $0.4 \mathrm{~m} / \mathrm{s}$. On the other hand, flow velocity is higher in deeper channels developed in the presence of vegetation, especially in V2011 where the cover was largest. 


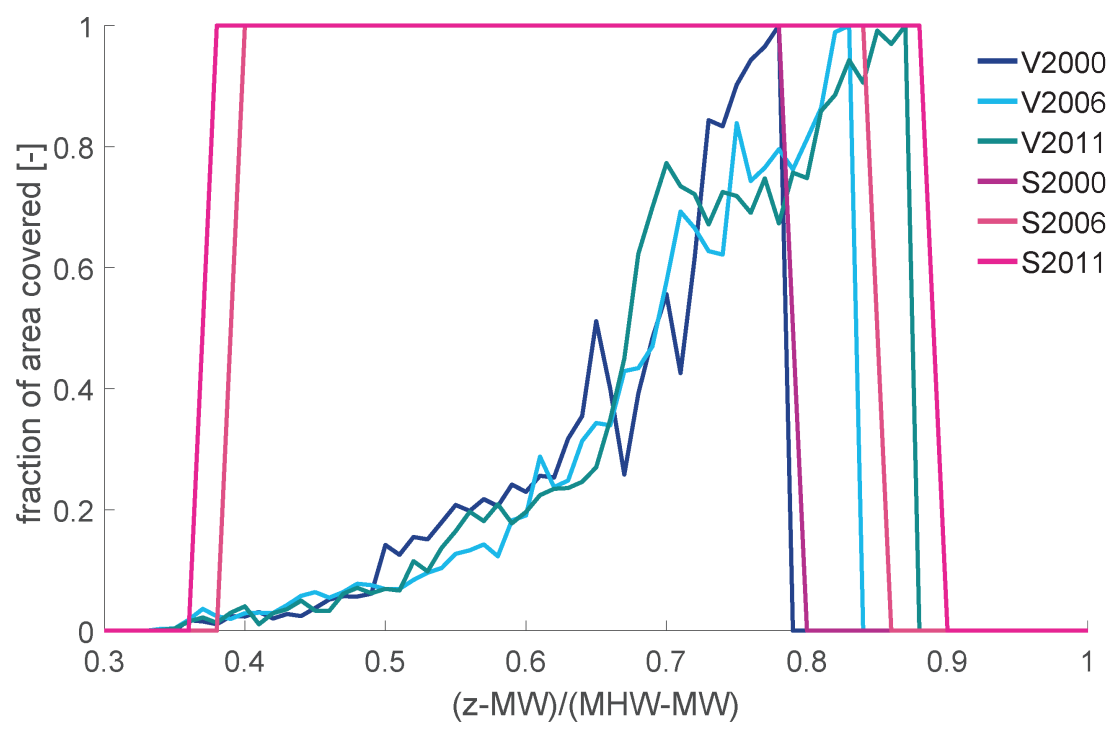

Figure 2.7: Distribution of the fractional area cover plotted against normalized bed elevation at the end of the 4 year simulations. Vegetated grid cells only in the V2000, V2006, and V2011 scenarios show the development of a larger vegetation cover at higher bed elevations while the static S2000, S2006, and S2011 calculations result in a constant coverage along the bed elevation gradient.
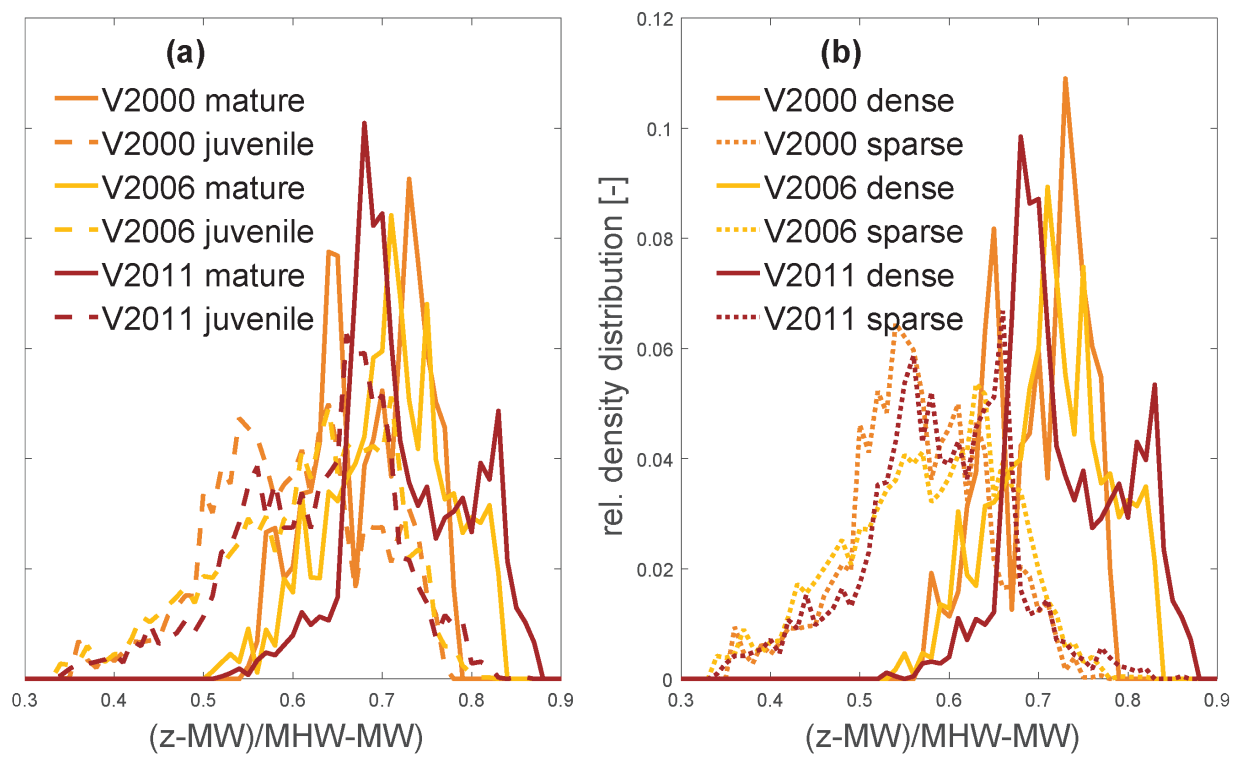

Figure 2.8: Comparison of the vegetation life-stages with cover density along normalized relative bed elevation at the end of the 4-year simulation. a) relative coverage per relative bed elevation class for the intertidal area of the two life-stages and all three bathymetries. b) relative coverage by the two density classes. We observe a correlation between an increase in life-stage and density along the elevation gradient. 


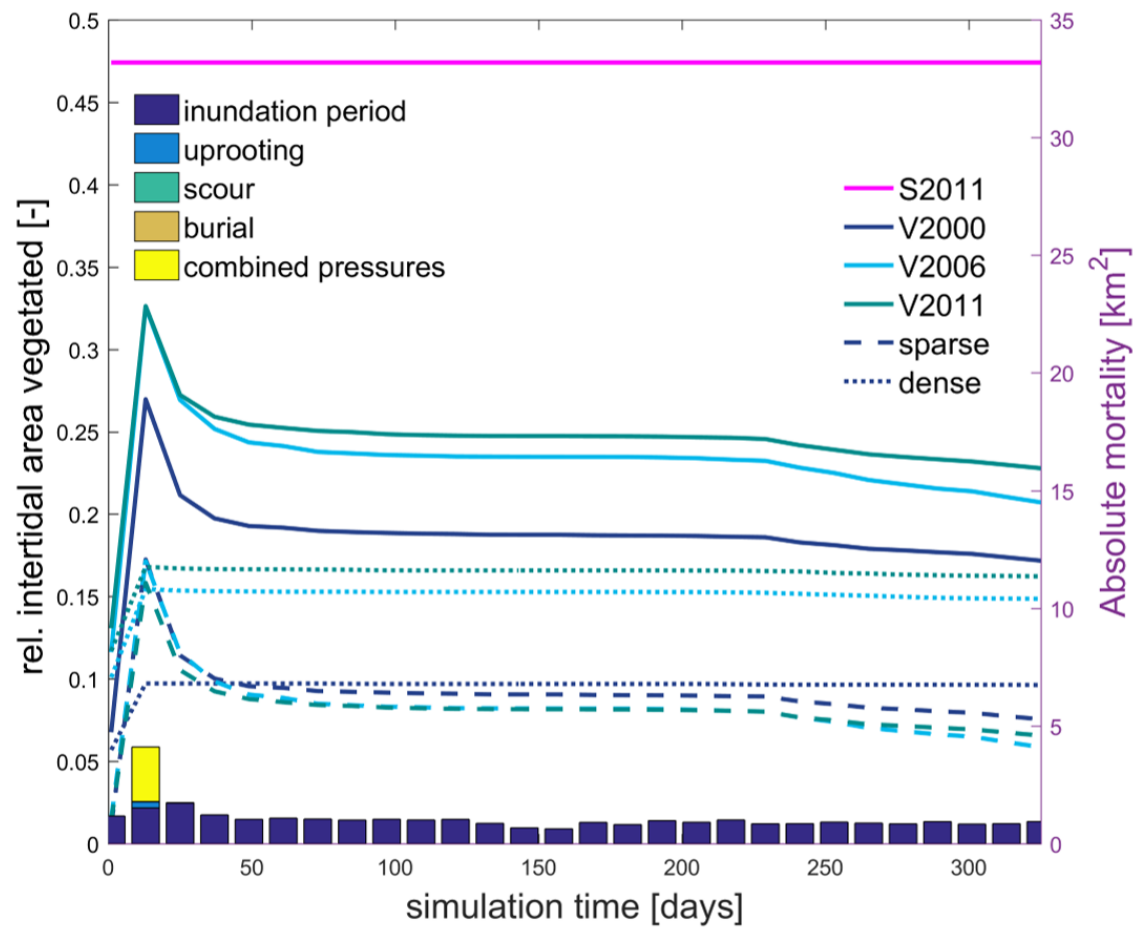

Figure 2.9: Changes of the total fractional area cover and the two density classes within one representative ecological year of the V-scenarios (lines) and related mortality causes (bars). Vegetation colonization leads to an increase of cover by the seedlings at the colonization time-step followed by immediate mortality by combined mortality causes, inundation and uprooting of the sparse patches. Throughout the year the relative vegetation cover reduces gradually with dying of the sparse patches by only inundation stress whereas the dense vegetation remains constant. The static scenario shows a constant cover for 2011.

The indirect feedbacks between vegetation and morphology are limited (Figure 2.10), except at the northern tip of the bar close to the flood channel where the flow is deviated during flood. This causes high dynamics in the sedimentation and erosion pattern. The flow is accelerated along the marsh edge which leads to erosion next to the marsh and immediate sedimentation next to eroded cells. This effect is especially pronounced on the lowest bathymetry (V2000) which is more regularly flooded and a change in hydrodynamics by vegetation can have a potentially larger effect. Bed level change is fairly limited considering the large vegetation cover on the bar.

The larger roughness due to vegetation led to a longer residence time of the water on the bar and thus increasing the hydroperiod. This effect was increasingly pronounced with higher bar elevations due to smaller relative water depth and increased vegetation cover, reducing the drainage after high water. This is the opposite of the idea that the plant is changing its environment to its favor. The increase in inundation was also observed away from the marsh indicating a larger regional effect of the marsh. 


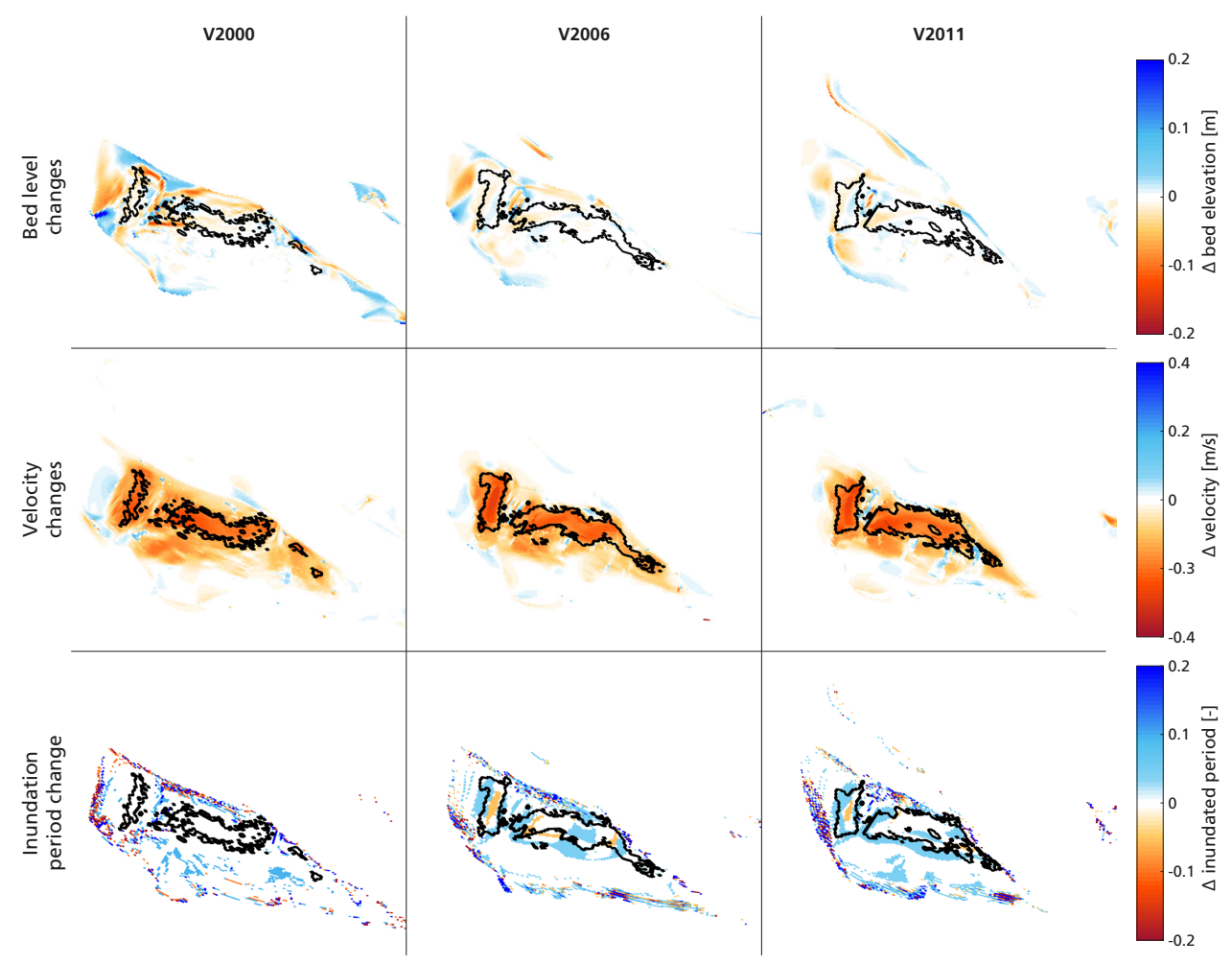

Figure 2.10: Effects of vegetation on hydromorphology calculated by differencing with the R-scenarios without vegetation at the last time-step for all three bathymetries (columns). Top row: difference in bed level elevations. Middle row: difference in $95^{\text {th }}$ percentile maximum flow velocity. Bottom row: difference in inundation period, assuming a flooding-drying threshold of $5 \mathrm{~cm}$. The dense salt marsh ( $>50 \%$ cover) is indicated by black contour lines.

\subsubsection{Numerical effects and test of upscaling}

The grid size resolution is an important aspect for the simulation of vegetation cover. An analysis of two coarser grids (runs G1Bar and G2Bar) shows that the vegetation cover reduces with grid size, hence, there is a relation between numerical effects and upscaling to larger, coarser grid cells. The decrease in vegetation cover is explained by the increase in inundation period for the coarser grid cells (Figure 2.11). The velocities were however decently distributed over the different grid sizes. To compensate for the increased inundation period we raised the flooding-drying threshold from $2 \mathrm{~cm}$ to $10 \mathrm{~cm}$ for the vegetation calculations (Figure 2.11). This led to a realistic vegetation cover on the coarsest grid for the bar (Figure 2.11, coarse, FD-threshold:0.1m).

To test the possibility for upscaling the vegetation model to a coarse grid we applied a vegetative flooding-drying threshold of $10 \mathrm{~cm}$ (G2Est-scenario). The results in comparison with the ecotope map are adequate (Figure 2.12). The salt marshes along the estuary margins were well reproduced, as were the large bars "Hooge Platen" and "Walsoorden". The salt marsh of "The drowned land of Saeftinghe" was underrepresented with a lower cover than 


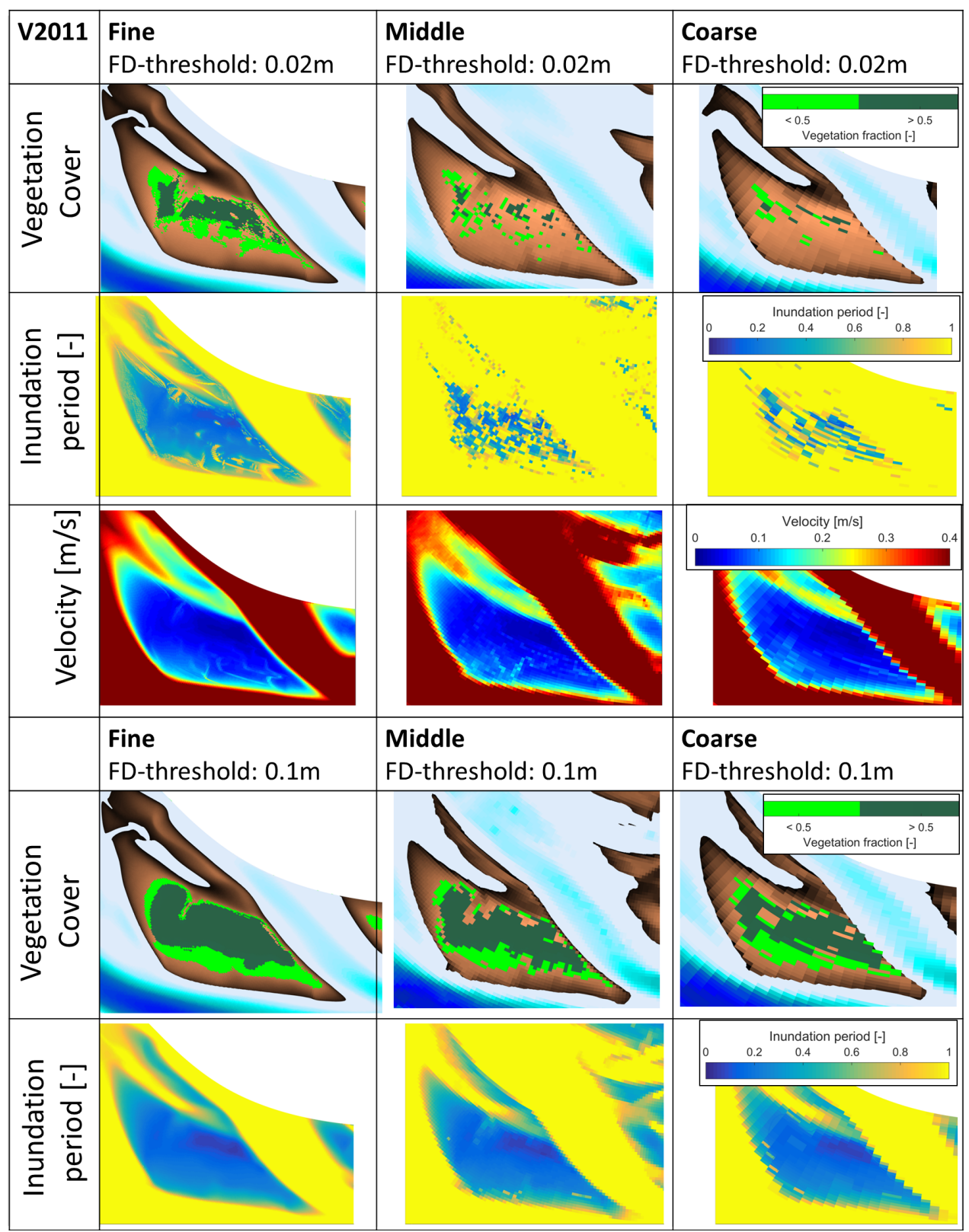

Figure 2.11: Grid size dependency of inundation period, peak velocity (95\%) and vegetation settlement for three different grid sizes and bathymetry of V2011 (rows). The increase in grid size increases the inundation period, affecting vegetation cover (columns). Velocity is not significantly affected by the change in grid size. We compare the hydrodynamics and vegetation cover for two different flooding- drying threshold (FD-threshold) for the vegetation calculations along the different grid sizes, showing that the increased grid size can be compensated by an increased FD-threshold (lower two rows). 


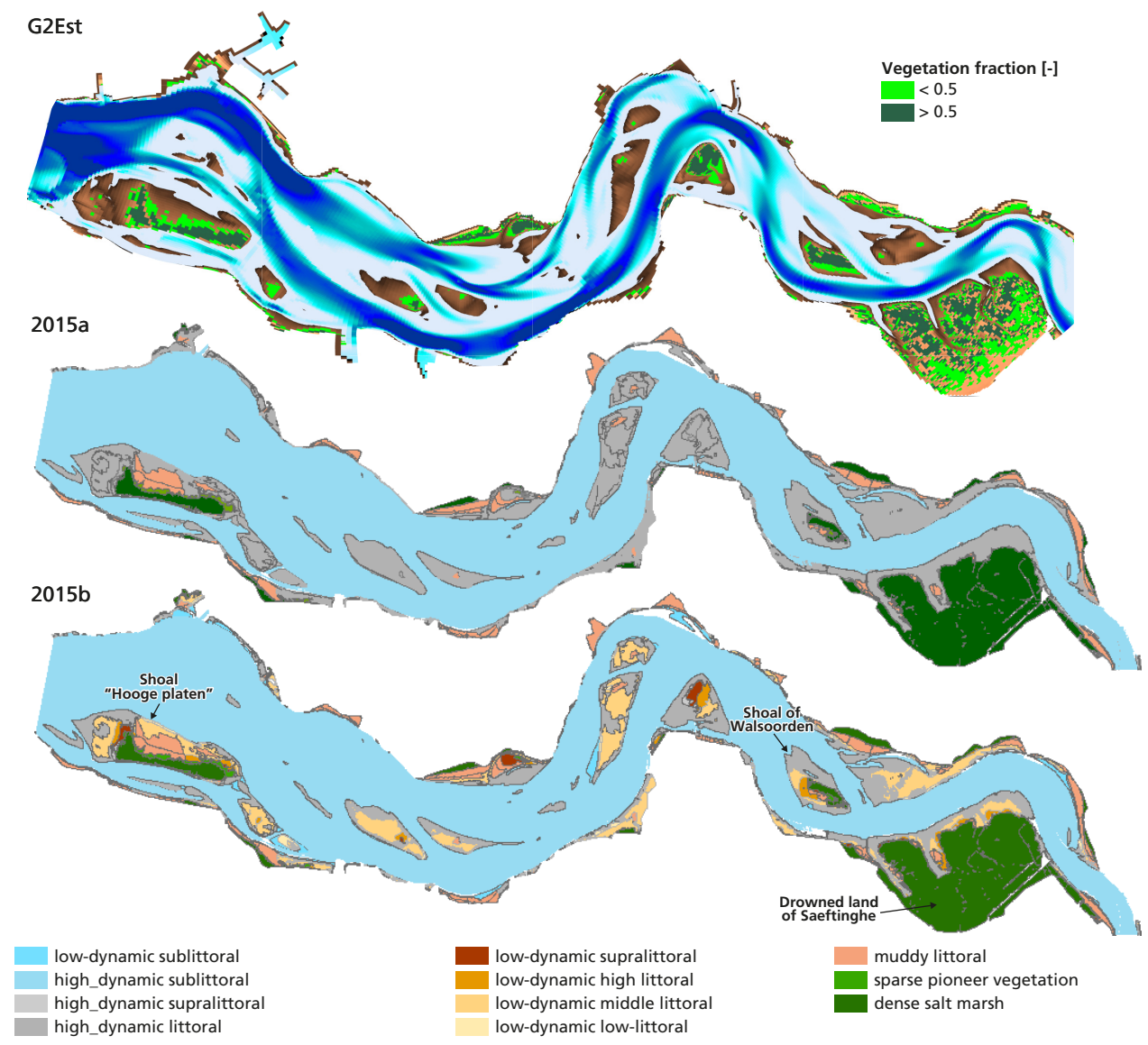

Figure 2.12: G2Est - scenario of the entire Western Scheldt modeled for the large grid cell sizes compared to the original (b) and simplified (a) ecotope map of 2015, respectively. Compared to ecotope map 2015a the vegetation is correctly predicted along the estuary margins and on the bar "Hooge Platen" and Walsoorden while some additional smaller bars are falsely covered. The Drowned land of Saeftinghe, a very old and highelevation salt marsh, has smaller vegetation predictions than mapped.

in the ecotope maps while the eco-morphodynamic model falsely predicted plant cover on some smaller bars. The areas with false cover predictions are classified as low-dynamic high and supralittoral or muddy littoral in the original ecotope map.

\subsection{Discussion}

The vegetation cover acquired with our novel eco-morphodynamic model compare well with the ecotope maps both for salt marsh location and density. Literature-based values of vegetation properties are sufficient to predict the locations and cover of the generic salt marsh with an accuracy of $60 \%$ after a simulation period of four morphological years. Hence, a calibration of the vegetation parameters in the dynamic vegetation model for different bathymetries 
is not necessary, which makes the model unique and opens up possibilities to evolve a generic code for a variety of systems in the future.

We found salt marsh density and age (expressed as life-stages) to positively correlate (Figure 2.8), which agrees with previous observations in salt marsh zonation (Adam, 1993). In contrast with literature, our model results show an increase of the hydroperiod next to the established salt marsh, suggesting an unexpected negative eco-engineering effect (Figure 2.10). More specifically through the salt marsh induced increase in hydroperiod salt marsh expansion becomes limited adding a new dimension to scale-dependent vegetation-landform interactions. Possibly this opens up niches for other species not yet included. Finally we show that the grid size affects the calculation of the drying and flooding hydrodynamics and thus the prediction of vegetation patterns.

\subsubsection{Density gradient - plant age and fast-slow colonizers}

Our model results show a vegetation density gradient along the bed elevation (Figure 2.7). This is a typical pattern observed in pioneer marshes, where the high marsh is characterized by dense and mature vegetation while limited seedling survival and lateral expansion cause sparse cover at low elevations (Gray and Bunce, 1972). The patterns in our model emerged from the dynamic, literature-based, rules that are prescribed for the two life-stages, where seedlings are smaller and more susceptible to velocities. The young plants need a disturbance-free period to grow sufficient roots that can withstand the flow (Wiehe, 1935; Balke et al., 2012). As soon as sufficient time has passed, the vegetation grows and develops a strong root system that prevents erosion, which is parameterized by the mature life-stage (Cao et al., 2018). Our model results indicate that the main eco-engineering effect for plant survival is that the increase in plant height and stem width reduces the flow strength, and at the same time increases plant resilience. This reduced flow also causes low erosion rates on the bar, which renders possible stabilizing effects of plant roots unimportant (Figure 2.10). Consequently, the altered environmental conditions by these sparse seedlings facilitate the survival of the next generation of seedlings.

At the same time, since the eco-morphodynamic model allows different life-stages within the same grid cell it also incorporated shielding of younger plants by the older and larger plants (Bouma et al., 2007). On the other hand, the life stage-specific stress tolerance of the seedlings also causes increased mortality at these lower elevations. which results in the simulated density gradient as observed in field studies (Christiansen et al., 2000; Van der Wal et al., 2008). This effect can also be observed at small-scale salt marsh-mudflat features, such as unvegetated tidal channels caused by flow concentration between vegetation patches (Temmerman et al., 2007; Van Wesenbeeck et al., 2008). The degree of flow concentration and channel emergence is a function of the flow field, vegetation density and water depth. Our model reproduces flow concentration through the interplay between eco-engineering effects and life-stage dependent growth and mortality (Figure 2.10).

Salt marshes are characterized by various primary colonizers (Schwarz et al., 2018), which we only indirectly modeled. Firstly, species establish that have low densities and short lifespans, which reduce the flow and enhance bed accretion. These fast-colonizers facilitate establishment of successional species by their eco-engineering activity. Slow-colonizers usually 
have higher densities and are perennial, meaning that they start regrowing in the subsequent year. Throughout their life-span both strategists can co-occur at similar elevations on the intertidal flat (Suchrow and Jensen, 2010). We indirectly modeled these traits with our generic salt marsh species as a mix of fast and slow colonizers through specification of the life-stages. In doing so, we first allow an establishment of the rather small fast-colonizers on the bare sandflat with sparse densities. In locations with sufficient shielding through elevation or eco-engineering the plants survive their first year and become more resilient plants that can grow higher and in larger densities. At the same time, they become more resistant to velocity stress, which is a main trait of slow-colonizing plants. This means that the modeled generic species represents the properties of different pioneer species as Salicornia ssp. and Spartina anglica through the life-stages.

\subsubsection{Feedback between eco-engineering effects and salt marsh vegetation}

Hydroperiod is the main control of vegetation growth and sedimentation, which depends equally on the water levels and the bed elevations of the system (Reed, 1990; Adam, 1993; Allen, 2000; Mudd et al., 2004; Kirwan et al., 2010). However, water levels and bed elevations are co-dependent, vegetation reduces flow velocity in dense marshes, which influences hydroperiod and leads to higher sedimentation rates at the marsh edge rather than in the inner marsh (Townend et al., 2011). Also Neumeier and Ciavola (2004) observed that canopies act more as erosion protection than enhancing accretion under normal conditions. This agrees with our results, where bed level changes mainly occur adjacent to the marsh, while the short hydroperiod and the low sediment mobility of the single grain size within the marsh caused insignificant sediment transport.

In contrast with previous studies, a new negative eco-engineering effect emerged. While locally the salt marsh reduced the velocity magnitudes, making conditions more favourable for further settling, the inundation period was increased by the presence of extensive vegetation cover, which acts as a constraint on its spatial extent (Figure 2.10). Especially at the lower elevations away from the dense marsh edge this effect causes mortality of young vegetation. Consequently, this new eco-engineering effect directly limits the marsh's growth and hampers salt marsh expansion in sandy dynamic systems on marsh-scale. It was already stated by Nepf (1999) that effects on flow increase with distance from the marsh, who were further supported by the theory of large- and small-scale dependent feedbacks between vegetation and mudflat, (e.g. Van Wesenbeeck et al., 2008; Schwarz et al., 2015a; Schwarz et al., 2018). Similarly, we found eco-engineering effects on flow rates at the marsh-scale. Interestingly, even though the cover increased gradually with elevation in the eco-morphodynamic model, the positive engineering effect on the velocity magnitudes is relatively strong (Figure 2.10: 2004, 2010, 2015). Contrarily, the "marsh-scale negative eco-engineering effect" only seems to become visible after a certain salt marsh size developed (Figure 2.10: 2010, 2015).

To quantify the importance of the eco-engineering effects on vegetation patterns we compared the results of our eco-morphodynamic model to a static model for the lowest bed elevations in 2000 and highest bathymetry of 2011 (Figure 2.13). The static model prescribes vegetation growth based on thresholds for inundation period. We determined the mean inundation period over the four years of a run without vegetation cover and prescribed veg- 


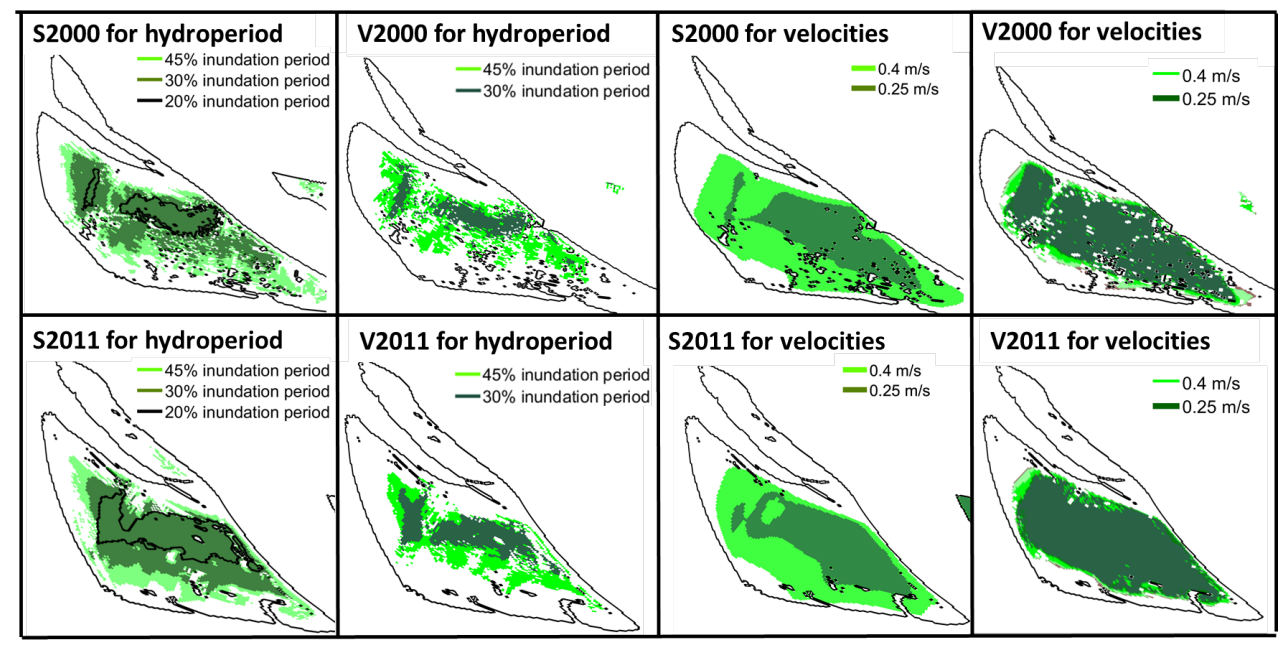

Figure 2.13: Comparison of the static $(S)$ and dynamic $(V)$ modeling results to quantify eco-engineering effects. The difference in cover between the $S$ - and V-scenarios for two years reveal the enhanced mortality through longer inundation periods caused by eco-engineering effects (left two columns). The right two columns display the vegetation difference between the S- and V-scenario when we only consider mortality through uprooting, showing a facilitation of plant survival by positive eco-engineering effects on velocity.

etation based on the benchmarks found in literature. We see that for the same threshold of 0.3 inundation period the static vegetation cover is larger for both S-scenarios than the corresponding eco-morphodynamic model results, which can be directly attributed to the marsh-scale negative eco-engineering effect of the inundation period. To quantify their difference we add a lower threshold of 0.2 to the static maps which produces a similar pattern as the eco-morphodynamic model with 0.3 . The marsh-scale negative eco-engineering effect already shown in Figure 2.10 led to higher mortalities that reduced the vegetation cover in the eco-morphodynamic model compared with the static model, limiting the predictive capabilities of static model approaches. At the same time, positive engineering effect for velocities were found where dense vegetation can expand further on the bar while it is shielded from present plants (corresponding with Figure 2.10). This supports our theory that velocity reduction strongly facilitates the survival of seedlings and allows for marsh expansion, even without large sediment supply.

The results stress the importance of a dynamic vegetation model, since vegetation alters the pressures causing its survival. While some factors are improved by the plants, the most important factor, inundation period, is not positively eco-engineered in the absence of fine sediment trapping and significant organic material production. As a result, vegetation predictions require consideration of dynamic feedbacks between newly established vegetation and environmental factors, including a detailed representation of their physical appearance that controls the magnitude of their eco-engineering effect. Static predictions do not capture the variations in eco-engineering effects. While being unsuitable for predictions of new salt marshes, static predictions can give insights into the impact of vegetation on morphology in hindcasting scenarios. This finding is especially important for modeling studies predict- 
ing future colonization of salt marsh, quantification of coastal protection, and management strategies on the system scale and along the fluvial-tidal transition.

\subsubsection{Effects of limitations in the morphological model}

A comparison with a continuous run simulating morphologic development over 15 years showed a bigger disparity between the model and the ecotope maps (Figure 2.4). We believe that this difference is not caused by shortcomings in the dynamic vegetation model, but is related to lower bed accretion rates than observed in reality, possibly caused by simplifications of the HM-model, i.e. the choice of the sediment fraction or disregarding dredging activities. Even though the Western Scheldt is predominantly sandy, natural variations in sediment fractions as well as redistribution of sediments by dredging and dumping possibly lead to larger sedimentation rates than predicted by the model.

The HM-model includes one sand fraction of $200 \mu \mathrm{m}$ that is representative for the main channels but neglects finer fraction typically observed in more sheltered areas (Gray and Bunce, 1972; Braat et al., 2017), which potentially are important for their vertical build up. Vegetation uses organic accumulation and fine sediment trapping as two mechanisms to increase bed level elevation (Turner et al., 2002; Le Hir et al., 2007; D’Alpaos, 2011; Braat et al., 2017). Due to the choice of the sediment and the vegetation growth strategy, both processes are not yet accounted for in the eco-morphodynamic model. This can explain the low bed level differences between the R- and V-scenarios (Figure 2.7) and the reduced bed accretion rates compared with reality.

The other factor controlling marsh expansion and bed accretion is sediment supply (e.g. Friedrichs and Perry, 2001; Mariotti and Fagherazzi, 2010). After a pilot dumping of 500,000 $\mathrm{m}^{3}$ in 2004, dumping adjacent to the bar has been carried out extensively from 2010 on with yearly between $500,000 \mathrm{~m}^{3}$ to $1,300,000 \mathrm{~m}^{3}$ of dredged material (Leys et al., 2006; Plancke et al., 2017). The artificial sediment supply by the redistribution of the dumped sediment can have had a significant part in the observed increase in bed elevation between 2000 and 2015 in the V2000L-scenario (Cleveringa, 2014). This at least partly explains the mismatch between observed and modeled bed level changes over a simulation period of more than one decade.

At the same time, vegetation covers a larger area on the bar compared to the ecotope maps. This could be linked to the roughness distribution on the bar as the HM-model only considers sand. Mud that can be found on the bar was not included in the calibration due to large computational expenses and prior calibration efforts, but would result in lower roughness values in reality. Sensitivity runs with a lower bottom roughness in both domains resulted in higher velocities on the western side of the bar, which removed newly established vegetation. Consequently, roughness effects induced by sediment type are a possible contributor to reduce vegetation abundance. At the same time, at the north-eastern bar margins vegetation cover is lower in the model (Figure 2.5). The model is not able to predict the bed forms that are characterizing that area, causing higher flow and mortality in the highly dynamic areas near the flood channel.

Sediment type also controls vegetation density. Van Hulzen et al. (2007) showed that sediment accumulation and vegetation density were enhanced on mudflats compared to sand- 
flats. Parameterization of sediment dependence of vegetation in the dynamic vegetation model can give new insights into their establishment mechanism and offer new possibilities for coastal sediment management. For example, modeling with sand and mud fractions in combination with the dynamic vegetation model could elucidate under what conditions mud flats appear that facilitate plant settling, or plants settle that cause mud to accrete.

The entire estuary model with vegetation largely reproduced the cover in the ecotope maps (Figure 2.12). However, the model predicts a smaller vegetation cover at the large Drowned land of Saeftinghe marsh than in the ecotope maps, which is due to a combination of two factors. First, in the original flow model the Saeftinghe area was calibrated with a high constant hydraulic roughness due to the pronounced vegetation cover (Vroom et al., 2015). This led to high hydroperiods as the water was unable to flow off the marsh after flooding, causing high and unrealistic salt marsh mortality in our eco-morphodynamic model. Second, the natural bed elevations of the Saeftinghe marsh are high compared to the bars. This is due to the high age of the marsh which allowed vegetation-induced sedimentation to such high bed elevations that the marsh cannot be flooded every tidal cycle (Stark et al., 2017).

At the same time, some of the bars were predicted to have salt marsh establishment while the observations show bare soil. This can be linked to growth-hampering processes lacking in the eco-morphodynamic model, such as shipping waves, strong secondary currents and highly three-dimensional flows in the sharpest bend in the middle of the model grid. Interestingly, most of the falsely predicted marsh is linked to the low-energetic classes or supralittoral (Figure 2.12). These areas have a high bed elevation and are already low in dynamics, hence, potentially suitable for vegetation establishment.

Stochastic (e.g. Temmerman et al., 2007; Schwarz et al., 2015a; Schwarz et al., 2018) or deterministic model approaches (e.g. Kirwan and Murray, 2007; D’Alpaos et al., 2012) both allow for a good representation of natural salt marsh patterns. Both approach are able to simulate salt marsh development, while the former is often used to describe emergent properties such as tidal channel formation, the advantage of the latter is to be able to compare governing parameters through deterministic scenarios. Patch formation of salt marsh vegetation is not represented in the current model as we focus on large-scale morphology and salt marsh growth requiring larger grid sizes. In spite of the model neglecting small-scale vegetation and morphological features, we show that realistic vegetation patterns emerge that give new insights into the interactive effects between salt marsh growth and morphology.

Further investigations are needed to link multiple species effects on sediment. We suspect that sediment supply is the limiting factor for bed level accretion in the model, which creates the need of adding fine sediment supply and dumping to the model for future model runs. The effects of other ecological features of vegetation need to be tested to understand the parameters needed to accurately model vegetation effects in fluvial and coastal environments and enhance morphological modeling. 


\subsection{Conclusion}

Without calibration, our eco-morphodynamic model correctly predicted the decadal salt marsh settling and expansion trend on the bar of Walsoorden based on vegetation parameters reported in literature.

The eco-morphodynamic model produced diverse vegetation patterns through density gradients and eco-engineering effects. Density of the marsh varies spatio-temporally due to the presence of multiple life-stages that have different physical plant properties and resilience. These life-stages also allow distinctions between fast- and slow-colonizers which opens up possibilities to test a variety of ecological concepts and eco-geomorphological interactions. While hydromorphic conditions determined the vegetation settling and initial mortality patterns, two eco-engineering effects of vegetation emerged. (1) The reduced flow velocities due to hydraulic resistance allow for an expansion of the salt marsh area. (2) Extensive vegetation cover increased the inundation period causing higher mortalities, which resulted in a negative eco-engineering effect. As a result, in sand-dominated systems salt marshes emerge from an equilibrium between positive and negative eco-engineering effects. A static vegetation presence model based on hydrodynamic thresholds mispredicted the observed vegetation patterns because it lacked the feedbacks between vegetation and hydro-morphodynamics. Consequently, spatial pattern and stability of the marsh depend on a combination of shielding by vegetation as well as plant resilience, which depends on the age of the marsh.

When predicting vegetation cover along the entire Western Scheldt estuary, grid size effects need to be accounted for to accurately represent the hydro-morphodynamics. The underrepresentation of the drying and flooding process on the coarser grids can be compensated by a different water depth threshold for inundation.

Our results support the hypothesis that salt marshes in estuaries in fact control not only local processes but also the marsh-scale. This suggests that vegetation affects the large-scale pattern of channels, bars, and overall planform of estuaries.

\section{Acknowledgements}

We thank the reviewers for careful reading and contribution to the quality of this work.. This research was funded by the ERC Consolidator project 647570 and Utrecht University. The ecotope maps were created by the Dutch Water Authorities (Rijkswaterstaat) and can be found on their website (https://www.rijkswaterstaat.nl). The Nederlands-Vlaams-Model was created and calibrated by Deltares. Delft3D is an open source code available at https://oss.deltares.nl. We want to thank Lisanne Braat for provision of her model for the same area to support our analysis. The authors contributed in the following proportions to conception and design, modeling, analysis and conclusions, and manuscript preparation: $\operatorname{MZMB}(50,80,70,65 \%), \operatorname{CS}(20,0,15,10 \%), \operatorname{WMVD}(10,10,0,5 \%), \operatorname{MVO}(10,0,0,5 \%)$, $\operatorname{HD}(0,10,0,0 \%)$, and $\operatorname{MGK}(10,0,15,15 \%)$ 


\section{Chapter 3}

\section{What came first, mud or biostabilizers? Elucidating interacting effects in a coupled model of mud, saltmarsh, microphytobenthos, and estuarine morphology}

Mud accretion and establishment of biostabilizers, such as microphytobenthos and saltmarsh vegetation, govern the development of estuarine morphology. Mud facilitates saltmarsh survival and microphytobenthos growth, which in turn promotes sedimentation and reduces mud erosion. Consequently, an increasing extent and thickness of mud cover might lead to a stabilization of large-scale estuarine morphology. To disentangle the interactions between saltmarsh establishment, microphytobenthos colonization and mud layer formation, we use our novel eco-morphodynamic model applied to the Western Scheldt estuary. Our model shows that presence of dynamic saltmarsh vegetation and microphytobenthos enhances predictions of mud location in the computations compared to field data. Saltmarsh establishment is partly determined by the antecedent mud content in the bed, resulting in varying emerging vegetation coverage between model experiments of a generic saltmarsh and a saltmarsh species that requires prior mud for establishment. In contrast to microphytobenthos enhancing seasonal mud accretion during their growth period, saltmarshes promote largest accretion when lower biomass and high water levels are present. Interestingly, thick long-term mud is enhanced despite the biostabilizers seasonal growth. The combination of saltmarsh and microphytobenthos leads to expanding saltmarsh cover and mud area. Generally, mud layer thickness is governed by the ratio of hydroperiod and maximum flow velocity that is mediated by the biostabilizers. On estuary scale, the presence of intertidal vegetation leads to increased mud volumes in the intertidal. Mud layers are enhanced in extent by a mud-dependent and in thickness by a generic species. Thus, local biostabilization alters large-scale morphology controlling long term estuarine development.

Published as: Muriel Z. M. Brückner, Lisanne Braat, Christian Schwarz, and Maarten G. Kleinhans (2020), What Came First, Mud or Biostabilizers? Elucidating Interacting Effects in a Coupled Model of Mud, Saltmarsh, Microphytobenthos, and Estuarine Morphology. Water Resources Research, 56. https://doi.org/10.1029/2019WR026945 . 


\subsection{Introduction}

Estuaries are important coastal ecosystems, providing coastal populations with a variety of ecosystems services, such as habitat provision for aquatic plants and animals, regulation of water quality and coastal protection (Barbier et al., 2011; Gill et al., 2001). As transition zones between the river and the sea, estuaries are characterized through dynamically changing morphologies (Dalrymple and Choi, 2007). Varying sediment fractions lead to spatio-temporal differences in sediment transport magnitudes, which affect bed stability through dynamic erosion and deposition patterns (Van Ledden et al., 2004; Van der Wegen and Roelvink, 2012; Dam et al., 2016). The presence of muddy sediments, a mixture of silt and clay $\left(D_{50}<63 \mu \mathrm{m}\right)$, reduces erodibility through cohesive properties that protect the top layer of the bed (Braat et al., 2017; van de Lageweg et al., 2018). Similarly, eco-engineering species, such as microphytobenthos and saltmarsh vegetation, can stabilize bars and shorelines (Austen et al., 1999; Fagherazzi et al., 2012; Kirwan and Megonigal, 2013). Consequently, understanding the interactions between hydrodynamics, sand and mud erosion and deposition and biological communities becomes crucial for the sustainable management of estuaries (e.g. FitzGerald and Hughes, 2019; Wiberg et al., 2019). Here we address the lack of sufficient understanding on the large-scale interactions between biostabilizers and morphodynamics related to sand and mud over decadal time scales.

Mud affects the erosion properties of shorelines and tidal bars (Mitchener and Torfs, 1996; De Jorge and Van Beusekom, 1995). Deposition of muddy sediments strongly depends on hydrodynamics conditions, generally leading to muddy sites in morphologically low-dynamic areas such as the higher intertidal and areas sheltered by vegetation (Braat et al., 2017; Lokhorst et al., 2018). In the lower intertidal and subtidal parts, thin mud layers can be observed close to the surface as a result of seasonal variations in water levels or spring-neap variations, which are often stabilized by microphytobenthos during spring and summer and can be grazed by macrobenthic species or shore birds (Herman et al., 2001; Widdows and Brinsley, 2002; Van der Wal et al., 2008; Mathot et al., 2018; Daggers et al., 2018; van de Lageweg et al., 2018). However, inter-annual preservation of deposited mud in the deeper layers of the bed is often prevented by large floods that erode the sediment in winter (Herman et al., 2001). While mud can have positive effects on bank accretion and stability, impacts on water quality, pollution and enhanced siltation rates can also negatively affect human activities and ecology (Van Ledden et al., 2004; Wang et al., 2015). We require a better understanding of the mechanisms driving formation and preservation of mud layers and their consequences on estuarine planform and morphology.

Eco-engineering effects by saltmarsh vegetation can cause rapid adaptations of the morphology of coastal and estuarine systems (Jones et al., 1994; Holling, 1973; Corenblit et al., 2015; Wang and Temmerman, 2013; Silinski et al., 2016; Lokhorst et al., 2018; Kleinhans et al., 2018). Saltmarshes grow in the intertidal area between mean high (MHW) and mean low water (MLW) where they increase roughness and drag on the flow. Through their roots, stems and leaves they reduce local flow velocities and enhance inundation period (Brückner et al., 2019), promoting accretion of suspended sediments and enhanced local bed elevation (Leonard and Luther, 1995). In estuaries with high sediment availability, accretion rates in 
saltmarshes are governed by allochthonous sediment supply that is controlled by hydroperiod (Temmerman et al., 2004; Fagherazzi et al., 2012; FitzGerald and Hughes, 2019). While hydroperiod is an indicator of the lateral suspended sediment gradient from low marsh to high marsh it also correlates with saltmarsh mortality, as high hydroperiod generally coincides with increased flow velocities causing plant uprooting and reduced oxygen supply (Friedrichs and Perry, 2001; Reed, 1990; Morris and Haskin, 1990; Mendelssohn and Morris, 2002; Morris et al., 2002; D’Alpaos et al., 2006; Hughes et al., 2012; Balke et al., 2016). As the plant's eco-engineering effect depends on its physical attributes, such as plant properties (stem height, flexibility and diameter) and abundance (density), the spatio-temporal changes of saltmarshes linked to mortality and season (phenology) are one main driver of seasonal mud collection (Van der Wal et al., 2011; Silinski et al., 2016). As a result, the dynamics in vegetation growth and mortality define the variability in saltmarsh and mudflat extent and result in refinement of marsh sediments (Schuerch et al., 2014). Even though the mechanism of mud accumulation by already established vegetation is well-known, we lack knowledge whether mud layers facilitate vegetation establishment or vice versa. In systems with limited mud supply the drivers for the formation of mud layers and establishment of saltmarsh vegetation remain entangled. We require a close look at those drivers to understand where mud layer formation or saltmarsh growth precedes the other.

Similarly, microphytobenthos that consists of diverse assemblages of photosynthetic diatoms, cyanobacteria, flagellates, and green algae that grow in the upper layer of illuminated sediments (Steele et al., 2001), further referred to as MPB, contribute to seasonal stabilization of the lower mudflats. The growth of MPB has been linked to bed elevation, emersion time or water content of the sediments (Friend et al., 2003; Lucas et al., 2003; Yallop et al., 2000; Pratt et al., 2014; Ser and Catarino, 1999) and is strongly sediment dependent (Lucas et al., 2003). During their growth period in spring and summer they produce a local biofilm that increases the stability of sediments through secretion of extracellular polymeric substances (EPS) (Paterson, 1994; Vos et al., 1988; Yallop et al., 1994). The biomass of MPB is usually concentrated at the sediment surface, which alters the erosion properties of the sediment in the top layer and thus affects local morphology (De Brouwer and Stal, 2001). This reduction in erodibility can lead to reduced sediment resuspension and transport in the water column (Staats et al., 2001; de Jonge, 2000). A stabilization of 100-500 \% compared to non-colonized sediment has been reported by many authors (Le Hir et al., 2007; Zhu et al., 2019), suggesting the effect of EPS is more important than sediment cohesion (Malarkey et al., 2015). On intertidal flats, consideration of the stabilization by MPB is especially important when predicting morphological change (Zhu et al., 2019). However, we still lack understanding of the long term effects of MPB and how they contribute to anticipated changes in mud availability and bed accretion, including large-scale morphological adaptation of estuaries.

Numerical modeling is a convenient tool to untangle complex interactions between several constituents and subsequently explain emerging patterns that we have yet to fully understand (Fagherazzi et al., 2012; Wiberg et al., 2019). Even though recent morphological models are increasingly rich in processes, only few studies on estuaries or deltas have included sediment mixtures (Edmonds and Slingerland, 2010; Waeles et al., 2007; Braat et al., 2017) and many neglect detailed representations of biostabilizers (Le Hir et al., 2007; Kleinhans et al., 2018). 
However, to be able to disentangle and quantify the drivers that contribute to the formation of mudflats, mud preservation and saltmarsh development, a dynamic, meaning temporally and spatially varying, representation of biostabilizers needs to be combined with an extensive hydro-morphodynamic model that includes sand and mud. This allows an assessment of the role of biostabilization on redistribution of fine sediments and whether biostabilizers improve predictions of mud layer formation. We hypothesize that the inclusion of dynamic vegetation abundances and MPB growth will improve the predictions of mud deposition and, hence, the large-scale morphological development of estuaries.

In this paper, a dynamic eco-morphodynamic model is formulated to represent temporal and spatially varying saltmarsh vegetation through colonization, growth and mortality rules as described in literature. Moreover, the model includes a module that parametrizes seasonal MPB growth to investigate its effect on sediment accretion. Additionally, the model computes sand and mud transport allowing to investigate the feedback between two types of biostabilizers, sediment transport of two grain sizes and morphology that until now have not been combined in previous numerical models. To disentangle the main parameters that promote mud layer formation affected by the presence of biostabilizers, we studied the interactions between dynamics of a generic saltmarsh species, a mud-dependent saltmarsh species and MPB on mud accretion patterns in the Western Scheldt estuary. First, we investigate the eco-morphological causality dilemma, whether ecology facilitates mud settlement or viceversa. This was studied on a tidal bar of a dynamic estuary, where we compared mud and vegetation patterns between two numerical experiments: generic saltmarsh establishment and saltmarsh establishment that requires mud in the bed. Second, we determine the effect of biostabilizers on seasonal- and inter-annual mud preservation to quantify biostabilization effects on long-term morphology. Finally, we analysed the large-scale mud redistribution promoted by generic saltmarsh vegetation and a mud-dependent species to enhance the understanding of the role of biostabilization in estuarine morphological change and to investigate if the trends observed on the tidal bar hold for the estuary scale.

\subsection{Methods}

Our ecological model parametrized spatio-temporal growth of two important biostabilizers, saltmarsh and microphytobenthos (MPB), in combination with mud in the sediment bed. To study the succession of mud settling and vegetation establishment, we further distinguish between a generic saltmarsh species governed by hydroperiod and a mud-dependent species governed by hydroperiod and mud-content. The ecological computations are coupled biweekly to a calibrated 2D-hydromorphodynamic model with sand and mud in Delft3D. We use this eco-morphodynamic model to investigate the mud, vegetation and MPB pattern in the Western Scheldt: while the Western Scheldt estuary serves as a case study to predict large-scale effects of biostabilization on mud redistribution in dynamic estuaries, the tidal bar of Walsoorden allows for a detailed analysis of the feedback between abiotic and biotic stabilization and associated mud and species abundance on bar-scale. At the same time, large data availability on both the tidal bar and the entire estuary allow for validation of our model results and verify our findings derive generalizations for similar systems beyond the Western 
Scheldt estuary. Below, we first present the site and general model set-up before the coupling between the ecological and the hydro-morphodynamic model are outlined.

\subsubsection{Site description}

The Western Scheldt estuary is located in the southwest of the Netherlands (51 41'51'N, 54 0'35"E) and represents the seaward part $(60 \mathrm{~km})$ of the Scheldt Estuary (see Figure 3.1). The well-studied and monitored estuary (e.g. Wang et al., 1999; Winterwerp et al., 2000; Bolle et al., 2010) is a meso- to macro tidal environment with a tidal prism of $2 * 10^{6} \mathrm{~m}^{3}$ (Wang et al., 1999) and a relatively small yearly averaged discharge of $120 \mathrm{~m} 3 / \mathrm{s}$ (De Vriend et al., 2011). The estuary provides access to several harbors with the port of Antwerp being the largest.

The Western Scheldt estuary is characterized by a convergent geometry and contains several vegetated and unvegetated bars that are located between the ebb and flood channels. The dominant species are the pioneer species Spartina anglica and Salicornia ssp. and at later succession stages Aster tripolium (De Vriend et al., 2011). While the mostly sandy estuary contains less than $10 \%$ mud, mud contents over $25 \%$ can be found on the intertidal bars and on the shorelines (van de Lageweg et al., 2018; Braat et al., 2019b). The extent and thickness of existing mud layers have increased in recent years, which was linked to the shift of both subtidal to intertidal and bare to vegetated areas (Wang et al., 2015). During the last decades, heavy dredging and dumping activities have been carried out to provide sufficiently deep channels to access the port of Antwerp (Leys et al., 2006; Plancke et al., 2017). To understand ecological functioning, many studies investigated human induced effects on biodiversity and development of tidal shoals (e.g. Ides et al., 2007; Van der Wal et al., 2008; Van der Wal et al., 2011; Van der Wal and Herman, 2012). The entire Western Scheldt was mapped for specific years as ecotope maps by the Dutch Water Authorities (RWS) that give information on the vegetation cover, different morphological classes and sediment types in a three-to-four-year interval (available on the website of RWS). These maps were reduced to vegetated, muddy and bare cells (see Figure $3.2 \mathrm{~b}$ as an example) and used to validate the model results by comparing vegetation coverage and location of muddy sediments for several years.

The tidal shoal of Walsoorden (blue rectangle in Figure 3.1) formed during the second half of the last century and developed a saltmarsh vegetation cover from the 1990's onwards. The shoal showed dynamic morphological changes throughout the last twenty years, mostly expanding probably because of natural and human-induced accumulation of sediments and a resulting growth in vegetation cover (Cleveringa, 2014; De Vet et al., 2017; Brückner et al., 2019). At the same time, the intertidal area increased and shoal-margin slopes steepened, creating habitat that is less regularly flooded and prone to biodiversity change. Additionally, along with a larger species richness, increased mud content, MPB growth and sediment refinement were observed (Van der Wal et al., 2008; Van der Wal et al., 2011; Daggers et al., 2018). A recent field study showed that large parts of the saltmarsh contain muddy sediment in the top layer (Braat et al., 2019b), indicating a potential sediment sink within the vegetated area. The presence of several biostabilizers and recent accumulation of fines on 


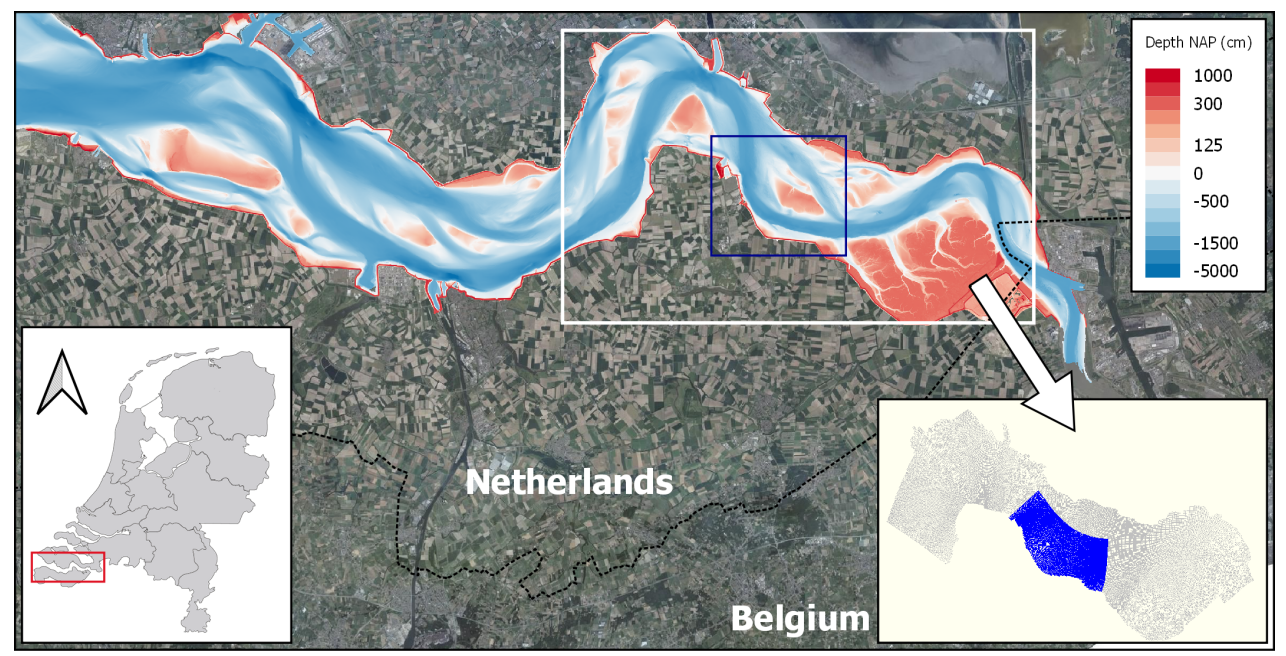

Figure 3.1: The Western Scheldt estuary located in the south-west of the Netherlands (blue-red colors). The medium-scale domain, the tidal shoal of Walsoorden, is marked within the blue rectangle. The model domain is displayed in the lower right corner and includes the area marked in the white rectangle, where the blue grid represents the domain with the small grid sizes.

the shoal make this area an interesting case study to investigate their interactions and draw conclusions about drivers of mud accumulation.

\subsubsection{Model description}

Our eco-morphodynamic model consists of three modules, a 2D depth-averaged hydromorphodynamic model (HM) in Delft3D, and two ecological models simulating the two types of biostabilizers (see Figure 3.3): a dynamic vegetation model and a dynamic microphytobenthos model, both parametrized in MATLAB (version 2016a). A third important biostabilizer, the eelgrass, has been excluded from the study since its distribution in the Western Scheldt estuary is limited and more abundant in the muddy Eastern Scheldt (Suykerbuyk, 2019). Both ecological models consist of separate modules individually coupled bi-weekly with the Delft3D-model to update the ecological parameters and further incorporate their effects on flow in the Delft3D model. Delft3D solves the shallow-water equations (Lesser et al., 2004), sediment transport of sand with the Van Rijn (2004) transport predictor (Van Rijn et al., 2004), mud transport with the Partheniades-Krone formulation (Partheniades, 1965) and morphological development by diffusion after an active layer concept.

\section{The set-up of the eco-morphodynamic model}

The hydro-morphodynamic model is based on a two-dimensional model of the Western Scheldt (the Dutch-Flemish model (Nevla-model)) calibrated for hydrodynamics (Maximova et al., 2009b; Maximova et al., 2009a; Vroom et al., 2015), and optimized for morphology (Grasmeijer et al., 2013; Schrijvershof and Vroom, 2016; van Dijk et al., 2019b) and includes an additional fine mud fraction (Braat et al., 2019b). Waves and stratification linked to salinity are neglected as the estuary is generally well-mixed (Meire et al., 2005; Savenije, 2005) and 

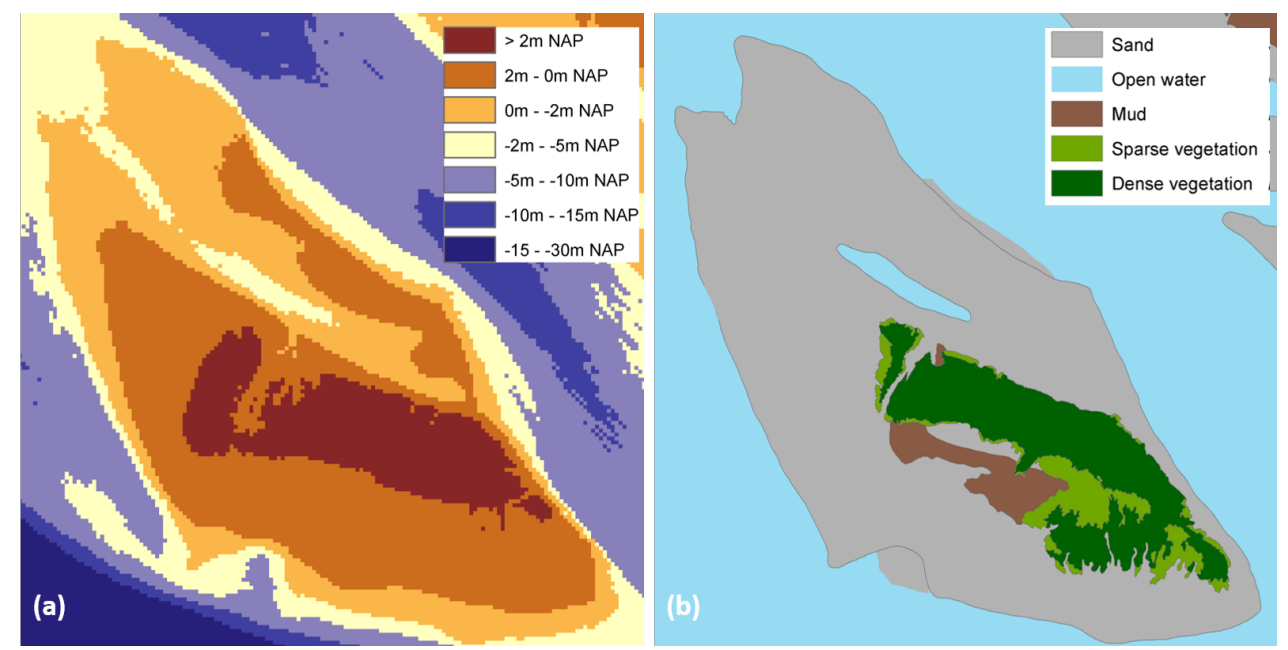

Figure 3.2: Bed elevations (a) and ecotope map (b) for the tidal shoal of Walsoorden in 2015. For our analyses we define bed elevations between mean water ( $0.15 \mathrm{~m} \mathrm{NAP}$ ) and mean high water ( $3.3 \mathrm{~m}$ NAP) of the boundary conditions in 2013 as intertidal area. Mud and vegetation are mainly present at the highest elevations with mud deposits in the sheltered center of the shoal. Braat et al. (2019b) found that sediments within the vegetation are mainly muddy.

the energy by tidal currents dominates sediment transport in the landward part of the estuary (Hu et al., 2018). Furthermore, compaction is not included in the Delft3D model as we look at qualitative analyses of accretion induced by the presence of biostabilizers as compared to abiotic settling. For our analysis we looked at two grid-scales (Figure 3.1). First, we used a decomposed domain of the tidal shoal of Walsoorden to investigate mud accumulation, microphytobenthos growth, and saltmarsh colonization on a fine grid size of approx. 30m (as described in Braat et al. (2019b) and van Dijk et al. (2019b)) (Table 3.3 Run1). Second, we study the MPB, saltmarsh and mud patterns that emerge from their interaction on a coarser grid (100m grid sizes) along the entire Western Scheldt model domain (Table 3.3 Run2). The large domain represents the part between the mouth and the Dutch-Belgian border (see colored shades in Figure 3.1).

The hydrodynamic boundaries consist of a time-series of four representative spring-neap cycles in 2013 based on water level measurements, meaning that the model considers most tidal constituents, storm surges, and discharge and result in sediment input variations as sediment transport is computed using equilibrium sand transport (van Dijk et al., 2019b) and a constant mud input at the river boundary of $0.02 \mathrm{~kg} / \mathrm{m} 3$ (Braat et al., 2019b). To fit the tidal signal into an integer number (Duran-Matute and Gerkema, 2015), the tidal cycle of the dominant M2-tide was reduced to 720 minutes (as in Brückner et al. (2019)). This step was necessary to allow for a constant forcing period of one tidal cycle when upscaling the model for the morphological and ecological computations as described below. To accelerate morphological development, the model included a morphological acceleration factor of 24 that enhanced the computations of erosion and deposition by multiplication. Morphological and ecological time were set equal, which led to one tidal signal (12h) representing 12 days of 
(a)

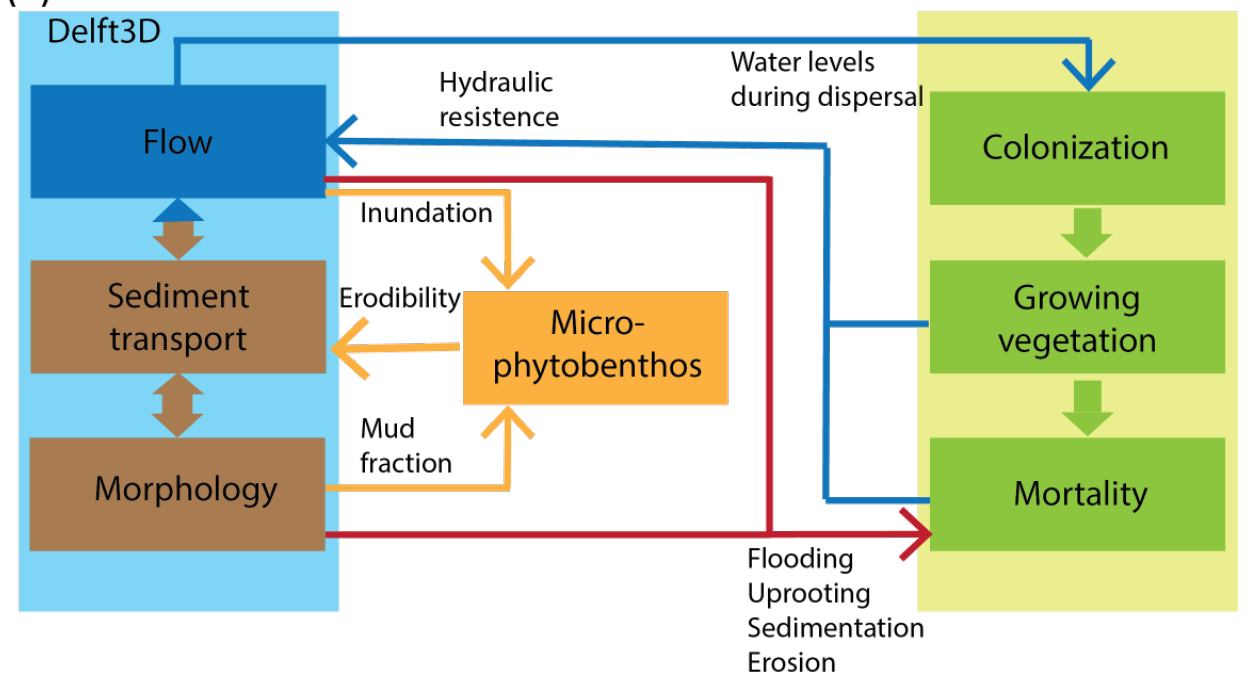

(b) Vegetation height $\left(H_{v}\right)$

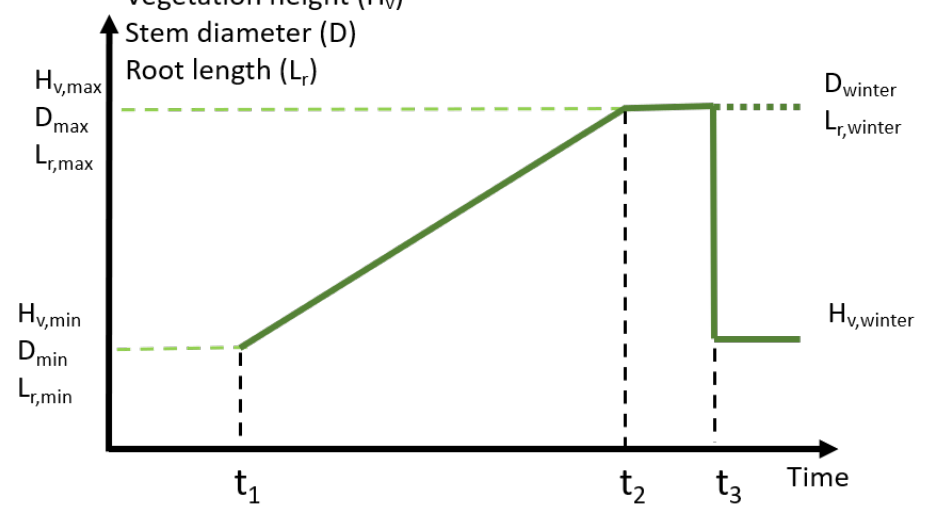

Figure 3.3: A: Concept of the eco-morphodynamic model with its three divisions: hydro-morphodynamic model in Delft3D, dynamic vegetation model and MPB model. The arrows show the interactions between the three divisions. Blue arrows indicate the interactions between hydrodynamics and vegetation establishment and growth, while red arrows show interactions causing mortality. B: Qualitative seasonal growth curve of the height $\left(H_{v}\right)$ and diameter and root length $(D)$ the vegetation throughout each year with $t_{1}$ establishment size, $t_{2}$ maximum size and $t_{3}$ winter size. For the plant diameter and root length the winter size equals the maximum size (dotted line). All values used in the model can be found in the appendix Table B.1. 
Table 3.1: Model parameters as defined in the Delft3D model. More details can be found in van Dijk et al. (2019b) or Braat et al. (2019b)

\begin{tabular}{lcc}
\hline Parameter & value & unit \\
Numerical settings & & min \\
\hline Simulation time ecological year & 20160 & min \\
Numerical time-step & 0.1 & 1/ecological year \\
No. ecological time-steps & 28 & \\
Sand & & $\mathrm{m}$ \\
\hline$D_{50}$ & $2 e^{-4}$ & $\mathrm{~kg} / \mathrm{m}^{3}$ \\
Dry bed density & 1600 & \\
Mud & & $\mathrm{m} / \mathrm{s}$ \\
\hline Settling velocity mud & $5 e^{-4}$ & $\mathrm{~N} / \mathrm{m}^{2}$ \\
Crit. bed shear stress for erosion & 0.2 & $\mathrm{~kg} / \mathrm{m}^{2} / \mathrm{s}$ \\
Erosion parameter & $1 e^{-4}$ & $\mathrm{~kg} / \mathrm{m}^{3}$ \\
Dry bed density & 1000 & $\mathrm{mg} / \mathrm{l}$ \\
Boundary concentration & 40 & \\
Bed settings & & $\mathrm{m}$ \\
\hline Active layer thickness & $5 e^{-2}$ & $\mathrm{~m}$ \\
Max. storage layer thickness & $5 e^{-2}$ & - \\
Morphological acceleration factor & 24 & \\
\hline
\end{tabular}

morphological and ecological development. To fit the spring-neap cycle (14 tidal signals) into one morphological, or ecological, year we applied 28 couplings, leading to 28 ecological timesteps (ETS) with each being one tidal signal of 720 minutes. This led to a total simulation time of 20160 minutes per ecological year. In total, we simulated 12 ecological years for the small domain and 8 years for the large domain. All model parameters are defined in Table 3.1.

\section{Dynamic vegetation model}

To account for vegetation effects in the hydro-morphodynamic model, we used the trachytope approach with the Baptist-formula (Baptist et al., 2007) that allows for several vegetation fractions of different vegetation types and life-stages in one numerical cell. The Baptistformula calculates a net roughness $C[\sqrt{m} / s]$ from a combination of the bed roughness $C_{b}$ $[\sqrt{m} / s]$ and detailed vegetation parameters, such as vegetation height $h_{v}[\mathrm{~m}]$, vegetation density $n\left[m / m^{2}\right.$, and a bulk drag $C_{D}[-]$. Depending on the relative local water depth $h[\mathrm{~m}]$, $C$ is computed as

$$
\mathrm{C}=\left\{\begin{array}{l}
\mathrm{C}_{b}+\frac{\sqrt{g}}{\kappa} \ln \left(\frac{h}{h_{v}}\right) \sqrt{1+\frac{C_{D} n h_{v} C_{b}^{2}}{2 g}}, \text { if } \mathrm{h} \geq h_{v} \\
\mathrm{C}_{b}, \text { if } \mathrm{h}<h_{v}
\end{array}\right.
$$

with $g$ is gravity $\left[\mathrm{kg} / \mathrm{s}^{s}\right], \kappa=0.41[-]$ von-Kármán constant and $C_{b}=25[\sqrt{\mathrm{m}} / \mathrm{s}]$, which is derived from the Manning of the vegetated bars of 0.028 and a water depth of $0.1 \mathrm{~m}$. To compensate for higher local sediment transport induced by increased $C$, an additional flow resistance $-\lambda / 2^{\star} u^{2}$ is included in the flow solver, where $\lambda$ is defined as 


$$
\lambda=\left\{\begin{array}{l}
C_{D} n \frac{h_{v}}{h} \frac{C_{b}^{2}}{C^{2}}, \text { if } \mathrm{h} \geq h_{v} \\
C_{D} n, \text { if } \mathrm{h}<h_{v}
\end{array}\right.
$$

Finally, for each vegetation fraction present in each cell, both $\lambda$ and $C$ are weighted according to their relative coverage $f_{i}$

$$
C_{\text {total }}=\sum_{i} f_{i} C_{i}
$$

and

$$
\lambda_{\text {total }}=\sum_{i} f_{i} \lambda_{i}
$$

To investigate the effect of saltmarshes on mud accumulation and bed accretion we tested both a generic saltmarsh species as in Brückner et al. (2019) and a mud-dependent species that only colonizes cells with a mud fraction in the top layer larger than $40 \%$ (Van Ledden et al., 2004) that is similar to the critical mud fraction for cohesion. At each coupling time-step, the results of the Delft3D-model are fed into the dynamic vegetation model to calculate the new vegetation parameters. Below we briefly describe the vegetation rules that determine species establishment, growth and mortality. For more detail on the dynamic vegetation model please see Brückner et al. (2019).

The dynamic vegetation model includes colonization, growth, aging and mortality rules based on literature (Brückner et al., 2019). Colonization is defined at the beginning of each year while vegetation growth is defined by a seasonal increase in biomass, based on height and stem diameter, throughout the ecological year. Aging is accounted for by parametrization of a second life-stage for plants that survive their first year, consequently reaching larger maximum plant sizes and higher resilience to stresses. Mortality induced by hydro-morphodynamic stresses reduces the vegetation fraction in a cell and makes room for new seedling establishment.

Establishment occurs at the beginning of each ecological year. For the generic species, cells that are located in the intertidal area (flooded and subsequently dried during one ETS) are filled with an initial fraction of 0.4 . The mud-dependent species additionally requires a 40\%-mud fraction in the top bed layer, which is characteristic of Spartina (Huckle et al., 2000). After initial settling in $t_{1}$, vegetation grows linearly until the ecological summer $\left(t_{2}\right)$, remains constant until autumn $\left(t_{2}-t_{3}\right)$ and above-ground biomass decays at the beginning of winter $\left(t_{3}\right)$ (see Figure 3.3). After surviving their first year, the vegetation enters a new lifestage with larger sizes and higher resilience and regrows. At the same time, new seedlings can establish as long as the maximum fraction of 1 in the cells is not exceeded. The parameters for the vegetation growth can be found in the appendix Table B.1. Vegetation cover can decline through mortality that is calculated every coupling interval. Mortality rules include dying due to inundation period, uprooting by velocity, erosion of roots and burial of above-ground biomass. Hereby, inundation period and velocity cause gradual, linear mortality depending on pressure strength while burial and scour immediately remove the entire 
fraction if a threshold values is exceeded. The mortality parameters are summarized in Table B. 2 in the appendix.

The dynamic vegetation model is mortality-driven, which means that species can settle with an initial fraction, which represents patch-density rather than individual plant-density and makes rhizomal growth of e.g. Spartina anglica irrelevant. In suitable cells, every year new fractions are added to the cell which account for lateral expansion or seedling establishment, leading to the saltmarsh growth that is observed in reality (Brückner et al., 2019). Mortality is a percentage of the initial fraction, which allows for constant die-off rates independent of the plant fraction present. This strategy allows us to model several ecological concepts of saltmarsh vegetation, both rhizomal expansion and single seedling establishment, which leads to dense vegetation higher up the marsh and single species surviving more difficult abiotic conditions at lower elevations (Brückner et al., 2019).

\section{The microphytobenthos model}

The effect of MPB growth on mud stabilization was investigated for both domains. Linked to the secretion of extra-polymeric substances (EPS) MPB stabilize the sediment and reduce local erosion (van de Koppel et al., 2001). We account for this effect by an alteration of the resuspension properties of the mud fraction in cells where MPB grow. Hereby, we assume that MPB live on top of the sediments altering the critical bed shear stress for erosion $\tau_{c r, e}$ of the mud while the erosion parameter $M\left(\mathrm{~kg} \mathrm{~m}^{-2} \mathrm{~s}^{-1}\right)$ remains unchanged. This directly affects the erosion flux $E_{m}$ of the mud between the bed and the water column $\left(\mathrm{kg} \mathrm{m}^{-2} \mathrm{~s}^{-1}\right)$ in the Partheniades-Krone formulations (Partheniades, 1965) as

$$
E_{m}=\operatorname{MS}\left(\tau_{c w}, \tau_{c r, e}\right)
$$

with $\tau_{c w}$ maximum shear stress at the bed $\left(\mathrm{N} \mathrm{m}^{-2}\right)$ and $S$ erosional step function. This equation is used for the computations of mud erosion and deposition while the van Rijn (2004) transport predictor computes sand transport.

Since MPB in the Western Scheldt grows seasonally under warm temperatures and sufficient sunlight (Herman et al., 2001) we defined a growth period of ten ecological time-steps. In contrast to the dynamic vegetation model, newly establishing MPB was calculated each coupling interval with the Delft3D model (every ETS) as a function of inundation period $i$ and mud fraction $f_{m u d}$ in the top layer and was added to the already established MPB cover $M P B_{\text {pre }}$ leading to increasing MPB cover $M P B_{\text {est }}$ throughout the growth period

$$
M P B_{\text {est }}=f\left(\mathrm{i}, f_{\text {mud }}\right)+M P B_{\text {pre }}
$$

indirectly selecting sheltered areas with limited erosional and depositional processes (Herman et al., 2001). The colonization thresholds can be found in Table 3.2.

In cells where MPB was present, the critical shear stress of the mud fraction was increased by a factor of 4 from $0.2 \mathrm{~N} \mathrm{~m}^{-2}$ to $0.8 \mathrm{~N} \mathrm{~m}^{-2}$ as reported in Le Hir et al. (2007) that provide a literature review of the effects of biostabilizers on erodibility. Consequently, the microphytobenthos model was driven by colonization, which accounted for a gradual spread of the MPB 
Table 3.2: Colonization thresholds for binary MPB establishment.

\begin{tabular}{lcc}
\hline Microphytobenthos & min. threshold & max. threshold \\
\hline inundation period $^{a}$ & 0.35 & 0.5 \\
mud fraction $^{b}$ & 0.3 & \\
\hline${ }^{a}$ Daggers et al. (2018); van de Koppel et al. (2001) & & \\
${ }^{b}$ Widdows and Brinsley (2002) & &
\end{tabular}

in summer when water levels are reduced. As a result, no cell-specific growth or mortality through hydro-morphodynamic pressures or grazing were considered (Le Hir et al., 2007). At the end of the growth season, MPB was entirely removed and the critical bed shear was set to its abiotic value in all cells.

\subsection{Results}

To quantify interactions between mud layers, saltmarsh growth, and microphytobenthic stabilization, our eco-morphodynamic model is based on a calibrated and optimized two-dimensional hydro-morphodynamic model combined with a dynamic and interactive representation of vegetation and microphytobenthos (MPB).We ran the model on a medium-scale grid of the tidal bar of Waalsoorden to investigate the interactions between the two biostabilizers and seasonal mud layer formation and preservation. A large-scale grid of the Western Scheldt estuary allowed to investigate the large-scale effect of biostabilization on redistribution of mud and consequences for mud layer thickness (see Figure 3.1).

Using the medium-scale grid, we first validate and quantify the spatial representations by our model compared to the ecological development over several years in the ecotope maps $(2004,2008,2012)$ to investigate decadal saltmarsh establishment and MPB growth on barscale. To gain insights into the feedbacks between mud and saltmarsh vegetation growth, we compare vegetation pattern for the generic and mud-dependent species as well as to a run with only sand. Second, we disentangle the effect of several biostabilizers on mud layer formation by comparing a mud patterns resulting from generic or mud dependent saltmarsh colonization and presence of MPB (see Table 3.3 Run1-scenarios). Here we distinguish in a) seasonal mud layers with a thickness of smaller than $10 \mathrm{~cm}$ (Herman et al., 2001) that are washed away between years and have ecological but insignificant morphological effects and b) mud preservation defined as layers reaching $10 \mathrm{~cm}$ or larger thicknesses that are preserved in the lower layers of the bed and become part of the morphology.

Finally, we look at the mud distribution along the Western Scheldt estuary to predict largescale morphological change and subsequently investigate the influence of the generic saltmarsh and a mud dependent saltmarsh to quantify their effects on the large-scale morphological development of estuaries (Table 3.3 Run2-scenarios). We compare trends of seasonal mud and preserved mud layers to make generalization on large-scale pattern of mud and biostabilizers and their interactive effects. 
Table 3.3: Model scenarios based on initial bathymetries, years of simulation time, grid cell sizes, and the years of the ecotope maps that the model results were compared to. We investigated the ecomorphodynamic model over 12 years morphological development (2000, 2004, 2008, 2012) for the generic saltmarsh with only sand (Run1_GVegSand) as well as sand and mud (Run1_GVeg), mud-dependent saltmarsh (Run1_MVeg), microphytobenthoss (Run1_MPB), the combination of generic saltmarsh and MPB (Run1_GVegMPB) and reference scenarios without biostabilizers (Run1_Ref). Model runs for a coarser grid spanning the entire estuary (Run2-scenarios) were conducted to investigate large-scale effects of generic and mud-dependent saltmarsh vegetation (SM) on mud accretion.

\begin{tabular}{lcccc}
\hline Model scenario & Ecol. sim. time & Ecotope maps & Grid cell size & Biostabilizer \\
\hline Run1_GVegSand & 12 & $2004,2008,2012$ & $\sim 16 m \times 27 m$ & generic SM \\
Run1_GVeg & 12 & $2004,2008,2012$ & $\sim 16 m \times 27 m$ & generic SM \\
Run1_MVeg & 12 & $2004,2008,2012$ & $\sim 16 m \times 27 m$ & mud-dependent SM \\
Run1_MPB & 12 & $2004,2008,2012$ & $\sim 16 m \times 27 m$ & MPB \\
Run1_GVegMPB & 12 & $2004,2008,2012$ & $\sim 16 m \times 27 m$ & generic SM + MPB \\
Run1_Ref & 12 & $2004,2008,2012$ & $\sim 16 m \times 27 m$ & - \\
\hline Run2_GVeg & 8 & 2008 & $\sim 50 m \times 180 m$ & generic SM \\
Run2_MVeg & 8 & 2008 & $\sim 50 m \times 180 m$ & mud-dependent SM \\
Run2_Ref & 8 & 2008 & $\sim 50 m \times 180 m$ & - \\
\hline
\end{tabular}

\subsubsection{Mud settling and biostabilizers}

To investigate the interaction between the spatial distribution of saltmarsh vegetation and mud we compared the results of the vegetation pattern of all scenarios of Run 1 in (Figure 3.4). A comparison between the generic saltmarsh species cover on only sand (Figure 3.4b) with a scenario with mud (Figure 3.4c) did not show a significant difference in cover location, implying that the mud accumulation did not affect generic saltmarsh growth significantly. In comparison with the ecotope maps that show an increase in vegetation cover through time, the generic saltmarsh species (Figure 3.4c) overpredicted total cover towards the northwest of the bar by predicting nearly constant growth through time. On the other hand, the mud-dependent species underpredicted coverage as mapped in the south-west of the bar, but showed better correspondence in saltmarsh pattern over time (Figure 3.4d). Figure 3.4e represents the mean growth period that $\mathrm{MPB}$ was present during the growth period showing main growth on the lower mudflats especially at the southwestern tip of the bar as has already been reported by previous studies (Van der Wal et al., 2008; Daggers et al., 2018). A combination of the generic saltmarsh and MPB (Figure 3.4f) led to increased MPB coverage at the edges of the bar. Figure 3.4 illustrates that vegetation and microphytobenthos growth locations on Walsoorden can locally be affected by the presence of mud.

The generic and mud-dependent vegetation type both led to different vegetation and mud pattern on the bar. The generic species (Figure 3.5C) largely covered the bar in year 4 and only spread partly during the remaining simulation time, while the mud-dependent species gradually expanded in cover with time (Figure 3.5D). The mud cover increased with increasing vegetation cover in the vegetated cells for both vegetation types, leading to mud fractions larger than 0.5 in the top layer, while adjacent to the saltmarsh mud in the bed only appeared in lower fractions of around 0.25 . This increase in mud on the bar led to a gradual spread of the mud-dependent species, which enhanced settling within young patches and initiated a positive feedback between mud layers and saltmarsh growth (Figure 3.4d). Thus, saltmarsh growth resulted in high mud contents covering large parts of the bar for the vegetated scenar- 


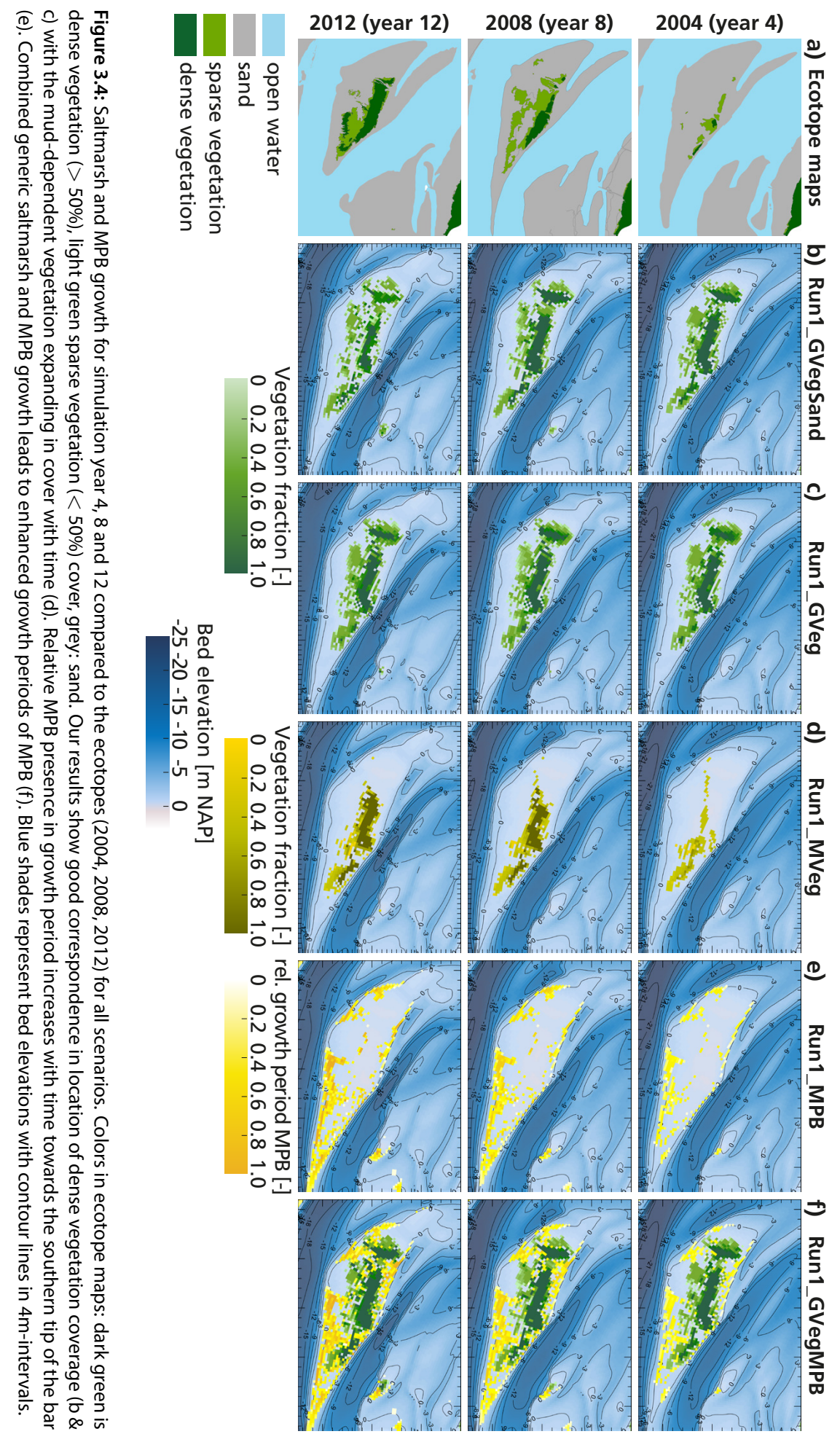


ios. In contrast, the reference scenario without vegetation (Figure 3.5B) showed similar mud fractions at the southern tip as the vegetation scenarios while the centre and western part of the shoal were covered with lower mud fractions in the top layer. As a result, under hydrodynamically calm conditions mud can settle without saltmarsh vegetation, whereas vegetation promotes mud layer formation at exposed areas where it acts as a local sediment sink.

In contrast to the saltmarsh scenarios, the scenario with MPB (Figure 3.5D) showed similar mud locations as the reference scenario while a scenario with both the generic saltmarsh and MPB (Figure 3.5F) resembled the results of Run1_GVeg. As the MPB required sufficient mud in the top layer it was mainly found at south-western tip of the bar where prior mud settling occurred (Figure 3.4E) and showed limited effects on mud area extent. Interestingly, the locations where MPB were present do not necessarily co-occur with the highest mud fraction in the top layer, suggesting that there is a more complex feedback between biostabilization by MPB and mud.

The performance of the mud model, as evaluated by the ecotope maps, was significantly improved by the presence of vegetation (Figure 3.5 bars). The generic vegetation scenario improved the predictions for cells that contained a substantial amount of mud compared with the reference scenario by over $50 \%$. Similarly, the mud-dependent species increasingly enhanced predictions over time while MPB resulted in limited improvements. As we started from a bed without mud, the generic vegetation enhanced predictions especially in the first years of the simulation and became less important with accumulation of the mud in the bed whereas the mud-dependent species enhanced predictions with increasing cover and time. Best predictions were obtained when both saltmarsh vegetation and MPB were present. In general, this shows that predictions of surface mud are improved when vegetation establishment and growth are included.

We investigated the effects of biostabilization on seasonal mud accretion by comparing mean mud accretion for all scenarios that include mud over one ecological year (Figure 3.6). For MPB, mud accretion was greatest during its growth period and low water levels and reduced with increasing water levels towards the end of the year. For the scenarios including saltmarsh vegetation, mud accretion was greatest induced by a combination of low plant sizes and high water levels at the beginning and end of the year, possibly due to enhanced inundation periods on the bar. On the other hand, the combination of low water levels and high biomass during growth season prevented flooding of the marsh during summer, leading to lower accretion rates than the reference scenarios. As a result, seasonal variations in vegetation size had negative impacts on mud accumulation during growth season while low vegetation biomass and high water levels in winter led to largest accretion through both enhanced trapping and protection of the existing surface mud. The combination of both the generic saltmarsh and MPB led to enhanced accretion along the entire ecological year. Interestingly, in this scenario accretion during the growth period of MPB was lower than when only MPB was present but promoted larger sedimentation rates towards the end of the year.

\subsubsection{Mud preservation and the role of biostabilization}

To better understand the influence of biostabilizers on mud preservation in the bed, we compared mud thickness among five scenarios (Figure 3.7). The thickness of mud layers was 


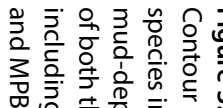

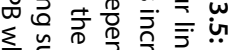

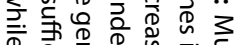

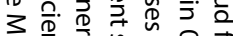

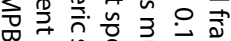

을

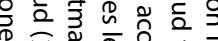

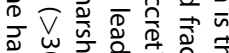

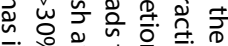

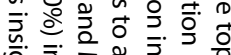

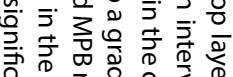

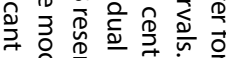

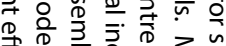

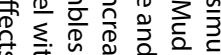

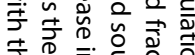

苍

กิ

웅웡

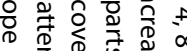

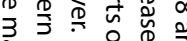

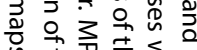

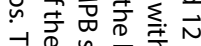

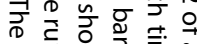

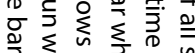

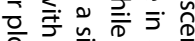

웅

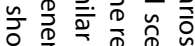

经

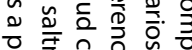

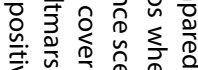

ब

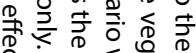

$\stackrel{2}{7} \rightarrow \frac{1}{D} \leq$

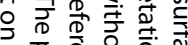

융

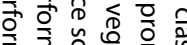

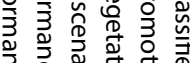

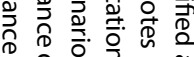

울충

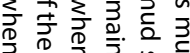

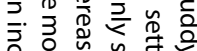

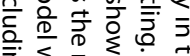

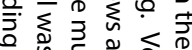

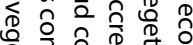

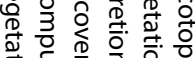

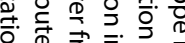

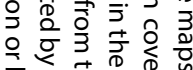

웅 응

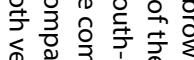

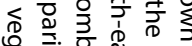

需

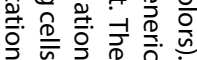
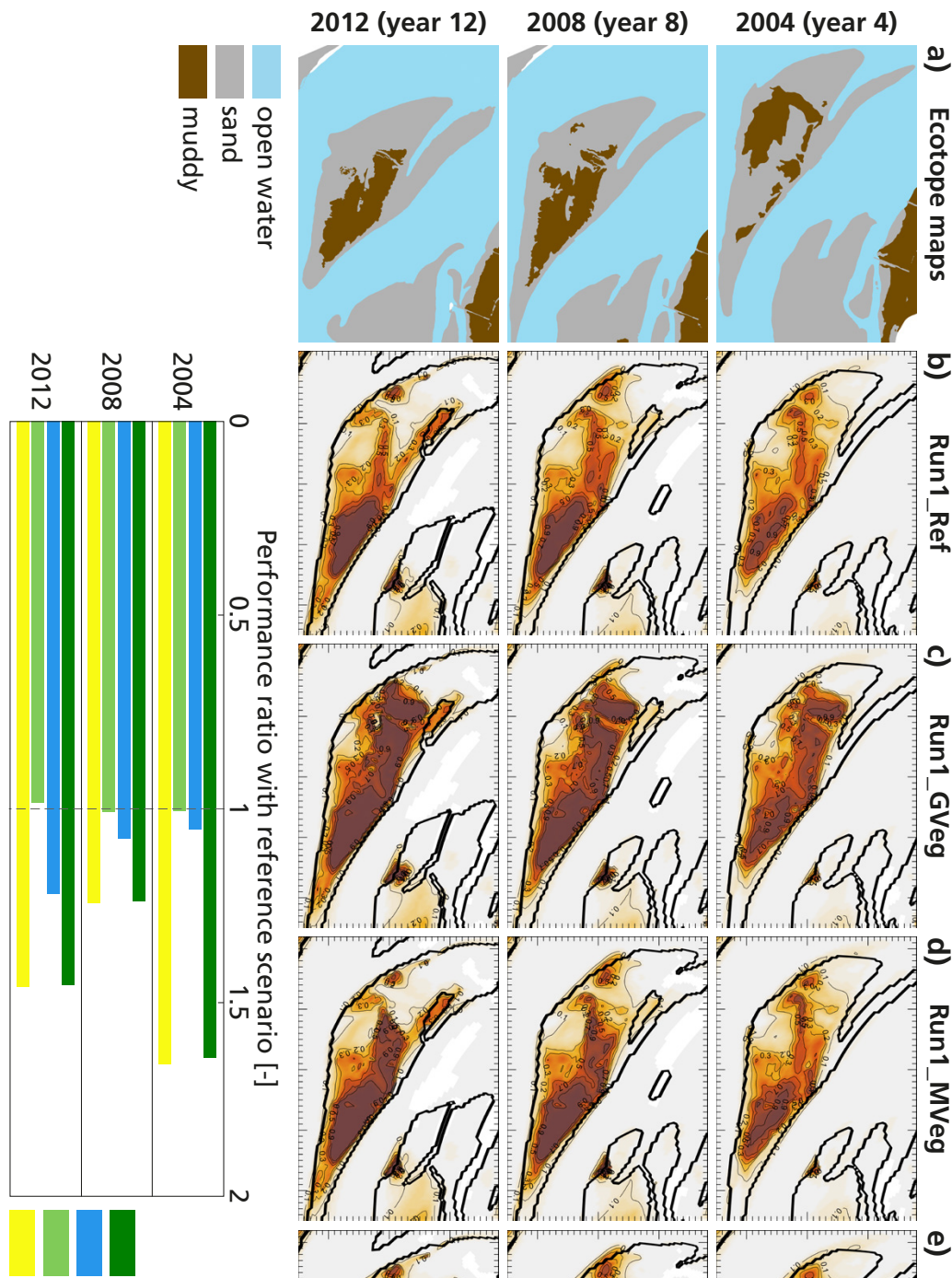

0330
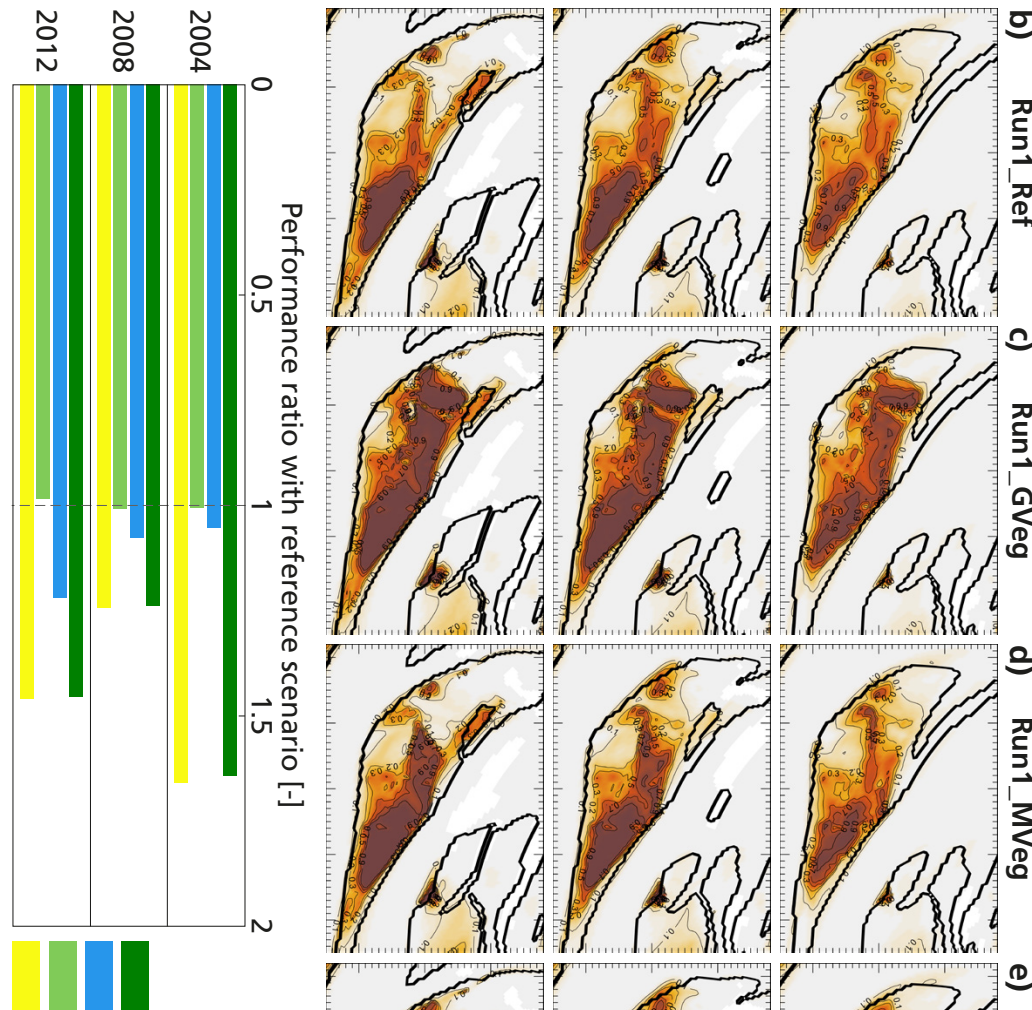

通亩通迹

离

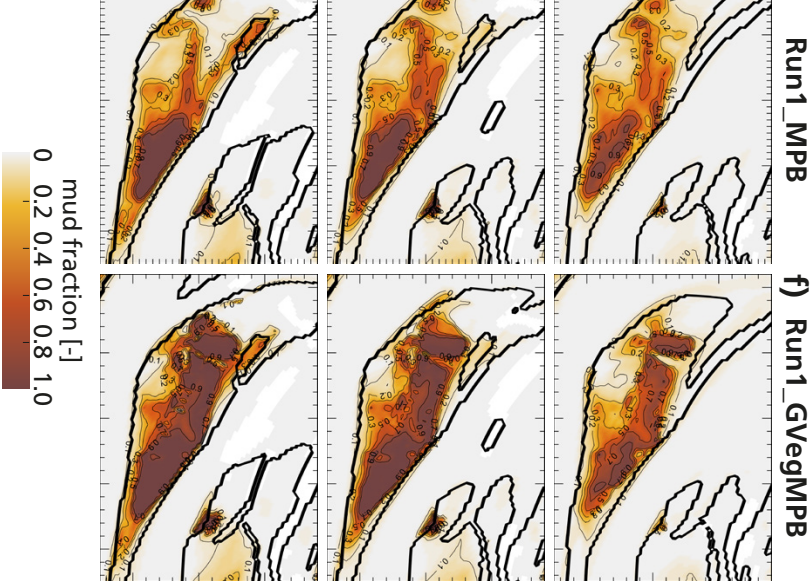




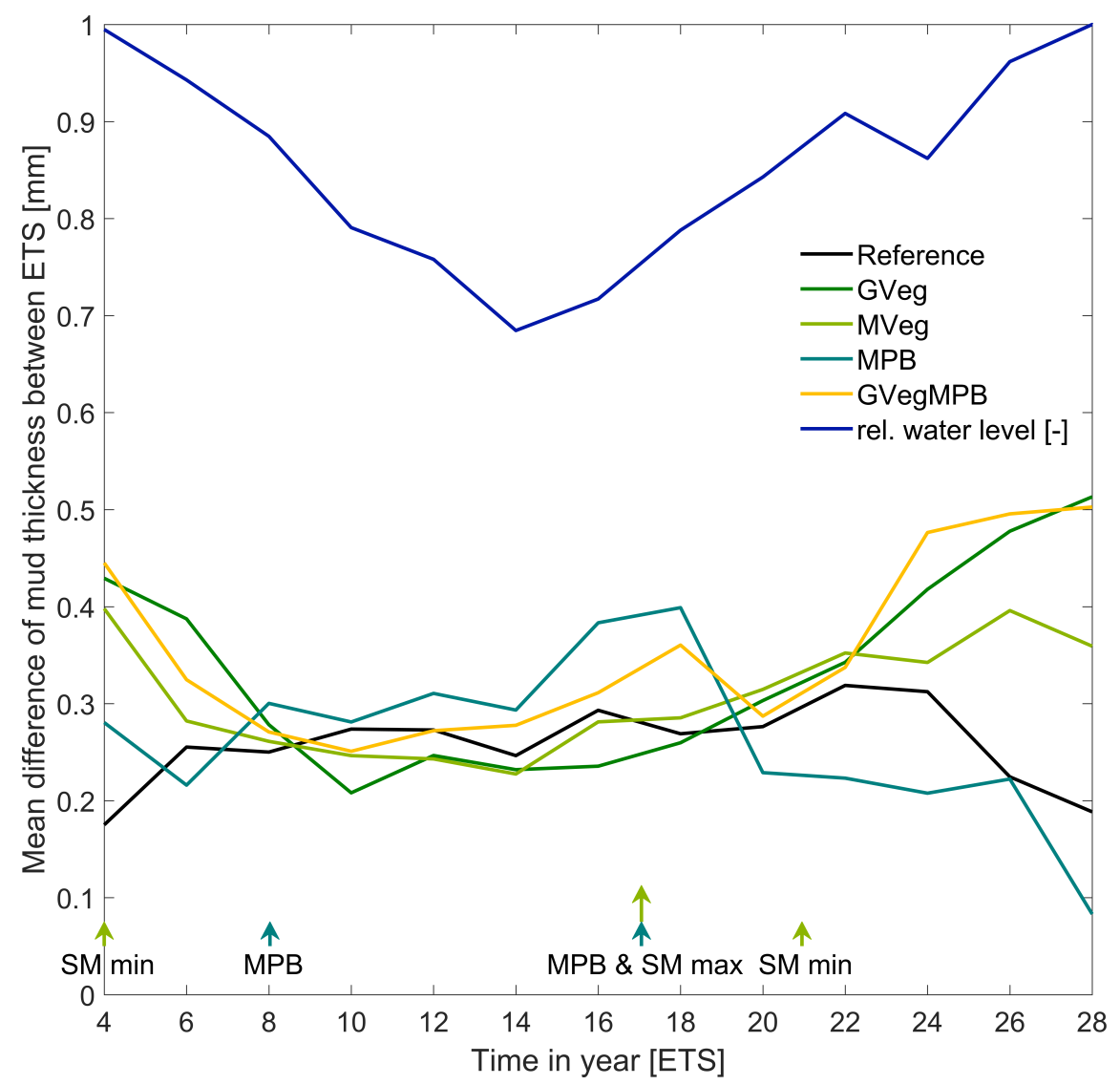

Figure 3.6: Seasonal trapping efficiency for intertidal area (above MLW = -2.5 NAP) averaged over the last four years of simulation time is compared to the relative high water level at the boundaries over one ecological year (one hydrological spring-neap cycle), showing mud accumulation for all scenarios. Arrows indicate qualitative plant sizes for the saltmarsh growth cycle (SM) and start and end of the growth period of MPB within the ecological year. In contrast to the reference scenario, the accretion under biostabilization is governed by a combination of the variations in water level and seasonal growth: While MPB clearly enhances trapping during its growth period vegetation promotes largest trapping at the beginning and end of the year with reduced accretion during its growth season. The combination GVegMPB enhances accretion throughout the entire ecological year. 
enhanced by the presence of saltmarsh vegetation compared to the reference scenario with only mud. Mud preservation was strongest at the southern tip and also the only part of the bar where mud settled without vegetation cover (Figure 3.7-1). Especially in the center and western part of the bar, mud could only settle within vegetation patches and thickness increased over the period that vegetation was present (compare Figure 3.7-2 and 3.7-3). This indicates that shielding makes the saltmarsh the driver of mud accretion on top the shoal of Walsoorden that allows for preservation in the lower layers of the bed.

Cross-sectional analysis revealed higher absolute accretion thickness by the three biostabilizing species (Figure 3.7-2, 3.7-3, 3.7-4 and 3.7-5). The transects (displayed in Figure 3.7-1) are representative for several bed elevation gradients and vegetation densities, showing that relative mud accretion was enhanced at higher elevations and in vegetated cells. This in turn led to an increase in bed elevation and preserved a large part of the available fine sediment in the first few top decimetres of the bar. However, the accretion was not directly dependent on the vegetation density of the computational cell, showing accumulation in but also next to the densely colonized cells. The mud-dependent species showed the same mud accretion pattern. Mud layer thickness was observed at intermediate elevations for transect 1 in all scenarios (coordinate 64.5-65 km), showing that mud preservation not necessarily correlated with bed elevation. MPB presence showed similar trends as the saltmarsh vegetation, where accretion occurred at high elevations and in cells adjacent to colonized cells (Figure 3.7-4a-h). Mud thickness and vegetation fractions increased when both vegetation and MPB were combined (Figure 3.7-5q-t), suggesting a positive feedback that enhanced saltmarsh abundance when MPB were present. Consequently, and in contrast with the results from Figure 3.5 showing that top layer mud fractions were enhanced within colonized cells, mud preservation in the lower layers of the bed was governed by local effects at bar-scale that emerged from a combination of local bed elevations and biostabilization.

\subsubsection{Vegetation effects along the estuarine gradient}

Similar to the processes on the tidal bar of Walsoorden we observed enhanced mud accretion by vegetation presence along the entire Western Scheldt estuary. Vegetation occurred at the high elevations on the shoals and at the shores (Figure 3.8A1 and A2). Hereby, vegetation densities were largest toward the highest parts of the estuary. Mud (Figure 3.8B1 and B2) accreted mainly on the higher mudflats at the edges of the estuary while only limited deposition was observed in the channels and on the bars. Smaller mud fractions occurred in hydrodynamically active areas while large mud fractions were exclusively observed in colonized areas. The presence of saltmarsh vegetation promoted mud settling on the bars and along the sides of the estuary. The mud difference maps (Figure 3.8C1 and $\mathrm{C} 2$ ) show that vegetation increased mud settling (Hoge Platen, Walsoorden, Saeftinghe). However, at the highest areas along the estuary fringes accretion rates were lower than in the reference scenario as the vegetation slowed down the flow, causing settling closer to the channels with limited fine sediment transport towards the shores. The presence of the mud-dependent species led reduced fractions of mud in the top layer.

A more detailed analysis of the trends observed in Figure 3.8 reveals that the total mud area for thin layers reduced towards higher elevations while extent of thick mud layers increased 


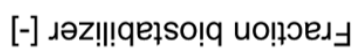

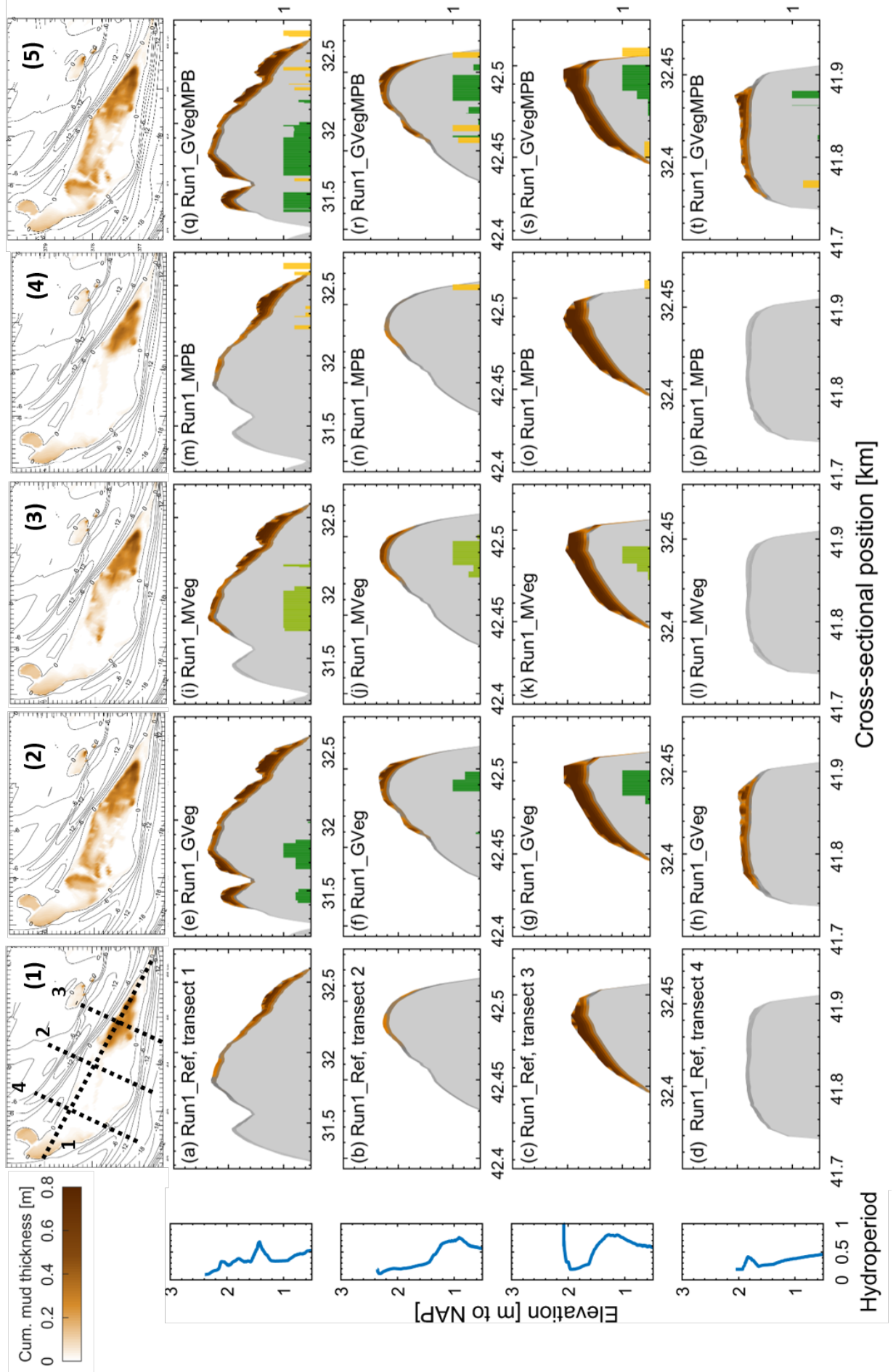

㝘

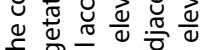

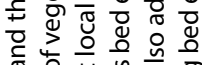
क

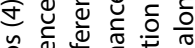

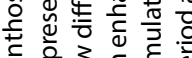

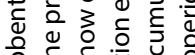

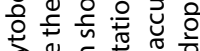

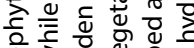
年

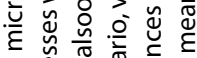

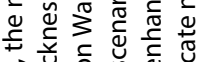

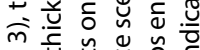

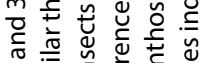

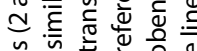
을 뒁 喝.

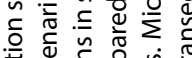

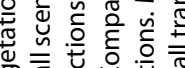
可完它讨

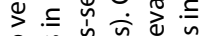

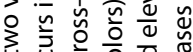
论

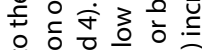

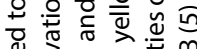

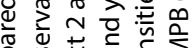
을 苟

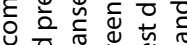

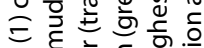
을 离 응 苑 㟧

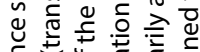
要

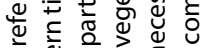

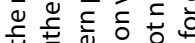

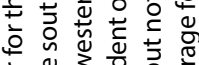

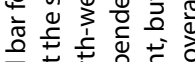

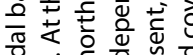

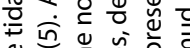
要

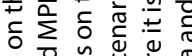
ᄃ 웡 要

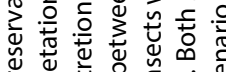

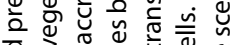

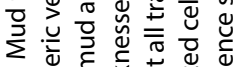

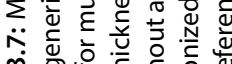

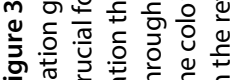



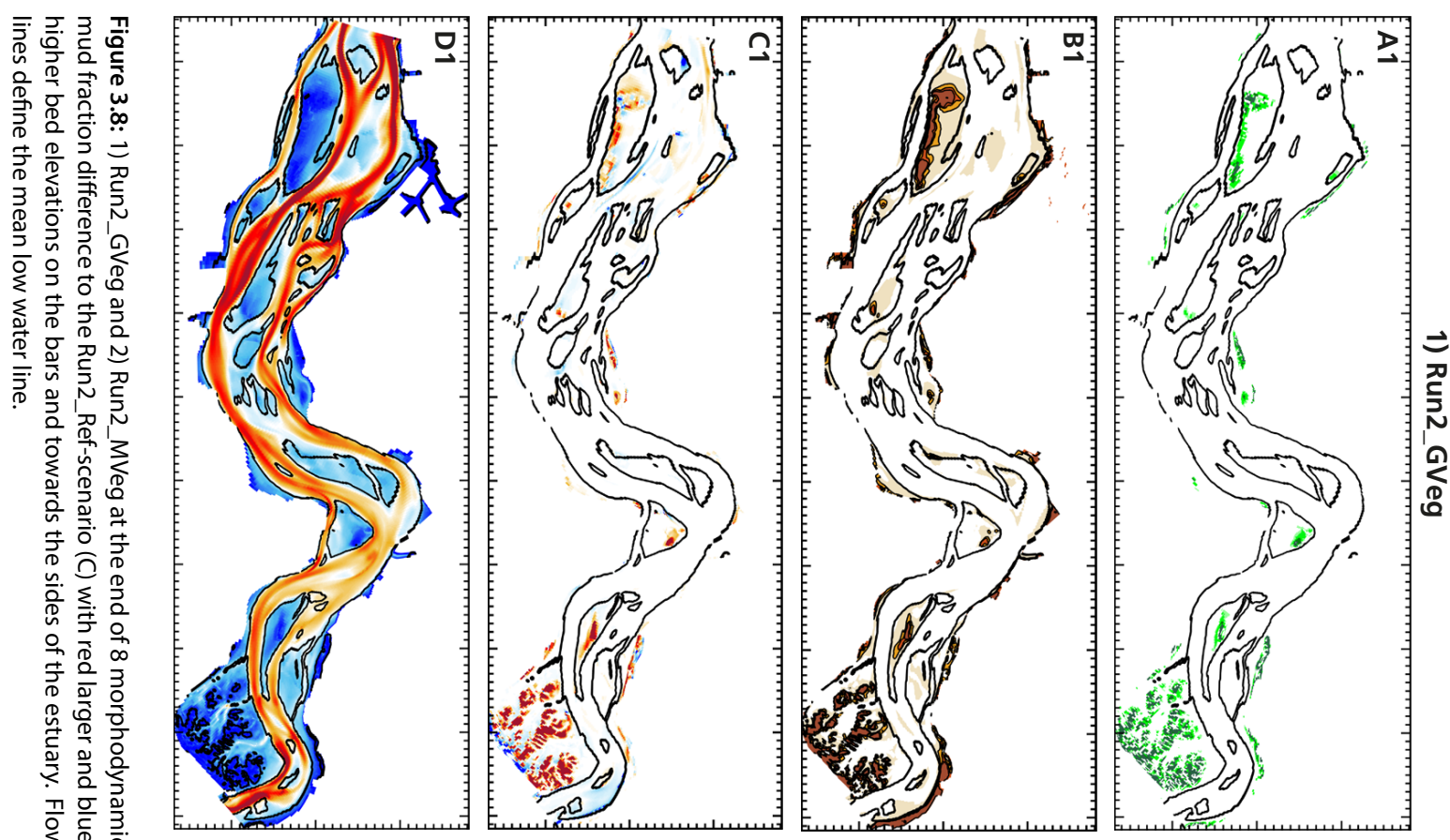

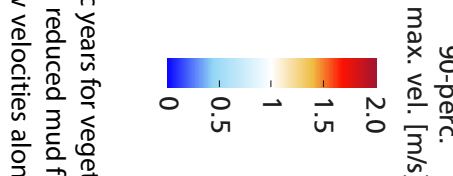
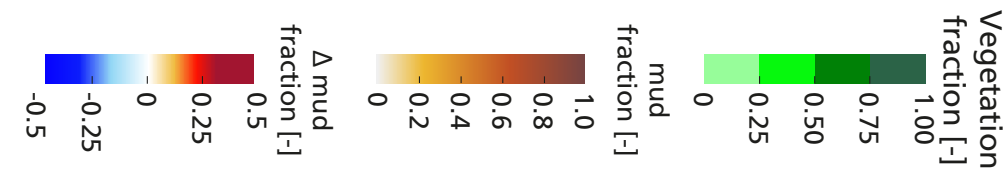

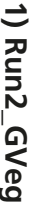
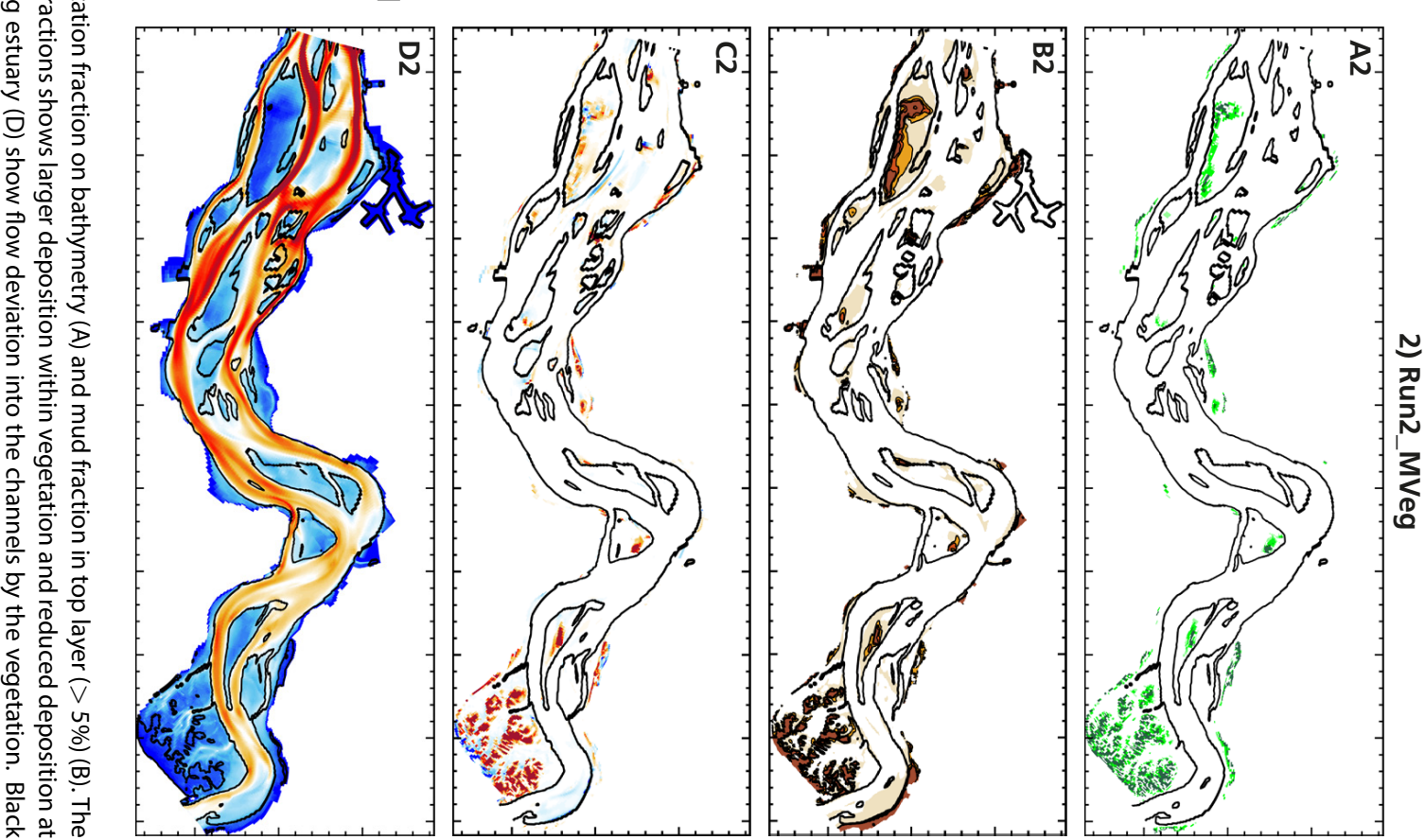
(Figure 3.9). Once vegetation was introduced, the mud layer extent increased for both thick and thin layers with distinct peaks at higher intertidal elevations (GVeg \& MVeg). Hereby, thick layers were found at higher elevations than the thin layers. However, the settling of mud within the vegetation led to reduced mud availability at the highest elevations, reducing mud extent at high bed elevations where the largest vegetation cover occurred.

Interestingly, the generic saltmarsh enhanced thick mud layers close to the vegetation edge compared to a mud-dependent species linked with enhanced sedimentation within the sparse vegetation at the marsh edge. On the other hand, the mud-dependent species was able to increase thin mud layer extent along large parts of the intertidal domain leading to the establishment of new mud layers away from the marsh. This can be linked with the gradually expanding saltmarsh already observed in figure 3.4 allowing for more gradual sedimentation with expanding plant cover. As a result of the modification of the mud pattern by vegetation, the area of the thin and thick mud layers in the estuary was increased by $15-25 \%$ and $55 \%$ of the reference run, respectively, (Figure 3.9A \& B).

\subsection{Discussion}

Spatio-temporal variations in mud deposition, saltmarsh and microphytobenthos (MPB) growth govern the morphology of tidal systems by stabilization of shorelines and tidal bars that define multi-channel systems in estuaries (Braat et al., 2017; Allen, 2000; Temmerman et al., 2003; Le Hir et al., 2007). To be able to understand the feedback between biostabilization, mud layer formation and morphology, a detailed eco-morphodynamic model is required that accounts for eco-engineering effects on dense temporal and spatial scales (Brückner et al., 2019). Models that simplify saltmarsh growth and sediment settling as monotonously increasing are only applicable in systems with unlimited suspended sediment supply and where saltmarshes matured to a cohesive cover that leads to sheet flow above the canopy with constant sedimentation rates (Fagherazzi et al., 2012). For the first time, this model enables us to study the feedbacks between differences in mud layer formation and biostabilization to draw conclusions on the effects on morphology in a dynamic, large-scale estuarine system.

The models including the generic saltmarsh and both the generic saltmarsh and MPB improve predictions of mud locations by more than $50 \%$ compared to the reference run without biostabilization, as evaluated by the ecotope maps. The performance reduces with simulation time as the reference scenario accumulates mud with simulation time. On the other hand, a mud-dependent species leads to improved model predictions over time as mud and vegetation spread gradually, which increases performance in the later years. Overall, this shows that including saltmarsh vegetation into hydro-morphological computations enhances mud predictions depending on the initial state of the model and the choice of the vegetation. However, MPB does not enhance predictions of mud layer formation.

Our model computes sediment transport and morphodynamics by state of the art relations, and includes literature-based seasonal saltmarsh and microphytobenthos (MPB) dynamics that predicts patterns comparable to field data (Figure 3.4 and 3.5). The simulation results of Run1_MPB show similar locations of MPB growth as previously reported in lit- 


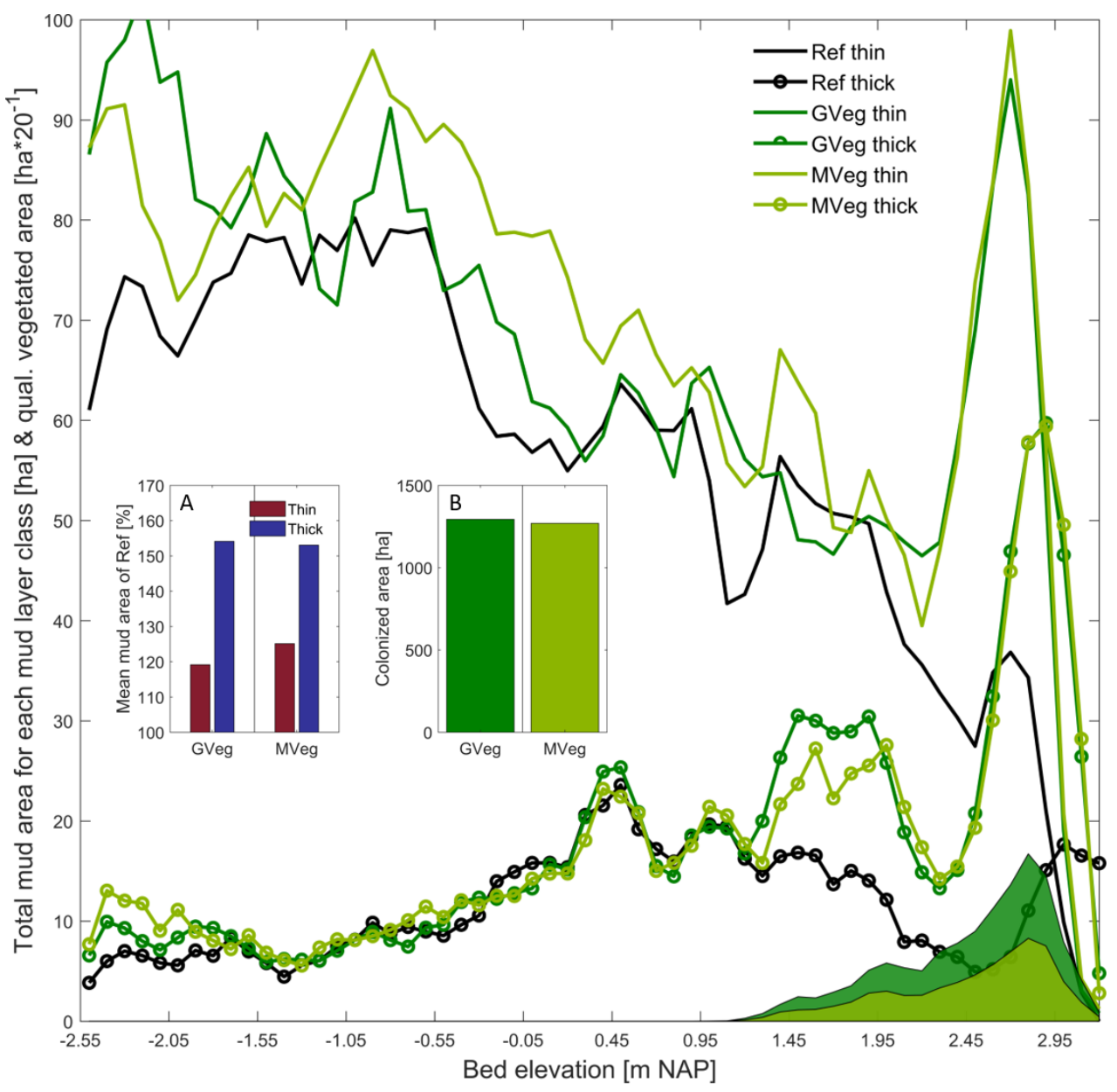

Figure 3.9: Total mud area along bed elevation (0.1m-steps) of thin and thick mud layers of the intertidal area (lines) shows largest thin mud area at lowest elevations that reduce towards the higher intertidal while thick mud layers peak at intermediate and high elevations in the reference run. When vegetation is present, the total mud area for both thick and thin layers increases towards the higher intertidal. GVeg increase thick mud layer extent at the marsh edge while MVeg enhances thin layers along the entire bed elevation gradient. The values are smoothed by a moving-average of 5 points. The qualitative mean vegetated area (surface area) shows largest vegetation cover found at highest elevations. The bar plots show enhanced mean mud area compared to a reference run (A) and total vegetated area (B) confirming that GVeg has a larger extent than MVeg. 
erature at the lower mudflats of the tidal bar (Widdows and Brinsley, 2002; Van der Wal et al., 2008; Daggers et al., 2018). Our model predicted enhanced mud layers on the tidal shoal of Walsoorden in the presence of vegetation and MPB despite their seasonality (Figure 3.7). By comparing a generic saltmarsh growing independently of mud thickness with a mud-dependent species expanding gradually with increasing mud cover, our results suggest that antecedent presence of mud can control saltmarsh cover. As a result, on a bar-scale local hydro-morphodynamic conditions control if mud settling precedes vegetation establishment of vice versa. Large-scale morphology is altered by the presence of biostabilizers through their capability to facilitate mud layer formation and thus limiting mud availability on adjacent mudflats and in marshes.

\section{Interactions between biotic and abiotic stabilization}

Saltmarsh growth and expansion depend on several environmental factors, including hydrodynamic stresses and sediment type. Our results show that bed level accretion is not necessarily the main mechanism facilitating plant survival of the generic saltmarsh type even though sediment supply is known to be one important factor for saltmarsh resilience (FitzGerald and Hughes, 2019). Our generic saltmarsh species covers a similar area on the bar from the beginning of the simulation and barely expands with increasing bed elevation (Figure 3.4c). This is especially pronounced compared to the scenario with sand only, where very low sedimentation on the shallow parts of the bar leads to a similar extent in generic saltmarsh species pattern (Figure 3.4b). Instead, flow reduction through plant growth appears to be controlling marsh extent of the generic saltmarsh species, similarly as in Brückner et al. (2019). Mud layers, however, form at different parts of the shoal and drastically increase in extent post vegetation establishment (Figure 3.5c, d). As a result, the accretion of the mud observed in the ecotope maps requires prior saltmarsh growth for large parts of the bar suggesting that preservation of mud on the shoal of Walsoorden is strongly driven by the presence of vegetation. We think that this mechanism can be characteristic for dynamic morphological features, such as tidal bars that experience high flow velocities that prevent large mud fractions on bare flats: While mud can accrete on sheltered, unvegetated parts on the bar, vegetation helps accrete mud in otherwise too dynamic locations (Figure 3.5 and 3.7). This process is based on higher resilience of saltmarshes to hydrodynamics than inherent to mud, which leads to an alteration of the hydrodynamic forcing as soon as vegetation is present and facilitates mud layer formation. As a result, limited saltmarsh growth by hydrodynamic stresses at exposed sites is potentially limiting mudflat formation and expansion.

We find varying behaviour of vegetation species that require different sedimentary conditions for their establishment. The generic saltmarsh, governed by hydrodynamic stresses only, can colonize large parts of the bar while a mud-dependent species gradually increases with enhanced mud settling as mud is not present in the initial bathymetry (Figure 3.4). While the former alters hydrodynamics and sedimentation instantaneously and causes strong mud accretion along the vegetated surface, the latter facilitates gradual increase in surface mud content by concurrent saltmarsh expansion. On a decadal time-scale, the mud-dependent species is not capable of covering the same extent as the generic species, but nevertheless shows closer resemblance to observed saltmarsh development. This suggests, that mud de- 
pendent saltmarsh establishment might be an important factor constraining saltmarsh development observed in nature.

Van Hulzen et al. (2007) showed that Spartina prefers muddy sediment due to enhanced nutrient availability and soil drainage. Moreover, seed retention in the bed was linked to both a lack of mud erosion (Zhu et al., 2014) or mud deposition (Xiao et al., 2009). Consequently, the suggestion from literature that antecedent mud presence can facilitate saltmarsh growth together with our model results, point to the presence of a geomorphological window of opportunity similar to Balke et al. (2014). If saltmarsh formation is strongly governed by mud presence during recruitment in early spring, then the presence or absence of winter storms, removing or conserving the top mud layer, exert a major control on saltmarsh development. Thus, initial saltmarsh colonization might not only depend on the hydrodynamic conditions during seed dispersal but similarly on the preceding hydrodynamics allowing for mud settling prior to seedling germination. The existence of a geomorphologic window of opportunity is thus based on the occurrence of seasonal disturbances such as winter storms, and might help elucidate observed differences in interannual saltmarsh growth in dynamic coastal environments. However, we expect that as soon as saltmarsh establishment takes place vegetation potentially relies less on mud for survival due to its eco-engineering capabilities (Brückner et al., 2019), but still constitutes an important habitat for mud to settle. We show that the feedback-loop between mud sedimentation and species growth leads to different emerging species abundances that are controlled by the preceding geomorphic setting and lead to species-specific mud layer formation.

In contrast to the enhanced settling by the saltmarsh vegetation, MPB leads to similar muddy locations as the reference scenario but stabilizes the deposited mud (Figure 3.5 and 3.7) on the shoal of Walsoorden. Stabilization of fine sediments by MPB has been observed by field studies on intertidal flats in the Western Scheldt (van de Koppel et al., 2001; Herman et al., 2001), the Humber estuary (Widdows and Brinsley, 2002) and the Wadden Sea (Riethmüller et al., 2000). However, on intertidal flats the destruction of the biofilm by grazing through macrofauna and shore birds is an important control on the stability of the mudflat that we do not account for (Herman et al., 2001; Widdows and Brinsley, 2002; Van der Wal et al., 2008; Mathot et al., 2018). Similarly, we simplify erodibility reduction by MPB by assuming a constant biomass that possibly overpredicts local biostabilization. The balance between biostabilization through MPB and grazing by Macoma balthica largely depends on yearly variations in temperature, where warm winters can lead to decreased grazer densities (e.g. M. balthica) and large microphytobenthic cover (Widdows and Brinsley, 2002). In the face of global warming increasing biofilms will affect fine sediment dynamics by local stabilization and accretion. We found that MPB occurs only $20 \%$ of the total simulation time (not shown) but surprisingly can lead to higher mud fractions in the bed layers over several years. Consequently, the seasonal effect of MPB can have a long-term effect on mud retention. Resulting emerging patterns contribute to locally enhanced bed elevation, sediment refinement and increasing stability of the intertidal area that persist throughout several years.

Our results show that mud layer formation is largely governed by local interactions between biotic and abiotic processes. The elevational gradient of stabilization along the mud flat-saltmarsh interface leads to increasing local mud layer thickness and as a result con- 
trols the development of the cross shoal profile. New vegetation establishment on tidal bars enhances sedimentation and acts as a local sediment sink that can facilitate saltmarsh establishment. However, maturity of the marsh leads to organic accretion rates enhancing bed elevations while autocompaction (not modeled here) reduces mud thickness that add further challenges to the predictions of mud sedimentation and bed level changes in estuarine systems (Allen, 2000). However, we do not expect these simplifications to change the main trends observed in our results, where biostabilizers facilitate mudflat formation and expansion and on a secondary level control the extent of marshes and MPB. Vegetation establishment in areas with high flow velocities is crucial to allow for mudflat formation, whereas mud was not a prerequisite for saltmarsh growth, but potentially an important factor limiting their extent.

\section{Conditions for inter-annual mud preservation}

Deposition of fine sediments in intertidal areas is controlled by the hydrodynamics, such as flow velocity and inundation period, as well as sediment supply. Generally, the total trapping within the vegetation is highest for a combination of high water levels and low biomass, leading to largest accretion at the beginning and end of the growth season. Increasing water levels and reduced plant sizes during winter allow for longer inundation times that lead to larger sediment accretion. On the other hand, mud accretion under MPB presence mainly occurs during their growth period stabilizing present mud layers (Figure 3.6). Understanding the conditions under which seasonal mud layers form and get preserved in the stratigraphy is crucial for ecological functioning, the prediction of bar stability as well as marsh resilience in threatened environments through sea level rise or human impact (FitzGerald and Hughes, 2019). To be able to determine which parameters control mud layers under two types of biostabilizers, we analyse the relationship between mud thickness, mean inundation period, 90-percentile maximum flow velocities and bed elevation over the last four years of simulation time on the shoal of Walsoorden (Figure 3.10). We define two mud thicknesses: thin or seasonal and thick or multi-annual mud (Herman et al., 2001). The reference scenario (triangles), the generic vegetation species scenario (circles) and the microphytobenthos scenario (crosses) are linked to bed elevation (color shades), while the regression line represents the averaged ratio between inundation period and velocity.

On the shoal of Walsoorden, the hydrodynamic forcing is reduced through the presence of vegetation, which shields the mud layers from erosion and enhances bed accretion up to several decimetres thickness (Figure 3.6 and 3.10). As a result, seasonal mud that is otherwise removed during winter can be preserved in the stratigraphy as has been reported by other authors (Le Hir et al., 2007). As the top 1-2 cm of the sediment are the biochemically active part of the mudflat that acts as an interface between the benthic and aquatic as well as the atmospheric and anaerobic system (Chen et al., 2016) the understanding of seasonal mud layer formation is crucial to guarantee ecological functioning of estuaries. We found that thin layers (red data points) can establish under dynamic conditions characterized by high velocities and long hydroperiods (Figure 3.10). Contrastingly, thick layers (blue data points) form at low flow velocities and short inundation periods. This indicates that seasonal mud settling can occur under a wide range of hydrodynamic combinations while thick layers 
require calm conditions. The MPB scenario preserves mud at lower bed elevations than the reference run, while vegetation promotes settling at higher elevations on the bar (see also Figure 3.4 and 3.7). The latter induces small flow velocities and slightly shorter inundation periods that are caused by the vegetation roughness. Contrastingly, MPB allows formation of thin layers at locations with higher flow velocities and inundation period than the reference scenario through reduced erodibility of the mud. In contrast to previously reported results (e.g. Le Hir et al., 2007), the formation and stability of thick mud layers is strongly enhanced by biostabilization that controls mud preservation beyond its direct seasonal impact.

The slope of the regression line is an indicator for the ratio of hydroperiod and flow velocity required for mud layer formation (Figure 3.10B). While the reference scenario has a ratio based on the physical and empirical relations in the model, biostabilization-induced effects alter the inundation period-velocity ratio in two ways: MPB has largest effects on the formation of thin layers that are facilitated under higher relative velocities while vegetation strongly reduces velocities with relatively high inundation periods causing the ratio to increase. Ultimately, these mechanisms determine mud thickness along bed elevation (numbers in brackets) with thick layers generally occurring at higher bed elevations. The graph confirms that mean bed elevation for the two mud thickness classes increase under vegetation but surprisingly reduce under the presence of MPB. Thus, biostabilization plays a fundamental role in facilitating mud layer thickness along the elevational gradient that emerges from the alteration of the hydrodynamic drivers.

Understanding the importance of biostabilizers and their interaction with their environment for predictions of mud preservation is crucial for dynamic estuarine systems. Even though both biostabilizers have a similar effect on mud preservation, the causes differ: vegetation promotes accretion by a reduction of the flow velocity while MPB reduces erosion by reducing erodibility of the sediment, which in turn allows mud accretion at higher velocities. While the former promotes mud layers in sheltered parts of the bar, the latter facilitates mud settling mainly on unvegetated mudflats where the flow is more dynamic. These two contrasting processes lead to new emerging biota and mud patterns that in turn control the establishment of the type of biostabilizer. The contrasting preservation of fine sediments affects the stability of bars and shorelines and the ecology on intertidal flats (van de Lageweg et al., 2018; Braat et al., 2017).

\section{Large-scale redistribution of sediments}

Our results confirm that mud distribution in the Western Scheldt as reported by previous authors, mainly settles at sheltered sites and increases towards the flanks of the estuary (Figure 3.8) (Braat et al., 2017; van de Lageweg et al., 2018). Similarly, we predict higher mud percentages $(>50 \%)$ at the higher elevations along the estuary and the tidal bars creating a more cohesive and ecologically diverse habitat (Herman et al., 2001; Meire et al., 2005; Braat et al., 2017). As was shown for the tidal shoal of Walsoorden, mud is captured by the establishing saltmarsh at intertidal elevations that otherwise are too dynamic to preserve mud (Figure 3.5). Interestingly, sparse local vegetation cover enhances the total mud area implying that mud accretion is largely facilitated by the vegetation. Consequently, higher up the marsh sediment transport is limited, which reduces mud percentages towards the flanks of 


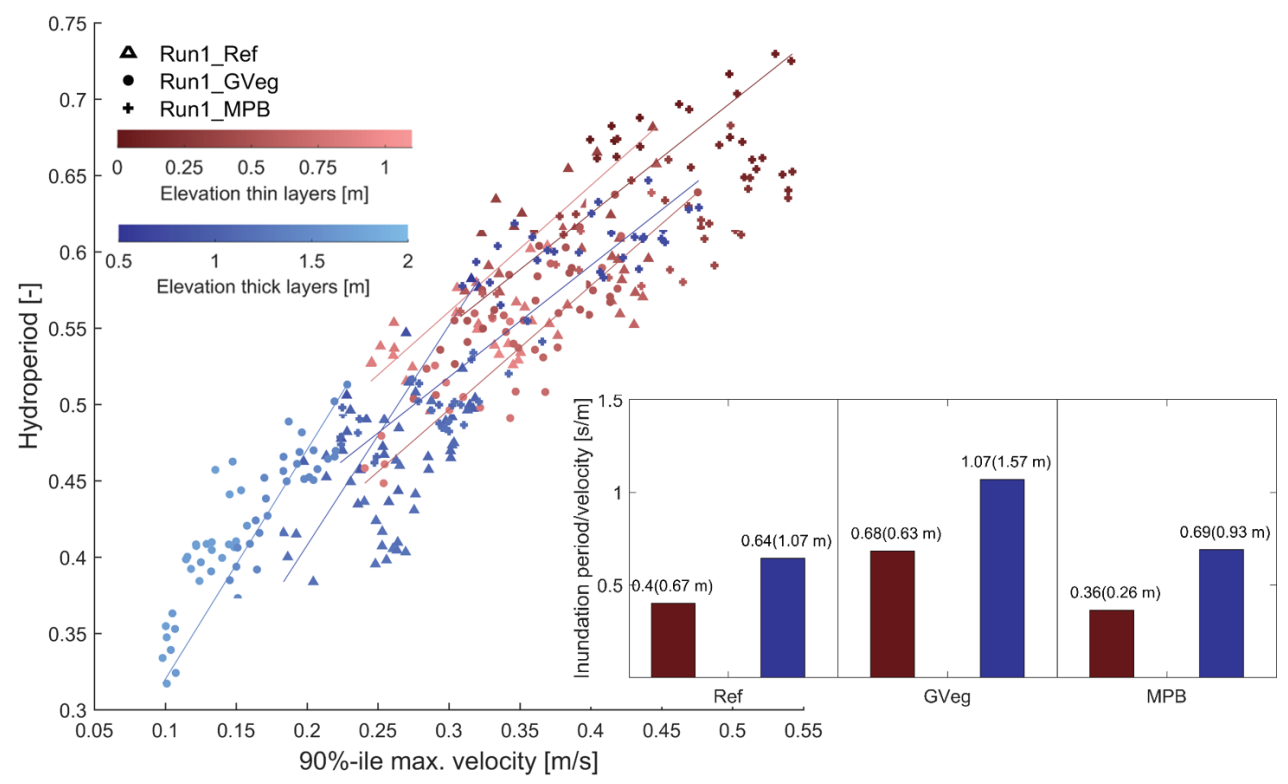

Figure 3.10: Corresponding maximum 90-percentile velocity and hydroperiod of cells containing mud along the last two morphological years of the simulation time on the shoal of Walsoorden. Colors indicate mud layer thickness class (thin: red and thick: blue) and shades bed elevations. Thin layers (red) form at lower bed elevations and similar inundation-velocity ratios for all scenarios, while thick layers (blue) occur higher on the bar and are promoted by contrasting stabilization mechanisms: Vegetation reduces velocity while MPB facilitates mud layer formation at higher velocities and inundation period. Vegetation promotes thick layer formation on the highest elevations of the bar. The bar plot displays the slope of the linear fit in the scatter plot for both thickness classes and all scenarios. Numbers are slope value and corresponding mean elevation in brackets. While vegetation enhances the slopes for both layer classes MPB enhances the slope for thick mud layers and reduces the ratio for thin layers. The mean bed elevation [m NAP] shows that thin layers occur at lower bed elevations than thick layers. Vegetation promotes mud at higher whereas MPB controls mud at lower elevations than the reference.

the estuary compared to the reference run (Figure 3.9). As a result, thick mud layers move from intermediate elevations in the reference scenario towards the higher intertidal under vegetation presence, having wide-ranging effects on the morphological development of estuaries. Similar patterns have been observed in well-established marshes where levee formation leads to reduced transport into the marsh, which can threaten the survival of vegetation at higher elevations (Temmerman et al., 2003). At the same time, thin layers can form under vegetation along the entire intertidal domain. This effect is especially pronounced under a gradually expanding saltmarsh that requires increasing mud in the bed for establishment. Consequently, local marsh species can lead to different mud patterns along the intertidal domain and determine the area covered with mud. As a result, we show that in dynamic estuaries with limited sediment supply large-scale mud pattern and bed accretion are affected by local vegetation.

As a result, changes in fine sediment availability by dredging and dumping activities, construction of dams or storm surge barriers, or nature preservation projects can have wide- 
ranging effects on settling locations and accretion rates. Waves that have been excluded due to tide-domination in the Western Scheldt might lead to enhanced mud transport towards the upstream part of the estuary and reduces mud accumulation on 'Hoge Platen'. Consequently, vegetation cover might be reduced in the more offshore parts of the estuary and lead to larger mud accretion upstream. As a result, the observed redistribution of sediments along the elevational gradient will have large effects on the survival of marsh species that possibly get destroyed under low sediment supply and wave action (FitzGerald and Hughes, 2019). Human induced local changes in sediment availability can therefore have large effects on the survival of marshes and mud layer formation at the larger scale. The amount of vegetation in intertidal areas significantly affects sediment budgets, redistribution of fines, turbidity and siltation, multi-channel formation and ecology.

The large-scale redistribution of sediments differs with inclusion of vegetation that creates sediment scarcity adjacent to and within the marsh. We show that local variations in saltmarsh coverage can lead to a redistribution of fine sediment that holds for similar systems with moderate mud transport rates: The establishment of the vegetation causes sediment scarcity adjacent to the marsh due to enhanced mud settling within the vegetation patch. Consequently, the enhanced local mud settling promotes mud pattern that does not necessarily coincide with the highest bed elevations or vegetation cover (Figure 3.7) but is governed by the hydrodynamics (Figure 3.10). We show that mud layer formation is governed by the interactions between hydro-morphodynamics and dynamic biostabilization that lead to enhanced local mud cover, which persists over decadal time-scales. As a result, the interaction between saltmarsh species, flow and sediment availability controls local mud thickness (Figure 3.4 and 3.8) and marsh expansion, which in turn affects large-scale mud and saltmarsh pattern.

\subsection{Conclusions}

Our novel eco-morphodynamic model shows that saltmarsh growth considerably improves predicted mud deposition. We show that detailed seasonal representations of saltmarsh vegetation, microphytobenthos (MPB) and empirical sediment transport relations determine mud layer location in dynamic estuarine systems. Local mud settling is controlled by saltmarsh species and marsh extent, while generic saltmarsh establishment occurs independently of mud accretion and mud accretion can also occur without prior vegetation establishment. Contrarily, a mud-dependent species shows different expansion and mud accumulation pattern, demonstrating that species type determines mud accretion and that saltmarsh abundance can be controlled by mud.

Seasonal and inter-annual mud layers control saltmarsh establishment and marsh extent as vegetation growth partly depends on a geomorphological window of opportunity that provides sufficient mud cover for plant establishment. Vice versa, mud layers form under different flow conditions mediated by biostabilization. While thin, seasonal layers form under dynamic conditions determined by high flow velocities and hydroperiods, thick, multi-annual mud layers occur in calmer areas. Biostabilizers affect this ratio between hydroperiod and velocity that determines mud layer formation. Vegetation reduces flow velocity more efficiently 
than it enhances hydroperiod, which leads to higher slopes for the mean ratio of hydroperiod and velocity for both thin and thick mud layer. MPB, on the other hand, promotes thin mud layer formation under higher velocities than the reference run. Interestingly, despite the seasonality of the biostabilizers, mud is preserved inter-annually and can lead to longterm changes in morphology. For large-scale morphologies, increasing local mud deposition induced by vegetation leads to reduced large-scale sediment availability: the presence of saltmarsh strongly increases accretion rates at the marsh edge, which leads to sediment scarcity adjacent to the marsh and determines accretion rate in the high marsh. This feedback depends on species type as a generic species promotes thick mud layers at lower elevations in the marsh and a mud-dependent species facilitates new thin mud layer formation in and adjacent to the marsh. Consequently, mediated sedimentation through biostabilization has large-scale implications for sediment availability and hence large-scale morphology.

Our results show that local biostabilization can have large-scale effects on morphology by altering the location and thickness of local mud layers, which results in higher local sedimentation and reduced sediment availability in uncolonized parts of the estuary. For highly managed systems, such as the Western Scheldt, knowledge of sediment budgets and fine sediment accretion is essential for understanding and managing ecological functioning of the estuary. Our findings are applicable to dynamic sandy systems that undergo continuous morphological change through vegetation establishment, benthic activity, changes in sediment availability or human-induced engineering works.

\section{Acknowledgements}

We thank the reviewers for careful reading and contribution to the quality of this work. This research was funded by the ERC Consolidator project 647570 and Utrecht University. The ecotope maps were created by the Dutch Water Authorities (Rijkswaterstaat) and can be found on their website (https://www.rijkswaterstaat.nl). The Nederlands-Vlaams-Model was created and calibrated by Deltares. Delft3D is an open source code available at https://oss.deltares.nl. The dynamic model code is provided under DOI: 10.5281/zenodo.3862032. The authors contributed in the following proportions to conception and design, modeling, analysis and conclusions, and manuscript preparation: $\operatorname{MZMB}(50$, $70,65,70 \%), \operatorname{LB}(5,20,15,5 \%), \operatorname{CS}(15,10,10,15 \%)$, and MGK(30, 0, 10, 10\%) 
$-1$

| | 


\section{Chapter 4}

\section{On the impact of saltmarsh pioneer species-assemblages on the emer- gence of intertidal channel networks}

Tidal marshes play an important role in climate change mitigation through natural coastal protection. The effectiveness of the natural coastal defense by tidal marshes is closely related to their channel network which is in turn greatly influenced by their vegetation cover and shape. Previous research suggests a dual effect of vegetation on marsh topography; stabilizing sediment on the one hand versus promoting erosion and channel incision on the other hand. This study links these effects to different vegetation species, Salicornia procumbens, Spartina anglica, and Puccinellia maritima (further referred to as Salicornia, Spartina, and Puccinellia), by means of a coupled bio-hydromorphodynamic modeling study. Single species, species-assemblages, and species shifts were studied, incorporating both species-specific physical plant properties and spatio-temporal growth strategies. The results indicate the influence of vegetation on the marsh topography to be highly species-dependent, but also of a very complex nature. Both the presence of Spartina and Puccinellia resulted in significant channel development, whereas Salicornia did not induce topographic change. The combination of several species promoted or reduced channel development depending on the included species. Species-shifts linked with climatic changes resulted in increased erosion of the existing channel network potentially reducing the protective capacity of the marsh.

Published as: Bij de Vaate, I., Brückner, M. Z. M., Kleinhans, M. G. and Schwarz, C. (2020). On the Impact of Salt Marsh Pioneer Species-Assemblages on the Emergence of Intertidal Channel Networks. Water Resources Research, 56. https://doi.org/10.1029/2019WR025942 . 


\subsection{Introduction}

Coastal ecosystems are some of the most valued and exploited natural systems around the world (Costanza et al., 1997). Among them, tidal salt marshes are of specific relevance for their role in natural coastal protection (Temmerman et al., 2013). For instance, salt marshes can attenuate storm surges and waves through friction induced by their aboveground biomass. Besides, they provide extra storage area for water and thereby protect the hinterland from flooding in converging estuaries (Leonardi et al., 2018; Temmerman et al., 2013). In respect to global change, tidal salt marshes are capable of following sea level rise due to enhanced sediment deposition during the extended flooding periods thus building natural levees (Kirwan and Megonigal, 2013; Morris et al., 2002). Accordingly, the coastal protection function of tidal marshes is not only crucial for present coastal populations, but also for generations to come (Leonardi et al., 2018).

Tidal marshes consist of vegetated marsh platforms intersected by tidal channels (Allen, 2000). Tidal channels, being the main conduit for the exchange of water, sediment and organisms to the adjacent open water body, provide crucial habitat structure and heterogeneity for tidal marshes. Channels determine aquatic and terrestrial community composition (e.g. Visintainer et al., 2006), hydrodynamics (e.g. Temmerman et al., 2005a) and sediment budgets (e.g. French and Spencer, 1993). Moreover, the effectiveness of the coastal defense function exerted by tidal marshes is closely related to their channel network (Leonardi et al., 2018). For instance, channel dimensions directly relate to landward flood propagation (e.g. Leonardi et al., 2018; Stark et al., 2015), while channel density and extent influence sediment distribution and the ability of the marsh to keep up with sea level rise (Kirwan and Megonigal, 2013; Leonardi et al., 2018; Sanderson et al., 2000). Although the channel network affects the distribution of vegetation in the marsh, vegetation colonization also influences channel formation. Locally, roots have a stabilizing effect on sediment and aboveground biomass increases flow resistance, resulting in increased deposition and stabilization of already existing channel banks, further referred to as short-scale positive feedback (Coco et al., 2013; D'Alpaos et al., 2006). On larger scales (vegetation patch-scale), vegetation has the opposite effect on flow as flow deviation around dense vegetation patches leads to flow acceleration, which results in increased erosion between patches that can lead to channel incision, referred to as large-scale negative feedback (Schwarz et al., 2014; Temmerman et al., 2007). The balance between these mechanisms, also referred to as scale-dependent feedbacks, is closely related to ecosystem properties such as sediment properties, hydrodynamics and plant characteristics (Schwarz et al., 2018; Van Wesenbeeck et al., 2008).

Previously, interactions between vegetation, flow patterns, sediment dynamics and thus tidal channel formation have been attributed to physical plant properties mainly representing a generic Spartina-type salt marsh species. For instance, Temmerman et al. (2007) showed how temporal increase in plant density influenced scale-dependent feedback strength and consequently increased channel density using Spartina anglica as a blueprint. Other studies modeled salt marsh morphology based on Spartina alterniflora as a model species (Best et al., 2018; D’Alpaos et al., 2007; Kirwan and Megonigal, 2013; Morris et al., 2002; Rodríguez et al., 2017). However, physical plant properties and spatio-temporal growth strategies vary 
widely among different salt marsh pioneer species, rendering the general Spartina-type case an oversimplification. Species-specific physical properties, such as stem height, stem density or stem diameter, result in differing magnitudes of patch adjacent velocity acceleration (Bouma et al., 2013). Species-specific spatio-temporal growth strategies result in differences in vegetation cover relative to hydrodynamics stresses over time (Schwarz et al., 2018).

Accordingly, tidal marshes covering a stress gradient from low-intertidal to supra-tidal are rarely occupied by a single species (e.g. Allen, 2000). For instance, the common saltmarsh grass Puccinellia maritima is relatively sensitive to long periods of inundation and therefore restricted to higher marsh elevations while the halophyte Salicornia procumbens is particularly abundant in the lower intertidal zone. Previous studies have shown that this balance between stress-tolerance and competition across the intertidal stress gradient influences sedimentation and erosion patterns (Bockelmann et al., 2002; Erchinger, 1985; Pennings and Callaway, 1992). This leaves the question how this relative complexity of the real situation influences the emergence and shape of intertidal channels in the presence of different species and multi-species assemblages. In addition, due to global climate change topographical shifts in plant distribution are expected (e.g. Kelly and Goulden, 2008; Lenoir et al., 2008). For example, Spartina is likely to benefit from rising temperatures as this enables earlier germination and results in a head start compared to other species (Gray et al., 1991; Gray and Mogg, 2001; Loebl et al., 2006). On the other hand, increased drought will benefit the salt-tolerant succulent Salicornia at the expense of other common salt marsh grasses (Strain et al., 2017). Such topographical species shifts will have a substantial effect on vegetation composition, channel development and provided ecosystem functions of tidal marshes (Gray and Mogg, 2001; Strain et al., 2017).

This study investigates the impact of three dominant marsh species of NW Europe (and combinations thereof) on tidal channel formation: Salicornia procumbens, Spartina anglica and Puccinellia maritima (Bouma et al., 2013). The objective of this study is threefold; (1) investigate the effects of different species-specific vegetation-traits on the initial development of channel drainage patterns, considering species-specific physical plant properties as well as spatial and temporal variation in growth strategies (i.e. life history strategies); (2) elucidate the impact of species assemblages (different combinations of salt marsh species) on channel development; (3) investigate the impact of shifts in dominant salt marsh species on channeland vegetation development.

\subsection{Materials and Methods}

The effect of varying species traits on channel development is investigated by means of coupling between a vegetation model operated in MATLAB and the hydro-morphodynamic model (Delft3D) further referred to as bio-morphodynamic model (Hydraulics, 2006).

\subsubsection{Hydro-morphodynamic model}

Delft3D is a widely used open-source model environment able to calculate flow, sediment transport and morphological change and has been applied and validated in various coastal and estuarine environments. (e.g. Braat et al., 2019a; Fagherazzi et al., 2014; Schwarz et 

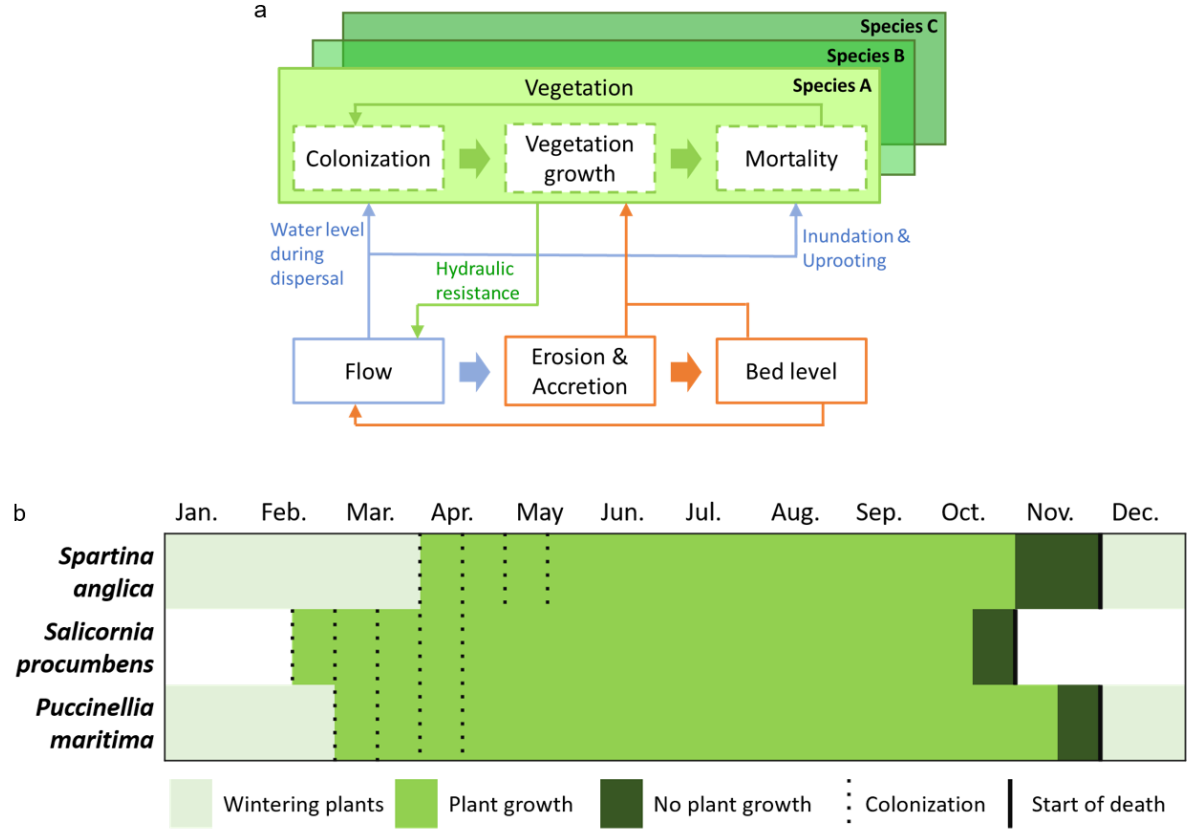

Figure 4.1: (a) Flow diagram of the bio-morphodynamic model, the ecological model is represented in shades of green, the hydro-morphodynamic model (Delft3D) in blue and orange; (b) Temporal variation in growth for Spartina anglica (Alkemade et al., 1994; Gray et al., 1991; Loebl et al., 2006), Salicornia procumbens (Davy et al., 2001; Jefferies et al., 1981) and Puccinellia maritima (Gray and Scott, 1977).

al., 2014). Delft3D simulates flow by solving the conservation of mass and conservation of momentum equations. These equations describe the temporal velocity variations in the $x-y$ plane as a function of advection, friction, eddy diffusivity, water depth and streamline curvature (Lesser et al., 2004). The FLOW-module of Delft3D was used to simulate unsteady flow and sediment transport on a rectangular grid in $2 \mathrm{DH}$ (depth-averaged) driven by a harmonic tidal forcing at the open boundary (Hydraulics, 2006).

For computational efficiency and to ensure tidal propagation independent of lateral boundaries, modeling is performed using two grid resolutions, a small fine grid ( $1400 \times 1050 \mathrm{~m}$, cell size: $5 \mathrm{~m}$ ) nested into a big, coarse grid $(6000 \times 2500 \mathrm{~m}$, cell size: $50 \mathrm{~m})$, which were linked using domain decomposition (Figure C.2). Vegetation growth was only simulated on the fine grid, of which the center part $(600 \times 1000 \mathrm{~m})$ is used for analyses due to lateral boundary effects (Figure C.2). The morphological settings of the idealized model domain represent tidal flat systems typical for NW Europe (Roberts et al., 2000; Schwarz et al., 2014; Temmerman et al., 2007). In the cross-shore direction, the tidal flat slope decreases linearly towards the open boundary with $0.0012 \mathrm{~mm}^{-1}$. The open boundary on the seaward side of the coarse domain is forced by a harmonic M2-tide (period: 744 minutes, amplitude: 1.75 $\mathrm{m}$ ), whilst the other three boundaries are closed. We define hydraulic boundary conditions of 372 days, corresponding to 744 M2-tides, as 1 year. This is multiplied at every computational 
time-step (0.2 minutes) with a morphological acceleration factor (MorFac) of 30, resulting in morphodynamic time-steps of 6 minutes and an overall simulation period of 30 years. Each of these morphological years therefore consists thus of $24 \mathrm{M} 2$-tides. The MorFac was chosen based on the recommended range for morphodynamic upscaling given our choices for grid cell dimensions (Ranasinghe et al., 2011) and considers the criterion suggested by Roelvink (2006) that the chosen MorFac should not significantly alter the flow field and morphological change. Furthermore, compared to previous studies with similar set-ups (e.g. Best et al., 2018; Schwarz et al., 2018; Temmerman et al., 2007) our MorFac is conservatively small. We tested with smaller factors (not shown) and no significant difference was observed in topographic change ( $p>0.99$ ) between tests with a MorFac of 10, 20 or 30.

Our simulations were initiated on a $5 \mathrm{~m}$ thick layer of flat, evenly distributed non-cohesive sand with a median diameter $\left(D_{50}\right)$ of $0.1 \mathrm{~mm}$ and a specific density of $2650 \mathrm{kgm}^{-3}$. This type of fine sand is commonly found on intertidal bars in northwest Europe prior to vegetation colonization (Schwarz et al., 2016). Sediment transport is simulated using the EngelundHansen equation for total transport (Engelund and Hansen, 1967; Lokhorst et al., 2018):

$$
\text { Totaltransport }=0.05 \alpha q^{5} /\left(\sqrt{g} C^{3} \Delta^{2} D_{50}\right)
$$

whereby the median grain size diameter $\left(D_{50}\right)$ and the calibration coefficient $(\alpha)$ are to be specified beforehand ( $D_{50}=0.1 \mathrm{~mm}$ and $\left.\alpha=1\right)$, while the flow magnitude (q), the Chézy friction coefficient $(C)$ and the relative density $(\Delta)$ are cell-specific and updated continuously. Sediment availability from outside the model domain is restricted by means of an equilibrium sediment concentration at the open boundary. This set-up does not induce channel formation in case of an unvegetated marsh (see Figure C.3), allowing to isolate the effects of the vegetation species.

\subsubsection{Ecological model}

The hydro-morphological modeling was coupled to an adapted version of the ecological model by Van Oorschot et al. (2017) that allows to study the effect of physical plant properties as well as spatial and temporal variability in plant growth on sediment dynamics and morphological development (Brückner et al., 2019). The ecological model is coupled every M2-tide (leading to 15.5 morphological days when applying the MorFac), referred to as one ecological time step (ETS). This means that constant forcing is applied in each ETS, resulting in a stable and representative factor for imposing seasonality in vegetation, as such that 24 ETS represents 1 ecological year, and 2 ETS represent 1 ecological month. At every coupling moment (after each ETS), vegetation is updated based on the results of the hydro- and morphodynamic computation and hydraulic resistance caused by the updated vegetation is altered and applied to the subsequent computations in Delft3D (Figure 4.1a). Simulations were run for 20 morphological years.

The effect of vegetation is incorporated in Delft3D by means of adding an extra drag term representing flow resistance in the momentum equation $\left(-\lambda / 2 u^{2}\right)$ based on the hydraulic resistance (Figure 4.1a; Vegetation growth) calculated by the equation adapted from Baptist et al. (2007): 


$$
\begin{gathered}
\lambda=\left\{\begin{array}{l}
C_{D} n \frac{h_{v}}{h} \frac{C_{b}^{2}}{C^{2}}, \text { if } \mathrm{h} \geq h_{v} \\
C_{D} n, \text { if } \mathrm{h}<h_{v}
\end{array}\right. \\
\mathrm{C}=\left\{\begin{array}{l}
C_{b}+\frac{\sqrt{g}}{\kappa} \ln \left(\frac{h}{h_{v}}\right) \sqrt{1+\frac{C_{D} n h_{v} C_{b}^{2}}{2 g}}, \text { if } \mathrm{h} \geq h_{v} \\
C_{b}, \text { if } \mathrm{h}<h_{v}
\end{array}\right.
\end{gathered}
$$

whereby $C$ is the net roughness, $C_{b}$ the real bed roughness, $C_{D}$ the drag coefficient, $n$ the vegetation density (no. of stems per square meter multiplied by stem diameter), $h_{v}$ the height of the vegetation $(\mathrm{m}), h$ the water depth $(\mathrm{m}), \kappa$ von-Kármán constant $(0.41)$ and $g$ the gravitational force $\left(9.81 \mathrm{~m} / \mathrm{s}^{2}\right)$ (Hydraulics, 2006). This approach is a simplification of the way plants interact with sediment in nature where, for instance, the sediment resuspension threshold is not actively, but indirectly modeled through reduced flow velocities generated by friction of vegetation. In addition, Delft3D allows multiple vegetation types to be assigned to one cell by means of composite vegetation function (Hydraulics, 2006). This function sums the contributions in hydraulic resistance of different species scaled by their relative area cover (0-1), thus different vegetation types occupy different fractions of a cell.

Plant colonization assumes seedlings are distributed by the tide. Thus, colonization in the model only occurs in cells of the intertidal area that have been submerged during the previous tide but are dry during low water (Figure 4.1a; Colonization). The actual number of cells that will be colonized depends on the species-specific probability of random establishment. Based on this value, a selection of possible cells will be colonized by the initial fraction of the respective species. The initial fraction describes the initial size of a tussock (as fraction of a grid cell) and varies among species (Table 4.1). If a cell is already populated by an earlier generation or other species the initial fraction reduces to the maximum available space in the cell up to a fraction of 1 (Van Oorschot et al., 2017). Once vegetation has colonized, spatial variability in growth is modeled through linear dose-response relationships related to physical stresses. The model incorporates mortality due to velocity and inundation (Figure 4.1c and Figure C.4).

Mortality is modeled as a reduction in the vegetated area fraction ( $0-1)$ in a cell in response to an exerted pressure. Plants that die, disappear from the model. This is based on flume experiments (Bouma et al., 2013) where plants toppled over due to high velocities and subsequently exerted no more influence on the flow field. Species-specific sensitivity to different stresses was assigned by means of a threshold value and a slope which determines the doseresponse curve. Moreover, stress tolerance was varied in two life-stages, juveniles and adults. Juveniles such as seedlings are more susceptible to stress than adult plants (Table 4.1). Thus, we incorporate three vegetation species in our model through different physical parameters (Equation 4.3) and separate stress tolerance of juvenile and adult plants (further referred to as spatial variation in growth). Furthermore, the model includes seasonal variation in growth 
(Brückner et al., 2019). Seasonal variation is defined from literature by species-specific colonization and growth periods and reduced plant height during winter (Figure 4.1b)

\subsubsection{Species parameters}

Differences between the three considered species are incorporated in the model through differences in temporal variation in growth (Figure 4.1b), spatial variation in growth and physical plant properties (Table 4.1). To reproduce natural development, changes in plant properties throughout ontogenesis were incorporated by assigning different properties for seedlings (first year) and mature plants (years 2-20). Since Salicornia procumbens is an annual species it has only one life stage (of one year) while Puccinellia maritima and Spartina anglica were assigned a second life stage from year 2 onwards. Variability in spatial distribution of the salt marsh species are related to different degrees of susceptibility to hydrodynamic stresses: high velocities and inundation.

The physical plant properties in Table 4.1 are based on available literature (indicated in table) or if absent expert judgement. Values for the chance of occurrence are partly based on observed occurrences of 5\% of Puccinellia patches (Langlois et al., 2003) and the chance of plant establishment of 0.01 (Temmerman et al., 2007) and approximately 0.04 (Schwarz et al., 2014) used in modeling of Spartina. The chosen values are slightly higher because our study only considers establishment and potential connection of small patches (by adding area fractions), whereas the mentioned studies also incorporate lateral diffusion. Lateral diffusion was omitted in this study focusing on bio-morphodynamic feedbacks in a system dominated by seedling recruitment. We test the validity of our approach to represent scale-dependent feedbacks by determining spatial tussock distribution (random, clustered or regular) over time for the single-species Spartina scenario, by calculating the Ripley's K (Ripley, 1977) (see Appendix C). The difference between Salicornia and the other two species aims to reflect their contrasting methods of reproduction (high vs. low dispersal rates). The drag coefficients are calculated based on relations provided by Nepf (1999).

\subsubsection{Scenarios}

To investigate the impact of species assemblages on salt marsh channel emergence we simulated a variety of scenarios, classified as S1: Single species, S2: Multi species and S3: Species shifts from one species to another (Table 4.2). The S1-scenarios allow to compare the singlespecies effects on topography, channel characteristics and tidal asymmetry. The S2-scenarios comprise of all possible 2-species combinations (Multi3-5) and 2 3-species runs (Multi1-2). The first 3-species run uses species-specific traits (Multi1), whereas at the second 3-species run uses species-specific traits except all species have the same susceptibility to flooding (Inundation threshold and slope), which was set equal to the Spartina case (for details see Table 4.1). This was done to investigate the importance of stress tolerance against inundation compared to other indirect effects that determine species colonization. Finally, two runs were performed whereby a species shift was simulated (S3). The first scenario represents a shift from Puccinellia to Spartina and the second scenario from Spartina to Salicornia. The shifts were modeled by using modeled topography of the first species after 30 years, as initial topography for the second species running for 20 more years. 


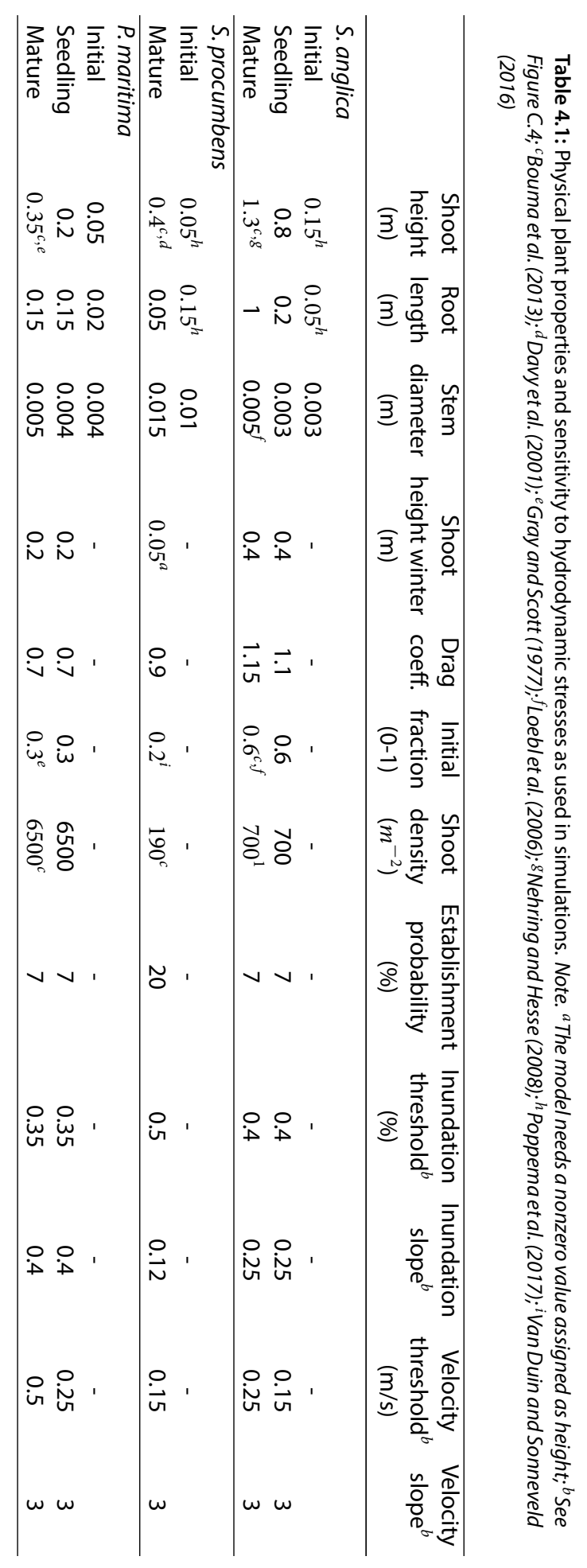


Table 4.2: Classification of modeling scenarios.

\begin{tabular}{lcc}
\hline Scenario & Name & Details \\
\hline S1 & Single species scenarios & \\
\hline \multicolumn{4}{c}{ Spartina } \\
S2 & Pulicornia & \\
\hline \multicolumn{4}{c}{ Multiple species scenarios } & All species \\
Sulti1 & All species, inundation threshold/slope constant (Spartina case) \\
Multi2 & Spartina and Salicornia \\
& Multi3 & Spartina and Puccinellia \\
Multi5 & Salicornia and Puccinellia \\
\hline & Species shift scenarios & \\
\hline
\end{tabular}

\subsubsection{Channel extraction}

Channels were extracted using a simple method relying on the difference between the initial topography and the final topography. This simple approach suffices since in our simulations only the presence of vegetation initiates channel development. Channels were assumed to be present where this difference is significant (standard deviation exceeds 0.02). For this extent of the domain $\left(L_{n}\right)$ channels were extracted based on a negative bed level change $(\Delta \mathrm{Z}<-$ $0.03 \mathrm{~m}$ ) and a sufficient number of neighboring cells (to ignore isolated depressions). Based on the extracted channel networks, drainage density was calculated as the combined length of all channels over the contributing area (Marani et al., 2003):

$$
D D=\text { no.channel cell } * \delta x /\left(L_{n} \Delta Y \delta x \delta y\right)
$$

Whereby $\delta \mathrm{x}$ and $\delta \mathrm{y}$ represent the grid cell dimensions and $\Delta \mathrm{Y}$ (domain width) and $L_{n}$ are given in number of cells. In addition, channel depth was calculated as the first percentile and bank height as the $99^{\text {th }}$ percentile of bed level change.

\subsection{Results}

The results will be analyzed per scenario group (S1-3), while figures show the most relevant scenarios together for direct comparison. For a complete set of figures, the reader is referred to the Supporting Information.

\subsubsection{Single species (S1)}

Our simulations show that the distribution of vegetation across the marsh is highly speciesdependent. After 20 years of simulation, Spartina covers about $30 \%$ of the domain, while Puccinellia covers 12\% and Salicornia only 1\% (Figure 4.2a). Salicornia and Spartina grow close to the seaward boundary of the domain and are relatively evenly distributed over the range of elevations, while Puccinellia is more restricted to the upper part of the domain (Figure $4.2 \mathrm{~d}, \mathrm{e}$ ). A slight seaward shift of the vegetation edge can be observed for both Spartina and Puccinellia (Figure 4.2d; 4.3a, d), which is absent in the case of Salicornia. 

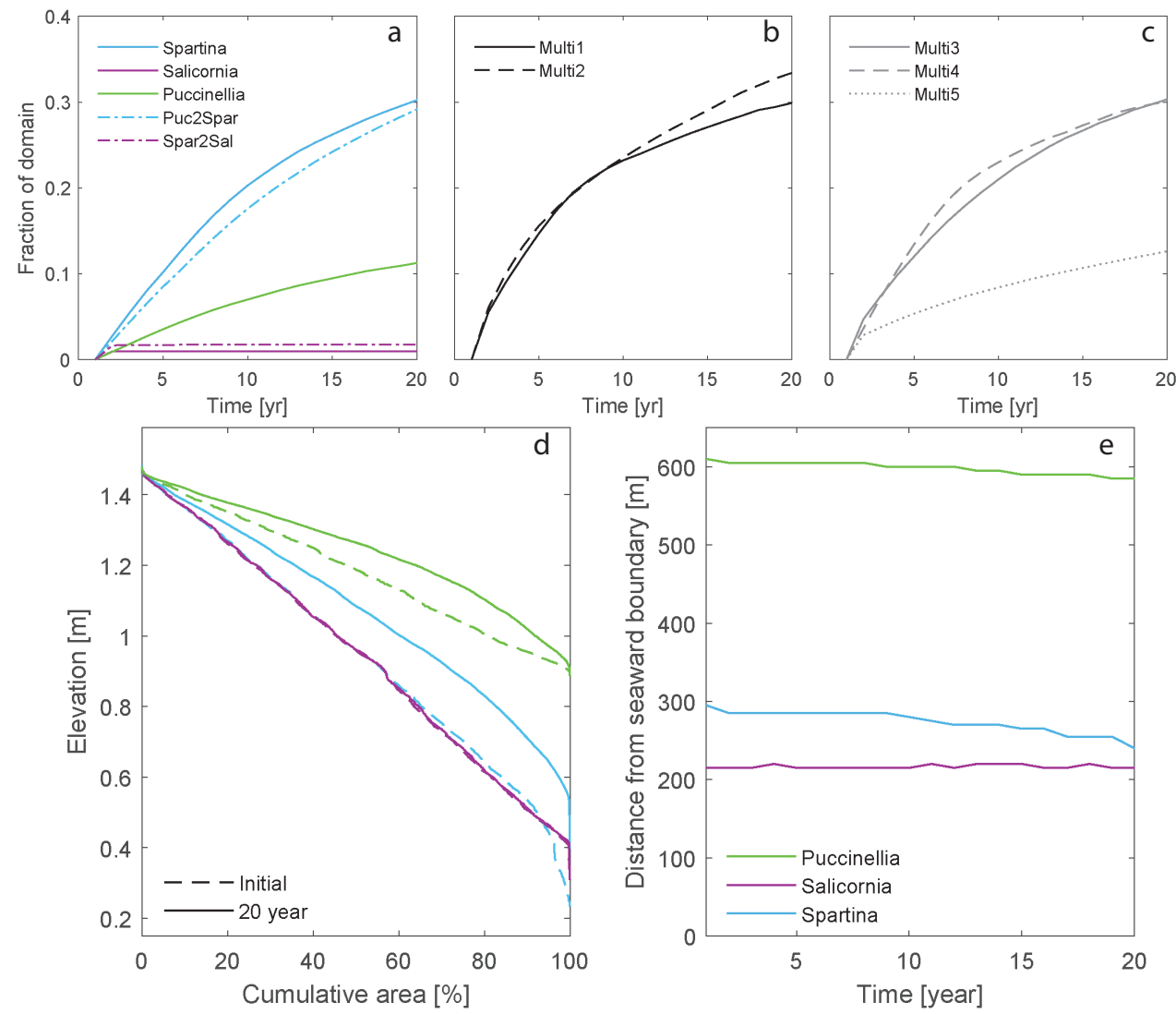

Figure 4.2: (a-c) Temporal evolution of total plant cover as fraction of full domain for a) S1-scenarios and S3scenarios, b) three-species S2-scenarios and c) two-species S2-scenarios; (d-e) Distribution of vegetation in S1scenarios. Temporal evolution of the seaward vegetation edge (d) and hypsometric curves of cumulative bed elevation of colonized cells after 1 year of simulation (e: dashed) and after 20 years (e: solid).

The topography after 20 years (relative to the initial topography) for Salicornia does not display significant changes (Figure 4.3c), while channel development is apparent in the two other vegetation scenarios (Figure 4.3a, d). In the case of Spartina, a very dense and complex channel network has developed landward at $\mathrm{x}=1750$, which coincides with the seaward boundary of the vegetation area (solid line Figure 4.3a). Channels seaward of this point have lower density and complexity and more gradual levees than within the marsh (Figure 4.4a, c, e). The same pattern is visible for Puccinellia (Figure 4.3d), yet the extent and location (channels starting around $\mathrm{x}=2100$ ) of the channel network differs (Figure 4.4b, $\mathrm{d}, \mathrm{f}$ and C.8). In addition, Spartina develops channels with a lower width-to-depth ratio (narrower) than Puccinellia (Figure 4.4 and 4.5a) Comparing total amounts of erosion and accretion per year, the maximum amount of erosion is higher for Spartina $\left(850 \mathrm{~m}^{3}\right)$ than for Puccinellia and Salicornia $\left(400 \mathrm{~m}^{3}\right)$. In the case of the latter two, maximal erosion occurred in year 1 , while for Spartina the amount of erosion increases from year 2 onwards (Figure C.9). Salicornia has 

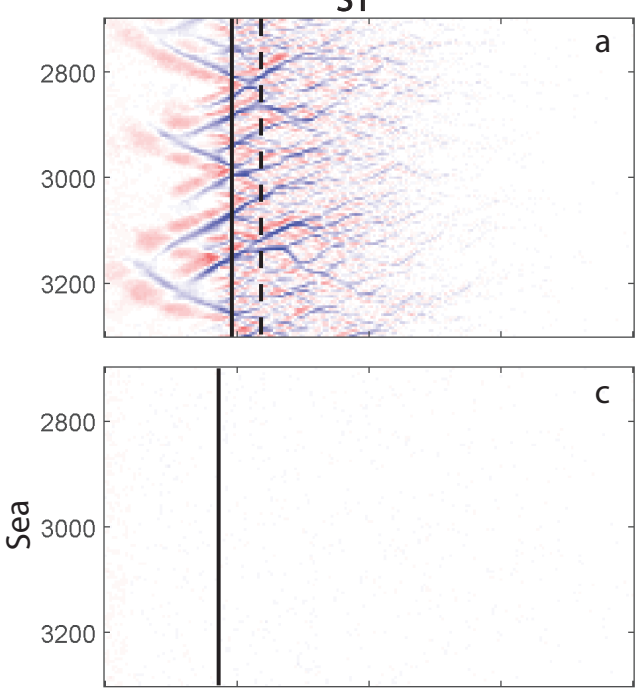

S3

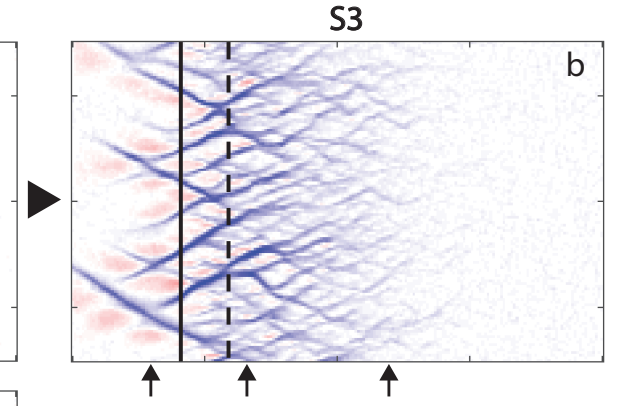

C

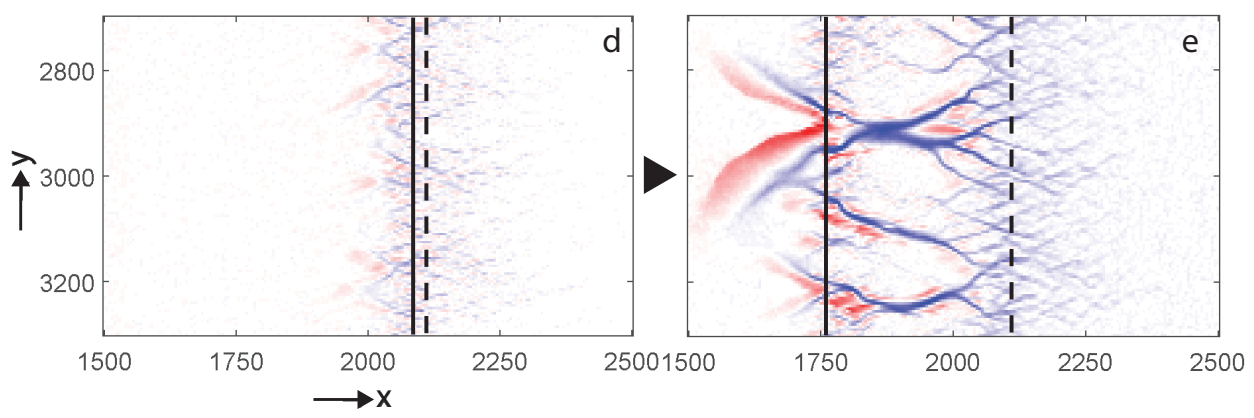

Figure 4.3: Topography after 20 years compared to the initial bed level for the three respective S1-scenarios: Spartina (a), Salicornia (c) and Puccinellia (d) and the S3-scenarios with species shift: Spar2Sal (b) and Puc2Spar (e). Solid lines indicate seaward vegetation edge at the end of simulation and the dashed line the initial vegetation edge showing salt marsh expansion with time for all scenarios except Salicornia only. The arrows in Fig $3 \mathrm{~b}$ indicate location of cross-sections (Figure 4). The topographic change for the S2-scenarios is included in the Supporting Information (Figure C.5) as well as the final topography for all scenarios (Figure C.7).

a relatively constant annual erosion after seven years have passed. Although in all scenarios the net erosion increases over the years, the Salicornia-scenario remains dominated by sediment accretion.

Furthermore, the temporal evolution of the channel network is quantified by the variation in channel depth, levee height, drainage density and network extent (Figure 4.6). All parameters increase over time following vegetation colonization and exhibit a significant difference between Spartina (higher values) and Puccinellia, although the two species initially (until year 2) show similar bed level change (i.e. levee height and channel depth) (Figure 4.6a). The onset of channel formation varies between the two species: year 4 in the case of Spartina and year 7 in the case of Puccinellia. For both species channel depths exceed levee heights. While Spartina and Puccinellia both cause a decline in width-to-depth ratio over time, this 

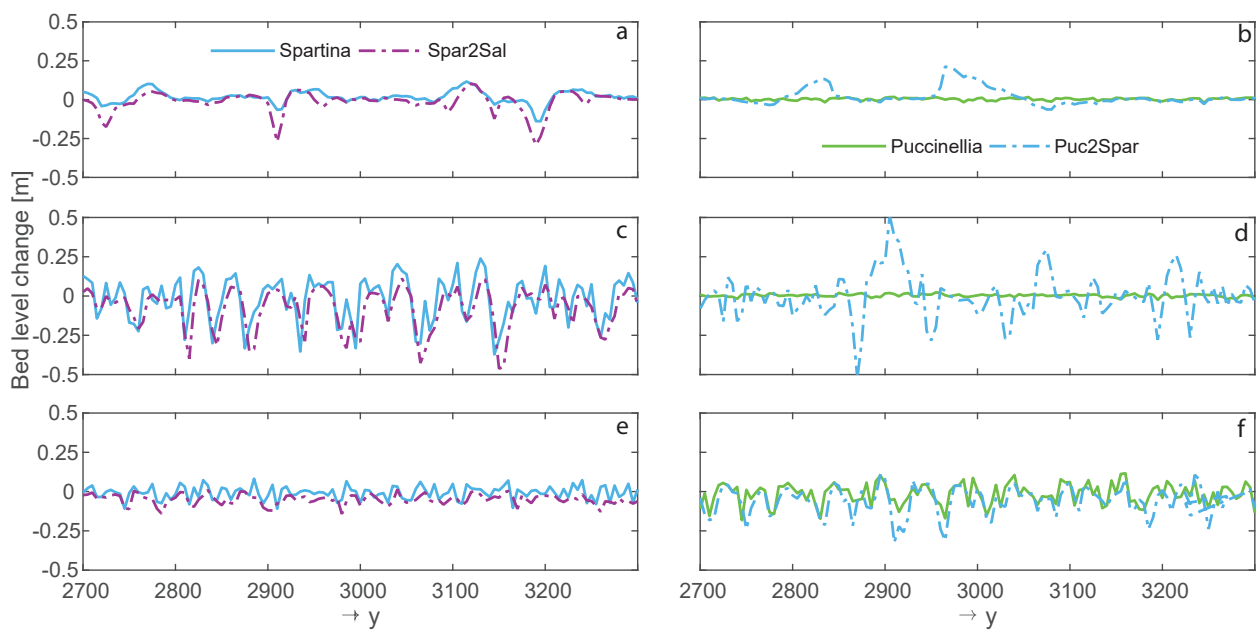

Figure 4.4: Representative cross-sections with bed level variations for S1-scenarios (Spartina and Puccinellia) and related S3-scenarios (Spar2Sal, Puc2Spar) at successive distances from the sea: $150 \mathrm{~m} \mathrm{(a,b),300} \mathrm{m} \mathrm{(c,} \mathrm{d)}$ and $600 \mathrm{~m}(\mathrm{e}, \mathrm{f})$. Salicornia (S1) is not included in the figure because no change in topography was observed. Cross-sections for S2-scenarios are included in Supporting Information (Figure C.6).
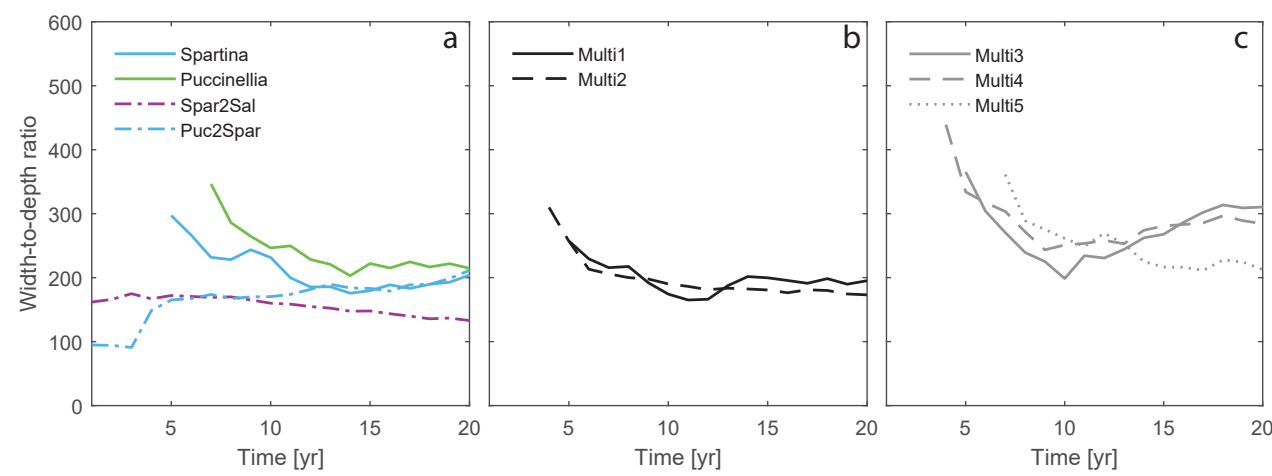

Figure 4.5: Evolution of width-to-depth ratio over time for (a) S1- and S3-scenarios, (b) S2-scenarios with three species and (c) S2-scenarios with two species. Ratios are computed based on average width and depth over the extent of domain where channels are present (variable per year and scenario). 
S1
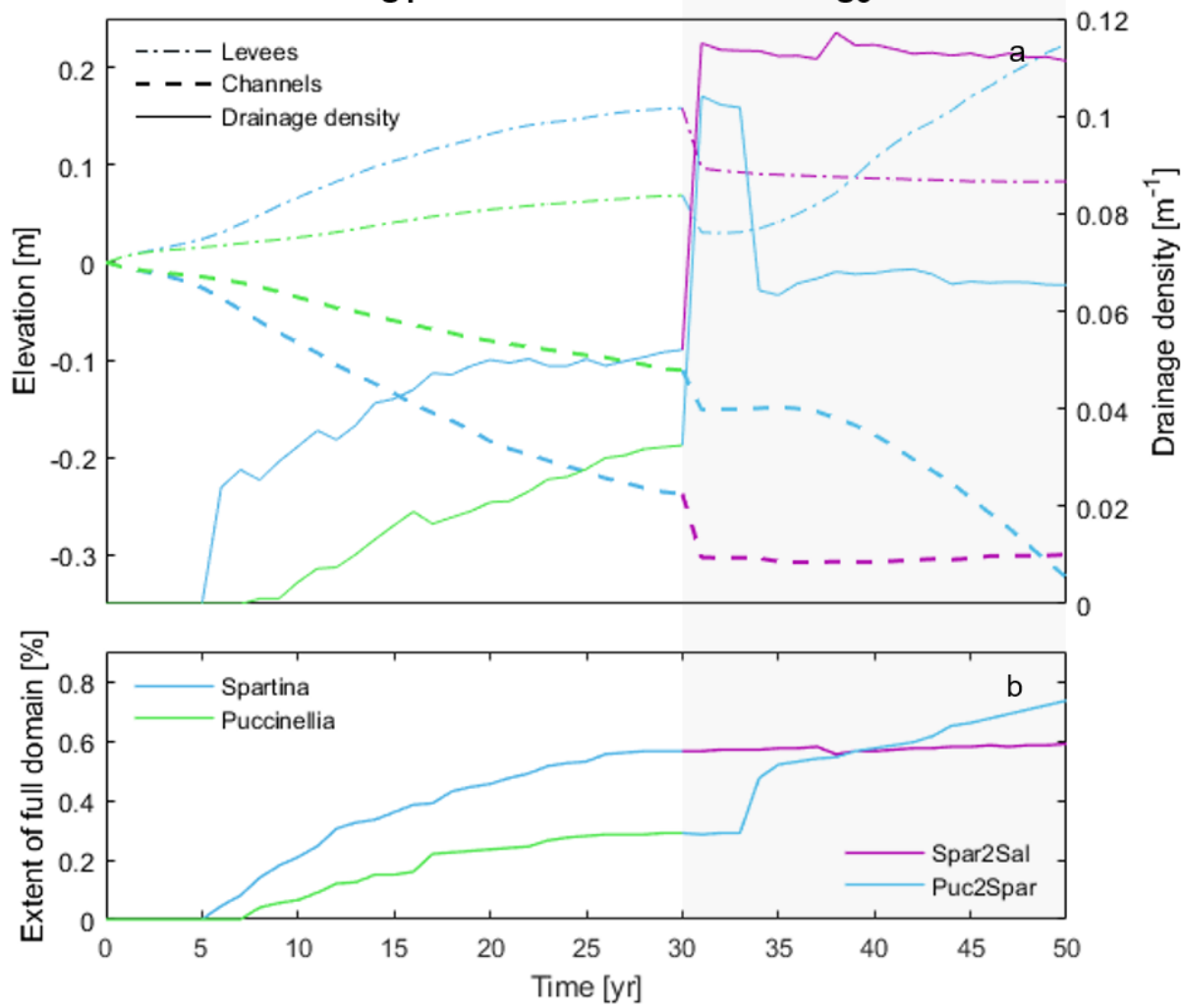

Figure 4.6: Temporal evolution of (a) channel depth (1st percentile of bed level change), levee height (99th percentile of bed level change), drainage density (length of channels divided by surface area) and (b) channel extent (distance between upper and lower boundary of network) for S1- and subsequent S3-scenarios. The S1 Salicornia-scenario is not included since no channels developed.

variable stabilizes earlier and at a higher value for Puccinellia (Figure 4.5a). The presence of vegetation also influences the tidal asymmetry in domain. While the initial situation is flood dominated (Figure 4.7), vegetation colonization and channel emergence with Spartina and Puccinellia makes the system increasingly ebb dominant (Figure 4.7a, c), while colonization by Salicornia makes the system more symmetric (Figure 4.7b). Peak velocities for the Spartina case are slightly larger and are observed at a lower water level $(\mathrm{z} / \mathrm{H}=0.2)$ compared to the Puccinellia case $(\mathrm{z} / \mathrm{H}=0.6)$.

\subsubsection{Species assemblages (S2)}

The general development of plant cover over time of the multi-species runs (Multi1-5) is mainly determined by the presence of Spartina. If Spartina is present plant development reaches a maximum cover about $30 \%$ (Multi1-4), yet if absent the maximum cover drops 

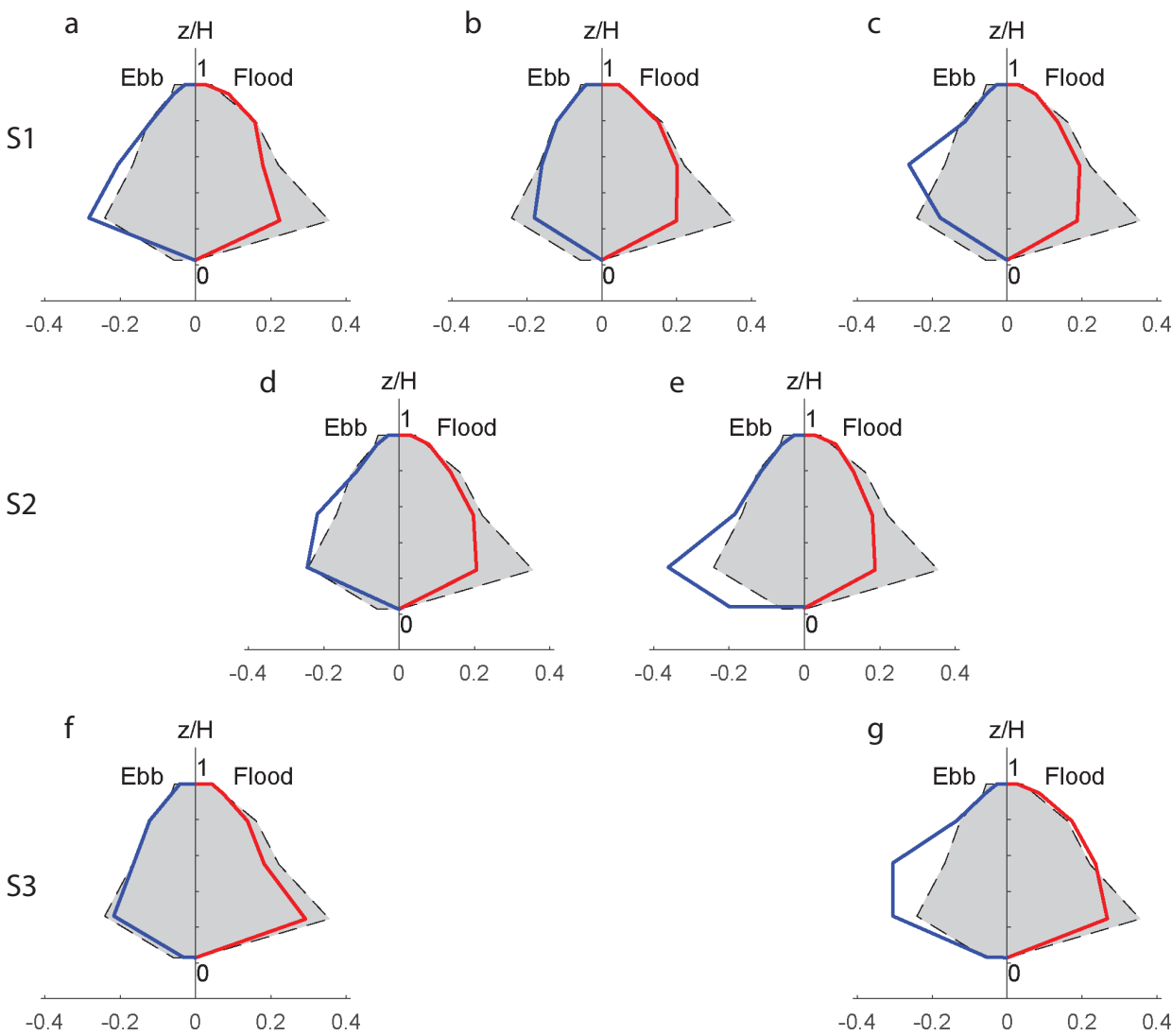

Velocity magnitude $\left[\mathrm{ms}^{-1}\right]$

Figure 4.7: Stage velocity plots for S1-scenarios (a: Spartina, b: Salicornia, c: Puccinellia), two S2-scenarios (d: Multi1, e: Multi2) and the S3-scenarios (f: Spar2Sal, g: Puc2Spar) after 20 years. For the stage (z/H: water level relative to max water level at high water slack, $y$-axis) the average values at the seaward boundary were used. The velocity value (x-axis) is based on the 99th percentile including all cells of the domain. The grey area shows the initial velocity distribution. Note that for the S3-scenarios this is the initial situation at the start of the preceding S1-scenario. Colored lines show changes linked to vegetation presence. If the line is more stretched to either the left (ebb) or the right (flood), ebb or flood becomes dominant over the other. 
to $13 \%$ (Multi5) (Figure 4.2b,c). In the scenarios where both Spartina and Puccinellia are present, the increase in cover during the first 8 years is slightly faster (Multi1,2,4), than at single-species Spartina S1-scenario (Figure 4.2).

The multi-species scenarios (S2) show a zonation in species and biomass in the main flow direction (x-direction) for all scenarios. Since the observed plant distributions between the 2- and 3-species runs are similar, we explain our model findings exemplified on the 3-species run (Multi1). At this scenario we observe an increase in vegetation cover from seaward $(\mathrm{x}=1500)$ to the landward side $(\mathrm{x}=2500)$ (Figure $4.8 \mathrm{~b})$. Focusing on presence/absence, Salicornia is distributed equally over a wide range of elevations, whereas Spartina and especially Puccinellia are restricted to higher elevations, visible by their convex hypsometric curves (solid lines Figure 4.8c). However, when considering the area-fraction per cell occupied by each species, we find a concave hypsometric curve for Salicornia, suggesting the majority of its biomass is located at elevations between $0.2-0.5 \mathrm{~m}$ above mean sea level $(0 \mathrm{~m})$.

The evolution of channel networks for the S2-scenarios is strongly dependent on the combination of species present. Scenarios including Spartina and Puccinellia (Multi1, 2, 4) result in the largest extent of channelized area, whereas the scenario including Puccinellia without Spartina (Multi5) results in the lowest channelized extent among the multiple species runs (Figure C.8b, c and C.5c). The presence of another species alongside Spartina reduces the overall number of channels compared to the single species runs (Multi3, 4) (Figure C.8c and C.5), as well as increases the final width-to-depth ratio (Figure $4.5 \mathrm{c}$ ). The influence of multiple plant species (Multi1,2) on tidal asymmetry shows increased ebb-dominance comparable to the Spartina and Puccinellia single-species runs (Figure 4.7).

We tested the sensitivity of plant zonation, channel development and tidal asymmetry in respect to different groups of model parameters. We tested the importance of spatial growth strategies (governed through inundation stress) by simulating a scenario where species only differ in their physical properties and temporal growth strategies (Multi2) compared to Multi1 where all properties were species dependent (Table 4.1). A comparison between these two scenarios reveals that the total plant cover in the Multi2-scenario is about 5\% higher than in the Multil-scenario (Figure 4.2b). The plant distribution across the intertidal gradient is comparable between Spartina and Puccinellia at Multi2, whereas Multil shows a clear zonation between these 2 species, (Puccinellia/Spartina at high/low elevations respectively) (Figure 4.8). However, the dominance of Salicornia at low elevations remains in both cases (Figure $4.8 \mathrm{c}, \mathrm{d}$ ). Regarding channel development both scenarios show pronounced development of channel networks (Figure C.8b). In the Multil-scenario, channels are more gradual/shallower with a higher width-to-depth ratio (Figure $4.5 \mathrm{~b}$ ). This is particularly visible at the mudflat-saltmarsh boundary (Figure C.5 and C.6a). Regarding tidal asymmetry, Multi2 exhibits higher velocities closer to low water during ebb tide compared to Multil (Figure 4.7d, e).

\subsubsection{Species shifts (S3)}

The pattern in salt marsh colonization after the species shifts is very similar to the $\mathrm{S} 1$-scenarios of the same species. The shift from Puccinellia to Spartina (Puc2Spar) resulted in a slightly lower vegetation cover than the S1 Spartina-scenario, while the shift from Spartina to Salicor- 

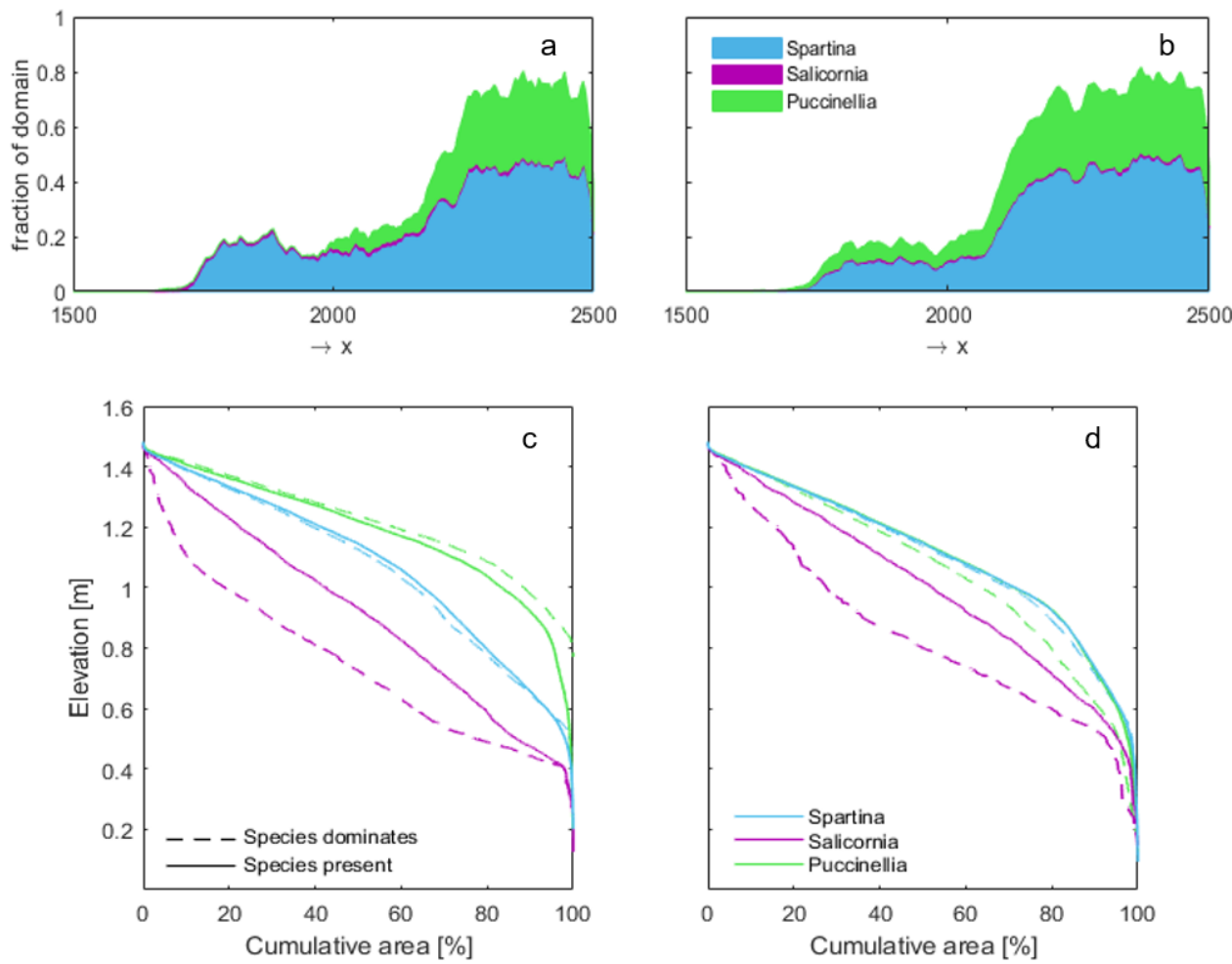

Figure 4.8: Distribution of three species across domain in S2-scenarios Multi1 (a) and Multi2 (b). Accompanied by hypsometric curves for the three species based on the elevations of cells where the species occurs: Multi1 (c) and Multi2 (d). Solid lines are based on all cells were a species is present; dashed curves are based on only cells where the species dominates (species with highest fraction prevails). Note: In (d), the solid blue line (Spartina) overlaps with the solid green line (Puccinellia). $X=1500$ indicates the seaward boundary.

nia (Spar2Sal) resulted in a higher total cover than in the S1 Salicornia-scenario (Figure 4.2a). Both species shifts resulted in a vast increase in erosion. In the case of Puc2Spar increased erosion manifested through a seaward extension of the channel network (Figure $4.3 \mathrm{e}$ and $4 \mathrm{~d}$ ). After 20 years of colonization by Spartina channels created by Puccinellia still remained and got connected to the new marsh edge. This happened through three relatively wide and linear parallel channels (Figure 4.3e), which caused a rapid increase in average width-to-depth ratio across the domain (Figure 4.5a). Additionally, new channels formed at the vegetation edge of Spartina (Figure 4.3e and 4d).

In contrast, the Spar2Sal shift did not result in a significant change in channel shape or extent, but in further erosion of the entire domain (Figure 4.3b). This increase in erosion becomes especially clear when comparing cross-sections from before and after the shift (Figure $4.4 \mathrm{a}, \mathrm{c}, \mathrm{e})$. The Spar2Sal-scenario has resulted in deeper and wider channels as well as erosion of levees. This had little effect on channel geometry as the width-to-depth ratio only slightly reduced (Figure 4.5a). 
Both species shift scenarios result in a rapid increase in drainage density, channel depth and a reduction of levee height just after the shift (Figure 4.6, C.3). In the case of Spar2Sal, the variables remain at this level for the rest of the 20 years. In the case of Puc2Spar, the levee height and channel depth increase from about 8 years after the shift onwards. The drainage density reduces significantly in the third year after the shift, although it is still more than before the shift. 5 years after the shift, the drainage density slightly increases for the following years. In addition, the species shifts alter the tidal asymmetry. The stage-velocity curves in Figure 4.7g show an increase in flood-dominance in the Puc2Spar-scenario compared to the single-species Spartina and Puccinelia cases (Figure 4.8a and c). On the other hand, the Spar2Sal-scenario results in a transition from an ebb-dominant tide at the end of Spartinadominance (Figure 4.7a) to a symmetric situation (Figure 4.7f) that is more similar to the initial conditions.

\subsection{Discussion}

Our results show that channel formation and sediment redistribution of developing tidal salt marshes can be strongly influenced by the colonizing plant species. Moreover, a comparison between different species traits reveals that aside of physical plant properties (e.g. stem height, -density), spatial growth (related to resilience against inundation or currents) and temporal growth properties (i.e. phenology) have important implications on geomorphology. This is showcased by the different degrees of channel development observed between Spartina, Puccinellia, Salicornia and combinations thereof.

\subsubsection{Single species (S1)}

The single species scenarios showed that colonization by perennial grasses (Spartina and Puccinellia) at first did not affect the flood-dominant sediment importing system (Figure 4.7 and C.9). However, in time as colonization by different vegetation species progressed and channels emerged, a shift towards a more (Spartina) or less (Puccinellia) ebb dominated system was observed characterized by sediment export (Spartina, Puccinellia) (Figure 4.7 and C.9). This was also documented in the morphologic development, exhibiting a faster increase in channel depth compared to levee height over time (Figure 4.6). To untangle the influence of growth behavior and physical species traits on marsh topography a set of additional simulations were done, where all parameters were set to a reference value except for the traits of interest. In agreement with Bouma et al. (2013), our tests indicate that the small above- and below ground appearance of Salicornia results in a negligible effect on topography. However, contrary to (Bouma et al., 2013), who focuses on the flow field our analysis showed no significant difference in morphological development between Spartina and Puccinellia based on physical plant properties alone. This could be linked to the resulting emerged-submerged ratio based on a M2-tide in our study compared to only 2 tested water levels in the flume experiment of (Bouma et al., 2013). Additionally by representing vegetation by the Baptist equation we neglect the reconfiguration of flexible Puccinellia which could be improved by alternative vegetation predictors (e.g. Cheng, 2011; Tinoco et al., 2015). 
The different morphologic development between Spartina and Puccinellia in our simulations was mainly caused by different initial vegetation fractions, representing typical tussock sizes and their stem densities, both agreeing with previous studies (Bouma et al., 2013; Bouma et al., 2009a; Temmerman et al., 2007). In addition, the stress tolerance of the species to inundation has a significant impact on the marsh extent and channel development. Where velocities are higher closer to the sea, the presence of a vegetation patch results in more erosion/sedimentation. This potentially caused the increased ebb-dominance of Spartina (wider) with maximum velocities at low water levels and the reduced ebb-dominance of Puccinellia (narrower) with maximum velocities at higher water levels (Figure 4.7). In addition, the shift from a flood- to an ebb-dominated system co-occurred with the formation of wide mudflat channels which resulted in an increase in width-to-depth ratio in the Spartinascenario (Figure 4.5a).

Tidal asymmetry plays an important role in residual sediment transport and the morphology of a marsh (Moore et al., 2009). Flood dominance is associated with increased sedimentation rates, infilling of the marsh and thus increased coastal protection and ebb dominance is linked to exceeding erosion of the marsh and loss of protective capacity (Fagherazzi and Sun, 2004; Friedrichs and Perry, 2001; Lokhorst et al., 2018). We show that different plant species cause different development of residual sediment transport, more specifically erosion exceeds accretion in both the Spartina and Puccinellia scenarios (Figure C.9), whereas accretion dominates in the flood dominated Salicornia-scenario. However, since our simulations for the sake of simplicity only use one non-cohesive sediment class and restricted inflow of sediment into the domain (assumed equilibrium at the boundary), addition of fines could potentially lead to an importing system as reported in previous systems (e.g. D’Alpaos et al., 2007).

Although this study is based on an idealized domain, the vegetation growth behavior and simulated channel development are characteristic of natural systems, which typically show initial fast increase in channel density during colonization, followed by reduced network extension in the maturing marsh (Figure 4.6; Allen (2000)). This is shown by simulated average rates of channel development (Spartina: $23 \mathrm{~m} / \mathrm{yr}$, Puccinellia: $10 \mathrm{~m} / \mathrm{yr}$ ) which are comparable to field observations in the Venice Lagoon (mean rate of $11 \mathrm{~m} / \mathrm{yr}$; D'Alpaos et al. (2007)). Moreover, Van Wesenbeeck et al. (2008) found a close relation between tussock size and channel depth that generally agrees with our result of the large variation in topographic change related to (initial) fraction. Average drainage densities as calculated in this study are of the same order as previous observations in the field (Figure 4.6). For instance, salt marshes in Venice lagoon, Italy range between $0.02-0.025 \mathrm{~m}^{-1}$ (Marani et al., 2003); Barnstable salt marshes, US have find an average drainage density of $0.01 \mathrm{~m}^{-1}$ (Kearney and Fagherazzi, 2016) and Salicornia-dominated San Francisco Bay salt marshes, US show a drainage density of $0.042 \mathrm{~m}^{-1}$ (Sanderson et al., 2000). While the simulated width-depth ratios are high (shallow channels) compared to observations in established marshes $(<10$, Venice Lagoon; Marani et al. (2002)), they are more comparable to values based on tidal flats channels in the Dutch Wadden Sea (100-200; Marciano et al. (2005)).

Regarding species effects, comparison between a Spartina (Walsoorden, Western Scheldt (NL)) and Salicornia marsh (Hooge Platen, Western Scheldt (NL)) shows that the latter 
species has a weaker influence on channel formation with less deep and less pronounced channels (Schwarz et al., 2018). Likewise, Marker (1967) already observed a significant difference in topographic change in the Dee estuary between patches of Spartina (more), Puccinellia (less) and sparsely distributed Salicornia (neglectable). However, we do not only observe comparable network properties, but also changes in the marsh edge. Since salt marsh establishment and channel development altered tidal asymmetry, it also led to redistribution in inundation times across the salt marsh. Since inundation time is one of the factors determining salt marsh's seaward location, we could observe a seaward shift of $200 \mathrm{~m}$ for the Puccinellia and 500m for the Spartina marsh edge over time (Figure 4.3). We expect the amount of change in marsh edge to be strongly linked to channelization of the system which offers important new opportunities to look at salt marsh development in the field.

\subsubsection{Species assemblages (S2)}

The combination of different plant species leads to distinct zones in vegetation distribution. In the Multil-scenario, Puccinellia is restricted to higher elevations, whereas Salicornia dominates the lowest elevations and Spartina the intermediate zone (Figure 4.8a, c). This is in line with common marsh zonation reported in literature (e.g. Beeftink, 1985; Hughes, 2004; Scholten and Rozema, 1990) and the differences in species-specific sensitivity to flooding and uprooting. Although, in our case, Salicornia was often suppressed by other species due to its low initial fraction (0.2), this is not unrealistic. Proffitt et al. (2005) observed similar situations whereby the species was suppressed by Spartina, due to reduced light availability.

The effect of species assemblages on channel development is linked to biomass and location across the tidal elevation gradient of the contributing species. For instance, during our simulations we observed a dominating effect of Spartina on channel development related to its high biomass and ability to grow low in the intertidal. However, it was striking to notice that while some species combinations (i.e. Puccinellia, Spartina, Multi4) increase the number of channels compared to the Spartina S1-scenario, others reduce it (i.e. Spartina, Salicornia Multi3) (Figure C.8) and all two-species combinations resulted in increased width-to-depth ratios (Figure 4.5c). This suggests that competition for space modeled through temporal-and spatial growth properties plays a significant role. Out of the three species, Spartina is the last to colonize, resulting in more restricted colonization due to space limitation. Consequently, cells are already filled with species possessing less hydraulic resistance (i.e. Salicornia) resulting in less channel erosion or more hydraulic resistance (i.e. Puccinellia, especially at high elevations due to less spatial mortality) resulting in more channel erosion (Figure 4.8 and C.5).

A sensitivity test on the importance of spatial growth properties compared to temporal strategies and physical plant properties (Multi1, Multi2) on channel development revealed that equal distribution of all three species over the tidal gradient results in less channels at higher elevations than species-specific zonation (Figure C.8b, 4.8b and C.5b). This underlies the importance of both spatio-temporal and physical plant properties in modeling salt marsh ecosystems. And shows that although ecological interactions (e.g. competition) are not considered in the model, indirect hydromorphodynamic-plant interactions do result in realistic plant assemblages (Multi1). But it also opens new questions in how vegetation zona- 
tion might be able to optimize drainage efficiency of intertidal marshes, which was previously only linked to vegetation presence-absence (Kearney and Fagherazzi, 2016).

\subsubsection{Species shifts (S3)}

We investigate the effect of species-shift scenarios probable to occur over climate change on channel development. Marshes are believed to naturally respond to an increase in sea level by means of increased sedimentation (Kirwan and Megonigal, 2013; Morris et al., 2002). However, on the long term, sea level rise is accompanied with transgression, meaning that upper marsh species are replaced by lower marsh or pioneer species that are less susceptible to inundation (Puc2Spar). Moreover, as shown in the Po-delta in Italy, rising temperatures and increased drought benefit Salicornia over Spartina pioneers (Spar2Sal) (Strain et al., 2017). In this study we aimed to isolate effects of such climate-induced species shifts rather than look at more direct climate effects (e.g. sea level rise).

Shifts between colonizing plant species had an important effect on the resulting channel networks and sediment distribution. The shift from Puccinellia to Spartina (Puc2Spar) resulted in rapid extension of the channel network, which developed into wider and deeper parallel channels, because Spartina is less sensitive for inundation and grows much more seaward (Figure 4.4). This type of channels allows increased ebb-dominance and connectivity between the marsh and the adjacent open water body reducing the protection of the hinterland (Figure 4.7) (Leonardi et al., 2018). The shift from Spartina to Salicornia (Spar2Sal) resulted in wider channels and lowered levees (Figure 4.4) in support of the theory that vegetation has a stabilizing effect on channel banks. The Puc2Spar shift results in a reduced width-depth ratio of the channels (D’Alpaos et al., 2006; Schwarz et al., 2014), while the transition from a densely populated marsh to an almost bare mudflat causes channel banks to erode. Consequently, a species shift from a perennial grass to an annual halophyte (or almost bare mudflat) would be disadvantageous for the protective capacity of the marsh. This has also been pointed out by Strain et al. (2017) who state that an increasing dominance of Salicornia (veneta) would eventually result in a marsh with reduced resilience, and a reduced capacity to respond to sea level rise.

Both species-shift scenarios show that initial channel configuration has an important consequence for the final network. This is showcased by the fact the neither the Puc2Spar nor the Spar2Sal are comparable to any of the other single species scenarios (Figure 4.3 and C.8). We implemented the species shifts as an abrupt shift which might be more gradual in nature. The increase in drainage density that companied with the species shift is an artefact of the way drainage density is calculated and should be omitted (Equation 4.4). However, we could show the importance of climate induce species shifts on marsh morphology, which need further field validation in order to predict all their implications on coastal management and protection.

\subsection{Conclusions}

The aim of this study was to investigate the impact of different plant species on salt marsh and channel development by means of a bio-geomorphic model study. We specifically in- 
vestigated the effect of single species (S1), multiple species (S2) and species-shifts (S3). The single species scenarios (S1) indicate the influence of vegetation on the marsh topography to be highly species dependent, which is related to spatio-temporal variations of vegetation fraction and physical plant properties. Spartina and Puccinellia induce significant channel formation, while Salicornia did not induce channel formation. The multi-species scenarios (S2) show that the species in the assemblage influence channel formation depending on their biomass, and that different combinations facilitate or hamper channel development compared to single species scenarios. The species shift-runs (S3) show that channel network characteristics and sediment transport are very different from other runs underlining the importance of climate induced species-shift on morphology. The results reveal that the medium-scale morphological development of tidal flats strongly depends on saltmarsh species and composition. Climate-induced changes in saltmarsh composition will lead to strong effects on the channel network and drainage capacity on the marsh.

\section{Acknowledgements}

For the modeling study use was made of the Delft3D software from Deltares (source code available here: https://oss.deltares.nl/web/delft3d/download). M.Z.M. Brückner and M.G. Kleinhans were funded by the ERC consolidator project 647570 to Kleinhans. 
$-1$

| | 


\section{Chapter 5}

\section{Benthic species as mud patrol - modeled effects of bioturbators and biofilms on large-scale estuarine mud and morphology}

Sediment-stabilizing and -destabilizing organisms, i.e. microphytobenthos (biofilms) and macrozoobenthos (bioturbators), affect the erodibility of muddy sediments, potentially altering largescale estuarine morphology. Using a novel eco-morphodynamic model of an idealized estuary, we investigate eco-engineering effects of microphytobenthos and two macrozoobenthic bioturbators. Local mud erodibility is based on species pattern predicted through hydrodynamics, soil mud content, competition and grazing. Mud resuspension and export is enhanced under bioturbation and prevented under biostabilization through respective exposure and protection of the supra- and intertidal. Bioturbation decreases mud thickness and bed elevations, which increases net mud fluxes. Microphytobenthos reduces erosion, leading to a local mud increase of intertidal sediments. In multi-species scenarios, an effective mud-prone bioturbator strongly alters morphology, exceeding that of a more abundant sand-prone moderate species, showing that morphological change depends on species traits as opposed to abundance. Altering their habitat, the effective mud-prone bioturbator facilitates expansion of the sand-prone moderate bioturbator. Grazing and species competition favor species distributions of dominant bioturbators. Consequently, eco-engineering affects habitat conditions while species interactions determine species dominance. Our results show that eco-engineering species determine the mud content of the estuary, which suggests large effects on the morphology of estuaries with aggravating habitat degradation. Increasing sea level will induce sandier and more dynamic morphologies that will lead to species migration upstream and a species shift in macrozoobenthic organisms.

Sections 5.1-5.4 and part of 5.6 published as: Muriel Z. M. Brückner, Christian Schwarz, Giovanni Coco, Anne W. Baar, Marcio Boechat Albernaz, and Maarten G. Kleinhans (2021), Benthic species as mud patrol - modeled effects of bioturbators and biofilms on large-scale estuarine mud and morphology. Earth Surface Processes and Landforms.

Section 5.5 and part of 5.6 are based on: Muriel Z. M. Brückner, Giovanni Coco, and Maarten G. Kleinhans, Responses of macrozoobenthic species to sea level rise affect estuarine morphology. In prep. 


\subsection{Introduction}

As transition zones between the river and the sea, estuaries provide valuable ecosystems services, such as natural protection of coastlines, fishing and nursery grounds, and constitute an important habitat for a wide range of organisms (Barbier et al., 2011). Estuarine morphology evolves from a combination of riverine, wave and tidal energy that controls erosion and deposition pattern of sand and mud (Dalrymple and Choi, 2007; Van Ledden et al., 2004; Van der Wegen and Roelvink, 2012; Dam et al., 2016). At the same time, a variety of species thriving in muddy sediments modify their habitat by so-called ecosystem engineering (eco-engineering), a mechanism where organisms directly or indirectly change the physical conditions of their habitat (Jones et al., 1994; Crooks, 2002). As a result, eco-engineering activity leads to changes in the stability of intertidal sediments and can at the same time affect biodiversity through increasing habitat heterogeneity and resulting niche development (Crooks, 2002). These eco-engineering effects suggest that the distribution of mud flats and the morphology of the estuary may change due to the in situ modifications of physical sediment properties. The active reworking of suspended sediments may also have large-scale effects on the mud content and the sediment balance of the estuary. These would, in turn, provide feedback on the eco-engineering species. This general hypothesis will be tested in this paper by numerical modeling.

Species abundance depends on both abiotic conditions and biotic interactions. Species occurrence in multi-species environments has been previously related to abiotic factors, such as temperature, sediment properties, hydrodynamic stresses and salinity, allowing for species predictions based on statistical relationships found through field measurements (Herman et al., 2001; Ysebaert et al., 2002; Thrush et al., 2003; Ysebaert et al., 2003; Singer et al., 2016; Cozzoli et al., 2017). In general, Ysebaert et al. (2002) and Fujii (2007) reported a reduction of bioturbator abundance from the mouth towards the upstream parts of the Western Scheldt and Humber estuaries. Similarly, along the inundation gradient abiotic and biotic parameters lead to distinct species zonation (Ysebaert et al., 2002). However, the spatial pattern and density of species is also a function of species interactions, such as competition for space and resources, and predation. Foraging pattern as well as the species' individual life-cycles control reproduction, migration and feeding activity (Wilson and Parker, 1996). Hence, disturbances of the ecosystem that cause habitat alteration or degradation will change the community structure, evoking direct effects on the morphology of the estuary (Heck et al., 2008). We therefore require a more holistic understanding of the interacting biotic and abiotic processes that determine species distribution and abundance, especially in view of increasing pressures by climatic changes and human impacts, species invasion or biodiversity loss.

Mud, a mixture of silt and clay $\left(D_{50}<63 \mu \mathrm{m}\right)$, can have strong effects on the morphology of estuaries through stabilization of shorelines and tidal bars (Mitchener and Torfs, 1996; De Jorge and Van Beusekom, 1995; Braat et al., 2017; van de Lageweg et al., 2018). The presence of mud in the bed shapes the morphology of tidal systems through the counteracting effects of sediment refinement and cohesiveness: with increasing mud content, the bed becomes first more erosive because of sediment fining; however, when the bed comprises large mud 
fractions, the bed becomes cohesive and erodibility is strongly reduced (Van Ledden et al., 2004; Le Hir et al., 2007). As mud settling is largely governed by the hydrodynamics, the largest mud fractions can be found in sheltered intertidal areas leading to higher bed elevations and infilling of small tidal channels (Braat et al., 2017; van de Lageweg et al., 2018; Kleinhans et al., 2018; Brückner et al., 2020). This local stabilization of the estuarine morphology leads to less dynamic channel networks with stable bars and steeper bank slopes that can be colonized by marine organisms and vegetation (Braat et al., 2017).

However, organisms that live within or on top of intertidal mud alter the stability of the mud cover. Microphytobenthos growth enhances seasonal mud stability of intertidal mudflats through secretion of extracellular polymeric substances (EPS). These EPS form biofilms which protect the sediment matrix of the top bed from erosion during spring and summer and can be washed away during storms and floods in autumn (Paterson, 1994; Vos et al., 1988; Yallop et al., 1994; Widdows and Brinsley, 2002; Chen et al., 2017; Daggers et al., 2018; Van der Wal et al., 2008; Le Hir et al., 2007). Their stabilizing effect strongly reduces mud resuspension on intertidal flats and can lead to a local increase in mud layer thickness (Widdows and Brinsley, 2002). As a result, the presence of microphytobenthos alters the resuspension threshold of mud, the erosion by waves and currents and hence the stability of mudflats.

Several studies on intertidal flats reported a shift between stabilization of sediments in spring through encroachment of microphytobenthos and destabilization by grazing macrobenthos during summer and autumn, leading to seasonally altered mud thickness and suspended sediment load on intertidal flats (van de Koppel et al., 2001; Herman et al., 2001; Widdows et al., 2004). Deposit-feeding macrozoobenthic species can reduce the stabilizing cover of the microphytobenthos through grazing (Widdows et al., 2000). In addition, bioturbation induced by the movement of macrozoobenthos can directly destruct the cohesive mud cover through the creation of burrows and tracks (De Deckere et al., 2001; Montserrat et al., 2008). This effect was measured to be greatest on muddy sediments where bioturbation reduces sediment cohesion ( $\mathrm{Li}$ et al., 2017). Consequently, macrozoobenthic bioturbation not only decreases the erosion threshold of the sediment but also increases resuspension rates. Systems dominated by biostabilizing or bioturbating species are therefore affected by contrasting resuspension rates of mud that lead to varying mud coverages and protection of intertidal sediments.

Macrobenthic bioturbation is thought to be proportional to the species-specific metabolic rate, defined by the rate of biological processing of energy and material, that scales with animal biomass (Cozzoli et al., 2017; Cozzoli et al., 2019). Several empirical studies quantify species effects on erodibility, either in flume experiments where the effect of species abundance on resuspension was measured or in field studies where morphological change and macrobenthos presence were correlated (e.g. Widdows et al., 2004; Cozzoli et al., 2019). Especially, the mud fraction in the top layer of the bed was found to be important for species behaviour. On the one hand, fine sediment is rich in nutrients compared to sand that can be grazed by deposit-feeding organisms, whereas cohesion can hamper locomotion of species (Li et al., 2017). Furthermore, pollutants such as heavy metals and microplastics mainly accumulate in muddy sediments and reduce species productivity (Kröncke et al., 2013). As 
a result, the bioturbation efficiency of macrozoobenthic organisms, in terms of volume of sediment that is processed per unit of time, depends on their habitat quality and conditions.

While increasing numbers of fieldwork-based studies and physical experiments confirmed the effects of various biodestabilizing species on sediment erodibility (Le Hir et al., 2007; Cozzoli et al., 2019), only few studies have tried to disentangle local and large-scale morphological effects of bioturbation. Existing numerical studies model eco-engineering effects of key species, such as stabilization by biofilms (e.g. van de Koppel et al., 2001; Le Hir et al., 2007), bioturbation (e.g. Knaapen et al., 2003; van Prooijen et al., 2011), changes in bed roughness (Borsje et al., 2009; Coco et al., 2006) or sediment mixing in the upper layer of the sediment bed (Paarlberg et al., 2005). Many such models are one-dimensional or cover small- to medium-scale areas, simulating the effect of a single species or few key species. In recent numerical modeling studies large-scale effects of marine vegetation led to a stabilization of the estuary shores, which limited lateral erosion of the estuary (Lokhorst et al., 2018; Kleinhans et al., 2018; Brückner et al., 2020). Possibly microphytobenthos induces a similar confinement of the estuary, whereas destabilization by macrobenthic organisms might promote erosion of the estuarine flanks facilitating lateral expansion. We hypothesize that the dominance of one or more species controls mud coverage and morphology, where biostabilizers promote confinement and bioturbators expansion of the estuary.

To understand how large-scale estuarine morphology evolves under the influence of common bioturbators and biostabilizers, we developed an eco-morphodynamic model that couples a species model with a hydro-morphodynamic model in Delft3D. The species model computes species occurrence based on environmental parameters and feeds biomass-dependent effects on mud erodibility into the hydro-morphodynamic computations based on empirical relations from the literature. We investigate microphytobenthos and two generic macrobenthic species: a mud-prone effective bioturbator inspired by Corophium volutator and a sand-prone moderate bioturbator based on Arenicola marina that are both abundant organisms in estuaries in northwestern Europe.

First, we validate the macrobenthic species predictions on a calibrated hydro-morphodynamic model of the Western Scheldt Estuary as a reference system by comparison to field data. Then, the eco-morphodynamic model is applied to an idealized model domain to analyze evolving mud distribution and morphology under bioturbators, biostabilizers, and their combination. To quantify the importance of eco-engineering effects for species abundances, we compare our results to a control run excluding eco-engineering effects. Our results will inform future management and conservation strategies by improving the understanding of feedbacks between biodiversity and morphology.

\subsection{Methodology}

In order to quantify large-scale morphological effects of microphytobenthos and macrobenthos in estuaries, we applied a novel eco-morphodynamic model consisting of a dynamic species model coupled to the hydro-morphodynamic model of Delft3D. The species computations and the hydro-morphodynamic model were coupled each morphological month. 
The species model is literature-based and comprises two parts: a macrobenthos module and a microphytobenthos module. The former determines species abundance with biomassdependent effects on resuspension threshold and rate. The latter computes presence-absence of microphytobenthos based on habitat conditions and increases the resuspension threshold. The model includes species interactions, such as competition between species and grazing of macrobenthos on the microphytobenthos.

Below we first describe the hydro-morphodynamic domain before we outline the equations that determine temporal and spatial benthic growth, species interactions and eco-engineering effects.

\subsubsection{The Western Scheldt domain}

To compare species predictions of the macrobenthic species with field data, we used a calibrated and optimized hydro-morphodynamic model of the lower Western Scheldt estuary (Nevla-model; for more information see Vroom et al. (2015), Schrijvershof and Vroom (2016), and Brückner et al. (2020)). The model was adapted from the generic vegetation simulation in Brückner et al. (2020) (bathymetry of 2008) with enhanced mud deposition on the bars. We computed the species distributions on the initial hydro-morphodynamic domain that provides values for the environmental parameters that define species growth. This onetime simulation was used to validate trends in species predictions before the idealized model domain was applied to test our hypotheses.

\subsubsection{The idealized hydro-morphodynamic domain}

We run the hydro-morphodynamic computations on a depth-averaged (2DH) configuration of Delft3D. Delft3D is a throughout applied and validated software package solving the shallow water equations (Lesser et al., 2004). Sediment transport is computed using the Engelund-Hansen equation for total transport of sand. The total load predictor of EngelundHansen is chosen since it results in the most realistic bar and channel patterns in long-term morphodynamic models (Baar et al., 2019). The transverse bed slope effect was enhanced to increase downslope sediment transport and counteract unrealistic grid size-dependent incision (Baar et al., 2019). The Partheniades-Krone formulation (Partheniades, 1965) computes the sediment flux of mud $E_{m}\left(\mathrm{~kg} \mathrm{~m}^{-2} \mathrm{~s}^{-1}\right)$ as

$$
E_{m}=\operatorname{MS}\left(\tau_{c w}, \tau_{c r, e}\right)
$$

with $M\left(\mathrm{~kg} \mathrm{~m}^{-2} \mathrm{~s}^{-1}\right)$ the erosion rate, $\tau_{c r, e}\left(\mathrm{Nm}^{-2}\right)$ the critical bed shear stress, $\tau_{c w}=$ maximum bed shear stress $\left(\mathrm{N} \mathrm{m}^{-2}\right)$ induced by the hydrodynamics and $S$ erosional step function that is $S=1$ when the bed erodes and $S=0$ for static or sedimentary beds.

Delft3D solves morphology through an advection-diffusion scheme with sand-mud mixture that includes a critical volumetric mud fraction in the bed set to $P_{m, c r}=0.4$. For mud fractions above this threshold, erosion of both mud and sand is predicted by the PartheniadesKrone formula (Van Ledden et al., 2004).

The idealized estuary was inspired by a trumpet-shaped estuary (Dalrymple and Choi, 2007) and the model developed in Braat et al. (2017). Tides and geometry are based on the 


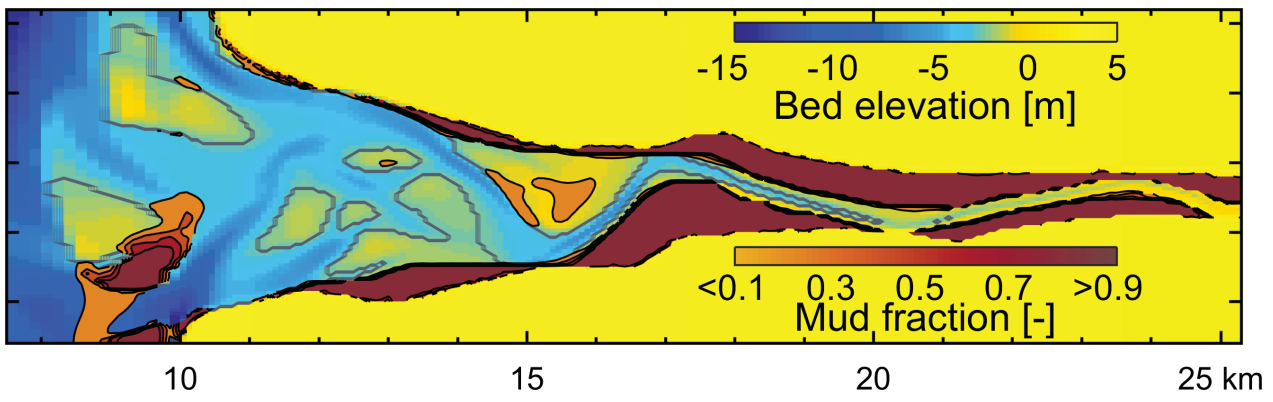

Figure 5.1: Initial bathymetry of the domain with river boundary (right) and tidal boundary (left) in yellow-blue colours. The mud deposits are displayed as contoured mud fractions along the intertidal floodplains and on tidal bars. The grey line denotes the sub-intertidal boundary.

Western Scheldt estuary, a meso- to macrotidal, tide-dominated estuary. The initial estuarine bathymetry evolved from a constant river discharge and M2-tide, equilibrium sand transport and mud supply at the river boundary. Through this set-up, we assume a well-mixed estuary and neglect salinity effects (Olabarrieta et al., 2018). Waves were excluded from the model for reasons of computational cost as well as to mimic the tide-dominated Western Scheldt estuary. The initial condition for the eco-morphodynamic simulations was defined after the development of a realistic bathymetry with sandy bars and muddy shores (Braat et al., 2017; van de Lageweg et al., 2018). First, an initial sandy domain was obtained by computing 2000 years of morphodynamics. After the development of a realistic sandy morphology, riverine mud was included for a simulation time of 280 morphodynamic years, leading to muddy shores and tidal bars (Figure 5.1).

The ecological and morphological time-scales were set equal. To upscale the hydrodynamics to morphological time-scales, a morphological acceleration factor of 60 was applied (Lesser et al., 2004; Ranasinghe et al., 2011). This means that one tidal period represents one morphological month and 12 tidal cycles represent one morphological year. After each tidal cycle, the ecological and the hydro-morphodynamic models were coupled to update the maps of species abundance and mud erodibility used in the hydro-morphodynamic computations. Total simulation time was 50 morphological years, hence, a hydrodynamic simulation time of 600 tidal cycles. The specific model parameters are defined in Table 5.1.

\subsubsection{The macrobenthos computations}

We parameterized two generic intertidal bioturbators that are based on the two macrobenthic species Arenicola marina (AM) and Corophium volutator (CV), both abundant species in estuaries of NW-Europe, such as the Western Scheldt estuary (Ysebaert et al., 2003; Cozzoli et al., 2013). Moreover, the two species differ in their distinct habitat preferences and bioturbation efficiency, specifically sediment properties and inundation gradient (Beukema and Flach, 1995; Ysebaert et al., 2002).

A. marina (lugworms) is a deep-burrowing polychaete that lives in intertidal sediments with low silt content (Beukema and Flach, 1995). Even though they are large in size, their 
bioturbation efficiency is limited by the typically low abundances $\left(<100 \mathrm{ind} . / \mathrm{m}^{2}\right.$ : individuals per unit area). It forms J-shaped burrows with feeding pits and pseudo-faeces that increase sediment exposure to near-bed flow (Volkenborn et al., 2009; Beukema and De Vlas, 1979; Wendelboe et al., 2013). C. volutator (mud shrimp) is an intermediate-burrowing Amphipode that builts U-shaped burrows and actively irrigates the sediment (De Backer et al., 2011). Additionally, C. volutator acts as a deposit-feeder that grazes microphytobenthic diatoms (De Backer et al., 2010). With its preference for high mud content in the bed, its habitat is typically located at the higher intertidal and under low hydrodynamic energy conditions. With high densities up to 20,000 ind. $/ \mathrm{m}^{2}$ its bioturbation efficiency is very high (De Backer et al., 2011). In habitats where both bioturbators occur, A. marina outcompetes $C$. volutator, leading to a distinct boundary between A. marina and C. volutator occurrence (Beukema and Flach, 1995; Herman et al., 2001).

The macrobenthos module, detailed below, comprises two parts: (i) species distribution computations based on environmental parameters and (ii) relations between species abundance and bioturbation effects used for calculating the spatially varying erodibility of the mud. Each coupling, a new abundance of the macrobenthic species is computed for each grid cell based on the output from Delft3D. The resulting eco-engineering effects are fed back into the hydro-morphodynamic model as a modified spatially varying, species- and biomass-dependent critical bed shear stress and erosion parameter of the mud. The updated erodibility of the mud was fed back into the Delft3D model.

Table 5.1: Model parameters as defined in the Delft3D model and the ecological module.

\begin{tabular}{|c|c|c|}
\hline Parameter & value & unit \\
\hline \multicolumn{3}{|l|}{ Numerical settings } \\
\hline Simulation time ecological year & 6 & days \\
\hline Numerical time-step & 0.2 & $\min$ \\
\hline No. ecological time-steps & 12 & per ecological year \\
\hline Grid cell size & 50 by $80-125$ by 230 & [m by $\mathrm{m}]$ \\
\hline \multicolumn{3}{|l|}{ Boundary conditions } \\
\hline Tidal amplitude & 2 & $m$ \\
\hline Principle tidal period & 12 & $h$ \\
\hline River discharge & 100 & $\mathrm{~m}^{3} / \mathrm{s}$ \\
\hline Mud input at river & 100 & $m g / l$ \\
\hline \multicolumn{3}{|l|}{ Sand } \\
\hline Median sand diameter & 0.3 & $m m$ \\
\hline Dry bed density & 1600 & $\mathrm{~kg} / \mathrm{m}^{3}$ \\
\hline \multicolumn{3}{|l|}{ Mud } \\
\hline Settling velocity of mud & $2.5 e^{-4}$ & $m / s$ \\
\hline Crit. bed shear stress for erosion & 0.2 & $N / m^{2}$ \\
\hline Erosion parameter & $1 e^{-4}$ & $\mathrm{~kg} / \mathrm{m}^{2} / \mathrm{s}$ \\
\hline Dry bed density & 1600 & $\mathrm{~kg} / \mathrm{m}^{3}$ \\
\hline \multicolumn{3}{|l|}{ Morphology settings } \\
\hline Transverse bed slope parameter $A_{s h}$ & 0.2 & {$[-]$} \\
\hline Active layer thickness & 5 & $\mathrm{~cm}$ \\
\hline Max. storage layer thickness & 5 & $\mathrm{~cm}$ \\
\hline Morphological acceleration factor & 60 & - \\
\hline
\end{tabular}



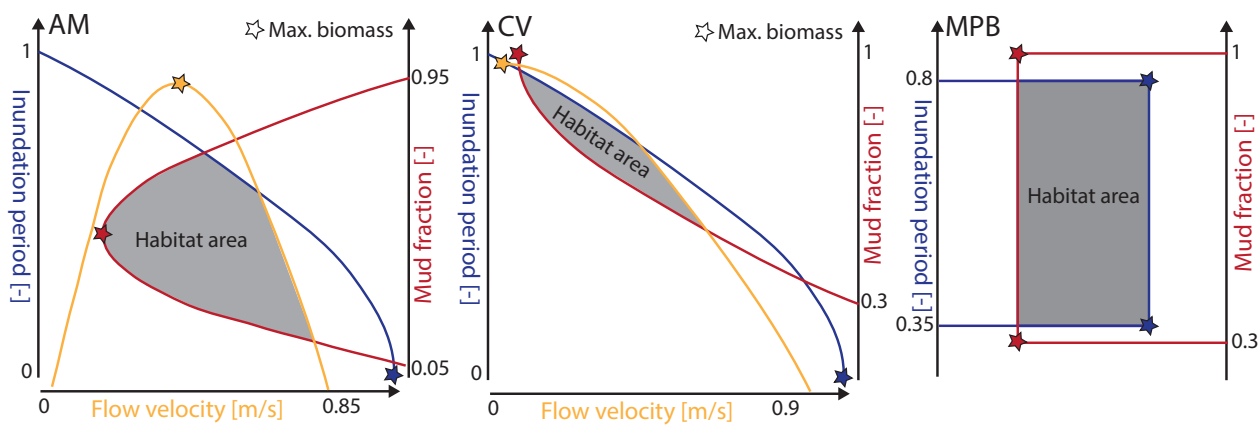

Figure 5.2: The species occurrence as a function of three environmental parameters for the moderate sandprone bioturbator AM (left) and the efficient mud-prone bioturbator CV (middle). The star represents the maximum biomass occurrence for each parameter. The gray area shows the habitat area that the species thrives in. Right: MPB occurrence depends on inundation period and mud fraction in top layer as bimodal distribution (presence-absence).

\section{Species distribution model based on environmental parameters}

To allow for realistic abundances of various macrobenthic species, the model determines species occurrence based the relations reported in Ysebaert et al. (2002) from the Western Scheldt estuary: The relative macrobenthos biomass $B_{\text {rel }}$ is computed based on maximum flow velocity $P_{v}$, mud content $P_{m}$ and inundation period $P_{i}$ as

$$
B_{r e l}=\min \left(P_{v}, P_{m}, P_{i}\right)[-]
$$

which determines habitat suitability based on the limiting environmental parameter (Figure 5.2). As a result, $B_{r e l}$ is the smallest biomass that can survive based on the three environmental parameters and is relative to the maximum biomass that can occur if the conditions were ideal (stars in Figure 5.2).

Even though sediment type, hydrodynamic forcing and salinity are the main determinants of habitat suitability (Cozzoli et al., 2017; Ysebaert et al., 2002; Ysebaert et al., 2003) we neglect salinity as we assume the generic species to dominate along the entire estuarine gradient. Moreover, we focus on intertidal bioturbation, which is a fair assumption as mud settling is limited within the channels of deep estuaries due to high flow velocities and sediment instability (Ysebaert et al., 2003; Heip and Herman, 1995). Seasonality is neglected as we focus on the maximum bioturbation effect of the species persistent throughout the year.

\section{Relations between species abundance and bioturbation effects}

We identified several mechanisms induced by macrobenthos that affect the erodibility of the sediment, such as bioturbation through feeding and reproductive movement, sediment sorting and faecal pellet formation that are expelled at the sediment surface, and grazing of diatoms (Le Hir et al., 2007). These different mechanisms are species-dependent behaviours that can be approximated by an alteration of the erosion rate $M\left(\mathrm{~kg} \mathrm{~m}^{-2} \mathrm{~s}^{-1}\right)$ and the critical bed shear stress $\tau_{c r, e}\left(\mathrm{Nm}^{-2}\right)$ of the sediment (Cozzoli et al., 2019; Wrede et al., 2018). As a result, the sediment flux of cohesive sediment computed by the Partheniades-Krone formu- 
lation (eq. 5.1) is affected by the presence of the organisms. A change in erosion parameter $(M)$ represents the altered erosion flux from the top layer of the bed induced by species motility, sediment sorting or pellet formation. A reduction of the critical bed shear stress $\left(\tau_{c r, e}\right)$ leads to enhanced resuspension by sediment fining, bioturbation or pelletization.

Bioturbation effects depend on species density and size (De Backer et al., 2011). To derive a linear relation between species fraction and increasing erodibility, we used the relations reported in Cozzoli et al. (2019) who measured species-, size- and biomass-dependent resuspension in controlled flume experiments. First, we determined the critical bed shear stress under the influence of bioturbation for a given species at a low resuspension rate of $25 \mathrm{mg}$ $m^{-2} s^{-1}$ and set this as the critical bed shear stress (Widdows et al., 1998a). To derive the erosion rate of the sediment under bioturbation, we then fit a linear function between this value and the maximum resuspension at an intermediate bed shear stress set at $0.5 \mathrm{~Pa}$ in the experiments. The slope of this function is the erosion rate $M$, describing the amount of resuspended sediment per time unit:

$$
M_{b i o, \max }=\left(R_{t o t}-25 \mathrm{mgm}^{-2} \mathrm{~s}^{-1}\right) /\left(0.5 \mathrm{~Pa}-\tau\left(25 \mathrm{mgm}^{-2} \mathrm{~s}^{-1}\right)\right)
$$

This derivation of the erosion rate assumes that the resuspension rate $R_{\text {tot }}$ is constant along the measured time in the experiment. However, empirical values of critical shear stress of the sediments used by Cozzoli et al. (2019) differ from those in the model. To scale the values from the sediment used in the experiments to our model sediments, we computed the factor between the derived values for $\tau_{c r, e}$ and $M$ and those of the uncolonized sediment. The values of the model sediment $\left(0.2 \mathrm{~Pa}\right.$ for $\tau_{\text {crit }, e}$ and 0.0001 for $\left.M\right)$ were multiplied with the factor representing the maximum bioturbation effects at a bioturbator fraction of 1 (for more information see supplementary material Table D.1; final values in Table 5.2). For a macrozoobenthos fraction $f_{b i o}$ below unity, $\tau_{c r, e, b i o}$ and $M_{b i o}$ as used in the model were calculated as

$$
\begin{gathered}
\tau_{c r, e, b i o}=f_{b i o} \times \tau_{c r, e, b i o, \max } \\
M_{b i o}=f_{b i o} \times M_{b i o, \text { max }}
\end{gathered}
$$

\subsubsection{The microphytobenthos computations}

The microphytobenthos (MPB) is modeled as presence-absence and recalculated every coupling interval based on inundation period and mud fraction in the top bed (Figure 5.2). Based on Widdows and Brinsley (2002) we prescribed MPB growth in numerical cells that were inundated between 35-80\% and contained mud fractions above 0.3 (Daggers et al., 2018; van de Koppel et al., 2001), indirectly selecting sheltered areas with limited erosional and depositional processes (Herman et al., 2001).

Linked to the secretion of extra-polymeric substances (EPS), MPB stabilizes the sediment and reduces local erosion (van de Koppel et al., 2001). We account for this effect by an alteration of the critical bed shear stress of the mud fraction. Hereby, we assume that MPB live 
Table 5.2: Physical parameters of the abiotic reference run $R E F$, the two bioturbators $A M$ and $C V$ and microphytobenthos $M P B . \tau_{c r, e}$ and $M$ represent the value for a maximum biomass under ideal environmental conditions. For lower biomasses this value is linearly adjusted between that maximum and the abiotic value (REF).

\begin{tabular}{lcccc}
\hline Parameters & REF & AM & CV & MPB \\
\hline$\tau_{c r, e}\left[\mathrm{~N} / m^{2}\right]$ & 0.2 & 0.11 & 0.02 & 0.35 \\
$M\left[\mathrm{~kg} \mathrm{~m} \mathrm{~m}^{-2} \mathrm{~s}^{-1}\right]$ & 0.0001 & 0.0005 & 0.0004 & 0.0001 \\
\hline
\end{tabular}

on top of the sediments and increase the critical bed shear stress for erosion $\tau_{c r, e}$ by a factor of four during summer (Le Hir et al., 2007) and averaged over one year.

Consequently, the updated abundances emerging from the hydro-morphodynamic computations alter local mud erodibility and allow for a direct response of the morphology to species dynamics. Moreover, our modeling species are based on contrasting species both in terms of their habitat and their eco-engineering effect. All values for critical bed shear stress and erosion parameter can be found in Table 5.2.

\subsubsection{Competition between species and grazing pressure}

We introduced competition between the macrozoobenthic species, by assuming that $A$. marina is dominant over C. volutator following Beukema and Flach (1995) and Herman et al. (2001). This assumption results in the disappearance of CV in model cells that are suitable for both AM and CV. This presence-absence relation is independent of the biomass of each species. Competition is computed at each coupling, meaning that the abundances based on the environmental parameters are instantaneously updated.

Moreover, we considered species-specific interactions between the macrozoobenthic species and MPB. CV grazes on MPB, which leads to a linear reduction in MPB cover depending on the biomass of $\mathrm{CV}$. The new $\tau_{\text {bio,phyto }}$ of MPB is defined as the mean value between $\tau_{b i o, p h y t o, \max }$, which is the value when only MPB is present, and the bioturbator value $\tau_{c r, e, b i o}$ of the present biomass as

$$
\tau_{\text {bio,phyto }}=\operatorname{mean}\left(\tau_{\text {bio,phyto,max }}, \tau_{c r, e, b i o}\right)
$$

Moreover, MPB is dominant over AM, setting the critical bed shear stress to $\tau_{\text {bio,phyto,max }}$. However, we assume that AM bioturbates the lower sediment layers underneath the biofilm and set the erosion parameter of AM.

\subsubsection{Model scenarios}

The eco-morphodynamic model was applied to two different set-ups. First, we simulated the calibrated hydro-morphodynamic model domain of the lower Western Scheldt estuary to compare model predictions with field data. Second, we simulated an idealized domain to investigate and quantify the interactions between eco-engineering effects and estuarine morphology. A variety of scenarios were executed, including reference, single species and multiple species scenarios (Table 5.3). 
Table 5.3: Model scenarios for species in isolation and combination, their eco-engineering effects and species interactions. The dynamic eco-morphodynamic model (E) represents the scenarios with eco-engineering, the control model $(N)$ without eco-engineering effects allows for quantification of the eco-engineering effects for all species and their combination. To investigate the role of species interactions a second control model excludes both ecoengineering effects and species interactions (N2).

\begin{tabular}{llcl}
\hline Model scenario & Species & Eco-engineering effects & Interactions \\
\hline E-REF & - & - & - \\
E-AM & AM & yes & - \\
E-CV & CV & yes & - \\
E-AMCV & AM \& CV & yes & competition \\
E-AMCVMPB & AM, CV \& MPB & yes & competition \& grazing \\
E-MPB & MPB & yes & - \\
\hline N-AM & AM & no & - \\
N-CV & CV & no & - \\
N-AMCV & AM \& CV & no & competition \\
N-AMCVMPB & AM \& CV \& MPB & no & competition \& grazing \\
N-MPB & MPB & no & - \\
\hline N2-AM & AM & no & - \\
N2-CV & CV & no & - \\
N2-AMCV & AM \& CV & no & no \\
N2-AMCVMPB & AM \& CV \& MPB & no & no \& no \\
N2-MPB & MPB & no & - \\
\hline
\end{tabular}

In order to quantify the importance of eco-engineering effects for emerging species abundance, we compare the results from the dynamic eco-morphodynamic model with control runs (N- \& N2-scenarios). The controls consist of models with species distributions calculated as a function of the physical conditions, but without the feedback between ecoengineering effects and the hydro-morphodynamics.

\subsection{Results}

\subsubsection{Validation of species predictions}

To test the predicted species abundances by our model, we first compare the results obtained from the Western Scheldt model domain (bathymetry 2008) with data from Ysebaert et al. (2002) that includes sampling data from 1978-1992 (Figure 5.3). The model predictions represent the trends observed in the data well. As shown from the data, A. marina occurs along tidal bars towards the main channels, whereas $C$. volutator is locally constrained to the bars and flanks of the estuary. The model predicts AM on the small and dynamic tidal bars and lower flanks. CV is restricted to the higher elevations in the centre of bars and along the shores. The considerable data sampling provided extensive information on species occurrence over more than a decade but was limited to the sampling locations, which is why the model predicts comparably larger abundances. However, species predictions deliver satisfying results to characterise general species occurrence of the two generic species. As a next step, we apply the model to the idealized domain to investigate species effects on morphology. 


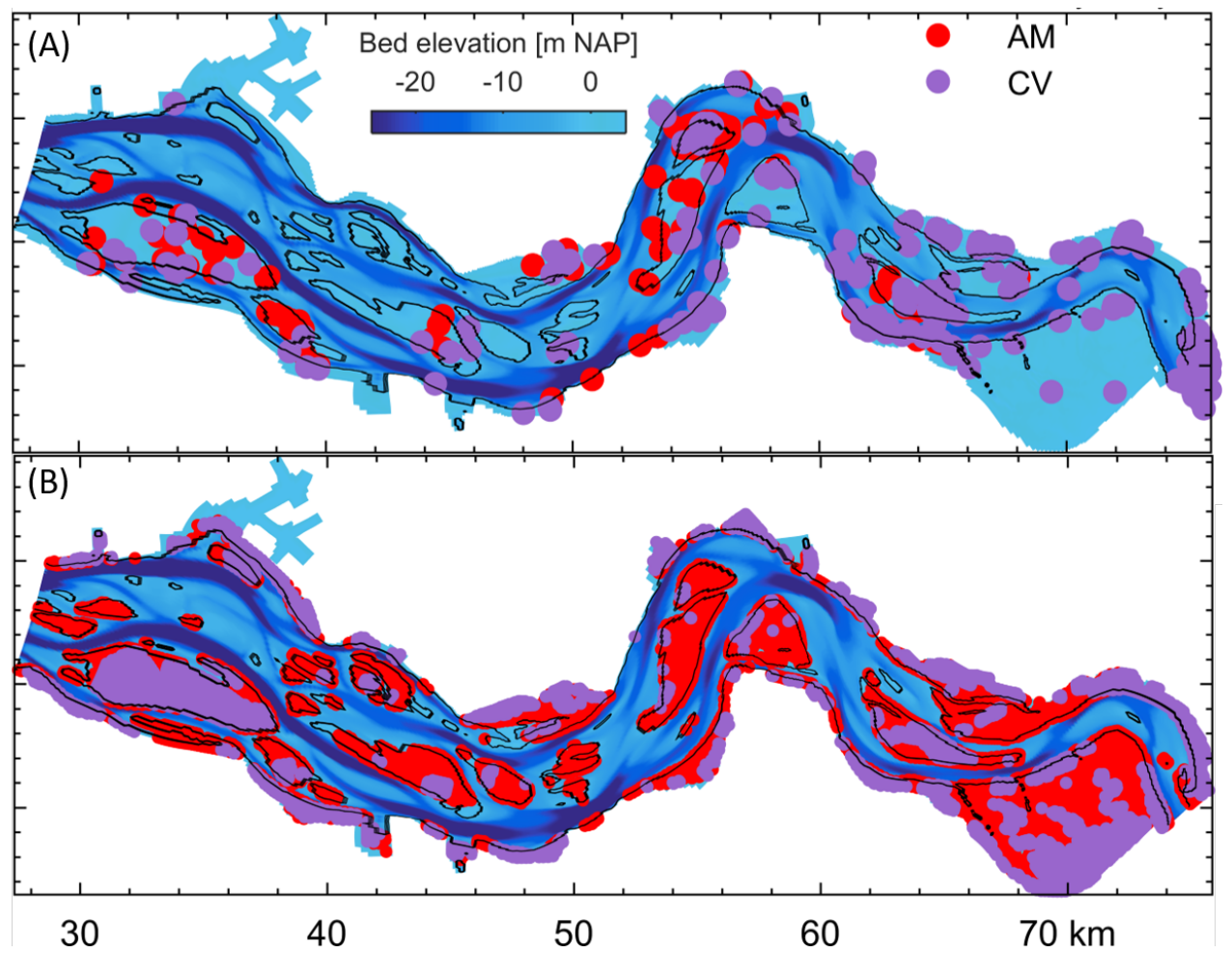

Figure 5.3: Occurrence of $A$. marina (AM) and C. volutator (CV) as presence-absence in the Western Scheldt estuary. (A) is data partly provided by Ysebaert et al. (2002); (B) is the results from the Nevla-model domain for AM and CV (more information on the model in Braat et al. (2019b) and Brückner et al. (2020)) showing similar trends in species predictions.

\subsubsection{Spatial patterns of species abundance and eco-engineering effects}

In the idealized estuary model, each scenario resulted in varying distributions of bioturbators and biostabilizers as a result of the species-specific habitat requirements and eco-engineering effects (Figure 5.4A). While AM was widely abundant in the centre and mouth reaches of the estuary (red colours), CV was restricted to the shores and the bars (purple colours). The combination AMCV led to an expansion of AM towards the upper shores and restricted CV abundance to the centre shorelines of the estuary (red and purple colours Figure 5.4A). In the scenario combining the three species (AMCVMPB), CV and MPB co-existed on the bars and along higher shores (orange colours). In the scenarios with only MPB, the biofilms occurred on bars and along the main channel in the centre and mouth reaches (black colours).

Differences in mud fractions arose between the scenarios with eco-engineers and the reference without species. Scenarios that included bioturbators contained reduced mud fractions, especially along the estuary fringes in the centre and on the bars in the mouth (Figure 5.4B). MPB locally enhanced mud fractions along the main channel and on the bars outside the estuary. Compared to AM, scenarios that included CV led to a larger mud reduction, including the erosion of mud fractions upstream. This suggests that CV determined the resus- 
pension of mud compared to AM. However, the stabilizing properties of MPB in the combined AMCVMPB-scenario lowered erosion along the shorelines in the centre and partly even stabilized the mud on the bars in the mouth.

50 years of morphological evolution led to a significant reduction of the bed elevations along estuarine shores (Figure 5.4C). This effect was most pronounced in scenarios that included CV, implying that CV exerts a major control over the morphology. The eroded sediment was partly redistributed towards the adjacent bars and intertidal areas and partly exported towards the sea. Hence, CV contributed to an increase of mud fractions and bed elevations offshore the mouth area. In comparison, AM led to limited effects on bed elevation change. In contrast, MPB promoted higher bed elevations on the floodplain and along the shores close to the main channel. Since the biologically mediated rate in local sediment erosion led to varying sediment export rates towards the sea, benthic organisms can be important determinants in the retention and export of sediment in and from estuaries.

In Figure 5.5 we compare the results from the dynamic model (E) with the control runs that excluded either eco-engineering effects $(\mathrm{N})$ or both eco-engineering effects and species interactions (N2). This allowed us to quantify the impact of eco-engineering activity and species interactions on the species abundances in multi-species runs. Comparison between the static and dynamic model predictions reveals that the static model results in larger species extent and fractions (Figure 5.5A). AM shows different species abundances between the static and dynamic scenarios. The inclusion of eco-engineering effects significantly reduces species cover predicted by the dynamic model for scenarios including $\mathrm{CV}$, especially in the centre estuary. MPB predictions are independent of eco-engineering effects leading to similar predictions between the dynamic and static models.

Eco-engineering and species interactions benefited the habitat extent of AM and negatively affected CV and MPB in all scenarios (Figure 5.5B). This led to a strong reduction of habitat area for CV and MPB in the multiple-species scenarios. Hereby, the comparison of the $\mathrm{N}$ and $\mathrm{N} 2$ models show that competition and grazing had a lower impact on their abundance than the eco-engineering effects. In contrast, AM occupies less habitat in Figure 5.5B, showing that eco-engineering induces a positive effect on AM. The mean species fraction, describing the density of the species within their habitat, was negatively affected by ecoengineering (Figure 5.5C). This was true for both AM and CV, whereas MPB remained at a fraction of unity in the single-species scenario which was related to the binary formulation in the microphytobenthos model. In the multiple-species runs, however, MPB fractions are reduced both due to grazing and eco-engineering. Surprisingly, CV showed largest fractions in the static model that included species interactions $(\mathrm{N})$. Possibly, the reduction in their habitat area led to a concentration of higher fractions in the remaining habitat.

The control runs predicted larger biota abundance than the dynamic model with ecoengineering for all scenarios but AM. This is due to the different eco-engineering effects changing the morphology: CV resuspends mud and reduces its own habitat, whereas AM is able to maintain and expand its habitat through reduction of the local mud fraction. Thus, in multi-species runs, the expansion of the intertidal area and a redistribution of the mud by the presence of $\mathrm{CV}$ resulted in newly created habitat that could be occupied by associated 


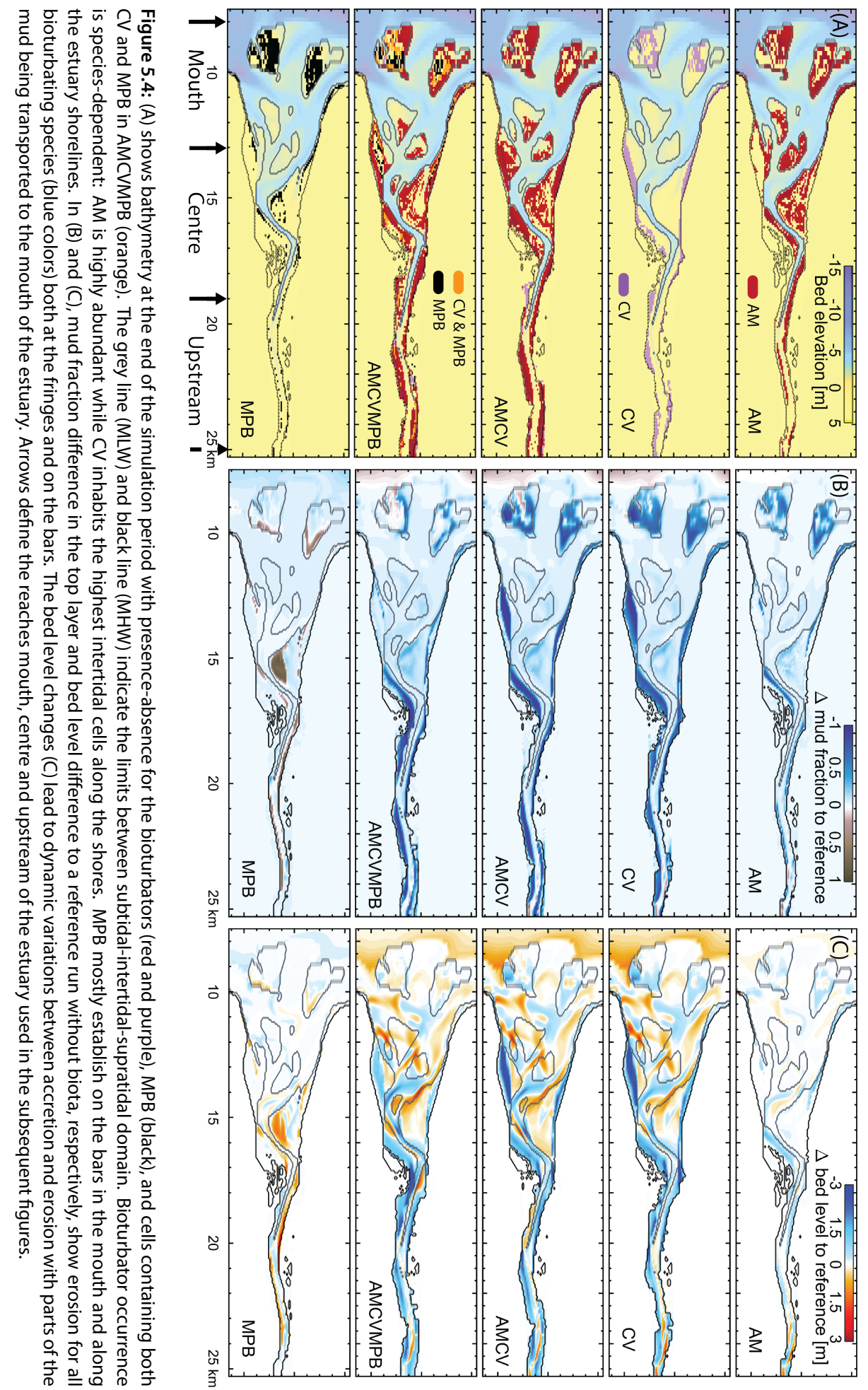


species. However, the species density, here described as species fraction, is negatively affected by the bioturbating activity of both AM and CV. Consequently, the results show that species interactions determine where species can settle, whereas eco-engineering controls habitat suitability.

We compare estuary width, mean mud thickness and relative colonized area along the estuary and along the inundation gradient to study eco-engineering effects and related trends in species abundance (Figure 5.6A-J). The presence of bioturbators leads to a widening of the estuary while MPB locally reduces width compared with the reference scenario (Figure 5.6A). The effects of the species increase away from the mouth of the estuary. Especially under the presence of $\mathrm{CV}$ in the scenarios $\mathrm{CV}$, AMCV, and AMCVMPB, the estuary width increases, which can be related to the erosion of intermediate intertidal elevations between 0.2 and 0.6 of inundation period (Figure 5.6A \& B).

The above trend is also reflected in the mean mud fraction (Figure 5.6B \& G): Along estuary, the reference scenario showed strong variations in mud thickness from a few centimetres up to $0.5 \mathrm{~m}$ in the centre of the estuary. In line with the previous results, AM showed comparably limited variations in mud thickness as opposed to CV, AMCV and AMCVMPB that reduced mud thickness along the entire length of the estuary (Figure 5.6B). CV and AMCV induced strongest effects on mud thickness in the mouth area of the estuary in contrast to scenario AMCVMPB (dark purple) that mainly altered mud in the centre and upstream reach. These variations were likely induced by the presence of MPB that stabilized the mud along the shores in the centre and upstream (Figure 5.4B). These locations coincided with the alterations induced in the MPB scenario at kilometre 15. For the single-species runs (AM, CV, $\mathrm{MPB})$ the along estuarine mud thickness could directly be related to relative colonized area (Figure 5.6C-E). For multi-species scenarios, no clear pattern was visible.

Along the inundation gradient, mud thickness reduced from high to low intertidal areas. $\mathrm{CV}, \mathrm{AMCV}$ and AMCVMPB significantly reduced mud thickness at higher intertidal elevations at inundation periods below 0.4 (Figure 5.6G). This trend is proportional with an increasing fraction of AM from single- to multi-species runs, whereas CV is decreasing (Figure 5.6H-I). In contrast, MPB affects intermediate and high elevations even though its occurrence is limited to the lower intertidal, suggesting that eco-engineering mediates cross-shore transport and leads to protection or exposure of the higher intertidal. There is no significant change in MPB between single- and multi-species scenario (Figure 5.6J).

Interestingly, the combination of several species (AMCV and AMCVMPB) led to a shift in biota abundance (Figure 5.6H-J). While CV coverage is significantly reduced, AM migrated to higher bed elevations, probably because of reduced mud fractions at these elevations induced by CV. Similarly, the presence of MPB in AMCVMPB enhanced both AM and CV presence through mediation of the mud content. Astonishingly, these feedbacks induced a shift in the species curves with AM being dominant at higher elevations and CV at lower elevations in the multi-species run (AMCVMPB). Consequently, when multiple species were present, species abundances were affected by individual eco-engineering effects. This means that the emerging species pattern was defined by the new habitat properties emerging from the feedback-loop between eco-engineering effects and species interactions. 


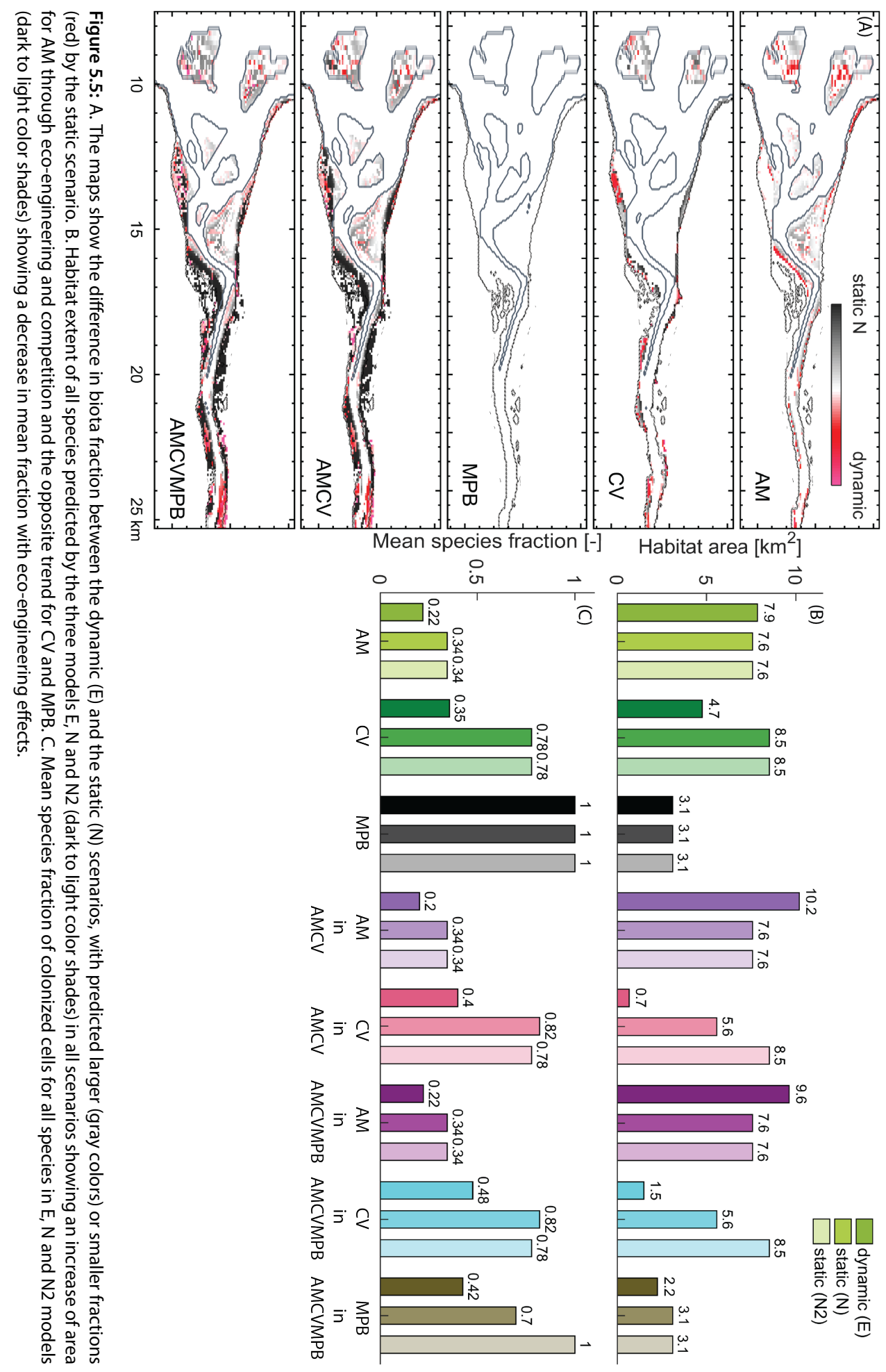



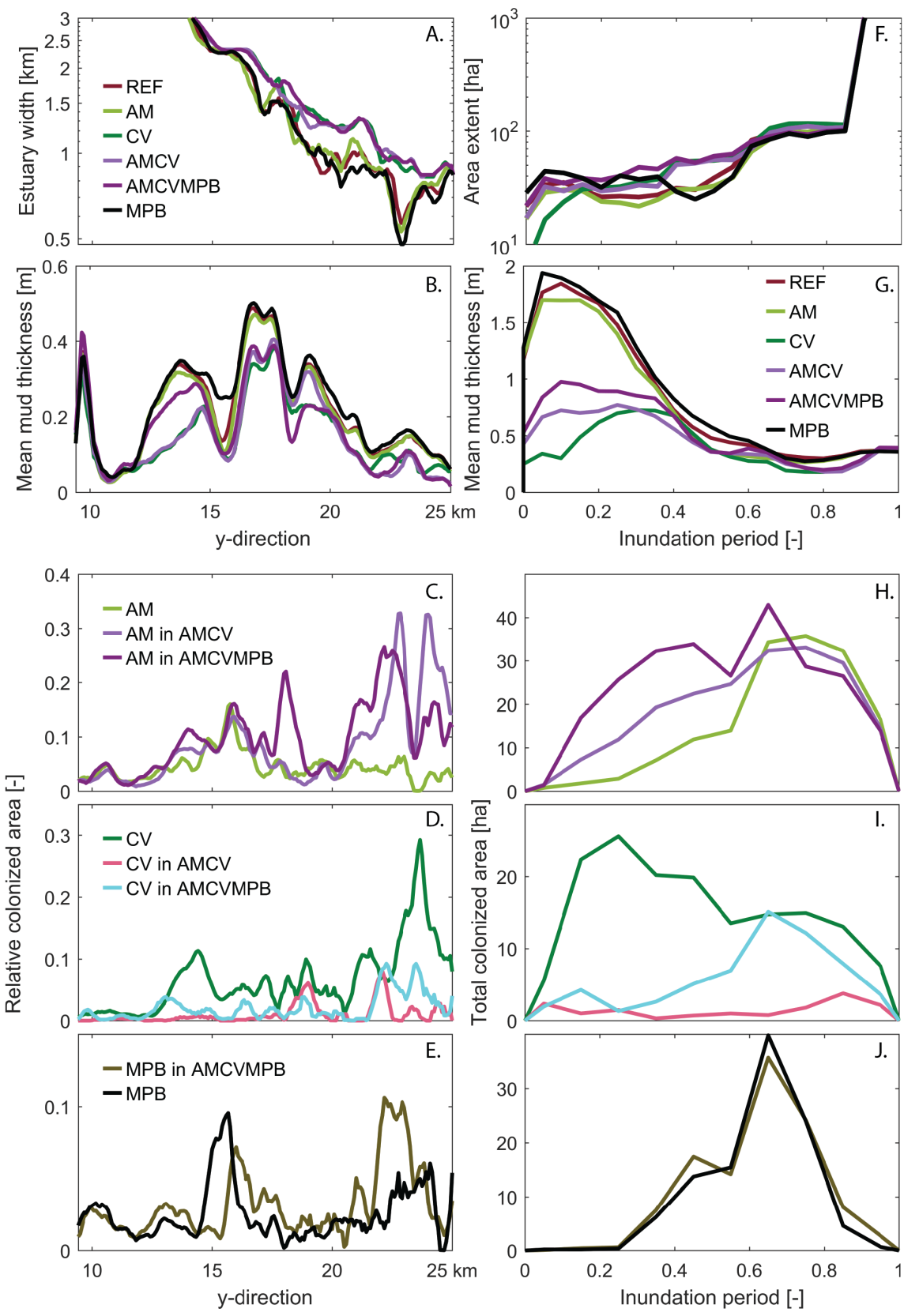

Figure 5.6: Estuary width, mean mud layer thickness and relative species cover along the estuary (A-E) and along the inundation gradient $(\mathrm{F}-\mathrm{J})$ at year 50 for all scenarios showing a widening together with mud erosion along the entire estuary for CV, AMCV and AMCVMPB and accretion by MPB while AM has marginal effects. When multiple species are present, species abundances of AM and MPB are locally enhanced while CV abundances reduce. The new abundances result from an additional feedback between eco-engineering effects and species interactions and lead to a redistribution of species along the inundation gradient. Please note the logarithmic $y$-axis in panel $A$ and $F$. 
The biota-induced changes observed in Figure 5.4 led to varying effects on the hypsometry across the three reaches of the estuary (Figure 5.7A). Large bed level changes occurred under $\mathrm{CV}, \mathrm{AMCV}$ and AMCVMPB. Especially, the upstream and centre reach in these scenarios showed increased erosion of the higher intertidal elevations, which led to a smoothened hypsometric curve. AM induced a similar trend but to a lesser extent. On the other hand, MPB increased the bed levels in the upstream and centre reach with largest accretion around and above mean water $(0 \mathrm{~m})$. In the mouth, the concavity of the hypsometric distribution was enhanced especially by CV and AMCV. Overall, the effects on bed elevation distribution were greatest in the upstream and centre reach compared with the mouth area, possibly linked with increasing sediment availability provided from erosion in adjacent areas.

The bar plot (Figure 5.7B) quantifies morphological changes for the three reaches of the estuary between the biota scenarios and the reference scenario. Comparison of the mud thickness and tidal area extent revealed how strongly sediment was resuspended through eco-engineering along the tidal gradient. The effect of AM and MPB were small in general with greatest effects in the intertidal and limited effects in the supratidal area. In contrast, scenarios including CV strongly reduced mud in the supra- and intertidal domain by close to $50 \%$ in the upstream and the centre reach. As a result, supratidal area extent decreased, leading to an increase in intertidal and subtidal area extent. The eroded mud partly settled in the subtidal area raising local mud fractions or was transported downstream. In the mouth, more than $50 \%$ of the mud was eroded in the intertidal by CV and AMCV compared to the control run, leading to larger mud thickness in the subtidal for AMCV. Interestingly, MPB in the AMCVMPB scenario protected the intertidal mud from erosion with increasing effects towards the centre and mouth of the estuary. Our findings (Figure 5.7) show that the efficient bioturbator $\mathrm{CV}$ promoted regional effects across the estuary by exposing the supratidal domain and promoting lateral expansion of the estuary. On the other hand, the moderate bioturbator AM and microphytobenthos mostly affected local sediments, having a smaller impact on estuarine evolution.

\subsection{Discussion}

\subsubsection{Eco-engineering and species interactions determine species abundance}

The results of the multi-species scenarios revealed new emerging species patterns compared to the single-species scenarios. When $\mathrm{CV}$ is present, the dominant species AM expands its habitat (Figure 5.4A, 5.5 \& 5.6): the eco-engineering effect of CV promotes an advantageous modification of the morphology for AM, allowing for migration of AM towards higher intertidal elevations. Similar successive behaviour can be observed in marine vegetation with pioneer species colonizing harsh environments and through their habitat modification allow colonization by successive plant species (Bertness and Pennings, 2002; Townend et al., 2011). This mechanism can lead to the disappearance or migration of pioneer vegetation and alters species composition. On the other hand, competitive effects reduce the abundance of $\mathrm{CV}$ along the entire tidal gradient. Consequently, competition effects do not only constrain recessive species growth but affect the feedback loop between eco-engineering and hydromorphology, which governs species community structure. Surprisingly, when MPB is intro- 

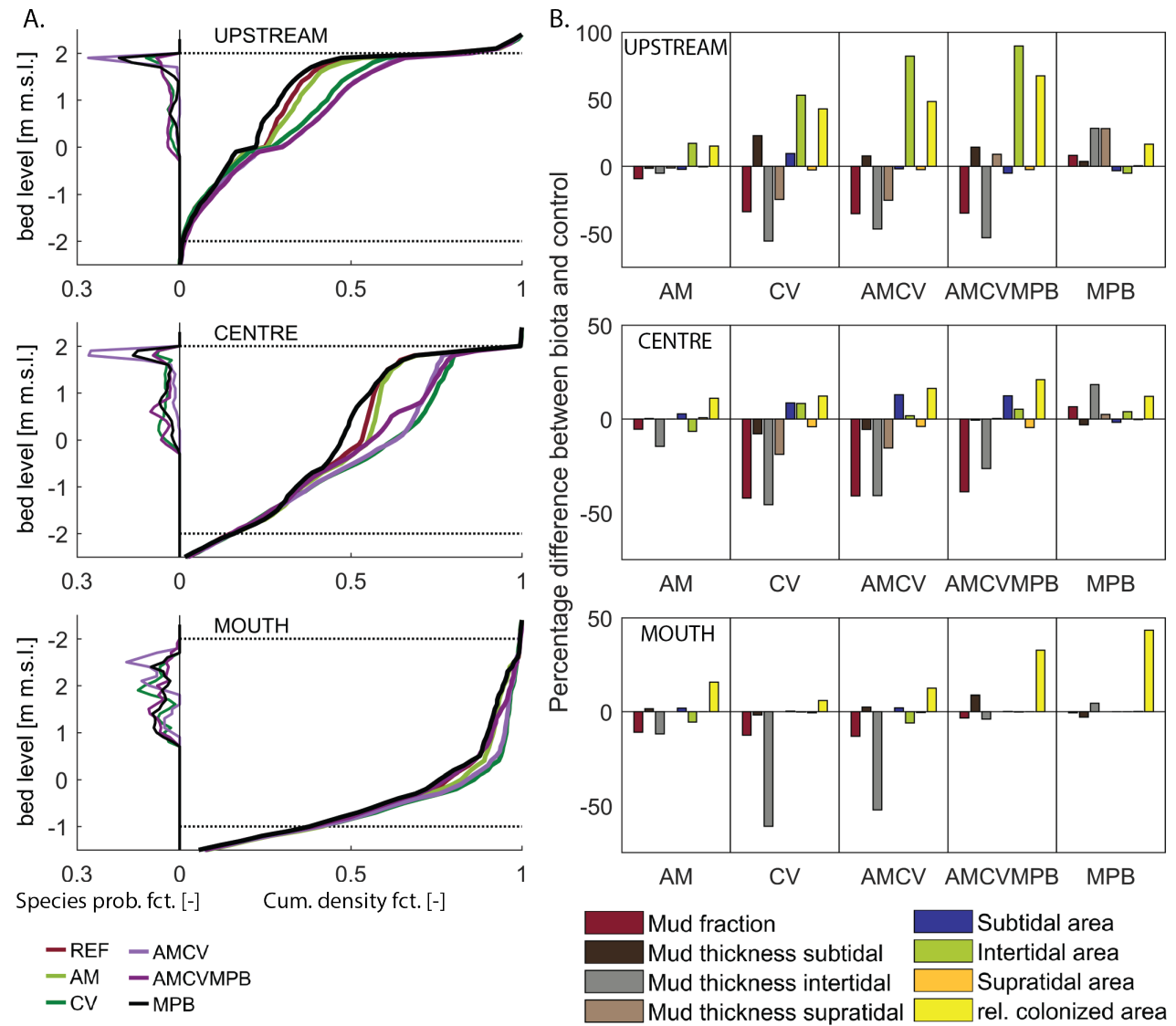

Figure 5.7: Hypsometric curves per reach for bins of $0.2 \mathrm{~m}$ (right axis) as mean values and biota probability function (left axis) for each estuary reach show largest biota-induced effects in the upstream and centre reach of the estuary. Dotted lines represent high and low water. (B) Mud fraction, thickness, tidal area extent and colonized areas per reach. Bars are relative to the values in the reference run.

duced to the model, both AM and CV are able to expand as MPB locally stabilizes the mud, which enlarges the suitable habitat for both bioturbators (Figure 5.6). New zonation patterns emerge, suggesting that overall species distribution is the result of four combined factors: species-specific habitat preferences, habitat modification, competition and grazing. Hereby, eco-engineering effects appear to be especially important for species abundance and ecosystem dynamics (Figure 5.5). The feedback loop between species interaction, eco-engineering effects and environment has wide-ranging implications for species growth and morphology. Eco-engineering effects are important for species diversity in ecosystems as they promote a variety of habitat and facilitate niche development (Crooks, 2002). These results imply that species interactions have measurable effects on the large-scale morphology of tidal environments.

The model of the Western Scheldt estuary predicts trends in bioturbator abundance observed in the data: The model and field data both show the presence of A. marina on the 
lower elevations closer to the channels, whereas C. volutator occurs along higher elevations at the shores and on top of the tidal bars (Figure 5.3). The larger abundances in the model result from omitting the salinity gradient in species predictions that in the field data constricts $\mathrm{CV}$ abundances closer to the mouth and AM upstream. Moreover, the differences in data sampling locations and timing explain the reduced abundances in the field data compared to the model results. Despite the divergence between the model and field data regarding the overall abundance of species, the model correctly predicted the species distribution trends as observed in the data.

In the idealized estuary, the model can represent species-specific occurrence along the inundation gradient as reported in Ysebaert et al. (2002), Cozzoli et al. (2013), and Fang et al. (2019): CV grows in high fractions in hydrodynamically calm locations on top of the bars and at the higher elevations along the shores of the estuary, AM occurs at intermediate intertidal elevations in the downstream estuary (Figure $5.4 \& 5.6 \mathrm{H}$ ). This trend is in line with species descriptions in literature that report a medium density along large parts of the crosssectional gradient of A. marina and high densities of C. volutator (Beukema and De Vlas, 1979; De Backer et al., 2011; Fang et al., 2019). As a result, the model allows to explore the isolated and combined effects of the eco-engineering species on the morphology with the idealized scenarios.

\subsubsection{Eco-engineering affects reach-scale morphology}

The eco-engineering effect of the species is to alter mud distribution in the estuary that feeds back on species growth: a negative eco-engineering effect of $\mathrm{CV}$ causes potentially restricted occurrences through high resuspension, whereas a positive eco-engineering effect by AM maintains its habitat by resuspending superfluous mud from the top layer (Figure 5.4 \& 5.6). This mechanism can also be observed in marine vegetation, where dense vegetation cover leads to higher inundation times or ponding, which eventually restricts vegetation to expand or enhances their mortality (Brückner et al., 2019). The bioturbation scenarios represent combined grazing activity and resuspension by movement and reproduction behaviour (Le Hir et al., 2007), hence, a potential maximum effect induced by the bioturbators. As a result, the bioturbation represents ideal conditions for bioturbator activity, assuming sufficient food, absent seasonal variability and neglecting predators. The model results are informative for estuaries that are subjected to maximum biostabilization and biodestabilization effects under ideal conditions, but also elucidates the trends in estuaries under less ideal conditions for benthic species through competition and grazing.

We observe regional variations between mud erosion and bed level change magnitudes in the reaches of the estuary (Figure 5.6 and 5.7). Previous studies have shown that the equilibria between bioturbation and biostabilization determine seasonal mud content and bed elevations on intertidal flats (van de Koppel et al., 2001; Herman et al., 2001; Widdows et al., 2004). The presence of biogenic structures, such as shells or protruding structures from burrows, tracks and mounds, can alter the roughness of the sediment and creates local turbulence. These effects are highly density and species dependent, possibly creating local skimming flow that reduces near-bed roughness and therefore exceed the scope of this paper (see Friedrichs et al. (2000)). We observe the strongest effects of eco-engineering in the 
upstream and center estuary, resulting from the combination of local species abundances, eco-engineering efficiency and hydrodynamic stresses.

In the mouth, mainly AM occurs, which is characterized through low bioturbation efficiency and mainly sandy habitat. Furthermore, relatively higher hydrodynamic stresses through large tidal prism have a larger effect on the morphology of the mouth (Corenblit et al., 2007). Although Volkenborn et al. (2007) showed that the presence of A. marina can lead to system changes between muddy and sandy flats, suggesting that bioturbators can have wide-ranging effects on system state, the model predicts strong localized effects. This trend evolves from the low mud availability in its mostly sandy habitat combined with low bioturbation efficiency. Consequently, AM exposes a smaller mud fraction and leads to local morphological changes constrained to the intertidal zone. Overall, the effects of AM are smaller compared to the pronounced erosion induced by CV. However, resuspension of sandy sediments under bioturbation was only indirectly accounted for in the model with erosion of sand-mud mixture for mud percentages larger than $40 \%$ (Van Ledden et al., 2004). With this assumption we exclude the morphological effects of species bioturbating sand in the dynamic parts of the estuary that possibly enhances changes in the morphology of the mouth area.

The largest morphological effects occur in the upstream and centre estuary, where CV occurs in calm, muddy areas. Resulting from the upstream erosion, mud is transported towards the mouth but does not accrete on intertidal bars and shores (Figure 5.7). Instead, the mobilized mud is transported offshore. The upstream erosion also increases intertidal habitat. However, the newly created habitat is not colonized by CV since the reduced mud content constitutes uninhabitable habitat for CV (Figure 5.7 \& D.2). On the other hand, MPB stabilizes the intertidal domain upstream and in the centre (Figure 5.7). As a result, a reduction in mud transport towards the channels leads to reduced mud export while bed levels can be maintained or locally increased. Consequently, large-scale morphological response is governed by local effects that depend on both the efficiency of the bioturbator in resuspending mud as well as the available mud in their habitat. Hence, the overall potential of the bioturbator to induce modification of system-scale morphology is determined by a combined effect of species density, species-specific bioturbation potential and habitat characteristics.

When multiple species are present, morphology is determined by the efficient bioturbator CV. The morphology of the estuaries evolving from scenario CV and AMCV have similar bar pattern (Figure 5.4), bed level distribution (Figure 5.7) and mud content (Figure 5.6). Even with low relative abundances, as AM is the main competitor but with lower bioturbation effect, the presence of CV determines morphology. Consequently, species dominance seems to be secondary in multi-species environments, whereas presence of species with strong ecoengineering efficiency is the decisive factor on how the overall morphology evolves. This is similar to the concept of 'keystone species' that have a disproportionately large effect on environmental modification (Power et al., 1996). We therefore confirm that bioturbation efficiency defines the potential of a species to alter their habitat and, independently of abundance, strongly contributes to the morphological evolution of estuaries. 


\subsubsection{Eco-engineering affects large-scale morphology}

The morphology of the estuary is altered by eco-engineering such that the estuary shifts from an exporting system under bioturbation to a depositional system under biostabilization (Figure $5.4 \& 5.7$ ). Local bioturbators determine total mud content of the estuary through controlling resuspension of mud deposits that are exported towards the sea. This results in an overall sandier environment under the two contrasting bioturbators as well as their combination. On the other hand, biostabilization retains mud in the estuary by protecting the intertidal mud from erosion (Figure 5.4B).

Consequently, species-specific resuspension and stabilization lead to contrasting erosion patterns. These modified sediment erosion rates in turn determine bed elevations, affect bank slopes and therefore control slope failure. If bioturbator-induced erosion is large, i.e. in scenarios with CV, supratidal erosion increases intertidal floodplain extent, whereas lower floodplains transform into subtidal environment. As a consequence the estuary widens laterally (Figure 5.6A \& F). In contrast, lower resuspension by AM transforms the intertidal into subtidal area, reducing floodplain and bar extent without promoting lateral erosion of the estuary. Biostabilization on the other hand protects the banks and promotes local mud accretion, which raises lower intertidal bed elevations. As a result, the trends in large-scale morphological evolution are governed by the dominance of either biostabilizers or bioturbators. These findings confirm that potential shifts from bioturbator- to biostabilizer-dominance, for example induced by global warming, can affect estuarine evolution, not only locally but also at the large-scale (Widdows and Brinsley, 2002).

When biostabilization is governing the system, we observe channel confinement and increasing mud content, whereas the presence of destabilizers leads to channel erosion and lateral expansion (Figure 3.3). Under bioturbation, overall mud content in the system is reduced. When multiple species are present, biostabilizers locally promote bed accretion but overall channel erosion prevails. In addition, the species distribution is affected, leading to a restructured zonation of species in the system.

A positive feedback-loop emerged between increasing MPB occurrence on mud and subsequent enhanced mud stabilization. This causes seasonal stabilization of mudflats (van de Koppel et al., 2001; Le Hir et al., 2007; Orvain et al., 2012b). The mean stabilising effect by MPB leads to a long-term effect on mud and morphological stabilization. Previously reported modeling results showed that seasonally growing MPB has limited effects on long term bed elevation change as mud gets washed away in winter (Le Hir et al., 2007). However, in subtropical regions or warmer climate, persisting biostabilization possibly allows for long-term mud accretion in dynamic estuaries (Day et al., 2013). Furthermore, waves also affect the distribution of benthos. Here our models represent sheltered systems by seaward spits or barrier islands with limited exposure to offshore and wind generated waves. The absence of waves in the model allows for MPB establishment on the bars in the mouth where mud can settle. However, in exposed systems those seaward reaches are affected by waves and possibly limit both mud content and presence of MPB.

Previous modeling studies investigating eco-engineering effects through vegetation on the large scale observed that infilling and stabilization in the centre of the estuary led to confine- 


\section{A) Biostabilizers dominant}

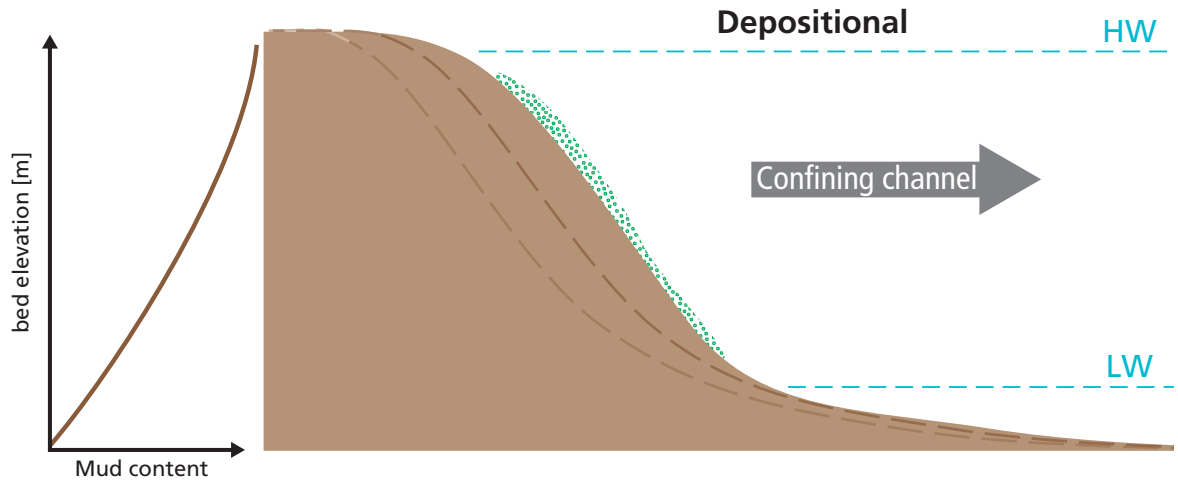

B) Biodestabilizers dominant

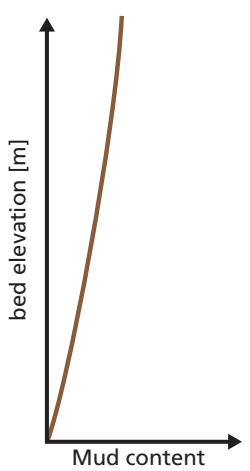

\section{Erosional}
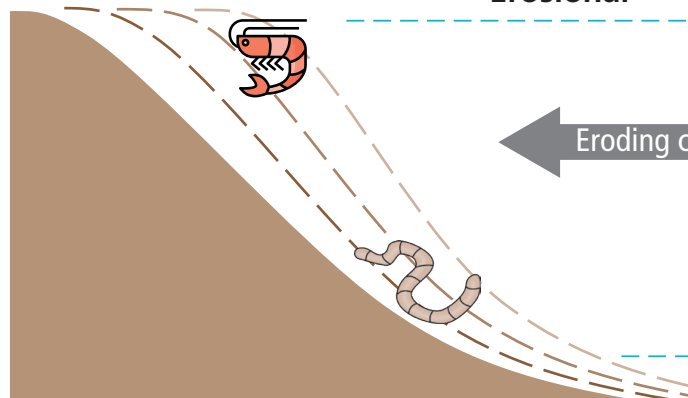

C) Combination of bio(de)stabilizers

Erosional
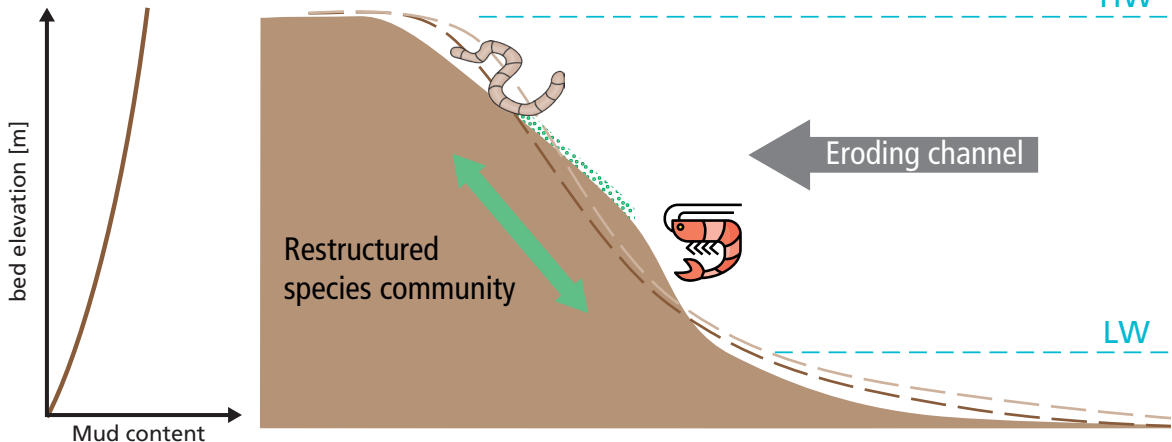

Figure 5.8: Conceptual channel adaptation and mud content in an estuary dominated by biostabilization (A), biodestabilization (B), and a combination of biostabilization and -destabilization (C). A) a depositional system evolves that develops confining channels with overall increasing mud content and steeper slopes; (B) and (C) promote an erosional systems with lower mud content and gentle slopes, allowing for lateral channel migration. Local biostabilization in (C) partly counteracts the erosional trend. Adapting morphology and species interactions lead to a restructured species distribution. 
ment of channels and impeded landward erosion (Lokhorst et al., 2018; Kleinhans et al., 2018). MPB shows a similar trend, whereas bioturbation enhances landward erosion. Possibly, systems that include both vegetation and benthic organisms experience mud accretion by vegetation in the higher intertidal areas while low to intermediate intertidal elevations evolve erosion-deposition patterns induced by alternating microphytobenthos and bioturbator cover. However, species interactions between vegetation and macrobenthos can have additional effects on local species dominance. For instance, van Wesenbeeck et al. (2008) found that presence of $A$. marina can inhibit saltmarsh establishment linked with the high erodibility of the sediment while A. marina growth is prevented by roots and compaction within the salt marsh sediments. Similarly, seed predation of pioneer vegetation can inhibit vegetation establishment on intertidal flats (Zhu et al., 2016b). This wide range of interactions impairs predictions of species effects in multi-species environments and requires further research.

\subsubsection{Species shifts affect morphological adaptation}

Especially in the face of a warming climate, we need a more detailed understanding of the morphological response of estuaries to varying eco-engineers as we expect future species shifts due to habitat degradation, biodiversity changes or species invasion (Dippner et al., 2010). Climate and human-induced changes will lead to significant effects on local ecosystems and consequently estuarine morphology. Especially macrobenthic organisms were reported to respond to changing environmental conditions. At the same time, field studies have reported a high sensitivity of macrobenthic organisms to climatic changes and external disturbances (Van der Wal et al., 2008; Singer et al., 2016; Kröncke et al., 2013; Reise et al., 2007; Kristensen et al., 2014). For example, increasing temperatures or sediment input can cause significant changes in species communities (Pillay et al., 2008; Dippner et al., 2010). We show that species presence affects the local and the large-scale morphological development of estuaries (Figure 5.7). Hence, our results suggest that the response of benthic eco-engineering species to climate change can be critical to the evolution of estuaries.

\subsubsection{Microplastic pollution in estuaries can be mediated by eco-engineers}

The dynamics of estuarine morphology determines the settling and transport of pollutants, such as heavy metals and microplastics that are usually associated with mud deposits. Especially in recent years, the deposition of microplastics (MP) (diameter several millimeters or smaller) was identified as a key component of soil contamination, posing a threat to marine life and human health (do Sul and Costa, 2014). Estuaries are suspected to be one of the key sinks of microplastic deposition owing to the proximity to the river input and tendency to trap lightweight sediments in the intertidal and supratidal zones (Corcoran, 2015).

Recent studies showed that accumulation of MP's can statistically be attributed to the distance from a source as well as the properties of the local sediment, such as mud content and grain size (Ballent et al., 2016; Vianello et al., 2013; Maes et al., 2018; Enders et al., 2019), which would predict that the largest MP deposition may occur close to rivers and in the sheltered intertidal sediments. Relations between MP abundance and mud content gives a general indication for MP occurrence independently of the MP characteristics, such as density, 
material or size (Enders et al., 2019). Associated with eco-engineering activity, sediment resuspension and stabilization possibly determines MP preservation of sediment-microplastic mixtures. Flushing time of the estuary can be affected by macrobenthos presence, which acts as an active 'filter' that affects pollutant export (Dürr et al., 2011). As a result, MP will be exported when strong bioturbation is present. In contrast, biostabilizers possibly retain more MP in muddy sediments and enhance residence times on the mudflats on the tidal bars. Moreover, the ingestion of MP's by marine organisms can lead to reduced productivity or be lethal to benthic species (Wright et al., 2013; Besseling et al., 2013; Hope et al., 2020). Furthermore, MP can be bio-accumulated along the trophic chain up to humans. Consequently, MP presence can reduce bioturbation efficiency and could change overall morphological response.

Our modeling in conjunction with the above arguments imply that the presence of ecoengineers has a potentially significant effect on where microplastics settle and accumulate in the system. Based on the observations in the literature and the reasoning above, we expect that there will be a delayed response of the morphology to the supply of MP in estuaries. At first, bioturbators resuspend the MP from the upstream reaches such that it is distributed in seaward direction and possibly captured in the high intertidal zones. As the MP accumulate, the toxicity may reduce the macrobenthic population, which could lead to more trapping at the cost of reducing macrobenthos abundance. This effect may propagate to higher trophic levels leading to ecosystem deterioration. This response has important implications for identifying main areas of pollution in estuaries that can threat marine life and human health. On the other hand, future research on microplastic occurrence needs to take into account resuspension of benthic species to quantify pollutant retention in estuaries and how they are exported towards the marine realm.

\subsection{Morphology and macrozoobenthic species respond to sea level rise in es- tuaries}

This section is a brief pre-publication of the preliminary results of this modeling study, which was conducted with the macrozoobenthos model developed above in Section 5.2, to which the reader is referred to for methods and for explanation of the modeled species. While the analyses are far from complete, the results are novel and relevant for the final discussion.

The feedback between eco-engineers and hydro-morphodynamics determines both species pattern and co-evolving morphology of estuaries (Brückner et al., 2020). Sea level rise promotes an adaptation of the estuarine morphology, which similarly affects the habitat of various species occupying estuarine sediments (Townend and Pethick, 2002; Leuven et al., 2019). These enhanced stresses on eco-engineers can potentially lead to the disappearance of many species that are not capable of adapting to their fast-changing environment. Abundant research has been carried out on the response of tidal marshes and wetlands to sea level rise (e.g Kirwan et al., 2016; Schuerch et al., 2018; FitzGerald and Hughes, 2019; Xie et al., 2020), showing that many wetlands have the capacity to adapt to rising sea levels under sufficient sediment supply. However, limited research is available that investigates how macrozoobenthic biodestabilizers are able to adapt to changing sea level rise rates. Possibly, they can sim- 
ilarly adapt to the degradation of their habitat through their eco-engineering activity. Alternatively, macrozoobenthos might migrate towards more suitable habitat or disappear entirely from the system. To improve our understanding on the responses of abundant macrozoobenthic species to projected sea level rise rates, we apply our novel eco-morphodynamic model to an idealized estuary domain. We test simplified, generic representations of two abundant biodestabilizers in northwestern Europe, Arenicola marina (AM) and Corophium volutator $(\mathrm{CV})$, under low, fast and extreme sea level rise rates (SLRR). Low SLRR is $0.5 \mathrm{~cm} /$ year, high SLRR $1 \mathrm{~cm}$ /year, and extreme SLRR 2cm/year (Church et al., 2013; Slangen et al., 2014). The scenarios compute 100 years of morphological adaptation and species abundance is updated every morphological month, similar to the coupling in Section 5.2.

The model results show that varying sea level rise rates lead to different morphologies and species abundances after 100 years of simulation time (Figure 5.9). The progression of the tidal channels towards the upstream estuary in the control run (REF) is clearly visible from low to extreme SLRR (Figure 5.9A-C). Along with the widening tidal channels, the species migrate upstream and towards the sides of the estuary with increasing SLRR. The upstream migration leads to reduced total species cover as of the smaller floodplains in the upper estuary. While AM occupies mainly the mouth and center of the estuary and moves towards the floodplains along the sides of the estuary under high and extreme SLRR, CV thrives along the shores of the estuary and migrates upstream, but the limited tidal floodplain extent at extreme SLRR strongly reduces their habitat. Although the channels widen with increasing sea level, lateral erosion is not strong enough to create extensive floodplains in the upper estuary. This is likely because the riverine mud supply is not high enough to counteract the increasing tidal amplitude (Dunn et al., 2019; Leuven et al., 2019). In sheltered areas, species can survive high and extreme SLRR as seen by the constant presence of species within the southern tidal embayment close to the mouth (Figure 5.9A-C). The dynamic tidal-bar pattern, however, does not allow for species establishment on the bars and forces the species to occupy the sheltered intertidal areas along the shores in the center and upper estuary.

In comparison with the control run (REF) the presence of bioturbators enhances channel erosion, leading to the formation of several smaller channels with tidal bars. Moreover, the erosion of the floodplains allows channel to migrate further towards the sides of the estuary. Especially in the scenarios with $\mathrm{CV}$, erosion of the floodplains leads to lower elevations towards the sides of the estuary, promoting sediment transport towards the mouth and increasing tidal bar extent.

Mud content (solid lines) decreases with time and with increasing SLRR (Figure 5.10) due to the increasing tidal prism that increases channel dynamics and sediment export from the estuary. The decreasing mud content results in a decline in the number of cells colonized by CV (dark green dashed lines), a species that prefers muddy habitat. Similarly, the mixed scenario AMCV shows decreasing abundances (purple dashed lines). In contrast, AM expands its habitat with sea level rise rates, possibly because they thrive in the increasingly abundant sandy habitat (light green dashed lines). As a result, around year 30, the declining trend of AM abundance stabilizes or reverses, resulting in a widening colonized area. A similar trend has been predicted for the Humber estuary, where sea level rise might lead to species loss based on salinity protrusion into the estuary (Fujii and Raffaelli, 2008). These findings 

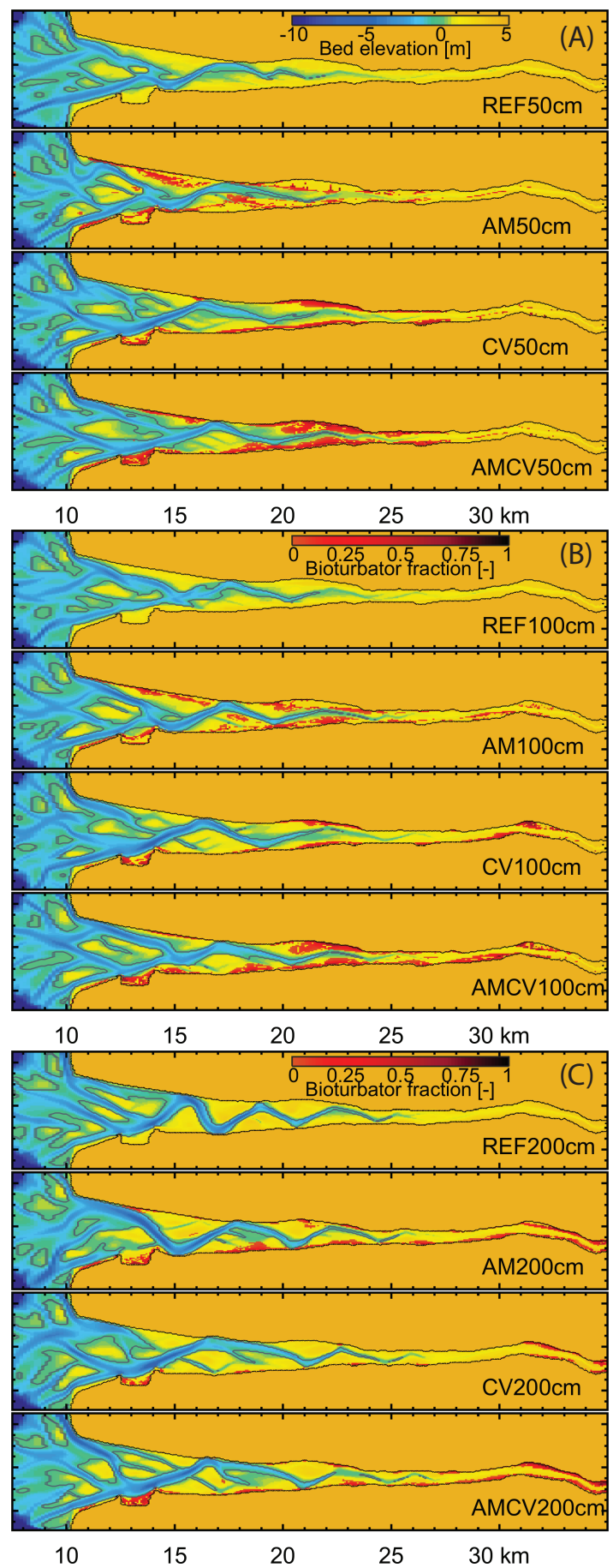

Figure 5.9: Maps of species abundances (red) on bed elevations for the three sea level rise scenarios reveal tidal channel widening and upstream migration of the species with increasing SLRR (A. low; B. high; C. extreme). 
suggest that in addition to biochemical stresses on macrozoobenthos, the alteration of the physical habitat leads to feedbacks on specific species and can induce a species shift.

\subsection{Conclusions}

This research shows that benthic eco-engineers can have large-scale effects on the morphology of estuaries. To understand the eco-engineering effects of two macrobenthic species and microphytobenthos, we built a novel eco-morphodynamic model that combines a hydromorphodynamic model in Delft3D with a dynamic species growth model. We ran model scenarios in an idealized estuary domain with a dominant sand-prone moderate bioturbator, a recessive mud-prone efficient bioturbator and microphytobenthos in isolation and in combination.

The model showed that the presence of an efficient bioturbator reduced mud thickness and bed elevations in the upstream and centre reach of the estuary through erosion of the supraand intertidal areas. Consequently, the estuary widened laterally. In contrast, a moderate bioturbator mainly affected the intertidal areas at the mouth of the estuary. We found that this contrast resulted from a combination of the bioturbation efficiency of the species and the mud available within their habitat. In runs with multiple interacting species, the morphology is mainly controlled by the efficient mud-prone bioturbator, even though their abundance is small due to habitat constraints and species interactions. On the other hand, biostabilization by microphytobenthos confined the estuary by protecting the banks from erosion and, hence, facilitating mud accretion in the estuary. Overall, bioturbation led to mud export towards the sea whereas biostabilization retained mud within the estuary.

Eco-engineering creates suitable habitat for co-existing species, whereas species interactions determine their abundance. The mud-prone bioturbator reduces the mud content in the higher intertidal area, which increases habitat quality for the sand-prone species. Subsequently, once the sand-prone species colonizes the modified areas, it outcompetes the mudprone bioturbator. As a result, a species shift is induced in the upper intertidal where the mud-prone bioturbator is replaced by the dominant sand-prone species. On the other hand, microphytobenthos enhances mud fractions in multi-species runs at intermediate elevations, which in turn facilitates the expansion of the mud-prone bioturbator.

Eco-engineers modify the large-scale morphology of estuaries, whose abundance is determined by both physical habitat modification and by species interactions. As a result, changes in the species community may have wide-ranging effects on the response of estuarine morphology in terms of mud export to coastal seas and lateral erosion of estuaries under changing conditions. Climate change, human usage and pollutants, such as microplastics, exert pressures on the ecosystem with still unknown consequences and feedbacks that are imperative to future investigation.

Sea level rise causes the development of estuarine morphologies characterized by dynamic channel bar patterns and reduced mud content. These trends are enhanced under the presence of biodestabilizers and feed back on their abundance. The erosion of intertidal flats forces the macrozoobenthos to move from areas close to the channels towards higher and 

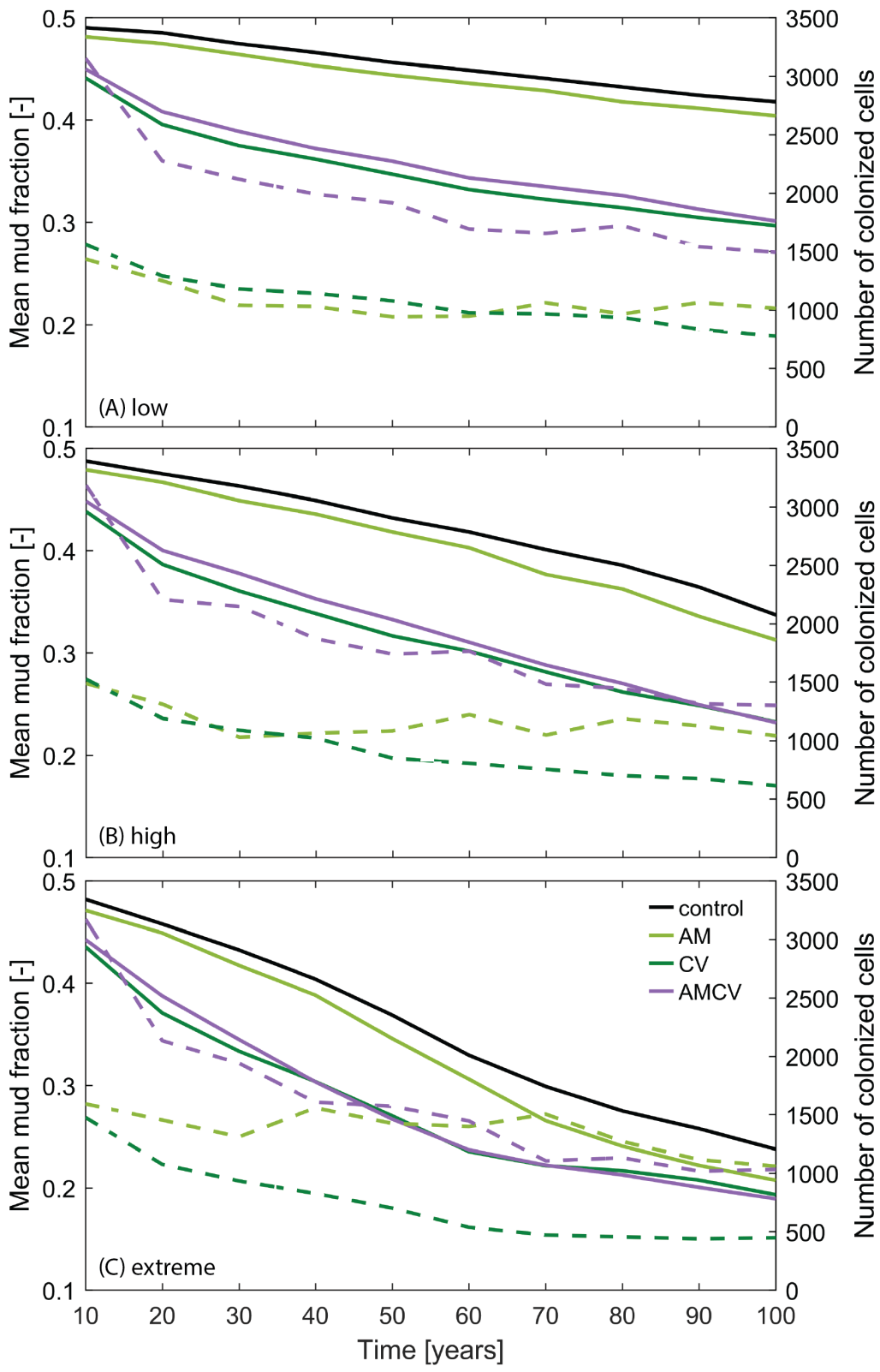

Figure 5.10: Mean mud fraction (solid lines) and number of colonized model cells (dashed lines) for the four model scenarios and the three sea level rise rates show a decline with simulation time. The mean mud fraction decreases from the low SLRR scenario (A) towards the high (B) and extreme SLRR scenario (C) with the steepest slopes in (C). The number of colonized cells stabilizes for AM and decreases for CV and AMCV towards the high (B) and extreme SLRR scenario (C). 
more sheltered elevations. With increasing mean water levels, the species migrate towards the upper estuary. If suitable floodplains exist, the species can colonize upstream habitat but limited intertidal area extent causes a species decline. Moreover, the results suggest that increasing sea level rise has contrasting effects on the prevailing species: a mud-prone macrozoobenthic species is threatened because of the decreasing mud content of the estuary, whereas a sand-prone species thrives in increasingly sandy habitat. The resulting species shift towards the less efficient biodestabilizer AM, possibly mitigates the erodibility of the sediment with sea level rise and might result in reduced lateral erosion of the estuary.

\section{Acknowledgements}

We thank the reviewers for careful reading and contribution to the quality of this work. This research was funded by the ERC Consolidator project 647570 and Utrecht University. The model files and codes are available in the supplementary material. The Nederlands-Vlaams-Model was created and calibrated by Deltares. Delft3D is an open source code available at this site (https://oss.deltares.nl). We want to thank Dr. Maarten Zeylmans for his help with the data and Dennis Dekker for preliminary testing of the model. Special thanks go to Dr. Tom Ysebaert for providing the field data to validate the model predictions. MZMB designed the study, developed the model, carried out the simulations and analyses and drafted the manuscript; CS participated in the set up of the model and in the data analysis, and critically revised the manuscript; GC coordinated the model scenarios and helped draft the manuscript; $\mathrm{AB}$ participated in the design of the models and revised the manuscript; MBA supported the model simulations and revised the manuscript; MGK conceived and coordinated the study, participated in the analyses and revised the manuscript. All authors gave final approval for publication and agree to be held accountable for the work performed therein. 


\section{Chapter 6}

\section{Muddying the waters: Paleozoic land plants caused irreversible changes to estuarine sedimentation}

The Paleozoic evolution of vegetation transformed terrestrial landscapes, facilitating novel sedimentary processes and creating new habitats. This transformation left a permanent mark on the sedimentary record, perhaps most strikingly through an upsurge in preserved terrestrial mudrock. Whereas feedbacks between evolving vegetation and river structure have been widely studied, Paleozoic estuaries have so far received scant attention. As the junctions between the land and sea, the co-evolution of estuarine morphology and vegetation traits are fundamentally tied to a varied range of geochemical cycles, and pass inference on how global silicate weathering patterns may have varied over time. Here we employ an eco-morphodynamic model with an in-built vegetation code to simulate estuarine morphology through five key stages in plant evolution. An abiotic model (early Precambrian?) saw mud deposition restricted to fortuitous instances of limited erosion along bar-flanks. Estuaries colonized by microbial mats (Precambrian onwards) facilitated accretion that sufficiently strengthened bars to spark extensive mudflat development. Small-stature, rootless vegetation (Silurian-Early Devonian) introduced novel above-ground baffling effects, which led to notable mud accumulation in quiescent environments. The incorporation of roots (Early Devonian) strengthened these trends, with root structures serving to decrease the mortality of occupying plants. Once the full complement of modern vascular plant architectures had evolved (Middle Devonian), dense colonization promoted the formation of in-channel islands accompanied with system-wide mud accumulation. These simulations suggest estuaries underwent profound change during the $\mathrm{Pa}-$ leozoic, with the greening of the continents triggering processes and feedbacks which render all predating source-to-sink sediment pathways non-uniformitarian.

Based on: Muriel Z.M. Brückner, William J. McMahon and Maarten G. Kleinhans (2020). Muddying the waters: Paleozoic land plants caused irreversible changes to estuarine sedimentation. In review: PALAIOS. 


\subsection{Paleozoic facies shifts}

The mudstone content of Precambrian terrestrial strata is limited (Long, 2011; Long, 2019; McMahon and Davies, 2020), with markedly heterolithic deposits only becoming abundant in the Paleozoic (Davies and Gibling, 2010; McMahon and Davies, 2018) (Figure 6.1). This muddying of the continents occurs in stratigraphic alliance with the paleobotanical record, with the shift attributed to the ways in which vegetation enhanced mud production and sediment flux from continental interiors (McMahon and Davies, 2018). Plants serve to increase the production of mud directly through enhanced chemical weathering (e.g. Hazen et al., 2013). They also facilitate mud retention on the continents through ecosystem engineering (Jones et al., 1994) which induces: 1) sediment-baffling, the trapping by above-ground plant parts and deposition of suspended sediment through flow deceleration within vegetation structures (Moor et al., 2017; Kleinhans et al., 2018); and 2) sediment-binding, the stabilization of grains by roots (Xue et al., 2016). The bulk of studies which have considered the ties between evolving land plants and the muddying of the continents have focused on the impact of riparian vegetation on riverine processes. Estuaries, conversely, have scarcely been considered; a glaring omission considering these environments were likely gateways for the terrestrialization process (e.g. Strother, 2000; Rubinstein et al., 2010). The purpose of this short paper is to test the biophysical possibility that Paleozoic land plants altered the morphological development of tidal environments, presently inferred only from partial modern analogues (e.g. van de Vijsel et al., 2020) and studies of ancient outcrop belts detached from their formative processes by hundreds of millions of years (e.g. Bradley et al., 2018; Muhlbauer and Fedo, 2020). Understanding the precise timings and magnitudes of accelerated terrestrial mud deposition coeval with expanding vegetation cover is fundamental for a range of studies including: 1) controls on deposition in the absence of vegetation (e.g., during the Precambrian Earth, on Mars); 2) mechanisms which enabled continental terrestrialization; 3 ) the capacity of early land plants to engineer their habitats; and 4) functional changes to geochemical cycles which are dependent on sediment-flux.

\subsection{Modeling the sedimentological impact of Paleozoic land plants}

Using a numerical model for an idealized estuary, we parametrized vegetation growth and sensitivity to environmental pressures and the eco-engineering effects of vegetation on physical processes through five distinct Paleozoic 'vegetation stages' (VS) (Figure 6.1). The idealization and control enabled exact quantification of species effects, whilst excluding the intricacies of real world systems with complex controls outside the scope of this paper. Our vegetation stages, amended slightly from previous workers for the purpose of appropriate modeling (Davies and Gibling, 2010), mark major advances of vegetation as observed in the paleobotanical record: 1) abiotic (early Precambrian?); 2) biofilms (Precambrian-Cambrian); 3) small-stature, rootless vegetation (Silurian-Early Devonian); 4) tracheophytes (Early Devonian); and 5) arborescent vegetation with deep roots and high resilience to external stresses (Middle Devonian). A numerical model that couples a vegetation code to a hydro-morphodynamic estuary model (Delft3D) was developed to address the sedimentological impact of 


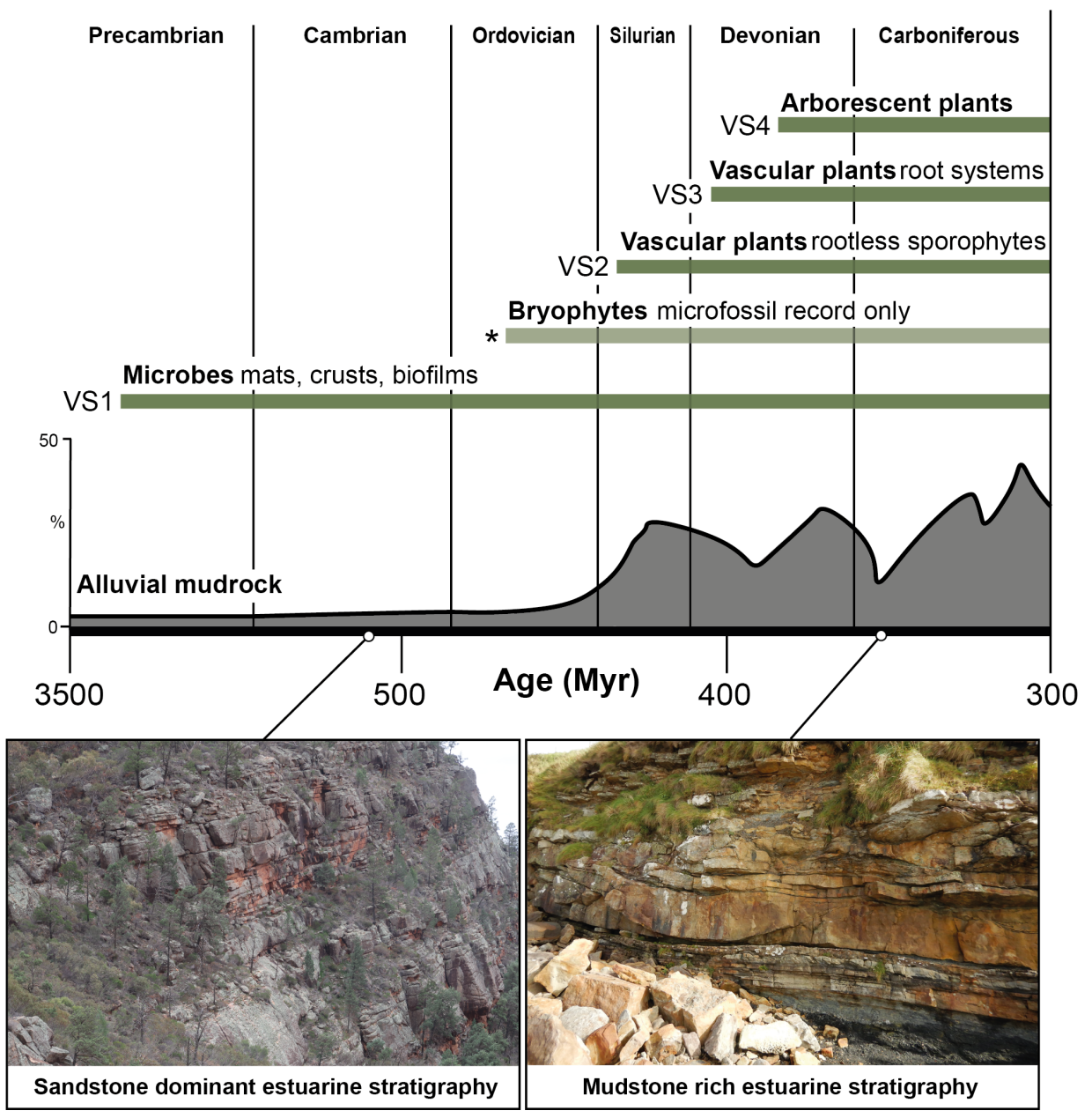

Figure 6.1: Key evolutionary advances of land plants (vegetation stages (VS)) (Boyce and Lee, 2017; Fischer, 2018). Even though bryophytes colonized landscapes as early as the Middle Ordovician (Rubinstein et al., 2010) $(*)$, we neglect this stage as effects of microscopic plant remains (predominantly cryptospores) cannot be parametrized by the model. Mudrock curve redrawn from McMahon and Davies (2018). Photographs of estuarine successions show sandstone prevalence before vegetation (Rawnsley Quartzite, Australia) and widespread mudstone following the greening of the continents (Shawly Formation, Ireland) (Graham et al., 2014). 


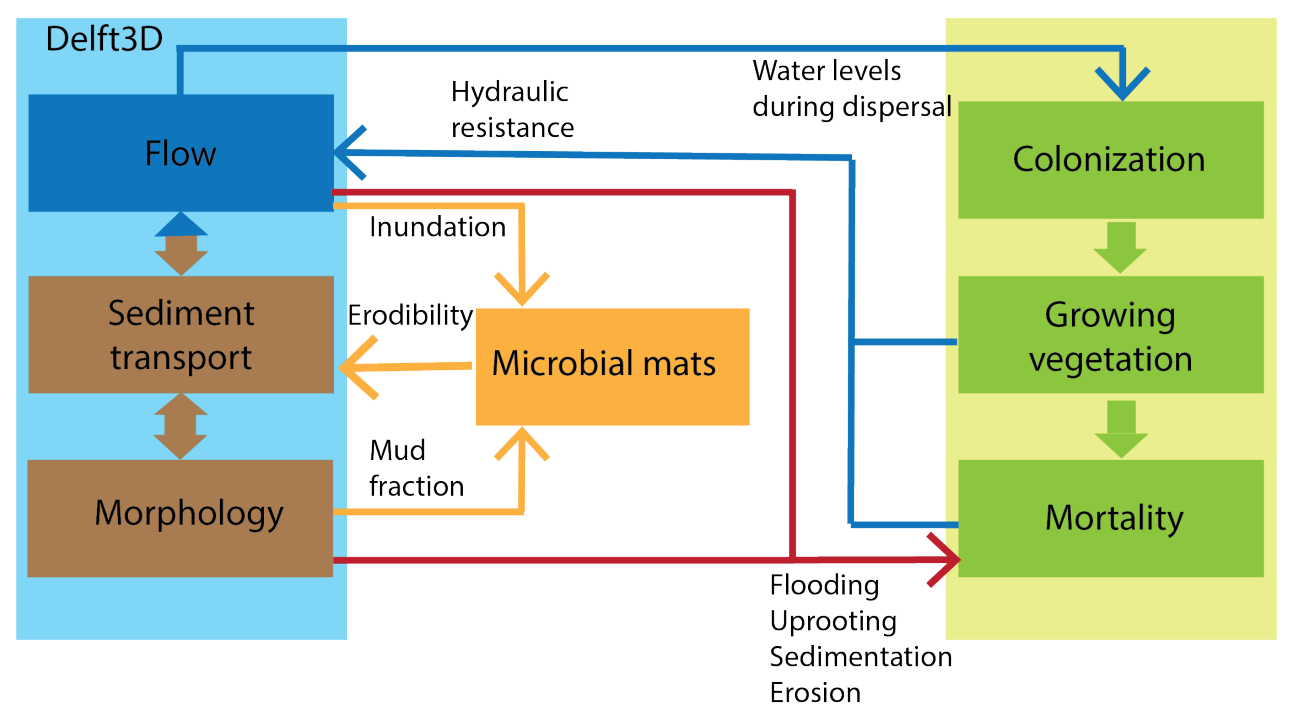

Figure 6.2: Conceptual model of the interactions between the hydro-morphodynamic model (Delft3D) and the vegetation code (from Brückner et al. (2019)). The hydro-morphodynamic computations are used in the vegetation code to determine occurrence of the microbial mats and colonization and mortality of the vegetation. Eco-engineering effects are included through reduced erodibility of the mud by presence of microbial mats and increasing hydraulic resistance with vegetation presence and growth.

evolving land plants (Supplementary Information). Our model captures the feedbacks between ecological and morphological processes by predicting dynamically changing vegetation cover based on environmental parameters. Moreover, the presence of biota affects the hydro-morphodynamic processes in the model through eco-engineering effects. Ecoengineering is captured by different parameters, depending on whether microbial mats or vegetation are present: the presence of microbial mats reduces the erodibility of the mud, whereas vegetation structures alter the flow through hydraulic roughness and drag, indirectly protecting the bed through flow baffling (Brückner et al., 2019) (Figure 6.2). Any direct impact on the mechanical stability of sedimentary substrates caused by root structures was not incorporated (Kleinhans et al., 2018). The vegetation code and the hydro-morphodynamic model are coupled every sixth month of morphological computations, to update the biota distribution based on the environmental parameters and to feed the resulting change in erodibility or hydraulic roughness and drag back into the Delft3D model. Derived plant characteristics (Figure 6.2 \& Figure 6.3) enabled computation of feedbacks between vegetation establishment, growth and mortality, and hydromorphology, concurrently enabling analysis of vegetation's impact on sedimentation.

We tested a generic species representative for each vegetation stage in isolation in order to generalize the potential impact of evolutionary traits on mud percentages and estuarine morphology. Each model run is carried out under consistent settings (boundary and initial conditions, run time, coupling with the vegetation model) in a macrotidal environment with riverine mud supply. The model neglects any impact on mud production through boosted 
chemical weathering. This set-up enabled direct comparison between the scenario results at the end of a simulated period of 300 years (a sufficient time-period to detect biomorphological change). The estuarine landscape is realistic in morphological and sedimentological properties (van de Lageweg et al., 2018; Brückner et al., 2019) and for the first time allows systematic testing of biogeomorphological processes and their sedimentary products.

\subsubsection{The vegetation stages}

\section{Vegetation stage 0 (VSO)}

VS0 includes no biological components, serving as a control run against which the impact of subsequently evolving microbiota and land plants can be measured.

\section{Vegetation stage 1 (VS1)}

Prior to the advent of land plants, Earth's terrestrial surfaces were not entirely barren, with reports of microbial life in coastal settings extending as far back as the Neoarchean (e.g. Noffke et al., 2006). The mats protect muddy sediments in intertidal areas through the secretion of biofilms, which were computed in numerical cells with inundation periods between 0.3-0.8 and mud content $>30 \%$ (Daggers et al., 2018).

\section{Vegetation stage 2 (VS2)}

VS2 begins in the early Silurian and marks the global development of vascular plants (e.g. Gensel et al., 2001; Gensel, 2008). Vegetation types were characterized by diverse, centimeterhigh sporophytes which lacked roots and only had limited resilience to external stresses.

\section{Vegetation stage 3 (VS3)}

VS3 is marked by the Early Devonian appearance of roots (e.g. Gensel and Berry, 2001; Gensel et al., 2001; Kenrick et al., 2012; Matsunaga and Tomescu, 2016). Early root structures may not have matched all the characteristics of extant land plants, but likely performed the same functions and certainly extended down considerable depths into substrates (Xue et al., 2016). Moreover, flora was characterized by increasing plant sizes and frond complexity, making them increasingly resistant to external stresses.

\section{Vegetation stage 4 (VS4)}

VS4 marks a number of significant evolutionary advances, including the first evidence of arborescent plant forms (Meyer-Berthaud et al., 2013), the earliest trees (Berry and FaironDemaret, 1997), and the first true forests (Stein et al., 2007; Stein et al., 2012; Stein et al., 2020; Berry and Marshall, 2015). Whilst VS4 has a Middle Devonian lower limit (Davies and Gibling (2010) [their VS6]), the upper limit is not defined and extends well into the Carboniferous (Davies and Gibling, 2013). Their increasingly complex life-cycle leads to the emergence of pre-mature and mature life-stages characterized by increasing plant and root sizes (Figure 6.3) and even greater resilience to environmental pressure. 


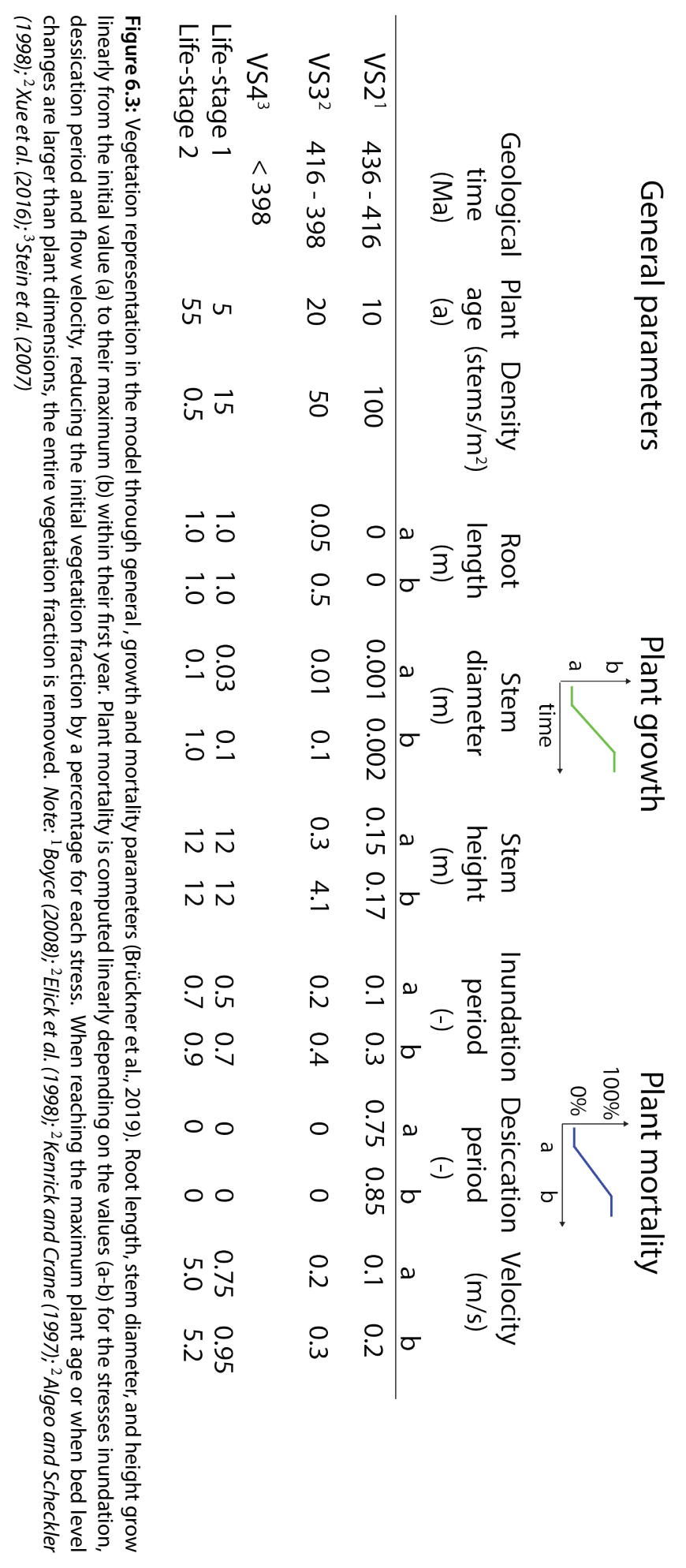




\subsection{Results}

\subsubsection{Vegetation evolution affects mud accretion in estuaries}

The abundance of vegetation, and their capacity to retain mud, varied depending on VS and positioning along the tidal energy gradient (Figure 6.4 and Figure E.1).

\section{Vegetation stage 0}

Mud was dominantly transported towards the ebb delta (Figure 6.4), with fine-sediment retained on the continent largely limited to sheltered areas of the estuary (e.g., channel banks, bar-tops) (Figure 6.4B, Figure 6.5).

\section{Vegetation stage 1}

Microbiota colonized extensive floodplain tracts in the middle estuary, as well as on tidal bars within the lower estuary (Figure 6.4). In the middle estuary, high rates of mud deposition limited sediment transport towards the ebb delta (Figure 6.4B). Overall, biofilm-induced stabilization added sufficient strength to in-channel and bank-attached barforms to facilitate the development of extensive muddy floodplains in conjunction with erosion of the main channel bed (Figure 6.5).

\section{Vegetation stage 2}

The small-stature, rootless vegetation had little effect on upper estuarine processes, with mud being dominantly eroded and transported towards the ebb delta (Figure 6.4A-B). In the middle estuary, which constitutes more quiescent conditions overall, flow baffling by above-ground plant parts was far more pronounced, with flow-velocity being sufficiently reduced to promote mud capture and forced deposition. Increased retention of cohesive mud elevated local topography, reducing overland flow strength and further stabilizing the landscape (Figure 6.5). Mud fraction was directly correlated to colonized cells, demonstrating that their ecosystem-engineering effects only impacted local settings (Figure 6.4C).

\section{Vegetation stage 3}

Increased resistance against autogenic reworking due to the advent of roots and greater plant sizes led to more colonization and subsequent mud capture within the middle and lower estuary (Figure 6.4A). Mud accretion occurred on both in-channel bars and the outer-flanks of the middle-estuary, with sediment-baffling increasingly pronounced due to a more substantial above-ground biomass. Although mean mud concurrent with colonized areas rose, total estuarine mud content was not significantly enhanced (Figure 6.4B-C). Vegetation largely occupied channel banks, while tidal bars remained dynamic and were only sparsely colonized. Bank stabilization focused flow into the main channels and off floodplains, enhancing the degrees of channel incision (Figure 6.5). Both channel incision and increasing floodplain elevation through mud deposition gradually reduced mud transport towards the intertidal zone, instead promoting mud export towards the ebb delta. 


\section{Vegetation stage 4}

Complex phenotypes with deep roots facilitated the expansion of vegetation and promoted deposition of muddy sediment on bars and banks. The middle and lower estuary were most substantially affected, with lowered plant mortality promoting the development of dense forests on lower estuary floodplains and tidal bars (Figure 6.4A). Such greened areas were capable of withstanding significant hydrodynamic pressure, with enhanced mud stabilization leading to the first true vegetated islands. Mud deposition markedly decreased down-system towards the lower-estuary, with muddy sediments being primarily captured in mud-flats towards estuary flanks (Figure 6.4B). Moreover, extensive vegetation cover resulted in systemwide mud preservation, as opposed to the localized effects felt in VS2-3 (Figure 6.4C). The extensive stabilization of estuarine banks caused deeper incision and steeper channel margins (Figure 6.5).

\subsection{Baffling by vegetation induced a rise in Paleozoic mudrock}

\subsubsection{Flow baffling depends on plant resilience}

Before the Paleozoic expansion of vegetation, biofilms may have had a pronounced impact on estuarine mud accumulation. Whilst the local sediment stabilizing effect of microbiota in tidal environments has been widely recognized (e.g. Widdows et al., 2004; Le Hir et al., 2007), any system-wide impacts are understudied. However, using the modeled estuary here, we can infer that the encroachment of microbiota on intertidal flats led to localized but significant mud accretion. As in extant estuaries, vegetation size and density control mud accretion (Leonard and Luther, 1995; Brückner et al., 2020), such that increasing vegetation coverage throughout the Paleozoic likely induced further mud preservation. The capacity of plants to expand their habitats from sheltered to dynamic environments is owed to: 1) increased resilience to external stresses through the evolution of roots; and 2) their increased flowbaffling capacity due to enlarged above-ground dimensions. This resulted in the amelioration of land plant adaptations, changes which forged key new habitat spaces for subsequently evolving fauna and thereby new morphologies.

The importance of rooting varies with system size and style (e.g. Perona et al., 2012) and whilst the mechanically binding-effects of roots play an important part in stabilizing moderatesized banks, in cases where channel dimensions vastly exceeded root length, systematic undercutting is likely to have been prevalent (Kleinhans et al., 2018). By the Carboniferous, complex root strategies come with resilient, dense plant fractions that promoted sediment stability and aggradation of islands. By reducing plant mortality, the development of significant roots was key in the encroachment of vegetation towards more dynamic estuarine environments, subsequently causing substantial modifications to source-to-sink sediment transport.

\subsubsection{Ecosystem Engineering on the rise}

Our modeling efforts feed into debates concerning the capacity for early vegetation types to ecosystem-engineer their habitats (Davies et al., 2017; Santos et al., 2017). Santos et al. (2017) 

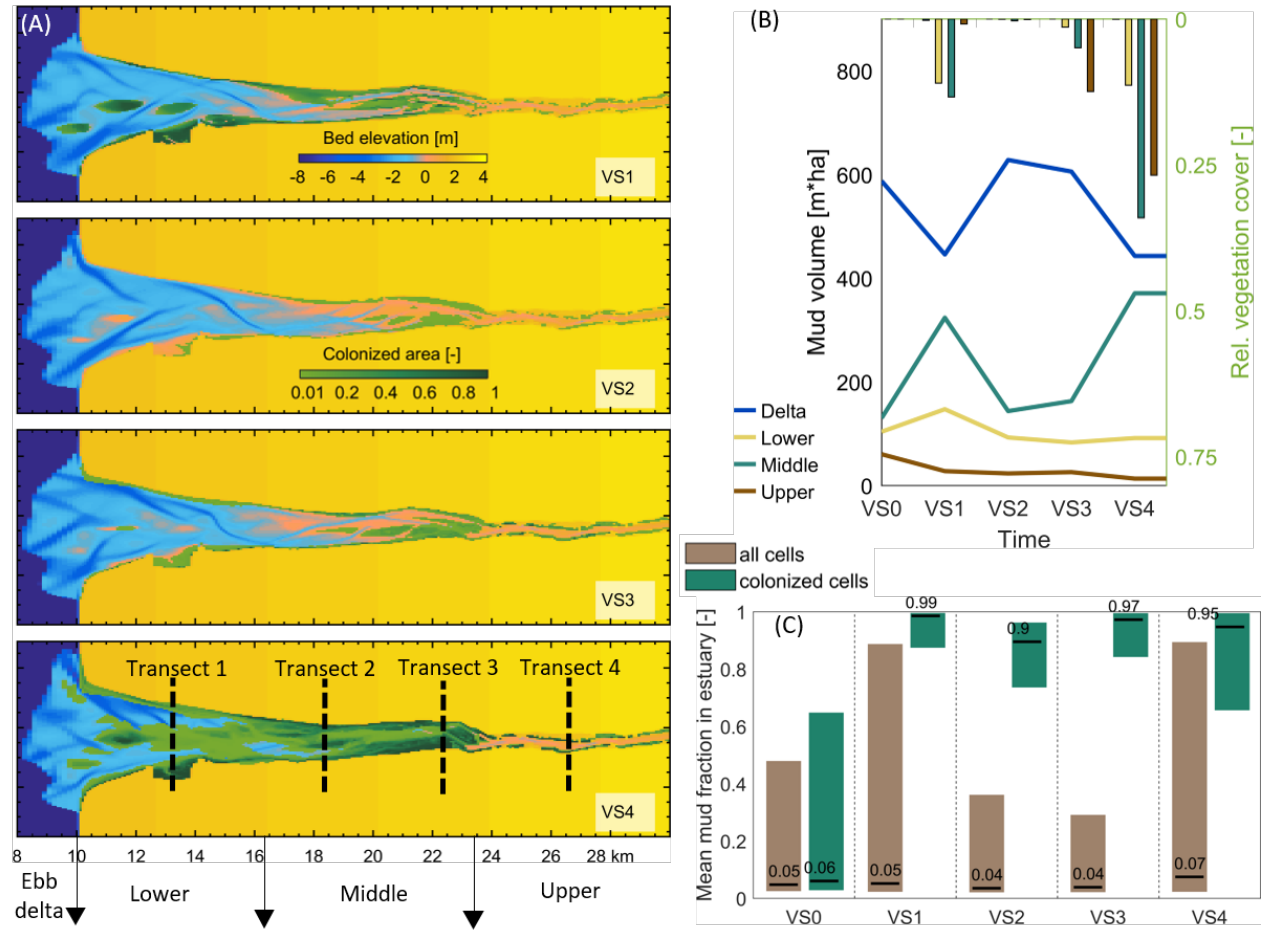

Figure 6.4: A) Bathymetry and mean relative vegetation coverage [1/a] over the simulation period (fraction multiplied with growth period) for all scenarios, showing large coverages for biofilms (VS1) and increasing vegetation abundance through VS2-VS4. B) relates stored mud volume along estuary (lines) and relative colonized area to entire intertidal domain (bars). Biofilms (VS1) enhance mud retention, particularly in the middle estuary. Whereas increasing vegetation complexity has little effect on the upper estuary, mud is captured in the middle and lower estuary, leading to reduced mud export towards the ebb delta. C) compares overall mean mud fraction (brown bars) and mean mud fractions in colonized cells (green bars), illustrating that mud is captured within vegetated patches and eroded when vegetation dies-off for VS2-VS3 (in contrast to the system-wide retention of mud in VS1 and VS4). The green bar in VS0 represents the mean mud in the cells colonized in the other scenarios as a control. Bar bottom and top are 25- and 75-percentiles, respectively, black line shows median mud fraction.

provided an abiotic account for Earth's tangible rise in Paleozoic mudrock (Figure 6.1). In their model, a specific continental configuration was linked to increased tropical weathering and thus heightened quantities of mud production. Critical to this model was the notion that primitive rootless land plants were likely ill-equipped to modify sediment flux substantially, a hypothesis here suggested untrue. Early rootless land plants may have been adequately equipped to engineer their landscapes through flow-baffling (Figure 6.5), with the evolution of novel plant-obstacles heightening the deposition of suspended sediment. Any retained cohesive material would lead to increases in the elevation of the local topography, alterations which served to further reduce overland flow velocity and facilitate additional mud deposition. 

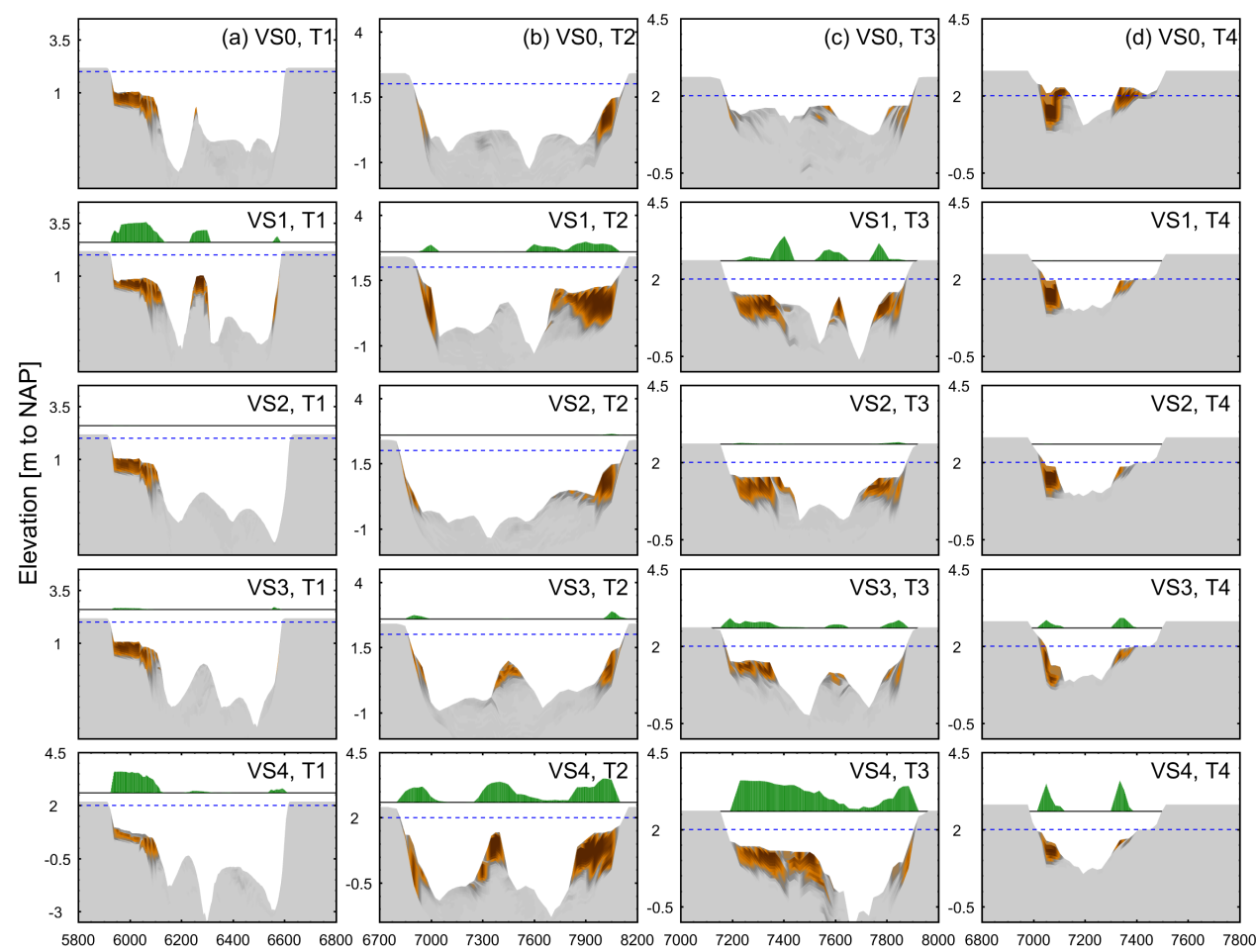

Figure 6.5: Cross-sections (marked in Figure 6.4) with mud deposits and qualitative vegetation presence (green bars on black line) for four transects (T1-4). Channel incision and bank slope gradient increases with vegetation complexity while mud and vegetation co-occur along channel banks and on bars from VS3 onwards. Blue dotted line is high water.

\subsubsection{Vegetation baffling reduces mud bypassing}

The evolution of large and complex phenotypes, in combination with deep rooting, led to a shift from locally constrained mud preservation in colonized subenvironments towards the system-wide deposition of mud. Extensive retention of mud within estuaries may have compensated for increased weathering of the hinterland induced by extensive plant cover. This suggests that from the Paleozoic, estuaries no longer acted as a passive sediment bypass to the oceans, a changing system-behavior which has important implications for how we treat Earth's ancient geochemical cycles. In addition to potentially enhancing the infilling process of estuaries, this mechanism could have similarly mitigated changing climatic impacts, such as increasing rainfall and sea level rise that forced drowning or transgression of non-vegetated landscapes.

\subsection{Conclusions}

Numerical models attest that the expansion of terrestrial flora in the Paleozoic induced novel conditions susceptible of extensive mud accumulation in estuarine environments. Perma- 
nent changes to estuarine morphology were promoted by the colonization of microbial mats that enhanced mud accretion on sandy bars and shores (early in the Precambrian). The evolution of primitive, rootless vegetation (Silurian-Early Devonian) birthed new flow-baffling processes which further heightened mud deposition in quiescent environments. By reducing local flow velocities, above ground plant parts promoted bed level accretion and flow deviation towards main channels, better protecting previously exposed areas from later erosion. Following the Devonian invention of roots, mud retention substantially increased, as raised plant resilience to external environmental stresses allowed the generation of new habitat. By the late Devonian, muddy sediment was abundant in all reaches of the modeled estuary, facilitating a shift from a locally constrained mud accrual to a system-wide increase in mud deposition. Consequently, far less mud-grade sediment was bypassed to the marine realm, a transformation in source-to-sink transport that holds significant ramifications for pre-vegetation geochemical cycling.

\section{Acknowledgements}

This research was funded by the ERC Consolidator project 647570 . The authors contributed in the following proportions to conception and design, modeling, analysis and conclusions, and manuscript preparation: $\operatorname{MZMB}(50,100,50,40 \%), \mathrm{WJM}(35,0,30,40 \%)$, and $\operatorname{MGK}(15,0,20,20 \%)$. 
$-1$

| | 


\section{Chapter 7}

\section{Synthesis: Biogeomorphological models infer new knowledge on the morphological evolution of past, present and future estuaries}

The main two objectives of this thesis were to

1) develop a novel dynamic eco-morphodynamic model that includes the feedback between hydro-morphodynamics, distribution of several eco-engineers based on detailed species establishment, growth and mortality rules, and their specific eco-engineering effects, and

2) determine how generic eco-engineers affect estuarine morphology at the system scale in terms of spatial mud and bed level distribution and how these changes relate to species abundances.

The following synthesis places the previous chapters in a broader context of landscape evolution of past, present and future estuaries and evaluates how the findings complement and contribute to the current state of research. First, the novel model approach has provided new insights on how the morphological evolution of estuaries is governed by various functional groups of eco-engineers. Not only do I discuss how to generalize those findings for present estuaries, but also on how the results complement research on the evolution of Holocene and Paleozoic estuaries. Second, I touch upon urgent environmental challenges, such as pollution, climate change and habitat degradation and how we can better understand their impact using the insights from this thesis. Third, I discuss the novelties derived from the presented modeling framework in the context of biogeomorphological modeling. Concomitantly, the reader will find an evaluation of the limitations and future prospects of the presented framework. Finally, I summarize the highlights from my work and outline how they lead to new and exciting research steps to take in the future.

\subsection{Eco-engineers determine estuarine morphology at the large scale}

This work shows that eco-engineers determine how the morphology of estuaries evolves in terms of overall mud content, bed level distribution and intertidal area extent, and whether the estuary is a depositional or an erosional system. Those morphological features govern bank stability, tidal prism, accommodation space and the distribution of ecological habitat, which are important in terms of the ecological functioning of estuaries and economic and social interests, such as shipping, fishing or flood protection (Savenije, 2005; Dalrymple and Choi, 2007). Several functional groups of eco-engineers and their combination affect morphological evolution of estuaries differently depending on their specific traits, interactions, and eco-engineering intensity. Below, I discuss the most important trends derived from the model scenarios. 


\subsubsection{Stabilizing eco-engineers}

Stabilizing eco-engineers, here saltmarsh vegetation and microphytobenthos, stabilize local and large-scale morphologies, promote mud sedimentation and preservation and facilitate mutual species expansion when multiple species are present. In addition to foregoing studies reporting the importance of plant characteristics, such as rooting depth, below-ground productivity and slow or fast colonization behavior (e.g. Kirwan and Megonigal, 2013; Schwarz et al., 2018), for marsh growth and geomorphic response, Chapter 3 and Chapter 4 illustrate that estuarine morphology depends similarly on detailed establishment and life-history traits of saltmarsh vegetation.

In Chapter 3, saltmarsh vegetation can establish in a dynamic sandy estuary with limited sediment supply, producing saltmarsh and mud patterns depending on establishment traits: a mud-prone species that requires mud to establish and a sand-prone species able to establish on sand differ in their establishment timing and how fast vegetation can expand. As a result, the mud-prone, slowly expanding species captures mud gradually, which leads to a wide area covered with thin, ecologically valuable, mud layers. In contrast, the sand-prone species captures large amounts of mud instantaneously, which promotes thick mud layers that become a part of the more permanent morphology. This trend was shown both on an intertidal bar and across the entire estuary. From the differently evolving establishment and mud patterns in response to the two species' traits, we can infer that mud is an important constituent for, but not the main driver of, saltmarsh establishment in dynamic estuaries. Saltmarsh can also establish without prior mud settling, making mud settling and saltmarsh establishment highly dependent on the characteristics of the site and the traits of the prevailing species. Consequently, establishment traits that are representative of different saltmarsh species drive vegetation establishment and expansion and, hence, determine the amount of mud deposited and preserved at the bar- and estuary-scale.

Likewise, different saltmarsh species that were parametrized in detail in the model were shown to drive tidal channel geometry and extent on the spatial scale of an intertidal flat (Chapter 4). Based on dominating saltmarsh species, tidal channels emerged in varying numbers and dimensions comparable to dimensions observed in nature (Marciano et al., 2005). Not only did that affect sedimentation and levee formation, but also drainage capacity and flood-ebb dominance on the marsh. Marsh-scale processes determine friction on the tidal wave, accommodation space, and sediment import or export from the marsh and towards other reaches of the estuary and play a crucial role in protection of the hinterland against flooding (Temmerman et al., 2013; Leonardi et al., 2018). Hence, the observed marsh-scale processes and channel networks induced by vegetation species can affect the hydro-morphodynamics of the larger system. For example, variations in tidal asymmetry and sediment transport from local marshes determine the transported sediment load towards the larger system (Moore et al., 2009). This possibly facilitates species establishment on mudflats adjacent to exporting saltmarshes. Chapter 3 illustrated that the available mud together with the environmental parameters and the establishment strategy of the species determine the rate of species establishment and expansion. As a result, the marsh-scale processes within the estuary potentially feed back towards the system-scale and control further marsh establishment. These feedbacks have major implications for the stabilization of the 
estuarine morphology and, hence, management and resilience against storm events and sea level rise (Leonardi et al., 2018).

These findings highlight two important mechanisms to be considered in estuarine evolution: 1) species-specific establishment and life-history traits determine species establishment, growth and expansion; 2) the morphological response is governed by the resulting marsh pattern through altered mud accretion, mud layer formation and tidal channel pattern, both at the scale of intertidal flats and the entire estuary. With these new insights we can improve mud settling in dynamic estuaries with limited mud supply by, for instance, promoting saltmarsh expansion of species with desired traits. The characteristics of the saltmarsh species determine the speed and pattern of the evolving marsh (Schwarz et al., 2015b; Schwarz et al., 2018) and, hence, mud capture. Increasing mud settling, either locally within dense vegetation patches or gradually with slowly expanding vegetation, can be made use of in realignment projects, flood protection or the restoration of wetlands. Through the enhanced sediment settling on intertidal bars and shores of estuaries, tidal bars are stabilized, which in turn maintain the the position of tidal channels and possibly reduce dredging efforts and flood risk (Townend and Pethick, 2002; De Vriend et al., 2011; Leuven et al., 2018a). In addition to their morphological effect, the expansion of saltmarshes can ameliorate habitat and water quality by reducing suspended loads and increasing nutrient export towards coastal waters (Allen, 2000). The creation of valuable wetlands that form habitat for birds and other endangered species can improve biodiversity and ecosystem functioning. Consequently, the species-specific biomorphodynamic feedbacks within an estuary have strong consequences for morphology and ecology and, hence, can be taken advantage of in coastal management and ecosystem restoration of intertidal flats and estuary-scale morphology.

Saltmarshes act as carbon sinks through biomass production and burial of organic matter in the lower layers of wetland soils (Morris et al., 2012). Since saltmarsh pattern and biomass are determined by the feedback loop between geomorphology and species traits, also carbon storage capacity is controlled by biomorphodynamic feedbacks. Consequently, the understanding of marsh evolution is not only essential for the large-scale morphological response of estuaries, but transcends towards their global role and contribution in mediating atmospheric carbon rates and global warming.

Similar to vegetation, microphytobenthos can enhance mud retention in estuaries (Chapter $3,5 \& 6)$. In contrast to previous studies that primarily found seasonal effects of microphytobenthos on mud accretion (e.g. Widdows and Brinsley, 2002; Le Hir et al., 2007), the modeling in this work showed that seasonal growth of biofilms induces long term mud accretion on a tidal bar (Chapter 3). In Chapter 5, estuary-scale effects of microphytobenthos were investigated, showing that mud was sufficiently protected to prevent erosion of interand supratidal sediments. Local colonization by biofilms can alter system-scale mud erosion pattern and mud transport towards other reaches of the estuary. Likewise, mud export from the estuary is lowered when biofilms are present, promoting sediment accretion and potential infilling of the estuary that can mitigate increasing sea levels (De Haas et al., 2018). This effect was also shown to have the capacity to have altered Paleozoic estuaries (Chapter 6). Encroaching biofilms onto the lands potentially stored larger mud fractions in the stratigraphy, stabilized channels and bars and reduced mud transport towards the oceans. 
This stabilization could have created favorable conditions for vegetation establishment and potentially contributed to the colonization by the first small, primitive land plants (Corenblit et al., 2011).

In line with measurements of increasing sediment stability towards the saltmarsh edge linked with microphytobenhos presence (e.g. Austen et al., 1999), the stabilizing effect of biostabilizers was furthermore enhanced in the model when both microphytobenthos and saltmarsh were present: when both saltmarsh and microphytobenthos established, they mutually enhanced their expansion and, hence, mud accretion. As a result, the effect of microphytobenthos increased with pioneer vegetation establishment that protected the biofilms from erosion. Vice versa, biofilm-induced mud accretion on the tidal bar facilitated saltmarsh establishment through enhanced bed elevations and flow deviation. These positive feedbacks between microphytobenthos growth and saltmarsh vegetation can be utilized in restoration projects that promote pioneer vegetation establishment and biodiversity. Microphytobenthos constitutes an important food resource of shorebirds and macrozoobenthos (Herman et al., 2001; Van der Wal et al., 2008; Mathot et al., 2018).

With global warming, the growth period of the microphytobenthos might be prolonged, which possibly leads to the expansion of biofilms and benefits the ecosystem. However, increasing storm frequency and wave heights might counteract this trend by destruction of the biofilms close to mouth of the estuary (Le Hir et al., 2007). When conditions are created that facilitate microphytobenthos growth, the process of vegetation colonization and expansion can be accelerated, new feeding grounds for endangered species can be created and the erosion induced by sea level rise and storms can be mitigated. For instance, the protection of erosive intertidal areas from waves and currents can help promote growth of biofilms and pioneer vegetation, which will enhance mud settling and accretion.

\subsubsection{Destabilizing eco-engineers}

As opposed to biostabilizers, macrozoobenthic organisms that destabilize the sediment promote erosion and sediment redistribution or even sediment export from estuaries (Chapter 5). In addition to previously observed local mud reduction induced by biodestabilizers (e.g. Widdows and Brinsley, 2002; Volkenborn et al., 2007), this work expands this observation towards the scale of the entire estuary. In the model, the erosion of the mud along the shores reduced the cohesive properties of the banks and promoted sediment transport. Sediment resuspension by biodestabilizers is known to be one potential factor mediating suspended sediment concentrations in muddy estuaries, e.g. in the Ems-Dollart Estuary (Talke and De Swart, 2006), or inhibiting the infilling of Holocene estuaries (De Haas et al., 2018). The capacity of biodestabilizers to promote erosion of the shorelines of estuaries and bays has large-scale implications for the dimensions of the system. Since the eco-engineering effects by the generic biodestabilizers enhanced the exposure of the supratidal areas to higher flow velocities, the estuary expanded laterally and created wider accommodation space. A widening intertidal area with gentle bank slopes evolved and the enhanced sediment export towards the delta resulted in reduced mud content of the estuary. The eco-engineering efficiency of the species therefore determines lateral and vertical expansion, enhances channel dynamics and shoal migration and potentially slows down infilling processes. With regard 
to increasing sea level rise rates and sediment deprivation due to upstream dam construction, the increasing accommodation space induced by macrozoobenthic destabilizers can have strong negative consequences for estuaries to keep up with sea level rise (Leuven et al., 2019; Best, 2019).

The eco-engineering effect of biodestabilizers depends on their habitat preferences and eco-engineering intensity (Chapter 5). Morphology was defined by the key eco-engineer as opposed to the more abundant but less efficient biodestabilizer. With the generic mud shrimp being a strong destabilizer, it promoted the erosion of large parts of the sediment upstream in the model, whereas the generic lugworm, a moderate destabilizer, invoked limited effects on bed level change. But not only the species-specific eco-engineering effect determined morphological change, also the mud in the bed where the species live defined how much material can be eroded (Chapter 5). Naturally, increasing mud content in the bed increases the potential for erosion as more mud is available to the water column. For the evolution of estuaries, this finding suggests that we need to consider both the prevailing species and the characteristics of the sediment. Muddy estuaries (e.g. the Ems-Dollart estuary) might be affected more by eco-engineering than sandy estuaries (e.g. the Western Scheldt estuary). However, sandy systems might be indicators for the presence of biodestabilizers (Volkenborn et al., 2007). More research is therefore needed to elucidate where species presence induces a change in the system state through promoted export of cohesive sediments and where abiotic conditions determine species occurrence (Day et al., 2013).

The effect on the morphology of the estuary depends on the type of biodestabilizer and its habitat preferences (Chapter 5). The model results show that the resuspension by the generic mud shrimp limited its habitat by reducing the mud content of the bed, which lowered abundances and resuspension rates with time. In this case, the evolving abiotic conditions guaranteed habitat of the species while species abundance and expansion were controlled through biotic mediation. This led to a negative eco-engineering effect in terms of species abundance. In contrast, the generic lugworm maintained its habitat through constant moderate resuspension, whereas the inherent abiotic conditions (i.e. mud content of the bed) impaired its expansion, leading to a positive eco-engineering effect. From these contrasting feedbacks we can infer that species-specific traits determine if either abiotic or biotic processes control species expansion. However, more research is needed to disentangle under which conditions, i.e. mud content, hydrodynamic forcing and ecosystem structure, either the abiotic or biotic processes are the dominant driver of species abundance.

These findings illustrate that 1 ) the same functional group induces similar trends but ecoengineering intensity defines how strong the morphological variation, 2) the habitat characteristics control the magnitude of morphological change through the availability of erodible sediment, and 3) the emerging species-specific abundances are controlled by either inherent abiotic conditions or by biotic modification of the habitat.

\subsubsection{Eco-engineering of species communities}

This work illustrates that species communities evolve varying abundances depending on species interactions and habitat modification and, as a result of their net eco-engineering effect, shape local and large-scale morphology (Chapter $3 \& 5$ ). The results in Chapter 3 
showed that mud stabilization by microphytobenthos and enhanced mud settling induced by vegetation lead to a positive feedback between the two: even though mud availability was limited, the two species did not compete for the resource mud and were able to expand their habitat. Chapter 5 illustrated that direct competition between two macrozoobenthic species facilitated the expansion of the competitive species resulting from the eco-engineering of the recessive species. As a result, the recessive eco-engineer modified its habitat, such that it became expelled by the spread of the competitive species. This concept of species succession is similar to the one observed in vegetation, where bed accretion by pioneer vegetation ultimately leads to them being outcompeted by successive and more competitive plant species (Allen, 2000; Townend et al., 2011). Similar as described for saltmarshes (Bertness and Pennings, 2002), a distinct species zonation between competing macrobenthic species evolves. The introduction of microphytobenthos affected this succession by enhancing the local mud content of the bed. This additional effect of a third eco-engineer interfered with the prevailing feedbacks by altering habitat quality and providing food. This resulted in increasingly complex feedbacks that determined the net abundance of the species. Consequently, the model illustrates that habitat modification by multiple eco-engineers affects both ecosystem composition and morphology through multi-dimensional feedbacks.

Due to this complexity, the eco-engineering intensity of all present eco-engineers cannot simply be added up to predict morphological adaptation. This finding was confirmed by flume experiments carried out during the course of this work (not presented here) that measured mud resuspension thresholds in single species and multi-species experiments of four typical macrozoobenthic organisms from the Western Scheldt estuary. Similar to the results from the model, combined resuspension of several organisms was reduced compared to the sum of their individual effects. In nature, competition between species for space and food and trophic interactions require energy and reduce individual species activity (Odum and Barrett, 1971; Day et al., 2013). However, the model results reveal an additional effect impairing species productivity: individual eco-engineering effects can affect the habitat suitability of the co-existing species such that their abundance changes. These indirect feedback alters the net eco-engineering intensity of the species community and, hence, their biogeomorphological effect. Therefore, the community effect needs to be quantified under the consideration of eco-engineering feedbacks to predict the evolution of the estuarine morphology.

\subsubsection{Eco-engineering effects of saltmarsh, microphytobenthos and macrozooben- thos combined in a model}

As discussed above, key eco-engineers affect both morphology and co-existing species abundances through mediation of the physical habitat. For example, the presence of the lugworm was reported to negatively affect saltmarsh growth or locally inhibit saltmarsh establishment (Volkenborn et al., 2007; Van Wesenbeeck et al., 2007). Moreover, locally increasing flow velocities through macrozoobenthic destabilization close to the edge of marshes possibly control vegetation expansion and facilitate local cliff formation (Murray et al., 2002). On the other hand, Townend et al. (2011) suggested that increasing suspended sediments through bioturbation might nourish marshes through lateral sediment transport. Moreover, seed har- 
vesting or seed burial by macrozoobenthos can have negative or positive effects on saltmarsh establishment (e.g. Emmerson, 2000; Zhu et al., 2016a).

This partly contrasting hypotheses show that we still lack a detailed understanding of how vegetation and benthic species interact and how this relates to system-scale morphology. To shed light onto the interactions and eco-engineering effects of saltmarsh, microphytobenthos and macrozoobenthos, I combined these three functional groups in the idealized model of Chapter 5. Similar to the scenarios in Chapter 5, I investigate two scenarios, one with a community including the moderate, sand-prone biodestabilizer AM and one with the effective, mud-prone biodestabilizer CV. The latter is a grazer on microphytobenthos. The results from these runs are presented as maps (Figure 7.1) and complemented by cross-sectional plots at three locations along the estuary, looking at bed elevations and species abundances (Figure 7.2). In order to investigate reach-scale morphological effects, the hypsometric curves and the relation between intertidal area extent and maximum channel depth are presented for the lower, middle, and upper estuary (Figure 7.3).

Compared to the scenarios with saltmarsh only (SM), the estuary in the multi-species runs is covered abundantly by the eco-engineers (Figure 7.1). The scenario with AM (AM-MPB$\mathrm{SM}$ ) shows biodestabilizer abundance in the lower and middle estuary with microphytobenthos on bars or close to channels and abundant vegetation establishment on the higher shores. In the scenario with CV (CV-MPB-SM), biodestabilizers and microphytobenthos co-occur mainly on bars and close to channels inside the estuary while vegetation and CV co-exist higher up the shores. In contrast to the scenario with only saltmarsh (SM), where vegetation covers floodplains close to the main channel and a few tidal bars, the vegetation expands towards the sides when biodestabilizers are present. This species zonation corresponds with patterns described in literature, where saltmarshes are reported to grow at higher intertidal elevations while intertidal benthic organisms occur on lower mudflats and on top of tidal bars (e.g. Widdows and Brinsley, 2002; Widdows et al., 2004; Van der Wal et al., 2008; Daggers et al., 2018). Moreover, co-occurrence of AM and saltmarsh vegetation was reported to be limited (Van Wesenbeeck et al., 2007), whereas CV occupies the channel networks dissecting tidal marshes as described in Hughes (1999). However, in nature some macrozoobenthic species are prey to intertidal waders (Austen et al., 1999), which can reduce their extent towards the saltmarsh edge compared to the model results.

The link between the species distributions and the morphology is illustrated by the three cross-sections (Figure 7.2a1-3 \& b1-3). A partly overlapping species zonation from the edges towards the center of the channels is visible: Vegetation establishes at the highest edges of the cross-section while microphytobenthos and macrozoobenthos spread towards the center towards the channels. Species abundance and morphological effect depend on the locally dominating species: Where vegetation prevails, erosion is limited, whereas benthic organisms induce erosion and lateral redistribution of sediment. Microphytobenthos is partly able to stabilize local morphology.

In terms of saltmarsh growth, a large difference occurs between scenarios with AM and $\mathrm{CV}$ : in the scenario with AM, vegetation and microphytobenthos stabilize and accrete sediment locally. Saltmarsh can grow close to the channels and on the bars in the mouth, where 


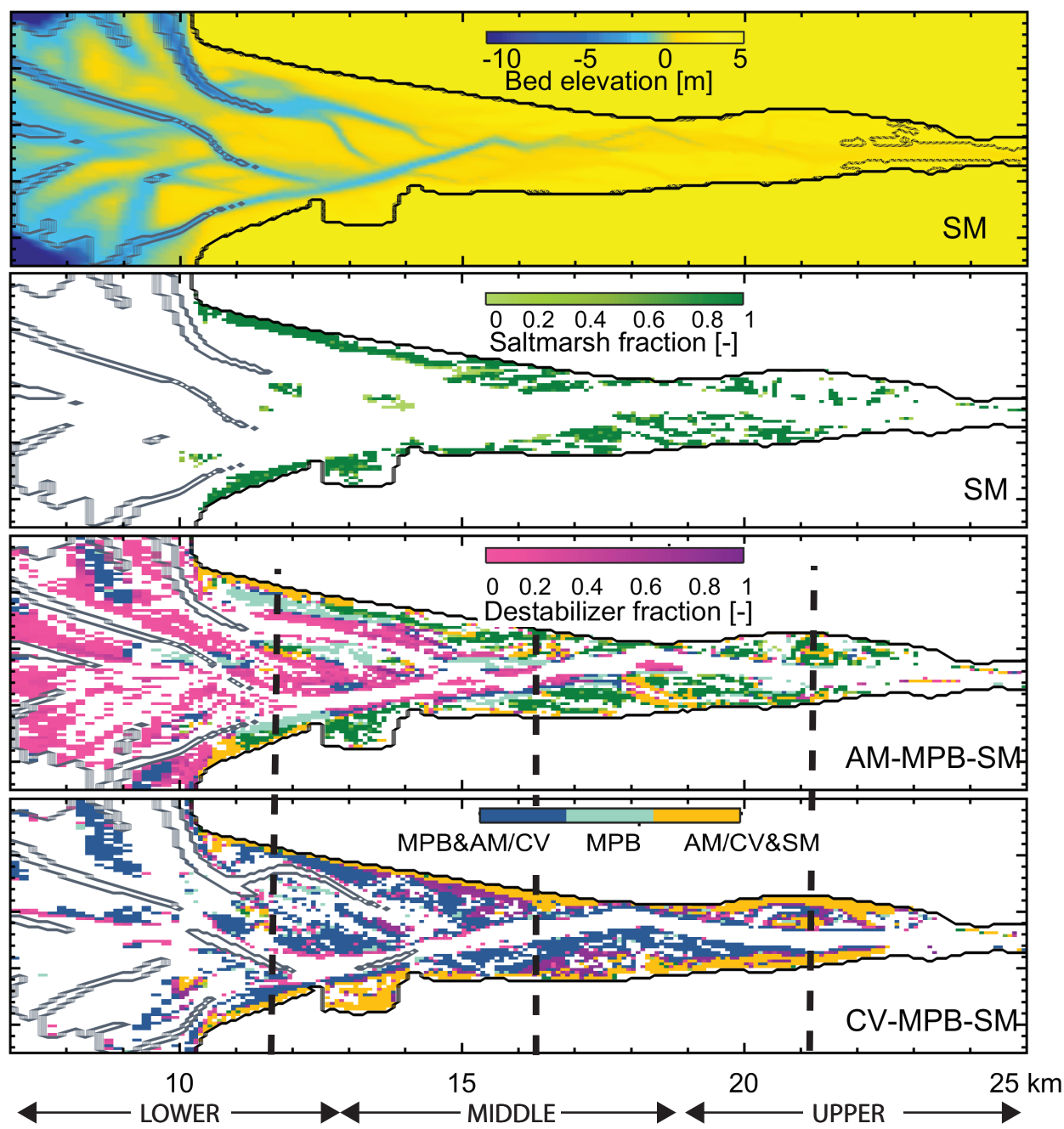

Figure 7.1: Bed elevations and species fractions from the run with saltmarsh vegetation only (SM) and the multispecies runs including macrozoobenthos (AM \& CV), microphytobenthos (MPB) and saltmarsh as maps on estuary outline. Top panel shows bed elevations in the saltmarsh scenario. Lower panels are species abundances on outline of the estuary (black lines) and boundary subtidal-intertidal (gray lines). Colors indicate fractions of saltmarsh (green colorbar) and AM or CV (pink colorbar), MPB presence (light green color), both MPB and AM or CV presence (blue color), and both SM and AM or CV presence (yellow color). Dashed lines indicate locations of three cross-sections. Limits of three reaches analysed in subsequent figures displayed between horizontal arrows. 
it traps suspended sediments. The flow is partly concentrated into the slightly eroding main channels, but overall bed level changes are small. However, in the presence of CV the widening channels impair vegetation establishment close to the channel edges and limit saltmarsh growth to the highest banks. Instead, microphytobenthos occupies the lower elevations close to the channels. As a result, the bank slopes become smoother (b2 \& b3) and sediment is transported downstream.

The two model scenarios show that eco-engineering intensity determines the spatial organization of the ecosystem and controls vegetation establishment. In the lower and middle estuary, the variations in eco-engineering intensity and habitat of AM and CV result in contrasting species composition with vegetation being highly abundant in the first, and benthic organisms in the latter scenario. As a result, vegetation is facilitated in estuaries with limited bioturbator-induced bed level changes, whereas efficient destabilization limits vegetation growth to the sheltered banks and upper estuary. Such behavior has already been reported from marshes in the UK, where resuspension by C. volutator enhanced saltmarsh erosion at the marsh-scale (Hughes, 1999).

With regard to the contrasting hypotheses that bioturbation can have both negative or positive effects on saltmarsh accretion and erosion (Townend et al., 2011; Volkenborn et al., 2007), the results show that the effect on vegetation depends on the eco-engineering intensity of the biodestabilizer. The degree to which they determine whether saltmarshes are nourished or eroded depends on their capacity to resuspend deposited sediments. Similar to seed harvesting, which has been proposed to inhibit vegetation establishment on intertidal flats (e.g. Emmerson, 2000; Zhu et al., 2016a), the species-specific habitat modification can be one reason for inhibited or delayed saltmarsh establishment on bare mudflats.

These insights on the large-scale morphological feedbacks between macrozoobenthic destabilizers and saltmarsh growth enhance our understanding of potential large-scale drivers for eroding saltmarshes and intertidal flats. To mitigate saltmarsh degradation and aid realignment of marshes, the creation of conditions that favor macrozoobenthic communities with positive feedbacks on marsh growth can be beneficial. However, more research is needed to improve our understanding of species-specific eco-engineering effects under various environmental conditions and the redistribution of the resuspended sediment.

The system-scale effect of one or more eco-engineers affects the adaptation of the reachscale morphology. The cumulative bed level distribution differs between reaches (Figure 7.3): while vegetation and microphytobenthos are able to protect the bed in the lower estuary reach, bed elevations lower significantly in the middle and upper estuary. The latter effect leads to an expanding intertidal area and deeper channels (Figure 7.3B). Consequently, biostabilizer growth is impaired by strong sediment resuspension and cannot compensate for bioturbator-induced erosion, especially when $\mathrm{CV}$ is present. In the lower estuary the erosion induced by $\mathrm{CV}$ can be counteracted by biostabilization and downstream sediment transport, leading to a reversed trend by reducing intertidal area extent and promoting shallower channels. These contrasting trends in intertidal area extent and maximum channel depths affect the tidal prism differently. Increasing cross-sectional area in the middle and upper estuary induced by $\mathrm{CV}$ possibly allows the tidal wave to propagate further into the estuary, whereas 

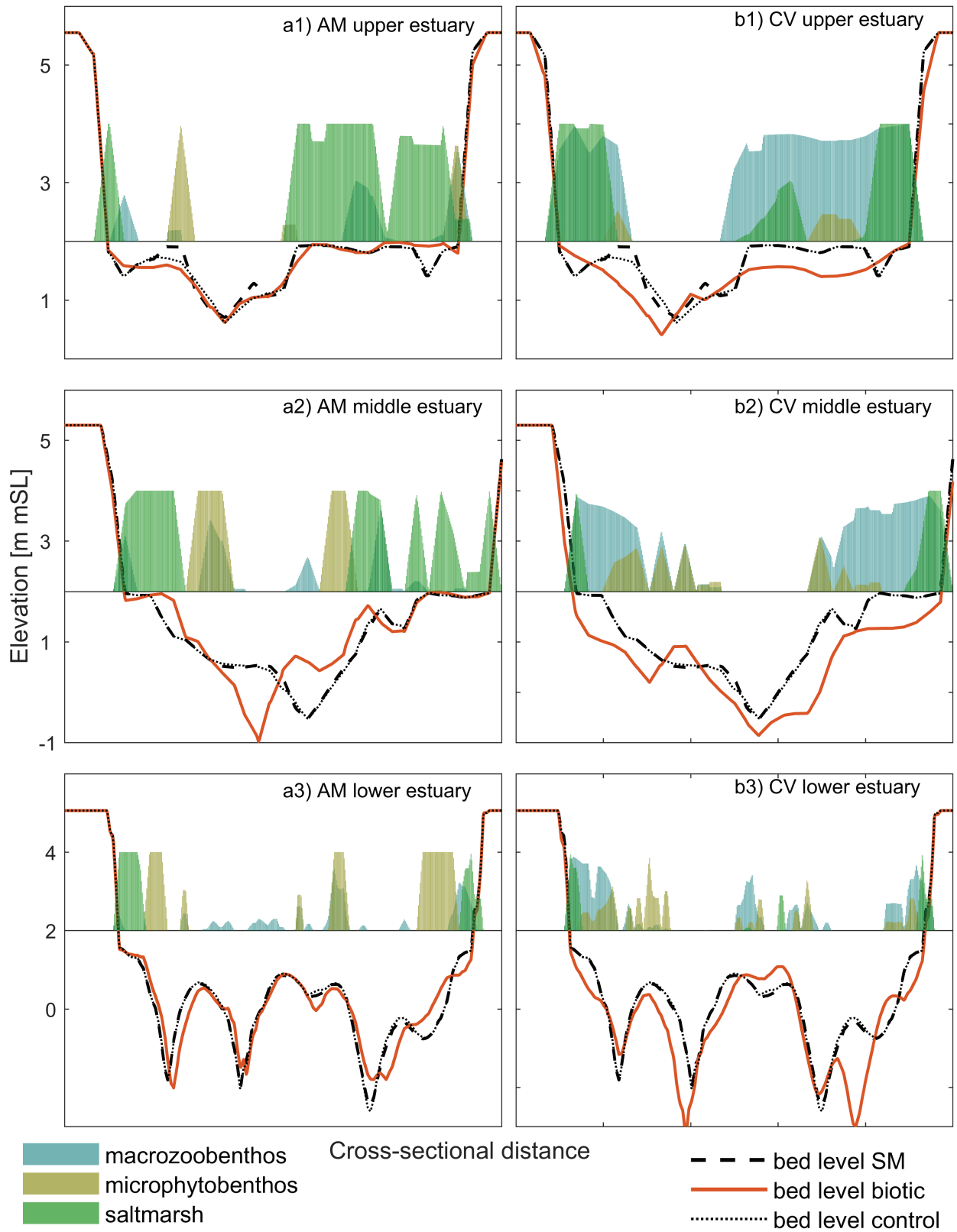

Figure 7.2: Cross-sections along the estuary for AM-MPB-SM (a1-3) and CV-MPB-SM (b1-3) with species as qualitative shades on bed elevations (red line) after 50 years of simulation time compared to the control (dotted line) and the scenario with only saltmarsh (dashed line). Black solid line is high water at $2 \mathrm{~m}$. 

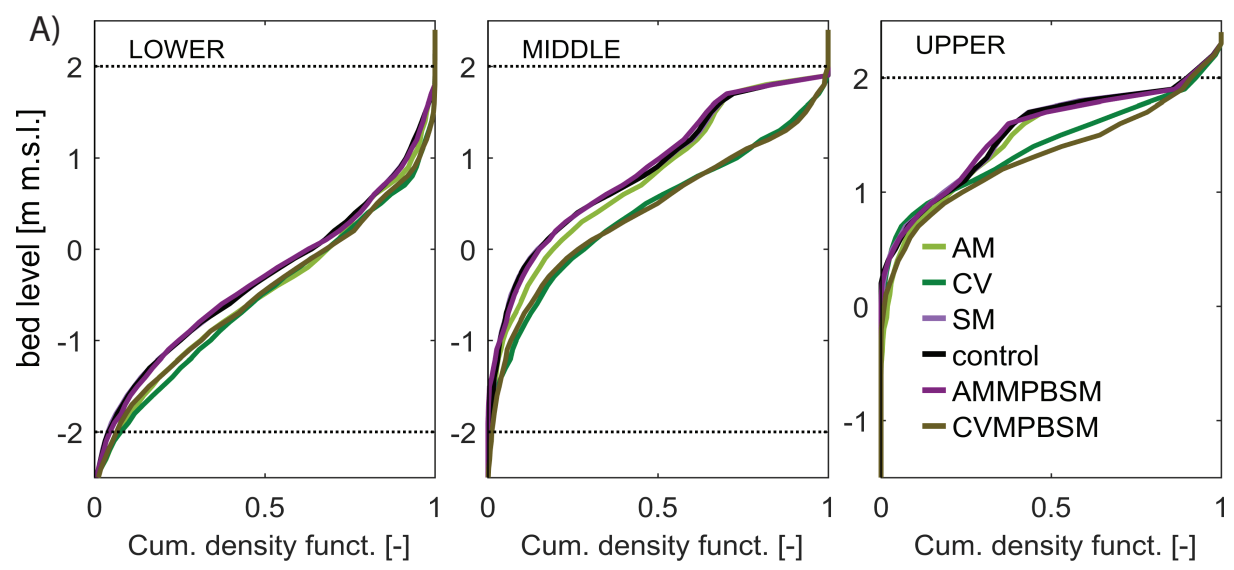

B)
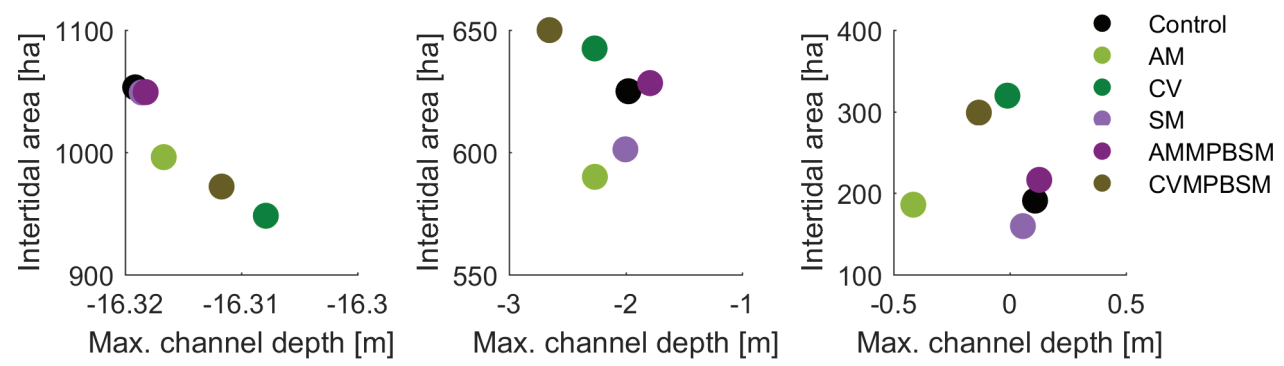

Figure 7.3: A) Cumulative bed level distribution for the three reaches and all scenarios compared to B) intertidal area over maximum channel depth. The dashed lines are high and low water. Colors are the same in both graphs.

the stabilization of the intertidal areas and the channels by vegetation (SM \& AMMPBSM) might enhance mud deposition and reduce the tidal prism (Braat et al., 2019a).

\subsubsection{Application of the results to Holocene and Paleozoic estuaries}

During the Mid-Holocene, many Dutch tidal basins were infilled and closed off when sea level rise decelerated while others remained open. Whether an estuary closes off was hypothesized to depend on tidal asymmetry, sediment availability, mud abundance and biogeomorphological processes (Vos, 2015; De Haas et al., 2018). Especially decreasing accommodation space and constant sediment import are regarded as important prerequisites for infilling. On the other hand, preserved peat in the Dutch coastal plain, with its tidal basins and estuaries, shows that reed and woody vegetation existed in and around these systems, potentially promoting sediment capture and infilling. However, we still lack understanding of how species-specific traits of vegetation and biodestabilizers relate to the infilling process.

The results from this work suggest that specific traits of eco-engineering species likely influenced infilling and closure of Holocene estuaries. Probably, vegetation traits played a ma- 
jor role in the capture of sediments in estuaries during the Holocene, as recently suggested for vegetation density (Boechat Albernaz et al., 2020). Since plant characteristics were shown to determine pioneer vegetation establishment and mud capture at the large scale (Chapter 2 and 3), vegetation establishment of saltmarshes, reeds or woody vegetation possibly contributed to infilling at varying rates. Consequently, more research is required to look at the eco-engineering intensity, specific life-cycles and habitat of the vegetation species that are found in those past estuaries to quantify their contribution to the infilling process.

The model results show that destabilizing macrozoobenthos has the potential to promote large-scale erosion of estuaries and to flush riverine mud through the system towards the sea, whereas microphytobenthos can inhibit erosion (Chapter 5). Potentially, benthic ecoengineers promoted or impaired infilling of Holocene estuaries (De Haas et al., 2018). More research on macrozoobenthic assemblages and diatoms in the stratigraphy can elucidate at what rate estuaries filled in. Possibly, infilling of estuaries depended less on the abiotic drivers than previously thought, but was instead largely mediated by biogeomorphological processes.

Along geological time-scales, the evolution of specific traits of land plants along the Paleozoic (541-252 million years ago) was hypothesized to have facilitated increasing vegetation abundances, promoted mud rock preservation within sediments, and allowed the evolution of new geomorphic features, e.g., meandering or anabranching river channels (e.g. Davies and Gibling, 2010; Gibling and Davies, 2012; McMahon and Davies, 2018). Since a large part of the literature evaluates the potential effects of land plant evolution on riverine morphology, this work provides new insights into the evolution of estuarine landforms (Chapter 6). Results from the eco-morphodynamic model suggest that also Paleozoic estuaries were likely influenced by the effects of the newly evolving land plant traits, such as root development, phenotype complexity and increasing resilience against environmental stresses (Chapter 6). Especially root development enhanced resilience, which led to larger and denser vegetation patches with larger eco-engineering intensity: more mud was retained in the sediment bed, which expanded from only local accretion by primitive plants to system-wide mud accumulation by arborescent vegetation. As in the modern estuaries, the promoted sediment deposition lowered sediment export rates towards the delta and the ocean. The results in Chapter 6 show that the onset of land plant colonization likely affected sedimentary processes and morphological adaptation, which led to the development of muddy, stable floodplains. The emergence of new biogeomorphological processes during the colonization process in the Paleozoic suggests that pre-vegetation sedimentary processes were non-uniformitarian.

The advent of bioturbation by burrowing infauna as preserved in the fossil record (ca. 542 Ma ago) was suggested to have altered morphological processes and ecological and geochemical functioning of aquatic habitats, leading to a dramatic change in the appearance of ocean floors (e.g. Meysman et al., 2006). Although the effects of ancient biodestabilizers were not tested here, the findings in Chapter 5 suggest that also past estuaries have likely been affected by bioturbation. Similar to the mud retention imposed by past land plants, the presence of giant bioturbators as found in the rock record possibly induced sediment reworking and export to the ocean (for instance Arthropleura (e.g. Pearson, 1992)). 
Evolutionary geomorphology suggests that eco-engineering has been driving the evolution of land plant traits and geomorphology through niche development (Steiger and Corenblit, 2012). The results from Chapter 6 support this theory as Paleozoic land plants showed to have likely had significant effects on past morphologies. The biotic modification of the environment led to the development of new, more muddy environments that could have acted as new niches for species to occupy. As a result, the species could have adapted to the new environment through the evolution of new traits. Consequently, eco-engineering effects possibly acted as a driver of both morphological and plant-evolutionary processes. One example could be the development of roots, which facilitated the colonization of dynamic and drier environments ultimately led to the formation of dense forests (Schumm, 1967; Lu et al., 2019). Further research on the abiotic-biotic feedback loop in conjunction with niche formation and evolutionary biology can help disentangle the driving processes in both morphological and species evolution.

\subsection{Interpretations of the results for the response of eco-engineers and mor- phology with regard to global warming and microplastic pollution}

Since the results from this thesis improve our understanding of biogeomorphological processes in estuaries, it is possible to generalize how potential species shifts induced by climate change, microplastic pollution or species invasion might feed back on estuarine morphology. In the following section, I describe possible ecosystem changes induced by climate change and species invasion, present a conceptual model of the responding morphology, and evaluate how microplastic occurrence as a recently identified source of pollution might interact with large-scale biogeomorphological processes.

\subsubsection{Shifts in species abundances and effects on estuarine morphology}

In estuaries, shifts in species abundance and composition can be induced by abrupt or continuous climatic changes or changes in nutrient supply, temperature or suspended sediment load and strongly affect ecological communities (Dippner et al., 2010; Kelly and Goulden, 2008; Lenoir et al., 2008). If species shifts involve important eco-engineers, they will strongly influence the modification of the environment (Thrush et al., 2006; Lohrer et al., 2010; Kristensen et al., 2011). One main driver of species shifts is the rising global temperature. For example, the northward migration of the temperate saltmarsh species Salicornia veneta along the North Adriatic coastlines reduces vegetation densities, affects soil stabilization and tidal channel formation (Strain et al., 2017). This rather sparsely colonizing species outcompetes existing saltmarsh species through its high tolerance to soil salinity. Another example is the transition from saltmarsh- to mangrove-dominated systems at the East coast of the United States that is expected to affect stability and sediment trapping of Floridas coastlines (Cavanaugh et al., 2019). Shifts in macrozoobenthic communities have been observed for several systems all around the world (Dippner et al., 2010; Kristensen et al., 2014; Kröncke et al., 2013) and projected towards the future (Singer et al., 2017). Their changes affect ecosystem functions and services, such as water filtration, food provision, shoreline protection, to name only a few (Lohrer et al., 2004; Kristensen et al., 2014). 
Species shift can also be induced through species invasion or evolution. Invading species can outcompete indigenous species, which will lead to shifts in ecosystem structure and species dominance (Santoro et al., 2012; de la Riva et al., 2019). The introduced clam $R u$ ditapes philippinarum was documented to widely spread in European estuaries and modify their habitat through eco-engineering activity (Humphreys et al., 2015; Soissons et al., 2019). Another prominent example is the spread of Spartina anglica, a hybrid saltmarsh species between a native (S. maritima) and an introduced form (S. alterniflora), from the end of the $19^{\text {th }}$ century onwards (Allen, 2000). This fast-spreading species S. anglica has major consequences for ecosystems of the coasts and estuaries of northwestern Europe (Scholten and Rozema, 1990; Proffitt et al., 2005). Likewise, species invasion was shown to alter biogeomorphic feedbacks and geomorphologic features, such as channel morphology in saltmarshes and rivers (Schwarz et al., 2016; Van Oorschot et al., 2017), suggesting that species shifts will likely affect the large-scale morphological evolution of estuaries.

Species shifts result in contrasting estuarine systems depending on the key engineer that is facilitated or introduced (Hooper et al., 2005). For example, the sensitivity of benthic species to inter-annual temperature variations will amplify with global warming and possibly induces a shift from bioturbator- to biostabilizer-dominated systems (Widdows and Brinsley, 2002) (Figure 7.4A). From the results in Chapter 5 we can infer that increasing stabilization of mudflats will reduce sediment transport and export towards the sea. This can lead to enhanced sediment accretion in the upper estuary, reinforced by expanding biofilms that stabilize mudflats. Increasing mud deposits will fill up accommodation space and reduces the tidal prism (Braat et al., 2019b). The increasing mud cover and related bed elevations can promote new saltmarshes to establish (Chapter 3). On the other hand, marshes and riparian vegetation previously nourished by macrozoobenthic resuspension might disappear (Townend et al., 2011). This in turn will affect slope margin erosion and sediment transport towards other areas in the estuary (Murray et al., 2002). As a consequence, a large-scale adaptation of estuarine morphology will result in a sediment retaining, more concise, stable estuary with mudflats and saltmarshes at the fringes and on the bars where microphytobenthos can withstand waves and tidal currents. Enhanced mud deposition might reduce water turbidity, which can facilitate primary production, provide food and spawning habitat for fish in sheltered subtidal areas and breeding areas for birds within extensive wetlands. Light penetration towards the subtidal possibly facilitates establishment of sea grasses. Moreover, the evolving stable main channels facilitate recreation, fishing and shipping.

Shifts towards sparser vegetation species (see Chapter 4) or increasing grazing activity by macrozoobenthos on stabilizing biofilms (Widdows et al., 1998b), on the other hand, could result in opposite effects (Figure 7.4B): erosion of the higher elevations will create extensive sand- and mudflats in the intertidal that can be inhabited by macrozoobenthos. Gentler slopes will provide more accommodation space for the tides with larger propagation length due to reduced vegetation roughness. As a result, the tidal wave can travel further upstream, eroding channel banks and promoting widening of the system. This can negatively affect flood safety for adjacent cities and human settlements (Townend and Pethick, 2002). Moreover, the loss of saltmarshes will lead to enhanced carbon release to the atmosphere (Mudd et al., 2009). Reduced vegetation cover and enhanced macrozoobenthic habitat can create 
A) Stable, concise morphology dominated by biostabilizers

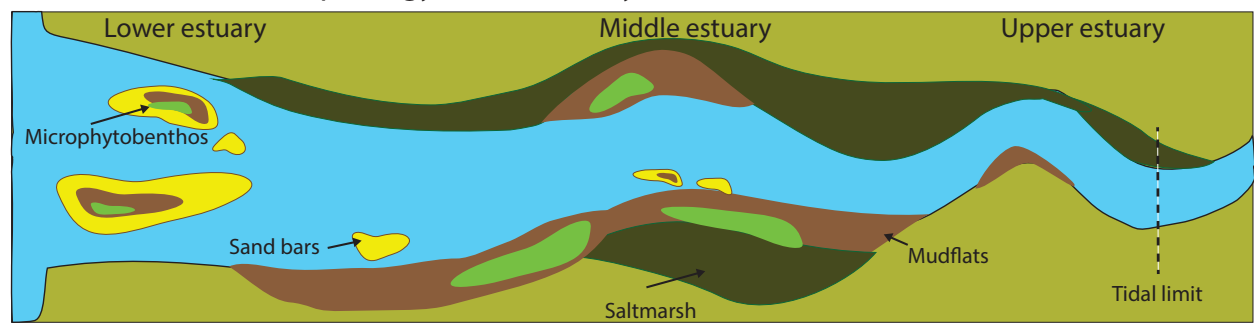

B) Dynamic, widening morphology dominated by biodestabilizers

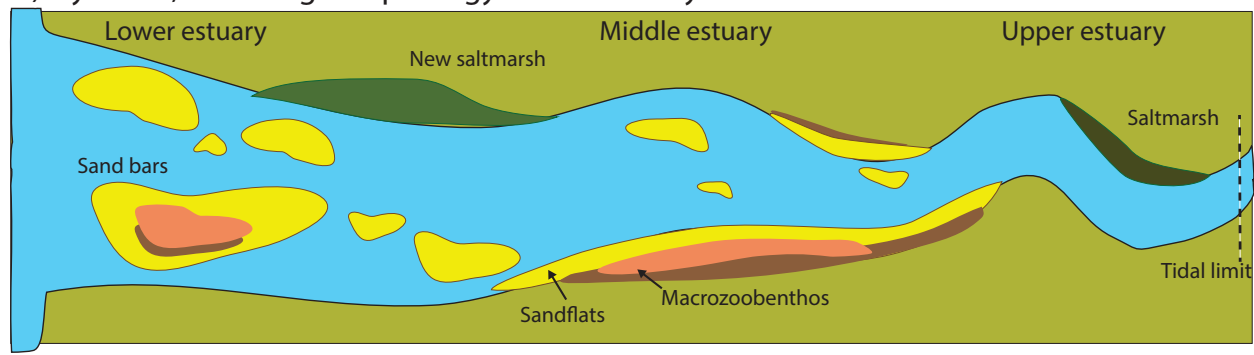

Figure 7.4: Conceptual estuary dominated by biostabilization (A) or biodestabilization (B). (A) represents a depositional system characterized by extensive saltmarshes and mudflats, which confine estuarine morphology. In contrast, (B) is erosional, leading to lateral erosion, saltmarsh degradation and redistribution of sediment. Mud content decreases but upstream erosion promotes tidal bar formation in the mouth.

an erosional system that exports sediment and provides extensive gently-sloped intertidal habitat. Increasing intertidal area will provide abundant habitat for many species through the creation of a heterogeneous environment that allows for niche establishment and colonization by rare species (Corenblit et al., 2011; Obst et al., 2018). However, reduced mud content and large tidal currents can result in dynamic channel-bar patterns that inhibit the formation of extensive mudflats or saltmarshes.

A warming climate will also directly affect estuaries through ocean acidification or enhanced storm frequencies, sea level rise rates, and rainfall events (Leonardi et al., 2018; FitzGerald and Hughes, 2019). These external drivers have strong ecological implications by enhancing hydrodynamic stresses and affecting suspended sediment import towards estuaries and marshes. Increasing sea levels can be mediated under sufficient sediment supply, especially when wetlands are present (Mudd et al., 2009; Schuerch et al., 2018; FitzGerald and Hughes, 2019). However, if sediment supply is limited or sea walls constrict species migration, marshes will die-off and the estuary either progresses upstream or drowns (Hughes, 2004; Xie et al., 2020). This effect is possibly enhanced in biodestabilizer-dominated estuaries where erosion predominates.

The model results in section 5.5 show that, if sea level rise rates are low, the species propagate upstream where they enhance the erodibility of the sediment. High rates of sea level 
rise, however, exceed the adaptation time of the ecosystem and can induce a shift in macrozoobenthic organisms: the adapting abiotic conditions of the estuary lead to the disappearance of mud-prone species, whereas sand-prone organisms can expand their habitat. Similar to trends observed in marshes (e.g. Kirwan and Megonigal, 2013), high sea level rise rates can cause benthic species to disappear from the estuary. The altered eco-engineering effect has consequences for the local morphology, where the newly abundant sand-prone bioturbator can cause erosion of the lower intertidal that constitutes its habitat (Section 5.5). Moreover, this will reduce bed level changes since the sand-prone bioturbator causes moderate erosion of the sediment (Section 7.1.4). Since sediment supply is crucial for the survival of marshes under sea level rise (Kirwan et al., 2016) the shift from erosion in the higher to the lower intertidal will affect adjacent tidal marshes. When considering future wetland resilience or nature-based flood protection under increasing sea level rise rates (e.g. Temmerman and Kirwan, 2015; Feagin et al., 2015; FitzGerald and Hughes, 2019), these destabilizing effects can play an important role in the success of vegetation establishment and wetland accretion.

\subsubsection{Species shifts can be mitigated through the promotion of biodiversity}

One way to mitigate initiated or future species shifts and morphological changes in estuaries is to promote biodiversity. Studies have shown that the resilience of an ecosystem to disturbances increases with increasing biodiversity (Corenblit et al., 2007; Obst et al., 2018). If a range of species responds differently to various environmental perturbations, they help stabilize the ecosystem, for example against the impacts of sea level rise (D’Alpaos et al., 2012). Likewise, the probability of a successful species invasion is reduced with increasing species complexity (Hooper et al., 2005). The establishment and growth of a variety of species is promoted through the availability of heterogeneous habitat, which can be created by ecoengineering. Therefore, we can improve biodiversity through protection of vulnerable ecoengineering species from direct physical disturbances, but also by stimulating the growth and survival of 'morphologically valuable' or rare eco-engineers (Corenblit et al., 2011; Obst et al., 2018). To do so, we need to acquire a better understanding of life-cycles, population dynamics and traits of the species that are especially threatened by disturbances. The presence of a variety of eco-engineers will lead to a more resilient and diverse system that provides a multitude of ecosystem functions and services. As a result, if we succeed in the protection of these eco-engineers in estuaries, we can guarantee heterogeneity of habitat and the prosperity of a variety of species that sustainably mediate the effect of external or internal disturbances.

\subsubsection{Implications of the findings for habitat quality, pollution and microplastic dis- tribution in estuaries}

The hydro-morphodynamic processes in estuaries determine the accumulation and transport of pollutants. Pollution can reduce the productivity and metabolism of species or can even be lethal when in too high concentrations (e.g. Hale et al., 2018). Especially in recent years, the deposition of microplastics (plastics with a diameter of several millimeters or smaller) was identified as a key parameter in soil contamination, posing a threat to marine life and human health (do Sul and Costa, 2014). Many studies investigate how the ingestion of microplastics by marine organisms can lead to reduced species productivity and increased 
mortality (e.g. Kane and Clare, 2019; Hope et al., 2020). Estuaries are suspected to be one of the key sinks of microplastics owing to the river input that transports pollutants from upstream sources, such as industrial and urban sites, into the estuary and the decreasing flow velocities with increasing estuary width that promote settling (Corcoran, 2015). Recent studies showed that accumulation of microplastics can be attributed to source terms and sedimentary properties such as mud content and grain size (e.g. Enders et al., 2019) suggesting that largest microplastic deposition occurs close to rivers and in the sheltered intertidal sediments.

Chapter 5 showed that benthic organisms can alter the resuspension and deposition of mud and therefore probably also affect resuspension of microplastics. While the sedimentary and morphological characteristics of the coast are thought to be important for the storage and flushing of microplastics from coastlines towards the ocean (Kane and Clare, 2019), the role of biotic mediation in this process is still unknown. Associated with biotic sediment stabilization or resuspension, eco-engineering potentially plays an essential role in the preservation of sediment-microplastic mixtures, altering microplastic resident times and storage in estuarine sediments. Here, I present an example of a basic estimation of microplastic occurrence to illustrate the above idea (Figure 7.5). The figure shows a simplified relation between mud content and microplastic occurrence (derived from Enders et al. (2019)) for the scenarios in Chapter 5. The relative occurrence of microplastics identifies hotspots of microplastic accumulation where 1 is the maximum microplastic abundance linked with a mud fractions of 1 . Since the mud fraction is strongly reduced under bioturbation, the presence of AM and $\mathrm{CV}$ reduces the microplastic storage in estuaries compared to microplastic accumulation induced by microphytobenthos (MPB). The combination of several species stabilizes sedimentmicroplastic mixtures compared to CV. Hotspots are found mainly along the shorelines and floodplains where the largest mud content occurs. Negative effects of microplastic ingestion on species activity are neglected.

The simple approximation of the capacity of eco-engineers to mediate microplastic occurrence in estuaries demonstrates the necessity to incorporate biotic effects in future studies on microplastic accumulation in marine sediments. However, not only the effect of ecoengineering on microplastic abundance is important, but the feedback loop on species activity needs to be made. Since habitat degradation by microplastics is an increasing threat inducing biodiversity loss and species shifts, we need to understand these feedbacks to predict the development of the adapting morphology.

\subsection{A step forward in parameterizing eco-engineering effects in hydromor- phodynamic models}

The eco-morphodynamic model developed in this thesis is a novel step towards the combination of dynamic species abundance, growth, and eco-engineering effects with hydromorphodynamic computations. For the first time, various interacting eco-engineers were parametrized based on their individual life-cycles, eco-engineering intensity, and habitat requirements. Advancing from more simplified models that prescribe species growth at specific water level benchmarks or calibrate species occurrence to a specific tidal system 


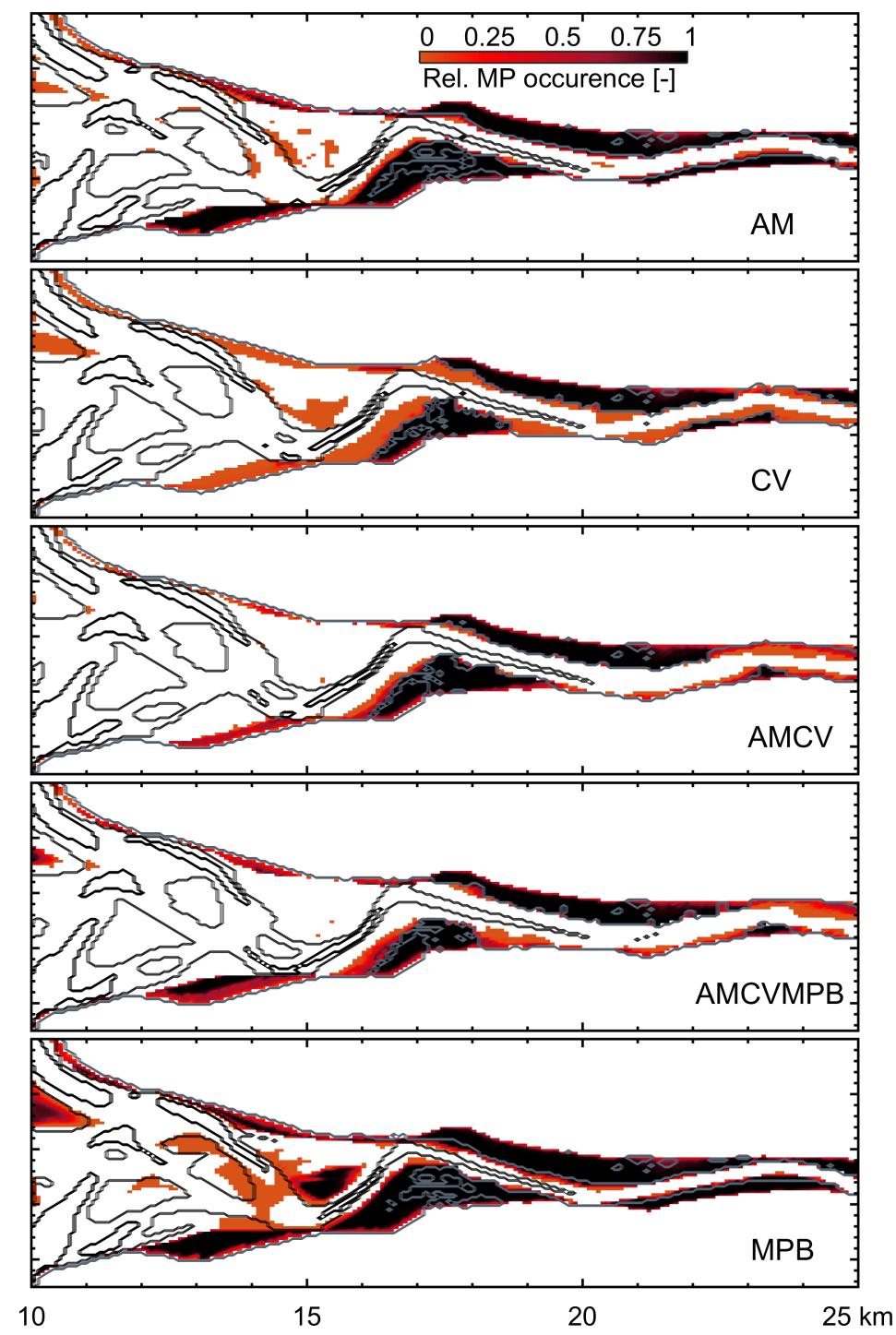

Figure 7.5: Estimation of microplastic occurrence in the scenarios of Chapter 5 based on a linear relation between microplastic occurrence and mud fraction (Enders et al., 2019) shows largest microplastic occurrence close to the river and the banks. In comparison with a control run (REF), biodestabilizers reduce microplastic occurrence and biostabilizers increase microplastic occurrence. The results exclude negative effects of microplastic ingestion on species activity. 
(e.g. Le Hir et al., 2007; Borsje et al., 2009; Fagherazzi et al., 2012), the presented model framework could reproduce patterns observed in nature without calibration, evolving solely from literature-based establishment, growth and mortality relations, species interactions, eco-engineering effects and hydro-morphodynamic processes. After discussing the effects of the eco-engineers on morphology and species growth, I now dive into a more detailed evaluation of the novel modeling framework. In particular, I will explore how the parametrizations in the model improve our understanding of the processes that govern species variations and their morphological effects, model limitations and what questions need to be investigated in future research.

\subsubsection{Generic species parametrizations bridge multiple scales in eco-morphodynamic models}

The sophisticated eco-morphodynamic model showed that species community effects can be investigated by combining abundances and effects of several species in one generic species. The results of Chapter 2, 3 and 5 show that the concept of the functional groups of ecoengineers is a valid simplification to include ecological complexity in large-scale hydro-morphodynamic computations that predict general morphological trends. The combination of a few environmental parameters derived from the literature, namely inundation period, flow velocity, and erosion and deposition or mud content of the bed, suffice to predict generic species pattern in dynamic estuaries (Chapter 2 and 5). The omission of the salinity as a parameter determining longitudinal zonation is a shortcoming with regard to the transition from marine to brackish species, which are characterized by different life-cycles and ecoengineering intensities (Ysebaert et al., 2003; Higinbotham et al., 2004). However, for the scope of this work, namely investigating general trends of large-scale estuarine evolution under contrasting eco-engineering effects, the implemented functional groups are useful to understand morphological evolution while keeping model complexity low (Hooper et al., 2005).

The results describe general trends in the morphological evolution of tide-dominated estuaries, neglecting waves, storm surges and flood events that can lead to enhanced sediment transport into the estuary, can cause erosion of intertidal flats or the reorganization of macrozoobenthic assemblages (Nichols, 1977; Robinson et al., 2003; Bouma et al., 2016; Leonardi et al., 2018; Smith et al., 2019). Wave action might enhance sediment resuspension at the mouth of the estuary and locally reduce mud deposits (Braat et al., 2017), which will affect habitat for macrozoobenthic species and the potential of saltmarshes to accrete sediment. Although large storms are expected to have limited effects on saltmarsh destruction, moderate storm events can lead to a constant erosion of coastal marshes (Leonardi et al., 2016; Mariotti and Canestrelli, 2017), possibly reducing saltmarsh extent close to the sea. The exclusion of large storm events and wave action in the model possibly under-predicts the dynamics at the estuary mouth, but the model reveals novel large-scale morphological trends under eco-engineering activity that provide new insights in our understanding of tide-dominated estuarine morphodynamics.

Where species co-exist, rules need to be established that describe inter-species relations to determine the dominating or mean effect on the environment. These relations can be highly 
simplified as presence-absence or linear relations as in Chapter 5, but they open up a pathway towards a new generation of models that can potentially add an unlimited number of functional groups to eco-morphodynamic models. However, the representation of a multitude of eco-engineers might be more important in ecological studies that predict dominating species and species shifts based on species interactions and eco-engineering effects (e.g. Reijers et al., 2019). In biogeomorphological studies, the study of the most effective eco-engineers can disentangle and quantify biogeomorphological feedbacks and predict morphological evolution (Chapter 5). The herein presented results show that a representation by functional groups is useful to not only predict morphological responses of the estuary but also the effects of species shifts under changing external drivers, e.g. global warming or sea level rise.

The presented modeling framework is able to represent system-scale morphological trends induced by species specific growth but is limited by omitting small-scale processes, such as vegetation-induced turbulence or roughness elements created by bioturbators (e.g. Cheng, 2011; Tinoco et al., 2015). Similarly, small-scale heterogeneities and features with sizes below the minimum grid size are not represented in the large-scale morphological models. Since this work investigates patterns at a large scale, larger grid cell sizes are feasible as smallscale biogeomorphological features can be averaged. Downscaling approaches that capture small-scale variations in flow around plant patches or interactions with groundwater processes (Chen et al., 2020; Gourgue et al., 2020) are useful when looking at morphological adaptations induced by species-specific colonization and expansion pattern at the patch- to marsh-scale (Schwarz et al., 2015b). I expect that for research questions concerning systemwide adaptations of the morphology under prevailing eco-engineers, small-scale morphological variations probably show limited effects. However, since species-specific behavior affects marsh-scale hydro-morphological processes (Chapter 4), more research on the feedbacks between the patch- to intertidal flat- to the system-scale is necessary to elucidate where small-scale processes are limited to effects on local morphology and where they provoke a morphological response at the larger scale. This includes the testing of species parameters that are not accounted for in the parametrized equations, such as stem flexibility, leaf area index or roughness effects through macrozoobenthic structures.

In addition, the model requires adequate hydro-morphodynamic predictions providing realistic values of inundation, velocity and bed level change as those determine species establishment and survival. One prominent example is the choice of an accurate grid cell size of the numerical domain. Chapter 2 showed that grid cell size determines the magnitude of the hydro-morphodynamic parameters in each cell: for larger grid cell sizes, inundation period can be overestimated, which results in larger vegetation mortality. This is related to the difficulty to predict intertidal wetting and drying with the shallow-water equations, which is a shortcoming that could benefit from further research.

\subsubsection{New perspectives in biogeomorphological modeling and future recommenda- tions}

The model constitutes a powerful tool not only to investigate current effects of eco-engineers on morphological evolution but especially with regard to responses to external disturbances in the past and in the future (see Section 7.2). Eco-morphodynamic models that are literature- 
based and include ecological rules and eco-engineering effects hold the necessary flexibility to predict species abundances, zonations and migration that evolve from the included parameter space. By allowing the model to predict its own species distributions, we are able to investigate ecosystem response to external pressures, such as sea level rise, as well as disturbances of the ecosystem structure, such as species invasion. The analyses presented in Section 5.5 provide an example of such a change in boundary conditions, where the combination of sea level rise and eco-engineering of two macrozoobenthic species induces species migration and indicates a shift in species. These insights and the evaluations in this synthesis chapter are just a few examples of the variety of questions that can be answered by the presented modeling framework. Management and policy-makers can benefit from this new generation of models by predicting species response to projected future changes in external drivers.

Future disturbances imposed by climate change, for instance increasing sea level rise rates, wave heights or flood frequencies, pose a multitude of threats to ecosystems, estuarine functioning and usage, and flood safety that require more research to properly manage our changing estuaries. In addition, the accumulation of pollutants in the environment and in the food chain, such as microplastics, degrade habitats and affect species productivity. We can use the herein presented modeling framework to study the evolution of estuaries under different projected scenarios of boundary conditions, which will provide new insights on how ecosystems and morphologies respond. In addition, ecosystem composition and eco-engineer succession, for example through shifts in species dominance, through decline in key engineer abundance or species invasion, are possible consequences that we need to study in more detail to predict and mitigate ecosystem preservation and function. By improving our understanding of the inter-depending processes between ecology and geomorphology, the new modeling framework can contribute to developing mitigation measures of increasing flood risk and biodiversity loss. This will benefit our efforts to guarantee species conservation and sustainable usage of estuaries.

In addition to generic species effects on estuarine morphology, specific eco-engineering species can be modeled by extending the habitat parameter space (similar as in Chapter 4). For example, changing salinity distribution as a driver in species abundance from upstream the estuary towards the sea can induce species migration. Especially with regard to upstream dam construction, climate change or increasing rainfall events that affect salinity concentrations (Nichols, 1977), salinity can be used as a parameter to investigate effects of and on longitudinal species zonation. Moreover, increasing sea levels can cause intrusion of sea water into previously brackish environments (Day et al., 2013). By adding the salinity gradient to the set of habitat parameters in the model, the species response to discharge changes and accompanied morphological adaptations present interesting future prospects.

Moreover, the novel model presented in this thesis allows the study of various species communities and their eco-engineering effects on large-scale morphodynamic systems worldwide. This work is mainly concerned with generic saltmarsh vegetation, biofilms and macrozoobenthic destabilizers and grazers that are characteristic for temperate, dynamic estuaries in northwestern Europe. Distinctions need to be made between the models presented in this work and systems with strongly differing abiotic conditions, such large mud contents, mi- 
crotidal or wave-dominated estuaries. For example, estuaries that are less dynamic are often inhabited by different species communities that include sea grasses, subtidal algal mats or macrozoobenthic communities dominated by deposit-feeders (Day et al., 2013). Similarly, ecosystems towards the arctic or tropics are characterized by different species and coverages. While the herein presented model provides a valuable understanding of biogeomorphological processes in temperate estuaries there remains a large potential to understand and disentangle system-specific processes in various types of estuaries, deltas, tidal basins, rivers and coasts all around the world. Their characteristic species communities, comprising among others riparian vegetation, saltmarshes, mangroves, sea grasses and diverse benthic communities, evolve from the abiotic and biotic characteristics of the system and feed back onto the morphodynamics. We need to disentangle the main parameters that determine specific species occurrence in various systems around the world and how they feed back onto its dynamics. We can elucidate under which conditions species occurrence control the abiotic conditions or, vice versa, where species are determined by the environmental conditions. Based on this new knowledge we can estimate how imposed threats by temperature rise and related species shifts may determine the future evolution of different coastal systems.

\subsection{Conclusions from this work}

The findings from this work improve our understanding of the feedbacks between functional groups of eco-engineers and morphological evolution of past, present and future estuaries. Estuarine morphologies are greatly affected by the presence of eco-engineers: Saltmarsh and microphytobenthos enhance seasonal and longterm mud sedimentation and stabilize largescale morphology while bioturbators promote lateral erosion of the estuary. Hereby, the ecoengineering mechanism and intensity as well as the habitat conditions determine the degree to which the morphology changes. Eco-engineering is also a crucial process in determining species abundances of species communities by creating or degrading habitat of co-existing species. Moreover, the results suggest that the morphological processes in Paleozoic estuaries have been affected by the evolution of land plant traits, implying that the Earth's ancient estuarine landscapes were heavily modified with the greening of the continents. The findings from this work further demonstrate that sea level rise rates trigger species-specific responses that can induce species shifts, with consequences for the morphological adaptation of estuaries. Species shifts and biodiversity change linked with a warming climate and increasing habitat degradation through pollution by microplastics are one of the future challenges for the prediction of estuarine evolution. Below, I answer the previously posed research questions one by one:

1. How well can we predict saltmarsh establishment from literature-based rules for establishment, growth, and mortality, and how important are eco-engineering effects for the saltmarsh pattern?

The eco-morphodynamic model predicts species establishment and pattern well, merely through literature-based species parametrization and without prior calibration. Both at the bar- and the estuary-scale, saltmarsh establishment and extent depend on the species' eco- 
engineering effects that alter flow velocity and inundation period. Density gradients across the marsh are determined by vegetation aging that leads to larger plant sizes and increasing resilience to hydro-morphodynamic stresses.

2. How do saltmarsh and microphytobenthos growth affect mud layer thickness in large-scale estuarine morphologies, and does mud or vegetation occur first?

At the bar-scale, establishment traits of saltmarsh species determine mud layer thickness and extent, which affects the expansion of the marsh through a geomorphological window of opportunity. Microphytobenthos promotes longterm mud deposition on an intertidal flat. A mutual facilitation between saltmarsh and microphytobenthos through eco-engineering effects enhances mud cover and species expansion. Moreover, mud settles on bare flats under calm conditions, whereas species growth promotes mud settling in hydrodynamically active areas through alteration of the ratio between flow velocity and inundation period where conditions otherwise inhibit mud sedimentation. At the estuary-scale, species-specific saltmarsh patterns affects mud layer formation, such that mud thickness is enhanced by a fast expanding species and mud extent by a slowly expanding species.

3. How do saltmarsh species assemblages and associated life-history traits determine tidal channel emergence and what is the effect of species shifts on tidal channel morphology?

Saltmarsh species and their life-history traits determine tidal channel pattern and geometry at the marsh-scale, which determines drainage capacity of the marsh, levee formation and net sediment import or export from the marsh. Temperature-induced species shifts can lead to enhanced erosion of tidal channels, which will increase their drainage and reduce resilience of marshes in the face of climate change. Hence, saltmarsh species determine marshscale morphology and residual sediment transport rates.

4. How do generic macrozoobenthic biodestabilizers, microphytobenthos and their combination affect large-scale estuarine mud distribution and morphology and how is their distribution affected by sea level rise?

Biodestabilizers promote the large-scale erosion of the higher intertidal and supratidal areas of an estuary, which promotes lateral widening of the morphology. The magnitude of this effect is species-dependent, determined by their eco-engineering intensity and the characteristics of their habitat. As a result, effective eco-engineers dominate the morphological evolution of estuaries as opposed to the most abundant species. Microphytobenthos stabilizes intertidal sediments, enhances mud content of the bed and reduces sediment export towards the sea. Species communities of several stabilizing and destabilizing eco-engineers results in differentiated species abundances: The individual eco-engineering effects feed back onto the co-existing species through habitat alteration, affect their abundances and reduce the net eco-engineering effect on the estuarine morphology. Sea level rise induces upstream species migration and a decline in species abundance of a species that thrives in muddy sediment while favoring the expansion of a species occupying sandy habitat. 
5. To what extent were evolutionary stages of land plants able to eco-engineer Paleozoic estuaries and determine estuarine mud content and morphology?

Estuaries in the Paleozoic were likely affected by the eco-engineering effects of land plants, even though the vegetation can be considered more primitive than current species. From the model we can infer that eco-engineering intensity and effect in past estuaries increased along with the evolution of land plant traits that facilitated larger vegetation abundances. As a result, the increasing resilience of the plants, induced by root development and larger and more complex phenotypes, enhanced mud preservation, channel incision and stabilized the channel-bar patterns. With the development of arborescent vegetation the potential for a system-wide preservation of mud in estuaries evolved.

\section{How will species shifts towards biostabilizer-or biodestabilizer-dominated systems affect the} morphological development of estuaries?

The feedbacks between eco-engineers, species interactions and abiotic environment is substantial for the evolution of estuarine morphology. Estuaries dominated by biostabilizers evolve depositional, stable morphologies that retain mud and can facilitate infilling or mitigate drowning under sea level rise. Depending on the eco-engineering intensity of the biodestabilizers, their reworking promotes lateral erosion of channels, prevents establishment of vegetation and leads to sediment export from the estuary. As a result, predicted shifts in biodiversity through climate change, species invasion or pollution have the potential to significantly alter the hydromorphology of temperate estuaries, which in turn feeds back onto carbon storage and abundance of pollutants. We can mitigate the impacts of species shifts by strengthening eco-engineering abundance and biodiversity. 
$-1$

| | 
$-1$

| | 


\section{Appendix A}

\section{Supplementary material for Chapter 2}

\section{A.1 Additional analysis}

The two figures provided in the supporting information display both the theoretical and resulting effect of vegetation on flow parameters, respectively. We first show how the net bed roughness $\mathrm{C}$ and the drag term that are applied in the hydro-morphodynamic computations change with vegetation height and density (Figure A.1). The values were computed using the equations 2.2 and 2.3. Figure A.2 provides the change in resulting computed residual flow velocity in vegetated cells by the quotient between vegetation and reference scenario. Hereby, we calculated the residual mean flow velocity over one tidal cycle for each cell with vegetation in the V2000-scenario and extracted the mean vegetation cover. Subsequently, we calculated the residual mean flow velocity for the same cells in the R2000-scenario and divided each cell. Consequently, the ratio between the two captures the effect of vegetation cover on local flow velocity.

Figure A.1 shows how the net bed roughness $C$ and the drag term " $\lambda$ change with vegetation height. The panels display the development for two characteristic water depth (submerged and emerged) three vegetation densities (colors). It is visible that the net bed roughness and the drag term increase along vegetation height until the vegetation is emerged. For emerged vegetation both values become constant for the value of the real bed roughness $C_{b}=25\left[m^{1 / 2} / s\right]$.

Figure A.2 represents the results of the ratio of the residual mean velocity between the V2000 and R2000 scenarios for all colonized cells along vegetation cover. It is visible that the reduction in velocity strongly depends on the vegetation fraction with most cells lying below a value of 1 (dashed line). 
submerged
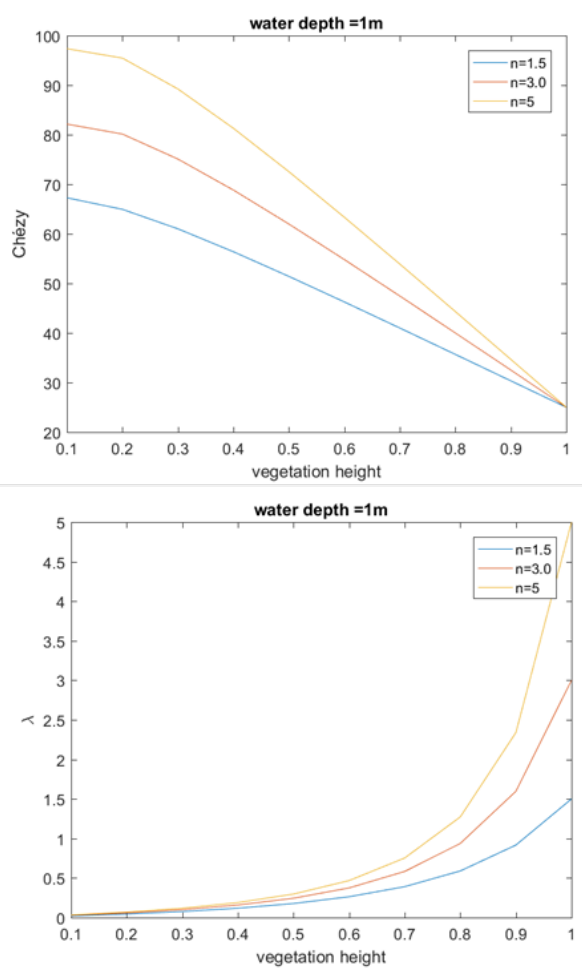

emerged
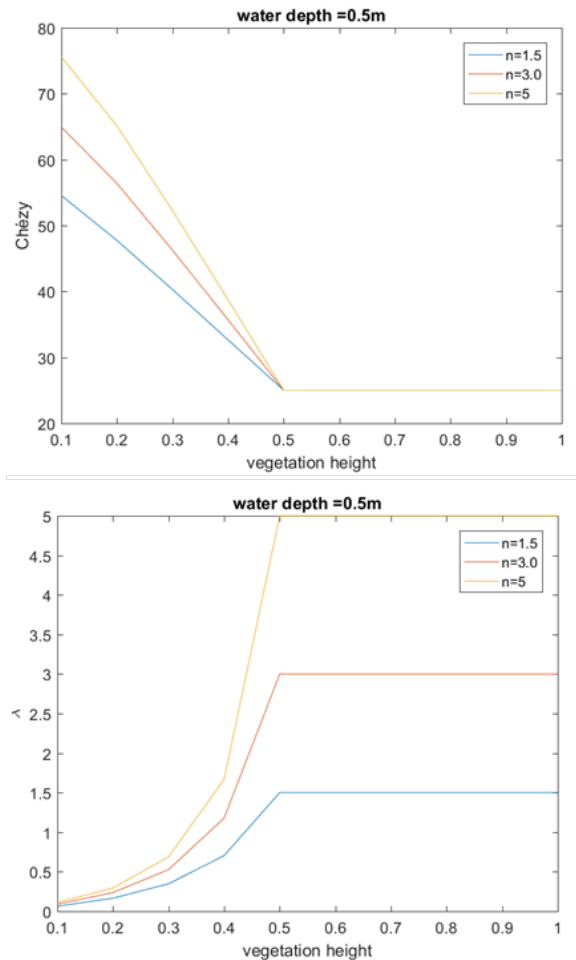

Figure A.1: Variation in net roughness $C\left[\mathrm{~m}^{1 / 2} / \mathrm{s}\right]$ ( $\mathrm{a}$ and $\mathrm{b}$ ) and vegetative drag " $\lambda[1 / \mathrm{m}]$ (c and d) along vegetation height for two water depth (emerged $=0.5 \mathrm{~m}$ and submerged $=1 \mathrm{~m}$ ) (equation 2 and 3 ). The colors indicate three representative vegetation densities $n[1 / \mathrm{m}]$ from the model. When vegetation is submerged, $C$ decreases and " $\lambda$ increases for small vegetation heights until vegetation height equals water depth. When vegetation emerges, net roughness equals bed roughness $C_{b}\left[m^{1 / 2} / s\right]$, which leads to a constant " $\lambda$. 


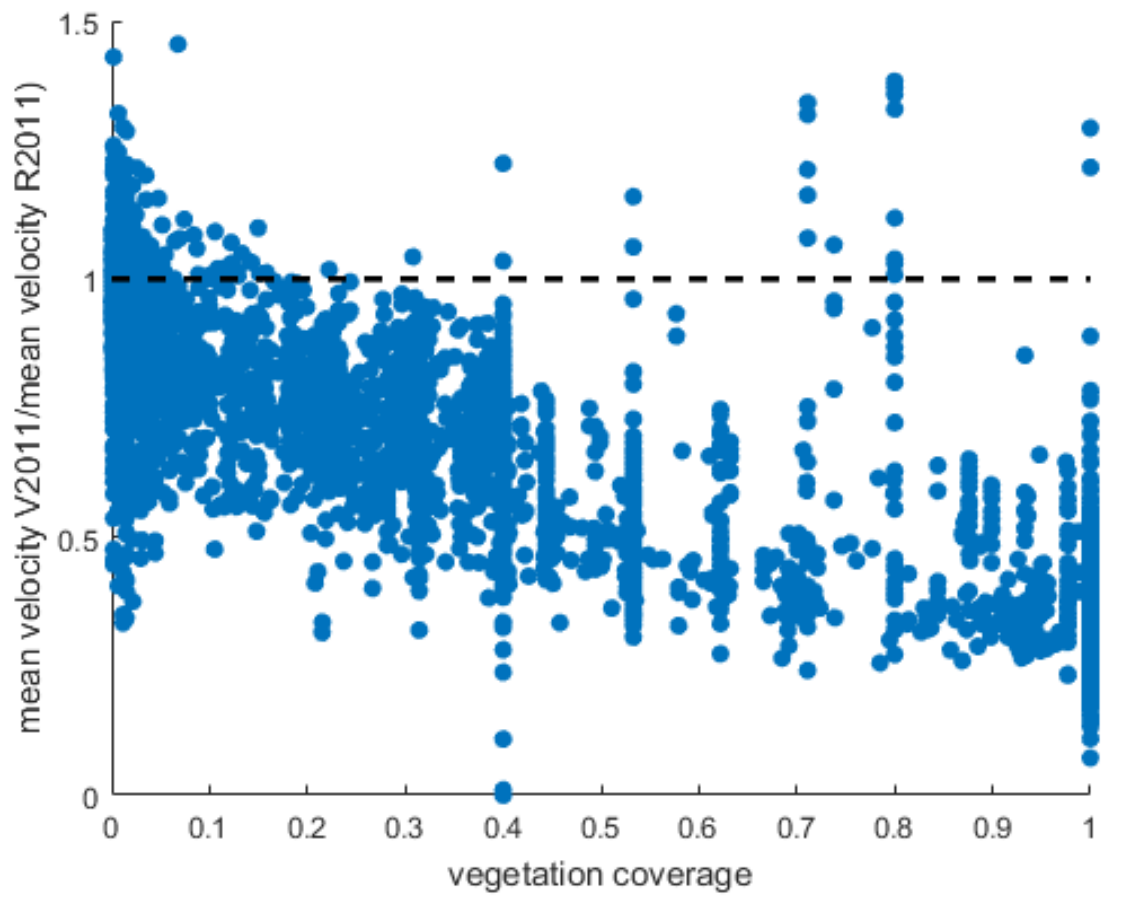

Figure A.2: Ratio of the residual flow velocity of one tidal cycle between the V2011 and R2011 scenarios along vegetation cover of all vegetated cells for one tidal cycle. Values below 1 indicate reduction in flow velocity by vegetation, showing a clear decrease of flow velocity with increasing vegetation cover. 
$-1$

| | 


\section{Appendix B}

\section{Supplementary material for Chapter 3}

Here the parameters used for the dynamic vegetation model are summarized with according references. Two life-stages were parametrized to account for aging of the plants after one year from seedlings to mature vegetation. As a result, plant size, density and resilience against mortality change between life-stages. For both saltmarsh species all parameters are the same.

Table B.1: Physical parameters of the generic saltmarsh vegetation type based on a combination between Spartina anglica and Salicornia ssp.. $t_{1}, t_{2}$ and $t_{3}$ are onset of growth season, onset of maximum biomass in summer and onset of reduced biomass in winter. The seedling-stage changes into mature vegetation after year 1 with a maximum total age of the plant of 20 years.

\begin{tabular}{|c|c|c|c|c|}
\hline Generic and mud-dependent species & unit & $t_{1}$ & $t_{2}$ & $t_{3}$ \\
\hline \multicolumn{5}{|l|}{ Seedling stage (1 year) } \\
\hline plant height $c, e$ & [m] & 0.1 & 0.6 & 0.3 \\
\hline stem diameter ${ }^{d}$ & [m] & 0.005 & 0.01 & 0.01 \\
\hline root length ${ }^{b, e}$ & [m] & 0.05 & 0.2 & 0.2 \\
\hline plant density $^{a}$ & [stems $\left./ m^{2}\right]$ & 500 & 500 & 500 \\
\hline bulk drag $C_{D}$ & {$[-]$} & 1.0 & 1.0 & 1.0 \\
\hline bed roughness $C_{b}$ & {$[\sqrt{m} / \mathrm{s}]$} & 25 & 25 & 25 \\
\hline \multicolumn{5}{|l|}{ Mature vegetation (19 years) } \\
\hline plant height ${ }^{a, c, d}$ & [m] & 0.5 & 1.0 & 0.5 \\
\hline stem diameter $^{a}$ & [m] & 0.01 & 0.01 & 0.01 \\
\hline root length ${ }^{c}$ & {$[\mathrm{~m}]$} & 1.0 & 1.0 & 1.0 \\
\hline plant density $^{a}$ & [stems $\left./ m^{2}\right]$ & 600 & 600 & 600 \\
\hline bulk drag $C_{D}$ & {$[-]$} & 1.1 & 1.1 & 1.1 \\
\hline bed roughness $C_{b}$ & {$[\sqrt{m} / s]$} & 25 & 25 & 25 \\
\hline
\end{tabular}

Note. ${ }^{a}$ Bouma et al. (2013), ${ }^{b}$ Cooper (1982), ${ }^{c}$ Davy et al. (2001)

${ }^{d}$ Nehring and Hesse (2008), ${ }^{e}$ Poppema et al. (2017) 

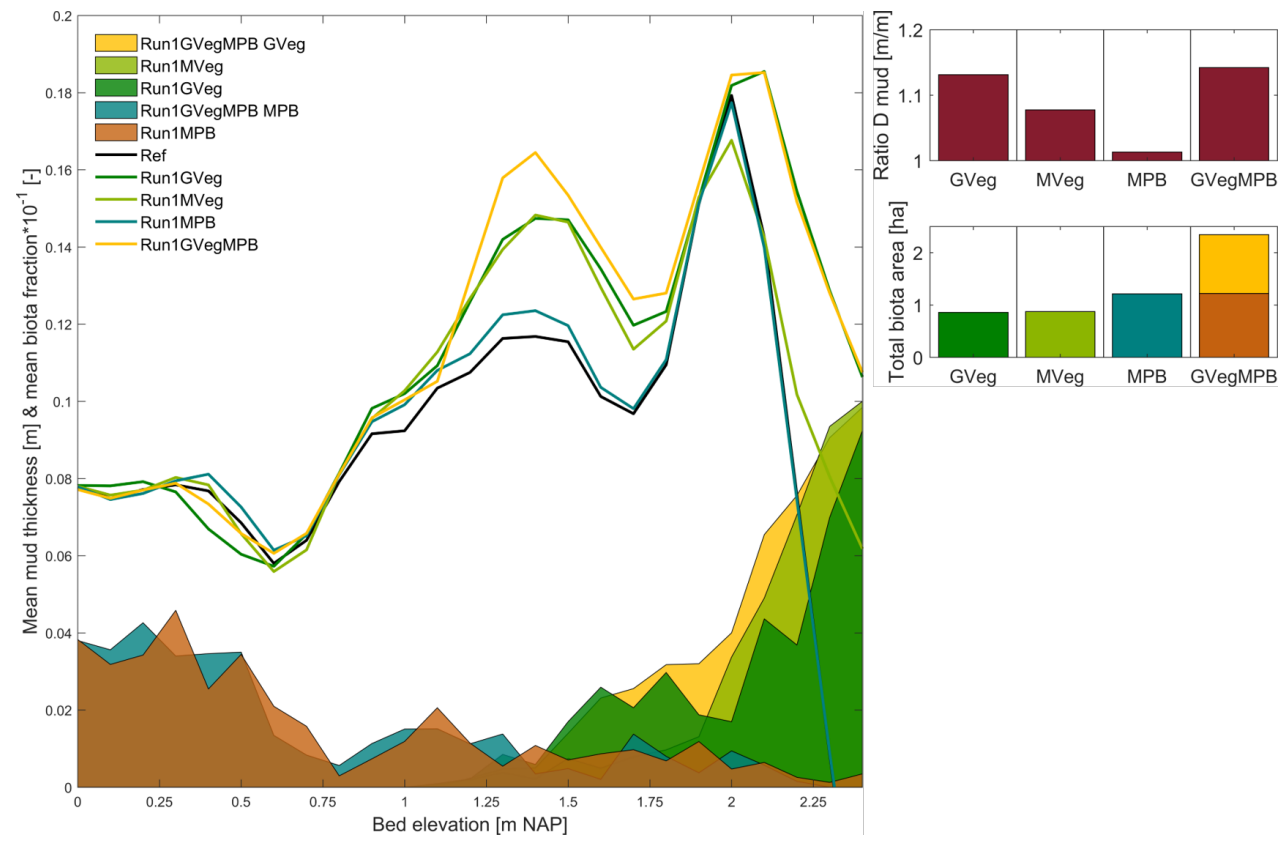

Figure B.1: Mean mud thickness along bed elevation (0.1m-steps) on the tidal shoal of Walsoorden (lines) compared to mean biostabilizer fraction at the end of the simulation (shaded areas). For MPB, the last time-step in the growth season was analyzed. Mean mud thickness increases towards higher bed elevations and reduces at the highest elevations. Saltmarsh vegetation promotes mud accretion at the higher elevations while MPB enhances mud thickness at intermediate elevations. The combined run with both the generic saltmarsh and MPB leads to an overall increasing mud thickness through positive feedbacks that facilitate vegetation growth. The shaded areas represent the mean fraction at each bed elevation class, separated into vegetation and MPB. The bar plot shows the total increase in mean mud thickness (D) on the bar as a ratio compared to the reference run, which is related to increasing biota cover. Biota fraction of GVegMPB combines MPB (red) and GVeg (yellow) as staggered bar.

Table B.2: Mortality parameters of our generic and mud-dependent saltmarsh vegetation species. The values are based on a combination between Spartina anglica and Salicornia ssp.. The seedling-stage changes into mature vegetation after year 1 with a maximum total age of the plant of 20 years.

\begin{tabular}{lcc}
\hline Saltmarsh species & min. threshold & max. threshold \\
\hline Seedling stage (1 year) & & \\
inundation period $^{b}$ & 0.3 & 0.45 \\
uprooting $_{\text {Mature vegetation (19 years) }}$ & $0.25 \mathrm{~m} / \mathrm{s}$ & $0.4 \mathrm{~m} / \mathrm{s}$ \\
inundation period $^{b}$ & & \\
uprooting $^{a}$ & 0.3 & 0.45 \\
\hline
\end{tabular}

Note. ${ }^{a}$ Bouma et al. (2013) $\quad{ }^{b}$ Van Belzen et al. (2017) 


\section{Appendix C}

\section{Supplementary material for Chapter 4}

This document provides supporting information about the validation of the random establishment method (Ripley's K), and additional figures related to the model set-up and part of the results.

Spatial salt marsh colonization and growth is modeled solely through random establishment of vegetation patches. Previous studies simulated vegetation growth through a combination of random establishment and diffusion, representing colonization from seeds and clonal growth from rhizomes (e.g. Schwarz et al., 2014; Temmerman et al., 2007). To reduce the uncertainty of lateral expansion rates in combination with model grid-resolution on our model simulations, which are not well defined in literature, we chose to only use random establishment defining plant colonization. However, by choosing a species-specific initial patch sizes based on field observations (Bouma et al., 2013; Gray and Scott, 1977; Loebl et al., 2006; Van Duin and Sonneveld, 2016), we inherently include a simplified proxy for lateral growth in our model.

We test the validity of our approach to represent scale-dependent feedbacks by determining tussock distributions (random, clustered or regular) of the single-species S1 Spartina scenario, by calculating the Ripley's K (Ripley, 1977). The Ripley's K function analyzes the spatial pattern of point data, by increasing the radius $(\mathrm{t})$ around the observations and calculating the number of occurrences in the circle as a function of $(\mathrm{t})$. Calculated numbers are subsequently averaged over all occurrences to provides the statistic $K(t)$ as a function of the radius $(\mathrm{t})$. Complete spatial randomness is expected a $\mathrm{K}(\mathrm{t})$ proportional to $\pi \mathrm{t} 2$. A more robust estimator of pattern randomness is given be Ripley's $L$ which linearizes and stabilizes variances through $L(t)=\sqrt{ } K(t) / \pi$ (Fortin et al., 2002). Ripley's $L$ was calculated using the spatstat package in $\mathrm{R}$, ver 3.3.1. Inter-patch distances were used to calculate $\mathrm{K}(\mathrm{t})$ and $\mathrm{L}(\mathrm{t})$ and subsequently 100 Monte Carlo iterations were used to calculate the $95 \%$ confidence interval. $\mathrm{L}(\mathrm{t})$ values above the upper confidence interval show that at specific inter-patch distances more points are found than would be expected based on the Poisson distribution pointing to clustered data and scale dependent feedbacks (Van Wesenbeeck et al., 2008). Additionally, we used a second method to test for spatial randomness using the quadrat-test of the same R-package (spatstat).

The extracted vegetation patch centers from the Spartina case resulted in point patterns that were used to calculate $\mathrm{L}(\mathrm{t})$ for inter-patch distances using Ripley's K. Test results (Figure C.1) show establishment of spatial clustering, through $\mathrm{L}(\mathrm{t})$ exiting the confidence interval (gray band), after 8 years. This is also confirmed by the conducted quadrat-test, showing p-values lower the 0.05 (95\% confidence) after 8 years, signifying spatial clustering. This shows the applicability of our approach to represent scale-dependent feedbacks and thus bio-geomorphological interactions shaping salt marsh ecosystems. 

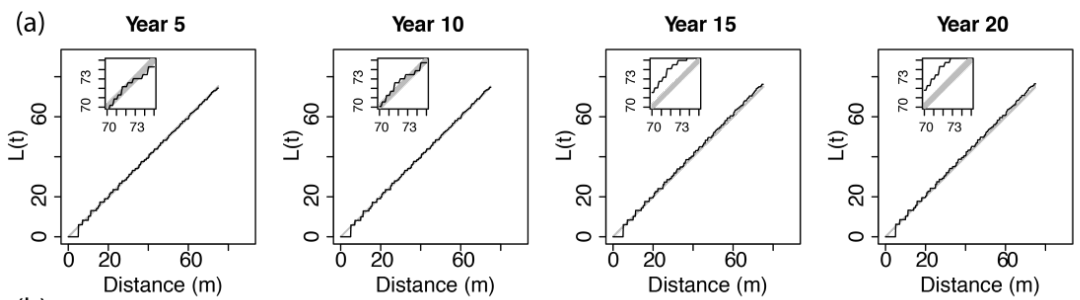

(b)

quadrat.test

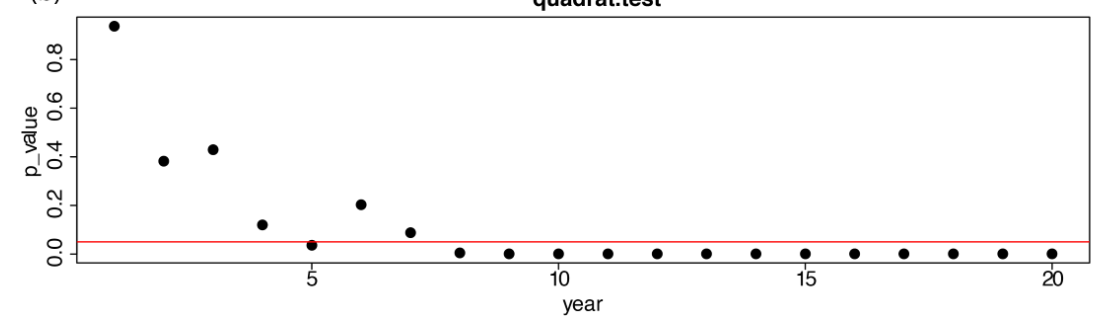

Figure C.1: (a)Ripley's L analysis of the single-species Spartina case, insets show that around 15 years the $L(t)$ (black line) falls outside the expected confidence interval suggesting spatial clustering caused by biogeomorphic feedbacks; (b) shows results of the quadrat-test, which has a null-hypothesis of the point-pattern being randomly distributed and a significance level of 0.05 (red line), showing significant clustering after 6 and 8 years, respectively (black dots under red line).

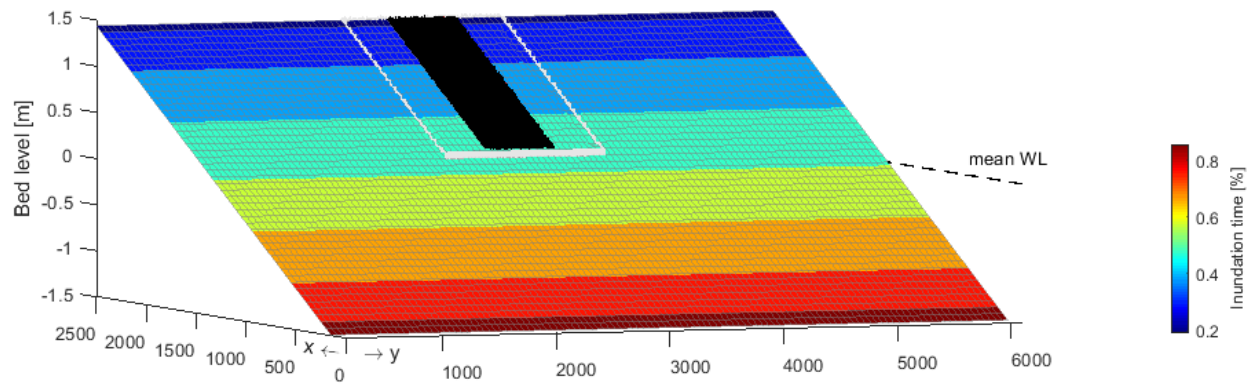

Figure C.2: Model setup using the domain decomposition method of Delft3D. A small high-resolution domain (grid size: $5 \mathrm{~m}$; black rectangle) is inserted in a bigger and coarser domain (grid size: $50 \mathrm{~m}$ ) that is forced by a M2 tidal harmonic water level fluctuation at the boundary (colors represent inundation time as percentage over $1 \mathrm{M} 2$ tide). The white rectangle indicates the domain for which vegetation dynamics and topography are calculated, whereas only the black rectangle is used in analysis, to cancel out unwanted boundary effects from the sides. 


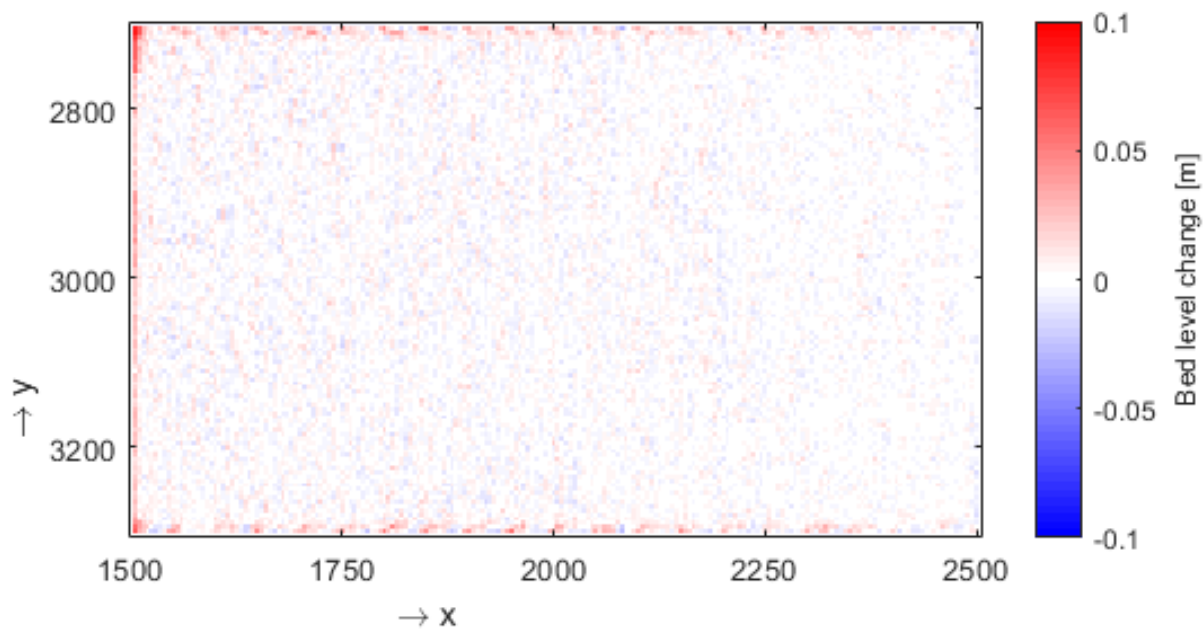

Figure C.3: Bed level change of control run (no vegetation cover) after 8 morphological years. This figure shows that the Engelund-Hansen equation for sediment transport does not induce channel formation in the case of a bare marsh.
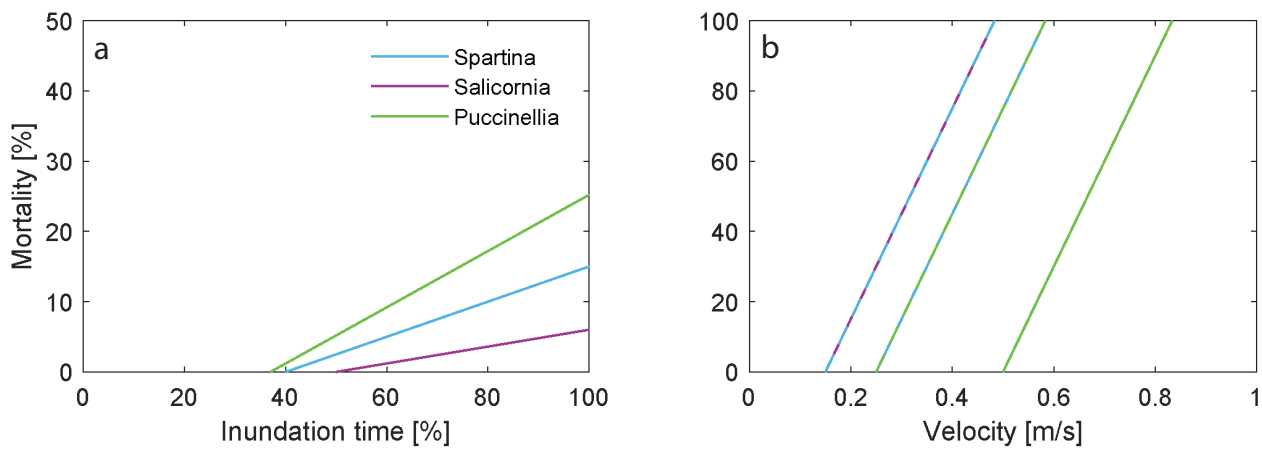

Figure C.4: Spatial variation in growth by means of mortality curves related to stresses: inundation (a) and velocity (b). In case of velocity, a distinction is made between first year and mature plants. Note that in (b) the dashed green line overlaps the solid cyan line and the dashed cyan overlaps the purple. 


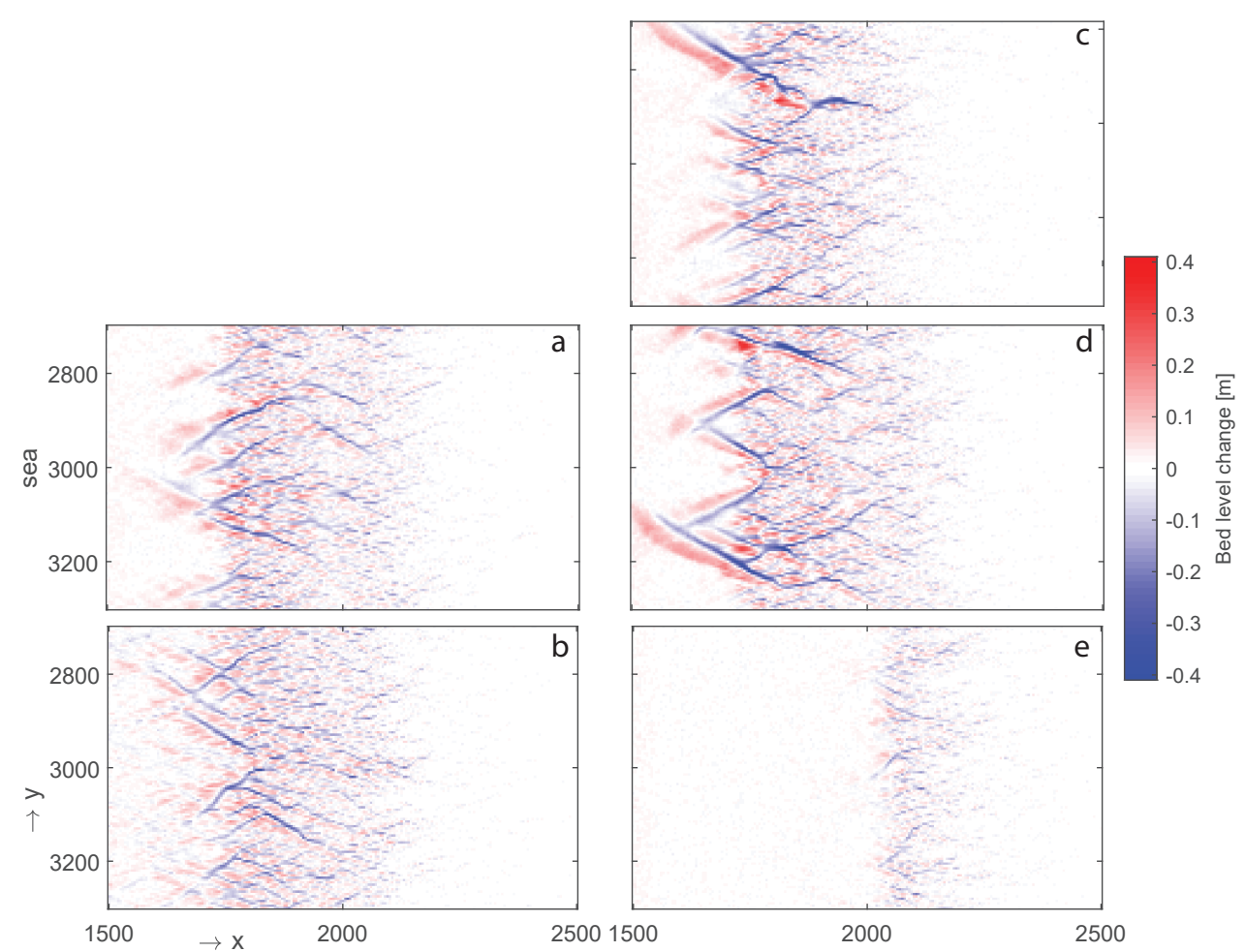

Figure C.5: Bed level change after 20 years for the three-species S2-scenarios: Multi1 (a) and Multi2 (b) and the two-species S2 scenarios: Multi3 (c), Multi4 (d) and Multi5 (e).
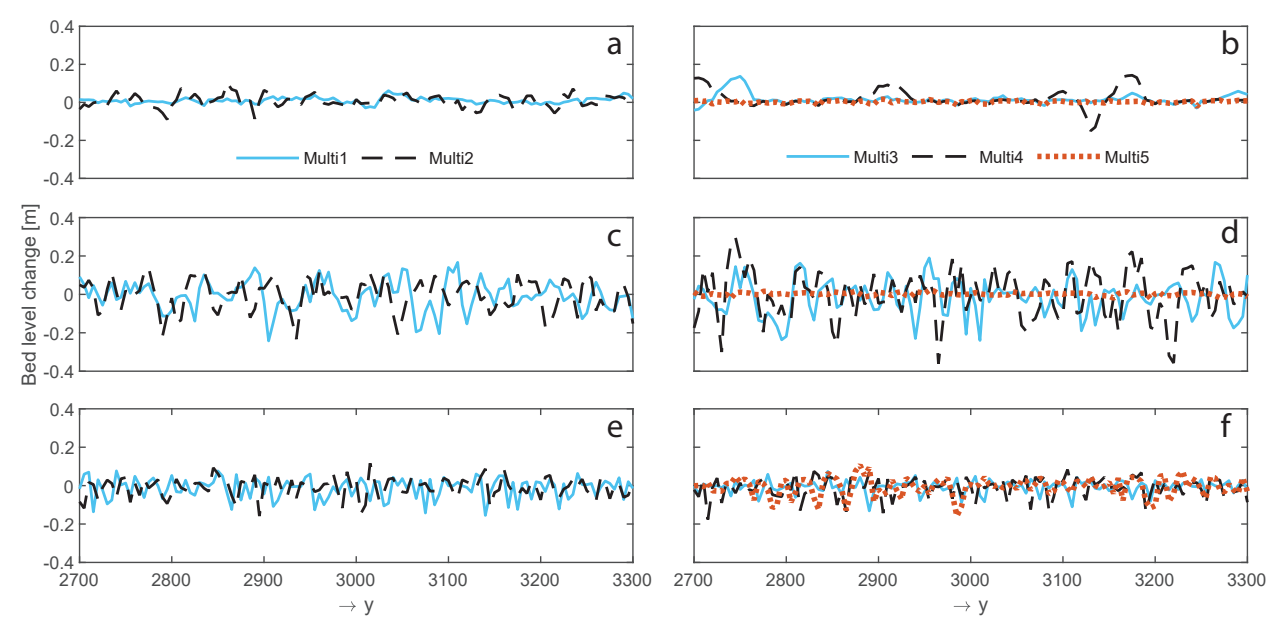

Figure C.6: Cross-sections of relative topography for the S2-scenarios with all species $(k, m, o)$ and with two species $(l, n, p)$ at successive distances from the sea: $150 \mathrm{~m}(\mathrm{k}, \mathrm{l}), 300 \mathrm{~m}(\mathrm{~m}, \mathrm{n})$ and $600 \mathrm{~m}(\mathrm{o}, \mathrm{p})$ 

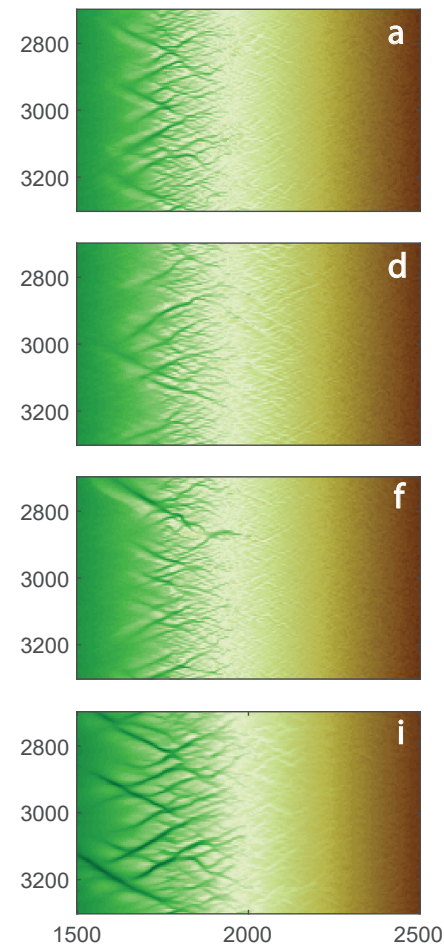
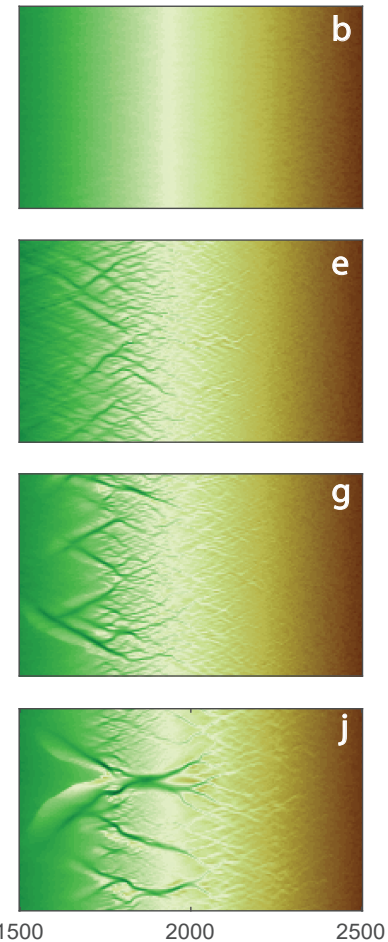
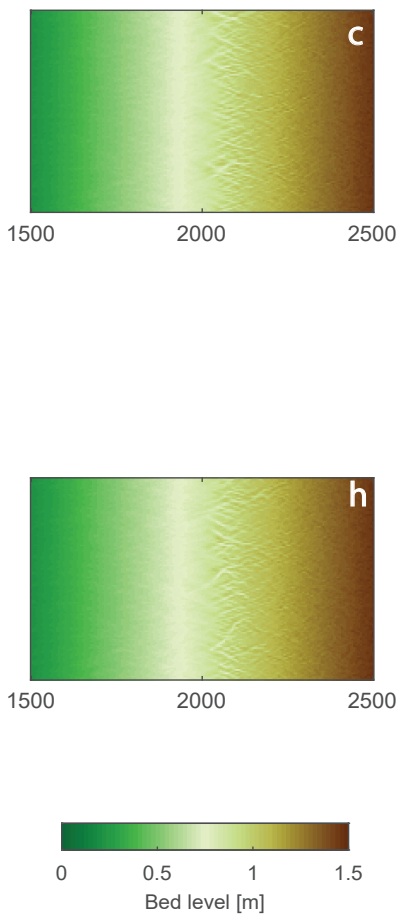

Figure C.7: Topography after 20 years for all scenarios. S1: Spartina (a), Puccinellia (b), Salicornia (c). S2: Multi1 (d), Multi2 (e), Multi3 (f), Multi4 (g), Multi5 (h). S3: Spar2Sal (i) and Puc2Spar (j). 

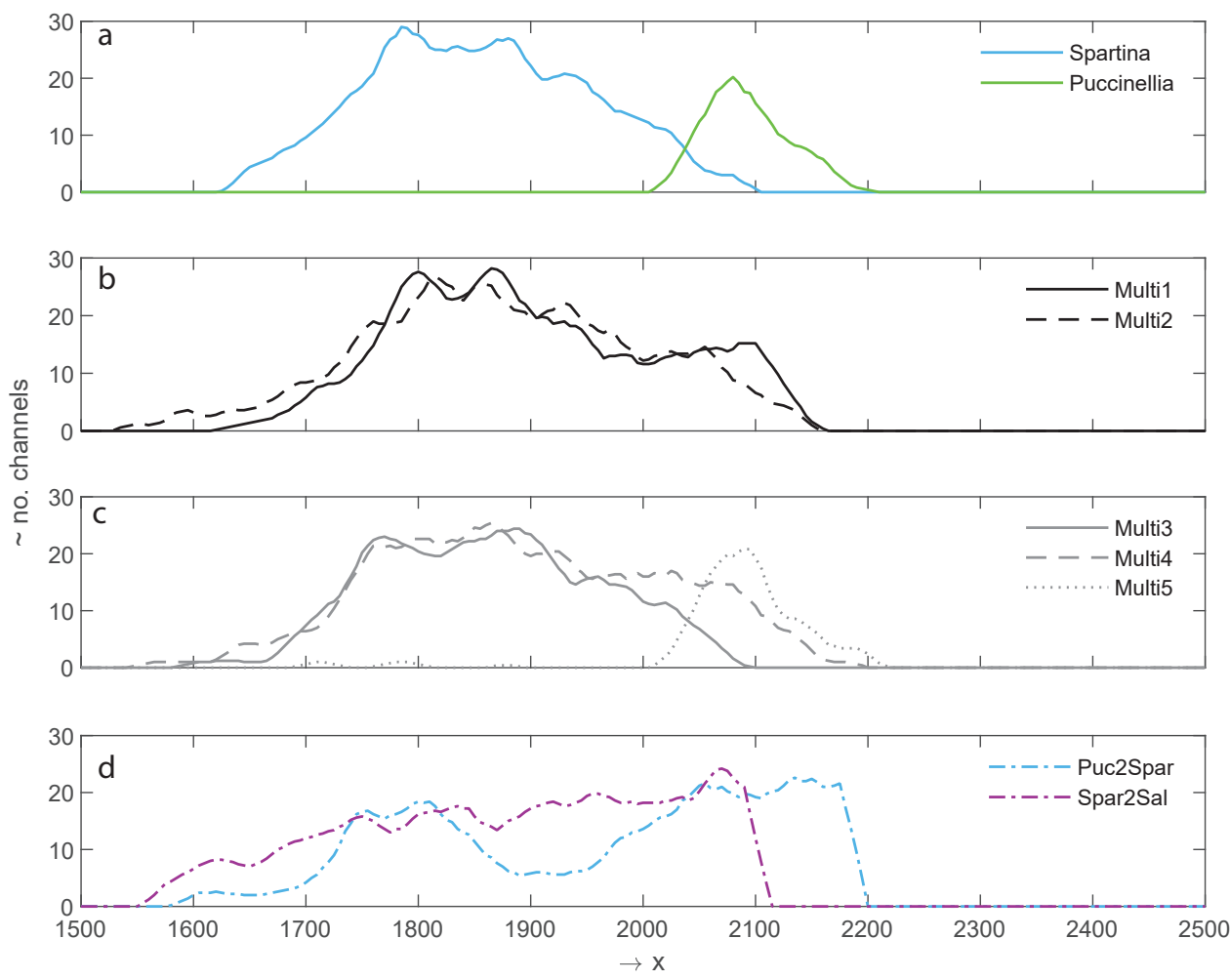

Figure C.8: Number of channels for all x locations (landward) after 20 years for a) S1-scenarios (Salicornia is not included since it did not develop channels), b) three-species S2-scenarios, c) two-species S2-scenarios and d) S3-scenarios. Number of channels is approximated based on the number of zero crossings divided by 2 . Since this measure is subject to domain width it can only be analyzed in a relative matter. 

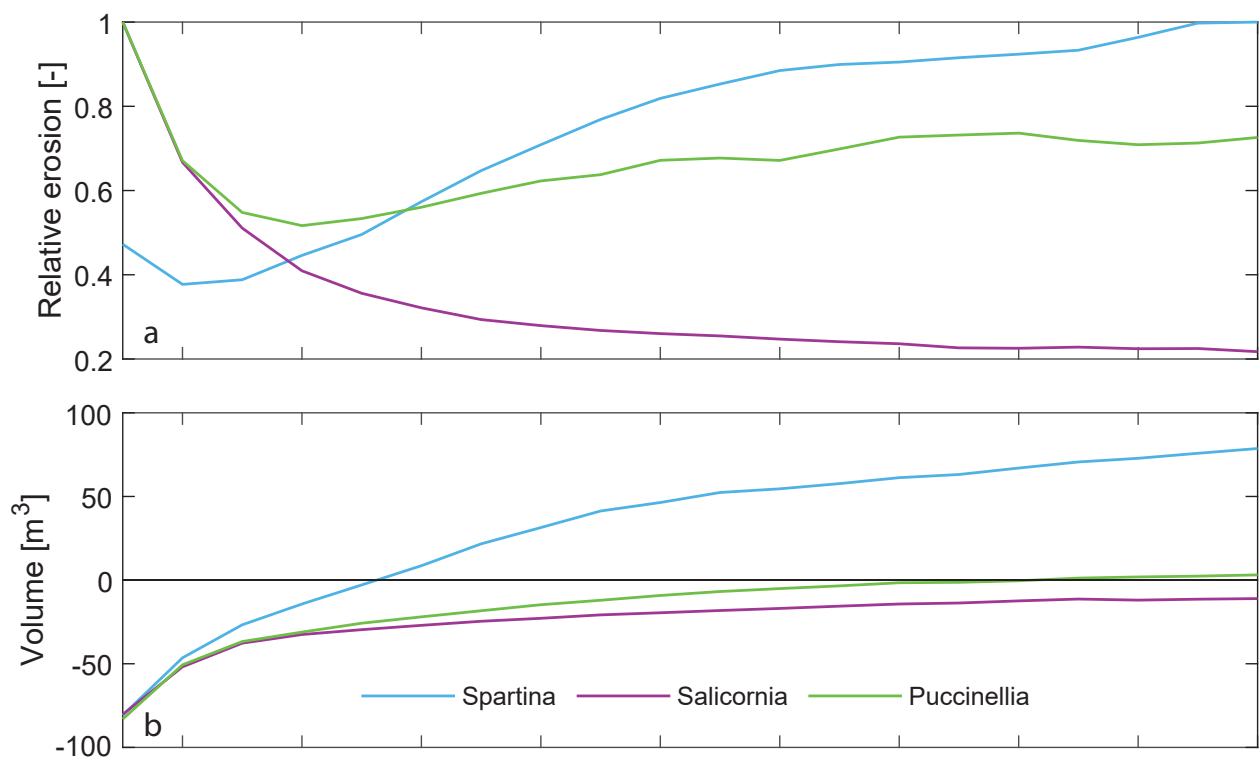

Figure C.9: Temporal evolution of relative erosion (a) and net erosion (b) for the S1-scenarios. (a) Relative erosion is calculated as the annual amount of erosion over the entire domain divided by the maximum amount of annual erosion over the full simulation period (Spartina: $850 m_{3}$, Puccinellia and Salicornia: $400 m_{3}$ ). (b) Net erosion is calculated as the difference between annual amounts of erosion and accretion; negative values indicate accretion dominates. 
$-1$

| | 


\section{Appendix D}

\section{Supplementary material for Chapter 5}

The supplementary material presents a table with the detailed species values obtained from Cozzoli et al. (2019) and adjusted for the presented models (Table D.1). Moreover, the figures show the development of species cover and morphology over the simulation time (Figure D.1 and D.2) and provide more detail on how the hydrodynamics and suspended sediment transport are altered under the presence of biota (Figure D.3 and D.4).

Table D.1: Calculation of the species values in the model based on the measurements in Cozzoli et al. (2019) $\left({ }^{*}\right)$. The factor between the biotic and abiotic results of the experiments was used as a guideline to determine the critical threshold for erosion $\left(\tau_{\text {crit }}\right)$ and the erosion rate $(M)$ for the modeled sediment.

\begin{tabular}{lcccccc}
\hline & $\tau_{\text {crit }}{ }^{*}$ & $\tau_{\text {crit }, \text { species }}{ }^{*} / \tau_{\text {crit, abiotic }}{ }^{*}$ & $\tau_{\text {crit }, \text { model }}$ & $M^{*}$ & $M_{\text {species }} / M_{\text {abiotic }}$ & $M$ in model $\left[\mathrm{kg} / \mathrm{m}^{2} / \mathrm{s}\right]$ \\
\hline abiotic & 0.11 & - & 0.2 & 40.89 & - & 0.0001 \\
A. marina & 0.0614 & 0.5582 & 0.11 & 266 & 6.507 & 0.0005 \\
C. volutator & 0.0095 & 0.0864 & 0.02 & 231 & 5.21 & 0.0004 \\
\hline
\end{tabular}




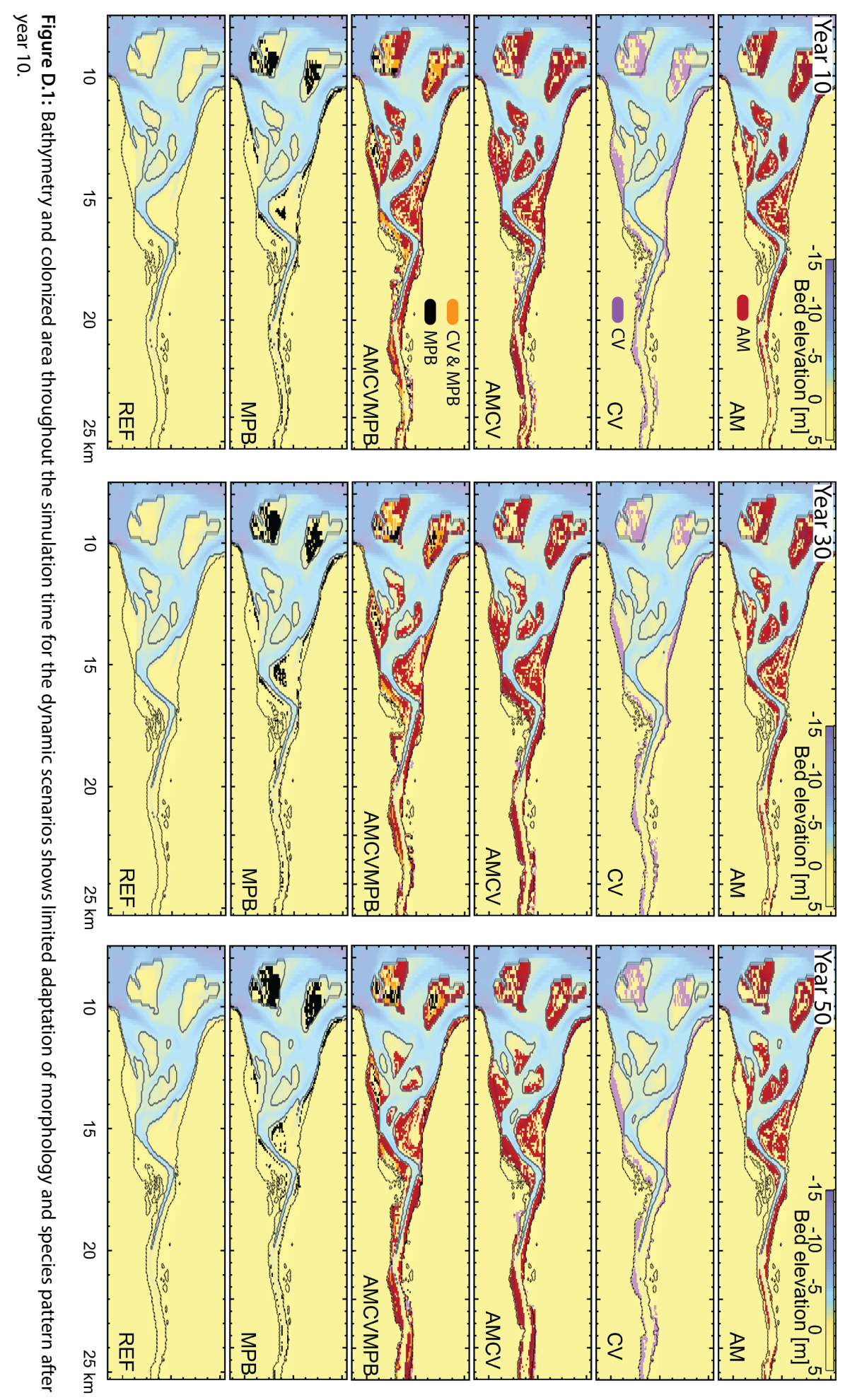




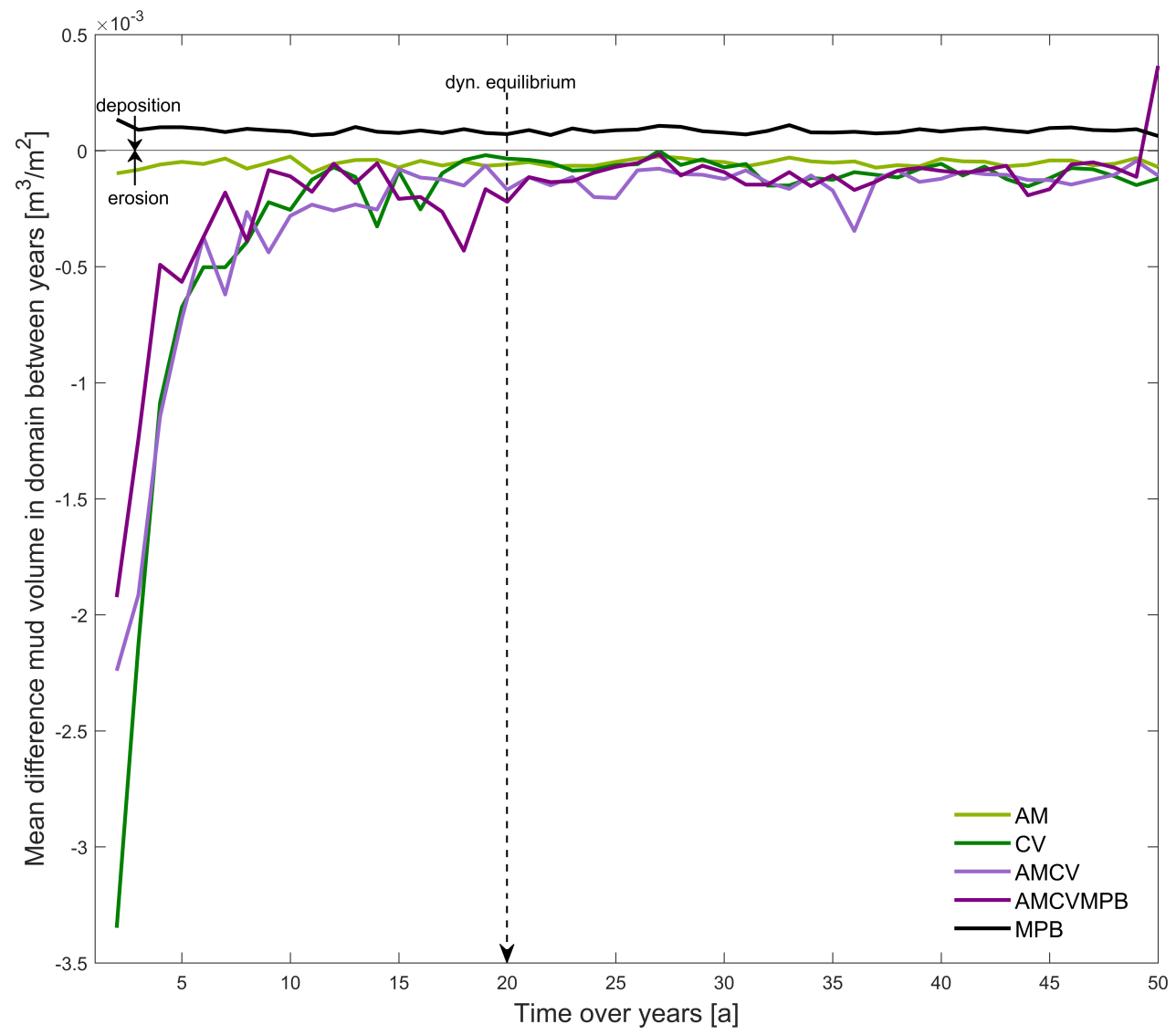

Figure D.2: Trapping efficiency as difference in mud thickness between consecutive years compared to reference scenario shows that the estuary is depositional under MPB and erosional under bioturbation. MPB and AM are constant over the entire simulation period while CV, AMCV and AMCVMPB reach a dynamic equilibrium around year 20, after which the mud erosion rate is close to constant.
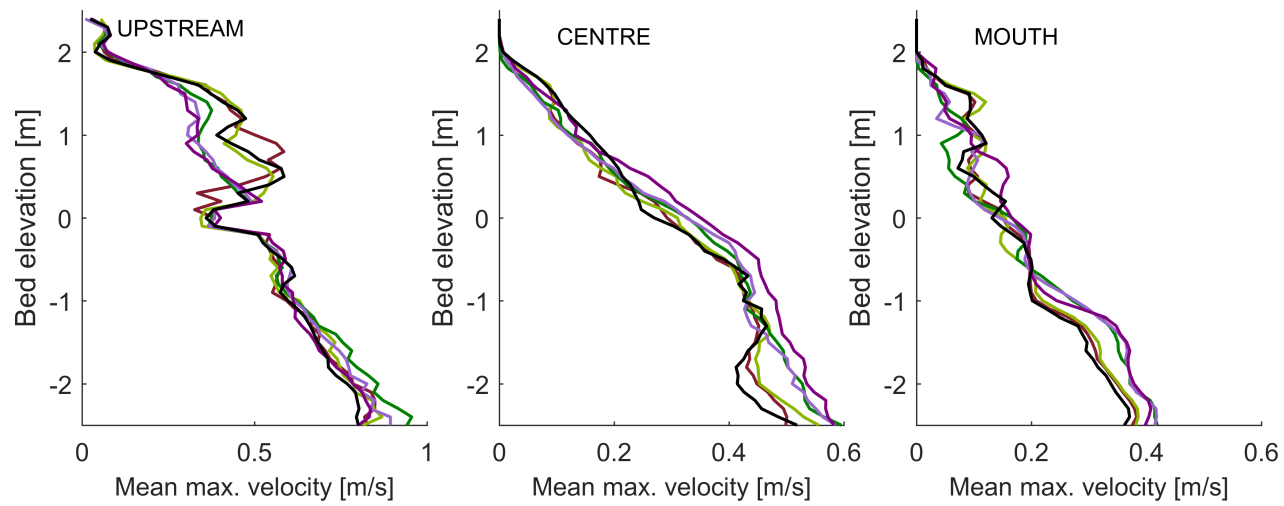

Figure D.3: Mean of absolute maximum velocities by bed elevation for the three reaches of the estuary, showing that the smoothening of the bed elevations with bioturbation resulted in smaller velocities above mean water $(\mathrm{MW}=0 \mathrm{~m})$ but larger velocities below. Biostabilization resulted in the opposite effects. 

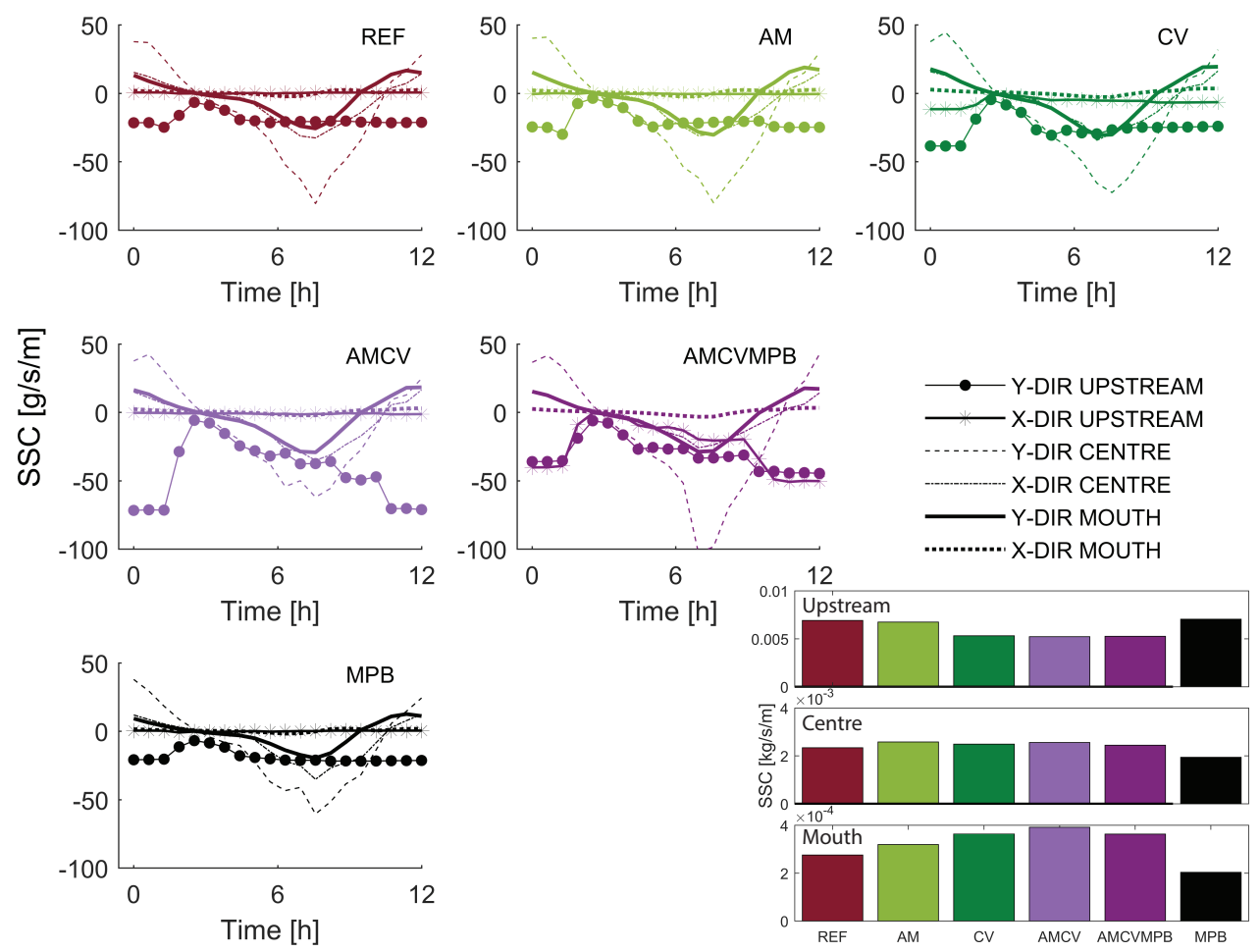

Figure D.4: Mean suspended sediment transport is altered by eco-engineering in the three reaches of the estuary, both in direction (lines) and magnitude (bars). Bioturbation leads to enhanced along current mud transport rates (Y-direction) upstream and in the center, whereas MPB reduces mean suspended sediment magnitudes, especially in the center and mouth. 


\section{Appendix E}

\section{Supplementary material for Chapter 6}

\section{E.1 Mud cover for all scenarios}

The mud thickness in the estuary at the end of the simulation varies between scenarios (Figure E.1). VS2-VS3 show mud accumulation mainly in the center of the estuary and in the tidal embayment, whereas VS1 and VS4 promote mud accretion towards the mouth and on tidal bars.

\section{E.2 The coupled model}

\section{E.2.1 The hydro-morphodynamic model}

The model domain consists of an idealized estuary based on the Dovey estuary (further described in (Braat et al., 2017) that includes a tidal embayment close to the mouth of the estuary. We assume an alluvial systems as there are no constraints to the development of the estuary by bed-rock. The length of the entire domain was approximately $42 \mathrm{~km}$ with a slope in the estuarine-river part of $0.155 \varnothing \%$, a channel width of around $100 \mathrm{~m}$ upstream and of $4,000 \mathrm{~m}$ at the mouth. The model contains both sand and mud, with the former being computed through equilibrium transport at the boundaries and the latter through a constant river supply. The initial bathymetry was chosen after the formation of tidal bars and a natural build up of a mud cover in sheltered areas and on the floodplains. The effect of land plant cover and evolution was captured by an introduction of each vegetation stage to the model separately and comparing the final morphologies with an uncolonized reference run.

Delft3D solves the shallow water equations (Lesser et al., 2004) (eq. E.8). Sand transport for the non-cohesive regime (mud content $\leq 40 \%$ in top layer of the cell) is computed by Engelund-Hansen as

$$
q_{s}=0.05 U^{5} /\left(\sqrt{g} C^{3} \Delta^{2} D_{50}\right)
$$

where $q_{s}$ is sediment transport $\left(m^{3} m^{-1} s^{-1}\right), \mathrm{U}$ is flow velocity $\left(m s^{-1}\right), \Delta$ is relative density and $D_{50}$ median grain size. Mud transport is computed by the Partheniades-Krone formulation (Partheniades, 1965) that calculates total transport as

$$
E_{m}=\operatorname{MS}\left(\tau_{c w}, \tau_{c r, e}\right)
$$

with $E_{m}$ the erosional flux $\left(\mathrm{kgm}^{-2} \mathrm{~s}^{-1}\right), \tau_{c w}$ maximum shear stress at the bed $\left(\mathrm{N} \mathrm{m}^{-2}\right)$ and $S$ erosional step function. If the critical mud content of $40 \%$ is exceeded, both sand and mud are computed by equation E.2. For the representation of the microbial mats (VS1), the $\tau_{c r, e}$ in the above equation is increased locally, leading to lower erodibility of the mud. 
The model is forced by seaward model boundary based on an M2-tide of $2 \mathrm{~m}$ amplitude and a constant river discharge of $200 \mathrm{~m}^{3} / \mathrm{s}$ applied from the upstream river boundary. Waves and salinity are neglected as the computation of the former is highly expensive and salinity has only small effects on large-scale sediment transport magnitudes. To accelerate morphological computations we applied a morphological acceleration factor of 365 (Lesser et al., 2004). The morphological acceleration factor is efficient and widely used to speed up
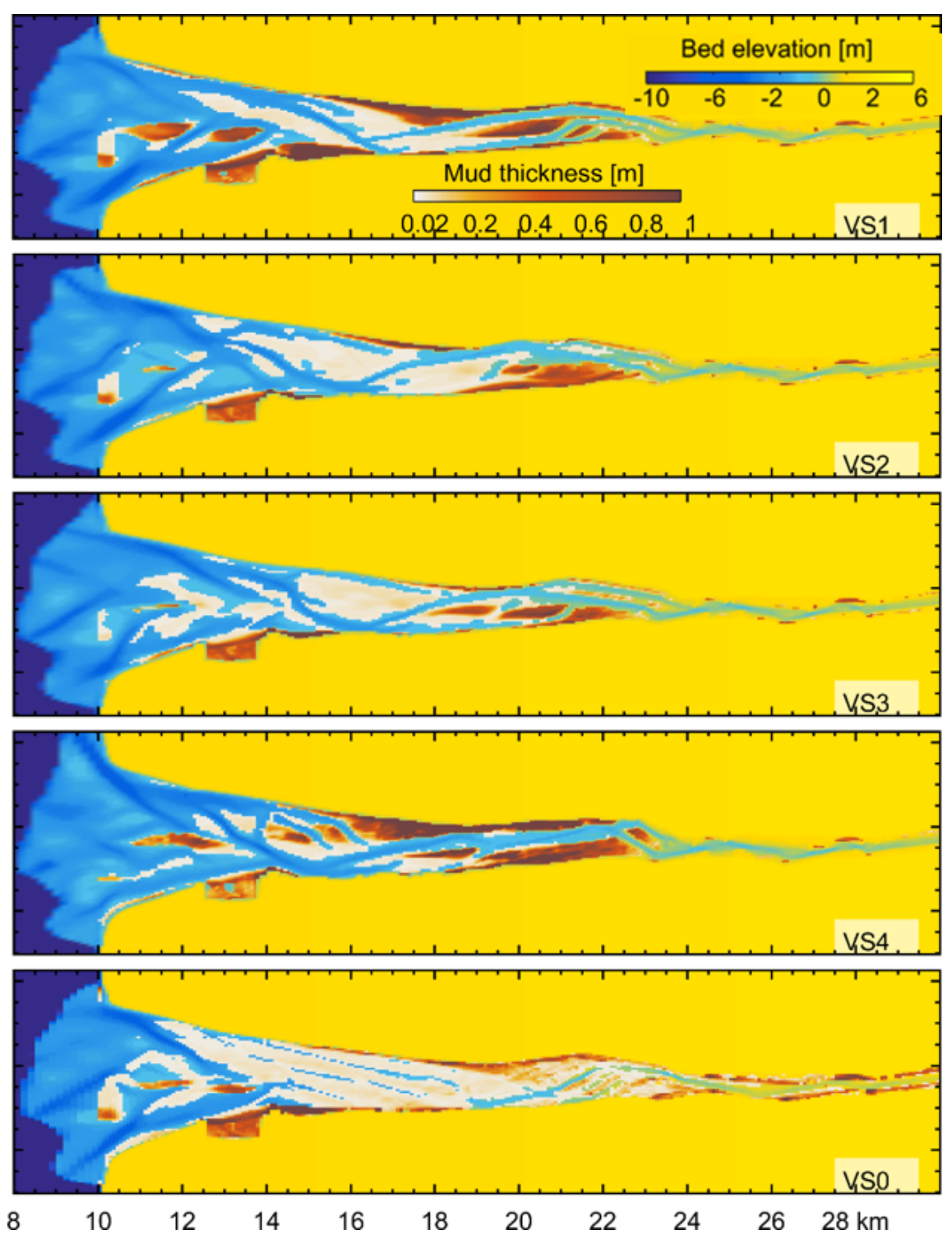

Figure E.1: Final domain from mouth (left) to river (right) with bathymetry (blue-yellow colors) and mud deposits along the sides of the estuary (brown colors). 
Table E.1: Model parameters as defined in the Delft3D model.

\begin{tabular}{lcc}
\hline Parameter & value & unit \\
Numerical settings & & min \\
\hline Total simulation time & 216000 & min \\
Numerical time-step & 0.1 & 1/ecological year \\
No. ecological time-steps & 2 & $\mathrm{~m}$ \\
Tidal amplitude & 2 & $\mathrm{~m}^{3} / \mathrm{s}$ \\
River discharge & 200 & $\mathrm{~m}$ \\
Sand & & $\mathrm{kg} / \mathrm{m}^{3}$ \\
\hline$D_{50}$ & $2 e^{-4}$ & \\
Dry bed density & 1600 & $\mathrm{~m} / \mathrm{s}$ \\
Mud & & $\mathrm{N} / \mathrm{m}^{2}$ \\
\hline Settling velocity mud & $5 e^{-4}$ & $\mathrm{~kg} / \mathrm{m}^{2} / \mathrm{s}$ \\
Crit. bed shear stress for erosion & 0.2 & $\mathrm{~kg} / \mathrm{m}^{3}$ \\
Erosion parameter & $1 e^{-4}$ & $\mathrm{mg} / \mathrm{l}$ \\
Dry bed density & 1000 & \\
Boundary concentration & 40 & $\mathrm{~m}$ \\
Bed settings & & $\mathrm{m}$ \\
\hline Active layer thickness & $5 e^{-2}$ & - \\
Max. storage layer thickness & $5 e^{-2}$ & \\
Morphological acceleration factor & 365 & \\
\hline
\end{tabular}

long-term morphodynamic simulations (e.g. Braat et al., 2017). The details of the hydromorphodynamic model are summarized in Table E.1.

\section{E.2.2 Computations of the microbial mats (VS1)}

Linked with the secretion of extra-polymeric substances (EPS) microbial mats stabilize the sediment and reduce local erosion (van de Koppel et al., 2001). We account for this effect by an alteration of the resuspension properties of the local mud fraction. Hereby, we assume that microbial mats live on top of the sediments altering the critical bed shear stress for erosion $\tau_{c r, e}$ of the mud while the erosion parameter $M\left(\mathrm{~kg} \mathrm{~m}^{-2} \mathrm{~s}^{-1}\right)$ remains unchanged. This directly affects the erosion flux $E_{m}$ of the mud between the bed and the water column $(\mathrm{kg}$ $m^{-2} s^{-1}$ ) in the Partheniades-Krone formulation (eq. E.2).

Microbial mats were updated each coupling interval with the Delft3D model as a function of inundation period $i$ and mud fraction $f_{\text {mud }}$ in the top layer

$$
M P B_{\text {est }}=f\left(\mathrm{i}, f_{\text {mud }}\right)+M P B_{\text {pre }}
$$

indirectly selecting sheltered areas with limited erosional and depositional processes (Herman et al., 2001). In cells where microbial mats established, the critical shear stress of the mud fraction was increased by a factor of 4 from $0.2 \mathrm{~N} \mathrm{~m}^{-2}$ to $0.8 \mathrm{~N} \mathrm{~m}^{-2}$ as reported in Le Hir et al. (2007).

\section{E.2.3 Computations of the vegetation cover (VS2-4)}

The vegetation code constitutes rules for colonization, growth and mortality that describe dynamic, i.e. temporally and spatially varying, vegetation fractions. Colonization of the vegetation occurs every year where vegetation establishes on all intertidal cells with a fraction 
of 0.5 (of a maximum fraction that can be colonized of 1 ). Second, vegetation mortalities are computed by reducing the vegetation fraction based on a linear function for each of the three pressures, inundation period, desiccation period and flow velocity (Figure 2). Moreover, the vegetation fractions that occur in numerical cells with bed level changes that exceed the plant sizes are assumed to be eroded or buried and die off entirely. Third, the sizes of the remaining vegetation fractions grow linearly (stem height, diameter and root length). For VS4, a second life-stage represents aging of the arborescent plants that reach larger plant dimensions and can cope with larger stresses. After surviving ten couplings (representative for five-year-old vegetation), the VS4 vegetation is updated to the second life-stage.

\section{E.2.4 Interactions between the hydro-morphodynamic model and the vegetation code}

Each coupling, the settlement locations and surface fractions of the vegetation and their physical properties (height, stem diameter, density) are fed back into the hydro-morphodynamic model. To account for vegetation effects, we used the trachytope approach with the Baptistformula (Baptist et al., 2007) that allows for several vegetation fractions and life-stages in one numerical cell. The Baptist-formula calculates a net roughness $C[\sqrt{m} / s]$ from a combination of the bed roughness $C_{b}[\sqrt{m} / s]$ and detailed vegetation parameters, such as vegetation height $h_{v}[\mathrm{~m}]$, vegetation density $n\left[\mathrm{~m} / \mathrm{m}^{2}\right.$, and a bulk drag $C_{D}[-]$. Depending on the relative local water depth $h[\mathrm{~m}], C$ is computed as

$$
\mathrm{C}=\left\{\begin{array}{l}
C_{b}+\frac{\sqrt{g}}{\kappa} \ln \left(\frac{h}{h_{v}}\right) \sqrt{1+\frac{C_{D} n h_{v} C_{b}^{2}}{2 g}}, \text { if } \mathrm{h} \geq h_{v} \\
C_{b}, \text { if } \mathrm{h}<h_{v}
\end{array}\right.
$$

with $g$ is gravity $\left[\mathrm{kg} / \mathrm{s}^{s}\right], \kappa=0.41[-]$ von-Kármán constant and $C_{b}=25[\sqrt{\mathrm{m}} / \mathrm{s}]$, which is derived from the Manning of the vegetated bars of 0.028 and a water depth of $0.1 \mathrm{~m}$. To compensate for higher local sediment transport induced by increased $C$, an additional flow resistance $-\lambda / 2^{\star} u^{2}$ is included in the flow solver, where $\lambda$ is defined as

$$
\lambda=\left\{\begin{array}{l}
C_{D} n \frac{h_{v}}{h} \frac{C_{b}^{2}}{C^{2}}, \text { if } \mathrm{h} \geq h_{v} \\
C_{D} n, \text { if } \mathrm{h}<h_{v}
\end{array}\right.
$$

Finally, for each vegetation fraction present in each cell, both $\lambda$ and $C$ are weighted according to their relative coverage $f_{i}$

$$
C_{\text {total }}=\sum_{i} f_{i} C_{i}
$$

and

$$
\lambda_{\text {total }}=\sum_{i} f_{i} \lambda_{i}
$$


The hydrodynamic model computes water levels and flow velocities through mass and momentum conservation. With each ecological update, the settlement locations and surface fractions of the vegetation and the physical properties (height, stem diameter, density) were fed back into the Delft3D-model. The final roughness $\mathrm{C}$ and the drag $\lambda$ were implemented in the momentum equation:

$$
\frac{\delta u}{\delta t}+u \frac{\delta u}{\delta x}=-g \frac{\delta \eta}{\delta x}+v \frac{\delta^{2} u}{\delta x^{2}}-g \frac{u|u|}{C^{2} h}-\frac{\lambda}{2} u^{2}
$$


$-1$

| | 


\section{References}

Adam, P. (1993). Saltmarsh ecology. Cambridge University Press.

Algeo, T. J. and S. E. Scheckler (1998). Terrestrial-marine teleconnections in the Devonian: links between the evolution of land plants, weathering processes, and marine anoxic events. Philosophical Transactions of the Royal Society of London. Series B: Biological Sciences 353.1365, pp. 113-130.

Alkemade, R, A Wielemaker, P. Herman, and M. Hemminga (1994). Population dynamics of Diplolaimelloides bruciei, a nematode associated with the salt marsh plant Spartina anglica. Marine Ecology Progress Series 105.

Allen, C. R., D. G. Angeler, A. S. Garmestani, L. H. Gunderson, and C. S. Holling (2014). Panarchy: theory and application. Ecosystems 17.4, pp. 578-589.

Allen, J. R. (2000). Morphodynamics of Holocene salt marshes: a review sketch from the Atlantic and Southern North Sea coasts of Europe. Quaternary Science Reviews 19.12, pp. 1155-1231.

Austen, I, T. J. Andersen, and K. Edelvang (1999). The influence of benthic diatoms and invertebrates on the erodibility of an intertidal mudflat, the Danish Wadden Sea. Estuarine, Coastal and Shelf Science 49.1, pp. 99-111.

Baar, A., M. B. Albernaz, W. Van Dijk, and M. Kleinhans (2019). Critical dependence of morphodynamic models of fluvial and tidal systems on empirical downslope sediment transport. Nature communications 10.1, pp. 1-12.

Balke, T., P. M. Herman, and T. J. Bouma (2014). Critical transitions in disturbance-driven ecosystems: identifying $\mathrm{W}$ indows of O pportunity for recovery. Journal of Ecology 102.3, pp. 700-708.

Balke, T., P. C. Klaassen, A. Garbutt, D. van der Wal, P. M. Herman, and T. J. Bouma (2012). Conditional outcome of ecosystem engineering: A case study on tussocks of the salt marsh pioneer Spartina anglica. Geomorphology 153, pp. 232-238. DOI:HTTPS://DOI.ORG/10.1016/J.GEOMORPH.2012.03. 002 .

Balke, T., M. Stock, K. Jensen, T. J. Bouma, and M. Kleyer (2016). A global analysis of the seaward salt marsh extent: The importance of tidal range. Water Resources Research 52.5, pp. 3775-3786. DOI:HTTPS://DOI.ORG/10.1002/2015WR018318.

Ballent, A., P. L. Corcoran, O. Madden, P. A. Helm, and F. J. Longstaffe (2016). Sources and sinks of microplastics in Canadian Lake Ontario nearshore, tributary and beach sediments. Marine pollution bulletin 110.1, pp. 383-395.

Baptist, M., V. Babovic, J Rodríguez Uthurburu, M Keijzer, R. Uittenbogaard, A Mynett, and A Verwey (2007). On inducing equations for vegetation resistance. Journal of Hydraulic Research 45.4, pp. 435-450. DOI:HTTPS://DOI.ORG/10.1002/2014GL061666.

Barbier, E. B., S. D. Hacker, C. Kennedy, E. W. Koch, A. C. Stier, and B. R. Silliman (2011). The value of estuarine and coastal ecosystem services. Ecological monographs 81.2, pp. 169-193.

Beeftink, W. (1985). Population dynamics of annual Salicornia species in the tidal salt marshes of the Oosterschelde, The Netherlands. Vegetatio 61.1-3, pp. 127-136.

Berry, C. M. and M. Fairon-Demaret (1997). A reinvestigation of the cladoxylopsid Pseudosporochnus nodosus Leclercq et Banks from the Middle Devonian of Goé, Belgium. International Journal of Plant Sciences 158.3, pp. 350-372.

Berry, C. M. and J. E. Marshall (2015). Lycopsid forests in the early Late Devonian paleoequatorial zone of Svalbard. Geology 43.12, pp. 1043-1046.

Bertness, M. D. and G. H. Leonard (1997). The role of positive interactions in communities: lessons from intertidal habitats. Ecology 78.7, pp. 1976-1989.

Bertness, M. D. and S. C. Pennings (2002). Spatial variation in process and pattern in salt marsh plant communities in eastern North America. In: Concepts and controversies in tidal marsh ecology. Springer, pp. 39-57. 
Besseling, E., A. Wegner, E. M. Foekema, M. J. Van Den Heuvel-Greve, and A. A. Koelmans (2013). Effects of microplastic on fitness and PCB bioaccumulation by the lugworm Arenicola marina (L.). Environmental science \& technology 47.1, pp. 593-600.

Best, J. (2019). Anthropogenic stresses on the worlds big rivers. Nature Geoscience 12.1, pp. 7-21.

Best, Ü. S., M Van der Wegen, J Dijkstra, P. Willemsen, B. Borsje, and D. J. Roelvink (2018). Do salt marshes survive sea level rise? Modelling wave action, morphodynamics and vegetation dynamics. Environmental modelling \& software 109, pp. 152-166. DOI:HTTPS://DOI.ORG/10.1016/J.ENVsOFT. 2018.08.004.

Beukema, J and J De Vlas (1979). Population parameters of the lugworm. Arenicola marina 150.

Beukema, J. and E. Flach (1995). Factors controlling the upper and lower limits of the intertidal distribution of two Corophium species in the Wadden Sea. Marine Ecology Progress Series 125, pp. 117126.

Bockelmann, A.-C., J. P. Bakker, R. Neuhaus, and J. Lage (2002). The relation between vegetation zonation, elevation and inundation frequency in a Wadden Sea salt marsh. Aquatic botany 73.3, pp. 211221.

Boechat Albernaz, M., L. Roelofs, H. J. Pierik, and M. G. Kleinhans (2020). Natural levee evolution in vegetated fluvial-tidal environments. Earth Surface Processes and Landforms. DoI:10.1002/ESP. 5003.

Bolle, A., Z. B. Wang, C. Amos, and J. De Ronde (2010). The influence of changes in tidal asymmetry on residual sediment transport in the Western Scheldt. Continental Shelf Research 30.8, pp. 871-882.

Borsje, B. W., T. J. Bouma, M. Rabaut, P. M. Herman, and S. J. Hulscher (2014). Formation and erosion of biogeomorphological structures: A model study on the tube-building polychaete Lanice conchilega. Limnology and oceanography 59.4, pp. 1297-1309.

Borsje, B. W., M. B. de Vries, T. J. Bouma, G. Besio, S. J. Hulscher, and P. M. Herman (2009). Modeling bio-geomorphological influences for offshore sandwaves. Continental Shelf Research 29.9, pp. 12891301.

Botsford, L. W., J. C. Castilla, and C. H. Peterson (1997). The management of fisheries and marine ecosystems. Science 277.5325, pp. 509-515.

Bouma, T., M. De Vries, E Low, G Peralta, I. v. Tánczos, J. van de Koppel, and P. J. Herman (2005). Trade-offs related to ecosystem engineering: A case study on stiffness of emerging macrophytes. Ecology 86.8, pp. 2187-2199. DOI:HTTPS://DOI.ORG/10.1890/04-1588.

Bouma, T., M Friedrichs, P Klaassen, B. Van Wesenbeeck, F. Brun, S Temmerman, M. Van Katwijk, G Graf, and P. Herman (2009a). Effects of shoot stiffness, shoot size and current velocity on scouring sediment from around seedlings and propagules. Marine Ecology Progress Series 388, pp. 293-297. DOI:HTTPS://DOI.ORG/10.3354/MEPS08130.

Bouma, T., L. Van Duren, S Temmerman, T Claverie, A Blanco-Garcia, T Ysebaert, and P. Herman (2007). Spatial flow and sedimentation patterns within patches of epibenthic structures: Combining field, flume and modelling experiments. Continental Shelf Research 27.8, pp. 1020-1045. DOI:HTTPS: //DOI.ORG/10.1016/J.CSR.2005.12.019.

Bouma, T. et al. (2013). Organism traits determine the strength of scale-dependent bio-geomorphic feedbacks: a flume study on three intertidal plant species. Geomorphology 180, pp. 57-65. DOI:HTTPs: //DOI.ORG/10.1016/J.GEOMORPH.2012.09.005.

Bouma, T. et al. (2016). Short-term mudflat dynamics drive long-term cyclic salt marsh dynamics. Limnology and Oceanography 61.6, pp. 2261-2275.

Boyce, C. K. (2008). How green was Cooksonia? The importance of size in understanding the early evolution of physiology in the vascular plant lineage. Paleobiology 34.2, pp. 179-194.

Boyce, C. K. and J.-E. Lee (2017). Plant evolution and climate over geological timescales. Annual Review of Earth and Planetary Sciences 45, pp. 61-87.

Braat, L., T. v. Kessel, J. R. Leuven, and M. G. Kleinhans (2017). Effects of mud supply on large-scale estuary morphology and development over centuries to millennia. Earth Surface Dynamics 5.4, pp. 617-652. 
Braat, L., J. R. Leuven, I. R. Lokhorst, and M. G. Kleinhans (2019a). Effects of estuarine mudflat formation on tidal prism and large-scale morphology in experiments. Earth Surface Processes and Landforms 44.2, pp. 417-432.

Braat, L., W. M. van Dijk, H. J. Pierik, W. van de Lageweg, M. Z. Brückner, F. Wagner-Cremer, and M. G. Kleinhans (2019b). Tidal bar accretion by mudflat sedimentation. DoI:10.31223/OSF.IO/GQ9PT.

Bradley, G.-M., J. Redfern, D. Hodgetts, A. D. George, and G. D. Wach (2018). The applicability of modern tidal analogues to pre-vegetation paralic depositional models. Sedimentology 65.6, pp. 21712201.

Brown, J. H., J. F. Gillooly, A. P. Allen, V. M. Savage, and G. B. West (2004). Toward a metabolic theory of ecology. Ecology 85.7, pp. 1771-1789.

Brückner, M. Z., L. Braat, C. Schwarz, and M. G. Kleinhans (2020). What came first, mud or biostabilizers? Elucidating interacting effects in a coupled model of mud, saltmarsh, microphytobenthos and estuarine morphology. Water Resources Research.

Brückner, M. Z., C. Schwarz, W. M. van Dijk, M. van Oorschot, H. Douma, and M. G. Kleinhans (2019). Salt marsh establishment and eco-engineering effects in dynamic estuaries determined by species growth and mortality. Journal of Geophysical Research: Earth Surface.

Bryan, G. and W. Langston (1992). Bioavailability, accumulation and effects of heavy metals in sediments with special reference to United Kingdom estuaries: a review. Environmental pollution 76.2, pp. 89-131.

Cao, H., Z. Zhu, T. Balke, L. Zhang, and T. J. Bouma (2018). Effects of sediment disturbance regimes on Spartina seedling establishment: Implications for salt marsh creation and restoration. Limnology and Oceanography 63.2, pp. 647-659.

Cavanaugh, K. C., E. M. Dangremond, C. L. Doughty, A. P. Williams, J. D. Parker, M. A. Hayes, W. Rodriguez, and I. C. Feller (2019). Climate-driven regime shifts in a mangrove-salt marsh ecotone over the past 250 years. Proceedings of the National Academy of Sciences 116.43, pp. 21602-21608.

Chapman, V. J. (1964). Coastal vegetation. Pergamon Press, New York.

Chen, S., R. Torres, and M. A. Goñi (2016). The role of salt marsh structure in the distribution of surface sedimentary organic matter. Estuaries and coasts 39.1, pp. 108-122.

Chen, X., C. Zhang, D. Paterson, C. Thompson, I. Townend, Z Gong, Z Zhou, and Q Feng (2017). Hindered erosion: The biological mediation of noncohesive sediment behavior. Water Resources Research 53.6, pp. 4787-4801.

Chen, Y., F. Shi, J. T. Kirby, G. Wu, and B. Liang (2020). A computationally efficient subgrid model for coupled surface and groundwater flows. Coastal Engineering 157, p. 103665.

Cheng, N.-S. (2011). Representative roughness height of submerged vegetation. Water Resources Research 47.8 .

Christiansen, T, P. Wiberg, and T. Milligan (2000). Flow and sediment transport on a tidal salt marsh surface. Estuarine, Coastal and Shelf Science 50.3, pp. 315-331.

Church, J. A. et al. (2013). Climate change 2013: the physical science basis. Contribution of Working Group I to the Fifth Assessment Report of the Intergovernmental Panel on Climate Change. Sea level change, p. 1137.

Cleveringa, J. (2014). LTV - Veiligheid en Toegankelijkheid: Ecotopen in de Westerschelde (in Dutch). Tech. rep. International Marine \& Dredging Consultants, Deltares, Svasek Hydraulics BV and ARCADIS.

Coco, G., S. F. Thrush, M. O. Green, and J. E. Hewitt (2006). Feedbacks between bivalve density, flow, and suspended sediment concentration on patch stable states. Ecology 87.11, pp. 2862-2870.

Coco, G., Z. Zhou, B Van Maanen, M. Olabarrieta, R. Tinoco, and I. Townend (2013). Morphodynamics of tidal networks: advances and challenges. Marine Geology 346, pp. 1-16.

Cooper, A. (1982). The effects of salinity and waterlogging on the growth and cation uptake of salt marsh plants. New phytologist 90.2, pp. 263-275.

Corcoran, P. L. (2015). Benthic plastic debris in marine and fresh water environments. Environmental Science: Processes \& Impacts 17.8, pp. 1363-1369. 
Corenblit, D., E. Tabacchi, J. Steiger, and A. M. Gurnell (2007). Reciprocal interactions and adjustments between fluvial landforms and vegetation dynamics in river corridors: a review of complementary approaches. Earth-Science Reviews 84.1-2, pp. 56-86.

Corenblit, D. et al. (2011). Feedbacks between geomorphology and biota controlling Earth surface processes and landforms: a review of foundation concepts and current understandings. Earth-Science Reviews 106.3-4, pp. 307-331.

Corenblit, D. et al. (2015). Engineer pioneer plants respond to and affect geomorphic constraints similarly along water-terrestrial interfaces world-wide. Global Ecology and Biogeography 24.12, pp. $1363-$ 1376.

Costanza, R. et al. (1997). The value of the world's ecosystem services and natural capital. Nature 387.6630, pp. 253-260.

Cowles, H. C. (1911). The causes of vegetational cycles. Annals of the Association of American Geographers 1.1, pp. 3-20.

Cozzoli, F, T. Bouma, T Ysebaert, and P. Herman (2013). Application of non-linear quantile regression to macrozoobenthic species distribution modelling: comparing two contrasting basins. $\mathrm{Ma}$ rine Ecology Progress Series 475, pp. 119-133.

Cozzoli, F., T. J. Bouma, P. Ottolander, M. S. Lluch, T. Ysebaert, and P. M. Herman (2018). The combined influence of body size and density on cohesive sediment resuspension by bioturbators. Scientific reports 8.1, pp. 1-12.

Cozzoli, F., V. Gjoni, M. Del Pasqua, Z. Hu, T. Ysebaert, P. M. Herman, and T. J. Bouma (2019). A process based model of cohesive sediment resuspension under bioturbators' influence. Science of the total environment 670, pp. 18-30.

Cozzoli, F., S. Smolders, M. Eelkema, T. Ysebaert, V. Escaravage, S. Temmerman, P. Meire, P. M. Herman, and T. J. Bouma (2017). A modeling approach to assess coastal management effects on benthic habitat quality: A case study on coastal defense and navigability. Estuarine, Coastal and Shelf Science 184, pp. 67-82.

Crooks, J. A. (2002). Characterizing ecosystem-level consequences of biological invasions: the role of ecosystem engineers. Oikos 97.2 , pp. 153-166.

Daggers, T. D., J. C. Kromkamp, P. M. Herman, and D. Van Der Wal (2018). A model to assess microphytobenthic primary production in tidal systems using satellite remote sensing. Remote sensing of environment 211, pp. 129-145.

D’Alpaos, A. (2011). The mutual influence of biotic and abiotic components on the long-term ecomorphodynamic evolution of salt-marsh ecosystems. Geomorphology 126.3, pp. 269-278.

D’Alpaos, A., C. Da Lio, and M. Marani (2012). Biogeomorphology of tidal landforms: physical and biological processes shaping the tidal landscape. Ecohydrology 5.5, pp. 550-562.

D’Alpaos, A., S. Lanzoni, M. Marani, and A. Rinaldo (2007). Landscape evolution in tidal embayments: modeling the interplay of erosion, sedimentation, and vegetation dynamics. Journal of Geophysical Research: Earth Surface 112.F1.

D’Alpaos, A., S. Lanzoni, S. M. Mudd, and S. Fagherazzi (2006). Modeling the influence of hydroperiod and vegetation on the cross-sectional formation of tidal channels. Estuarine, Coastal and Shelf Science 69.3-4, pp. 311-324.

Dalrymple, R. W. and K. Choi (2007). Morphologic and facies trends through the fluvial-marine transition in tide-dominated depositional systems: a schematic framework for environmental and sequencestratigraphic interpretation. Earth-Science Reviews 81.3-4, pp. 135-174.

Dalrymple, R. W., D. A. Mackay, A. A. Ichaso, and K. S. Choi (2012). Processes, morphodynamics, and facies of tide-dominated estuaries. In: Principles of Tidal Sedimentology. Springer, pp. 79-107.

Dam, G, M Van der Wegen, R. Labeur, and D Roelvink (2016). Modeling centuries of estuarine morphodynamics in the Western Scheldt estuary. Geophysical Research Letters 43.8, pp. 3839-3847.

Davies, N. S. and M. R. Gibling (2010). Cambrian to Devonian evolution of alluvial systems: the sedimentological impact of the earliest land plants. Earth-Science Reviews 98.3-4, pp. 171-200. 
Davies, N. S. and M. R. Gibling (2013). The sedimentary record of Carboniferous rivers: continuing influence of land plant evolution on alluvial processes and Palaeozoic ecosystems. Earth-Science Reviews 120, pp. 40-79.

Davies, N. S. et al. (2017). Discussion on $\bigotimes$ Tectonic and environmental controls on Palaeozoic fluvial environments: reassessing the impacts of early land plants on sedimentation $\nabla$ Journal of the GeologicalSociety, London, https://doi. org/10.1144/jgs2016-063. Journal of the Geological Society 174.5, pp. 947-950.

Davis Jr, R. A. and M. O. Hayes (1984). What is a wave-dominated coast?. Marine geology 60.1-4, pp. 313-329.

Davy, A. J., G. F. Bishop, and C. S. B. Costa (2001). Salicornia L. (Salicornia pusilla J. woods, S. ramosissima J. woods, S. europaea L., S. obscura PW ball \& tutin, S. nitens PW ball \& tutin, S. fragilis PW ball \& tutin and S. dolichostachya moss). Journal of Ecology 89.4, pp. 681-707.

Day, J. W. J., J. D. Gunn, W. J. Folan, A. Yáñez-Arancibia, and B. P. Horton (2007). Emergence of complex societies after sea level stabilized. Eos, Transactions American Geophysical Union 88.15, pp. 169170.

Day, J. W. J., A. Yanez-Arancibia, W. M. Kemp, and B. C. Crump (2013). Introduction to estuarine ecology. Estuarine ecology 2, pp. 1-19.

De Jonge, V. N. (2000). Importance of temporal and spatial scales in applying biological and physical process knowledge in coastal management, an example for the Ems estuary. Continental Shelf Research 20.12-13, pp. 1655-1686.

De Backer, A., E. Van Ael, M. Vincx, and S. Degraer (2010). Behaviour and time allocation of the mud shrimp, Corophium volutator, during the tidal cycle: a laboratory study. Helgoland Marine Research 64.1, p. 63.

De Backer, A., F. Van Coillie, F. Montserrat, P. Provoost, C. Van Colen, M. Vincx, and S. Degraer (2011). Bioturbation effects of Corophium volutator: Importance of density and behavioural activity. Estuarine, Coastal and Shelf Science 91.2, pp. 306-313.

De Brouwer, J. and L. Stal (2001). Short-term dynamics in microphytobenthos distribution and associated extracellular carbohydrates in surface sediments of an intertidal mudflat. Marine Ecology Progress Series 218, pp. 33-44.

De Deckere, E., T. Tolhurst, and J. De Brouwer (2001). Destabilization of cohesive intertidal sediments by infauna. Estuarine, Coastal and Shelf Science 53.5, pp. 665-669.

De Groot, R. S., R. Alkemade, L. Braat, L. Hein, and L. Willemen (2010). Challenges in integrating the concept of ecosystem services and values in landscape planning, management and decision making. Ecological complexity 7.3, pp. 260-272.

De Haas, T, H. Pierik, A. Van der Spek, K. Cohen, B Van Maanen, and M. Kleinhans (2018). Holocene evolution of tidal systems in The Netherlands: Effects of rivers, coastal boundary conditions, ecoengineering species, inherited relief and human interference. Earth-Science Reviews 177, pp. 139163.

De Jorge, V. and J. Van Beusekom (1995). Wind-and tide-induced resuspension of sediment and microphytobenthos from tidal flats in the Ems estuary. Limnology and oceanography 40.4, pp. 776778.

De la Riva, E. G., O. Godoy, P. Castro-Díez, C. Gutiérrez-Cánovas, and M. Vilà (2019). Functional and phylogenetic consequences of plant invasion for coastal native communities. Journal of Vegetation Science 30.3, pp. 510-520.

De Vet, P., B. van Prooijen, and Z. Wang (2017). The differences in morphological development between the intertidal flats of the Eastern and Western Scheldt. Geomorphology 281, pp. 31-42.

De Vriend, H. J., Z. B. Wang, T. Ysebaert, P. M. Herman, and P. Ding (2011). Eco-morphological problems in the Yangtze Estuary and the Western Scheldt. Wetlands 31.6, pp. 1033-1042.

Dippner, J. W., K. Junker, and I. Kröncke (2010). Biological regime shifts and changes in predictability. Geophysical Research Letters 37.24. 
Dissanayake, N. G., C. L. Frid, T. P. Drylie, and B. A. Caswell (2018). Ecological functioning of mudflats: global analysis reveals both regional differences and widespread conservation of functioning. Marine Ecology Progress Series 604, pp. 1-20.

Do Sul, J. A. I. and M. F. Costa (2014). The present and future of microplastic pollution in the marine environment. Environmental pollution 185, pp. 352-364.

Dronkers, J (1986). Tidal asymmetry and estuarine morphology. Netherlands Journal of Sea Research 20.2-3, pp. 117-131.

Dunn, F. E., S. E. Darby, R. J. Nicholls, S. Cohen, C. Zarfl, and B. M. Fekete (2019). Projections of declining fluvial sediment delivery to major deltas worldwide in response to climate change and anthropogenic stress. Environmental Research Letters 14.8, p. 084034.

Duran-Matute, M. and T. Gerkema (2015). Calculating residual flows through a multiple-inlet system: the conundrum of the tidal period. Ocean Dynamics 65.11, pp. 1461-1475.

Dürr, H. H., G. G. Laruelle, C. M. van Kempen, C. P. Slomp, M. Meybeck, and H. Middelkoop (2011). Worldwide typology of nearshore coastal systems: defining the estuarine filter of river inputs to the oceans. Estuaries and Coasts 34.3, pp. 441-458.

Dyer, K., M. Christie, and E. Wright (2000). The classification of intertidal mudflats. Continental Shelf Research 20.10-11, pp. 1039-1060.

Edmonds, D. A. and R. L. Slingerland (2010). Significant effect of sediment cohesion on delta morphology. Nature Geoscience 3.2, p. 105.

Elick, J. M., S. G. Driese, and C. I. Mora (1998). Very large plant and root traces from the Early to Middle Devonian: Implications for early terrestrial ecosystems and atmospheric p (CO2). Geology 26.2, pp. 143-146.

Emerson, B. C. and N. Kolm (2005). Species diversity can drive speciation. Nature 434.7036, pp. 10151017.

Emmerson, M. (2000). Remedial habitat creation: does Nereis diversicolor play a confounding role in the colonisation and establishment of the pioneering saltmarsh plant, Spartina anglica?. Helgoland Marine Research 54.2-3, pp. 110-116.

Enders, K. et al. (2019). tracing microplastics in aquatic environments based on sediment analogies. Scientific reports 9.1 , pp. 1-15.

Engelund, F. and E. Hansen (1967). A monograph on sediment transport in alluvial streams. Technical University of Denmark 0stervoldgade 10, Copenhagen $K$.

Erchinger, H. (1985). Dünen, Watt und Salzwiesen. Das Niedersächsische Ministerium für Ernährung, Landwirtschaft und Forsten. Hannover.

Erwin, D. H. (2008). Macroevolution of ecosystem engineering, niche construction and diversity. Trends in ecology \& evolution 23.6, pp. 304-310.

Fagherazzi, S, G Mariotti, A. Banks, E. Morgan, and R. Fulweiler (2014). The relationships among hydrodynamics, sediment distribution, and chlorophyll in a mesotidal estuary. Estuarine, Coastal and Shelf Science 144, pp. 54-64.

Fagherazzi, S., M. Marani, L. K. Blum, et al. (2004). The ecogeomorphology of tidal marshes. American Geophysical Union.

Fagherazzi, S. and T. Sun (2004). A stochastic model for the formation of channel networks in tidal marshes. Geophysical Research Letters 31.21 .

Fagherazzi, S. et al. (2012). Numerical models of salt marsh evolution: Ecological, geomorphic, and climatic factors. Reviews of Geophysics 50.1.

Fairbridge, R. (1980). The estuary: its definition and geodynamic cycle. In: Chemistry and Biochemistry of Estuaries. Wiley, pp. 1-35.

Fang, X., S. Mestdagh, T. Ysebaert, T. Moens, K. Soetaert, and C. Van Colen (2019). Spatio-temporal variation in sediment ecosystem processes and roles of key biota in the Scheldt estuary. Estuarine, Coastal and Shelf Science 222, pp. 21-31. 
Feagin, R. A. et al. (2015). Going with the flow or against the grain? The promise of vegetation for protecting beaches, dunes, and barrier islands from erosion. Frontiers in Ecology and the Environment 13.4, pp. 203-210.

Fischer, W. W. (2018). Early plants and the rise of mud. Science 359.6379, pp. 994-995.

FitzGerald, D. M. and Z. Hughes (2019). Marsh Processes and Their Response to Climate Change and Sea-Level Rise. Annual Review of Earth and Planetary Sciences 47.

French, J. R. and T. Spencer (1993). Dynamics of sedimentation in a tide-dominated backbarrier salt marsh, Norfolk, UK. Marine Geology 110.3-4, pp. 315-331.

Friedrichs, C. T. and D. G. Aubrey (1988). Non-linear tidal distortion in shallow well-mixed estuaries: a synthesis. Estuarine, Coastal and Shelf Science 27.5, pp. 521-545.

Friedrichs, C. T. and J. E. Perry (2001). Tidal salt marsh morphodynamics: a synthesis. Journal of Coastal Research, pp. 7-37.

Friedrichs, M., G. Graf, and B. Springer (2000). Skimming flow induced over a simulated polychaete tube lawn at low population densities. Marine ecology progress series 192, pp. 219-228.

Friend, P., P. Ciavola, S Cappucci, and R Santos (2003). Bio-dependent bed parameters as a proxy tool for sediment stability in mixed habitat intertidal areas. Continental Shelf Research 23.17-19, pp. 18991917.

Fujii, T (2007). Spatial patterns of benthic macrofauna in relation to environmental variables in an intertidal habitat in the Humber estuary, UK: Developing a tool for estuarine shoreline management. Estuarine, Coastal and Shelf Science 75.1-2, pp. 101-119.

Fujii, T. and D. Raffaelli (2008). Sea-level rise, expected environmental changes, and responses of intertidal benthic macrofauna in the Humber estuary, UK. Marine Ecology Progress Series 371, pp. 23 35.

Gensel, P. G. (2008). The earliest land plants. Annual Review of Ecology, Evolution, and Systematics 39, pp. 459-477.

Gensel, P. G. and C. M. Berry (2001). Early lycophyte evolution. American Fern Journal 91.3, pp. 74-98.

Gensel, P. G., M. E. Kotyk, and J. F. Basinger (2001). Morphology ofAbove-and Below-Ground Structures in Early Devonian (Pragian-Emsian) Plants. Plants invade the land: evolutionary and environmental perspectives, p. 83.

Gibling, M. R. and N. S. Davies (2012). Palaeozoic landscapes shaped by plant evolution. Nature Geoscience 5.2, pp. 99-105.

Gill, J. A., K. Norris, P. M. Potts, T. G. Gunnarsson, P. W. Atkinson, and W. J. Sutherland (2001). The buffer effect and large-scale population regulation in migratory birds. Nature 412.6845 , p. 436.

Gourgue, O., J. van Belzen, C. Schwarz, T. J. Bouma, J. van de Koppel, and S. Temmerman (2020). A convolution method to assess subgrid-scale interactions between flow and patchy vegetation in biogeomorphic models. Journal of Advances in Modeling Earth Systems.

Graham, J. R., C. N. Bhroin, and G. D. Sevastopulo (2014). The Carboniferous geology of northern Donegal Bay. Irish Journal of Earth Sciences 32, pp. 29-54.

Grasmeijer, B, G Dam, and M Taal (2013). Actualisatierapport Delft3D Schelde estuarium (in Dutch). International Marine \& Dredging Consultants.

Gray, A. (1992). Saltmarsh plant ecology: zonation and succession revisited. Saltmarshes: morphodynamics, conservation and engineering significance. Cambridge University Press, Cambridge, pp. 6379.

Gray, A. and R. Bunce (1972). The ecology of Morecambe Bay. VI. Soils and vegetation of the salt marshes: a multivariate approach. Journal of applied Ecology, pp. 221-234.

Gray, A. and R. Scott (1977). The ecology of Morecambe Bay. VII. The distribution of Puccinellia maritima, Festuca rubra and Agrostis stolonifera in the salt marshes. Journal of Applied Ecology, pp. 229-241.

Gray, A. J., D. Marshall, and A. Raybould (1991). A century of evolution in Spartina anglica. In: Advances in ecological research. Vol. 21. Elsevier, pp. 1-62. 
Gray, A. J. and R. J. Mogg (2001). Climate impacts on pioneer saltmarsh plants. Climate Research 18.1-2, pp. 105-112.

Hale, S. S., H. W. Buffum, and M. M. Hughes (2018). Six decades of change in pollution and benthic invertebrate biodiversity in a southern New England estuary. Marine pollution bulletin 133, pp. $77-$ 87.

Hazen, R. M., D. A. Sverjensky, D. Azzolini, D. L. Bish, S. C. Elmore, L. Hinnov, and R. E. Milliken (2013). Clay mineral evolution. American Mineralogist 98.11-12, pp. 2007-2029.

Heck, K. L., T. J. Carruthers, C. M. Duarte, A. R. Hughes, G. Kendrick, R. J. Orth, and S. W. Williams (2008). Trophic transfers from seagrass meadows subsidize diverse marine and terrestrial consumers. Ecosystems 11.7, pp. 1198-1210.

Heip, C. and P. M. Herman (1995). Major biological processes in European tidal estuaries: a synthesis of the JEEP-92 Project.

Heip, C., N. Goosen, P. Herman, J. Kromkamp, J. Middelburg, and K. Soetaert (1995). Production and consumption of biological particles in temperate tidal estuaries. Oceanography and Marine Biology: an annual review 33, pp. 1-149.

Herman, P. M., J. J. Middelburg, and C. H. Heip (2001). Benthic community structure and sediment processes on an intertidal flat: results from the ECOFLAT project. Continental shelf research 21.18 19, pp. 2055-2071.

Higinbotham, C. B., M. Alber, and A. G. Chalmers (2004). Analysis of tidal marsh vegetation patterns in two Georgia estuaries using aerial photography and GIS. Estuaries 27.4, pp. 670-683.

Hitchcock, J. N. and S. M. Mitrovic (2019). Microplastic pollution in estuaries across a gradient of human impact. Environmental Pollution 247, pp. 457-466.

Holling, C. (1973). Resilience and stability of ecological systems. Annual Review of Ecology and Systematics 4 , p. 23.

Hooper, D. U. et al. (2005). Effects of biodiversity on ecosystem functioning: a consensus of current knowledge. Ecological monographs 75.1, pp. 3-35.

Hope, J. A., G. Coco, and S. F. Thrush (2020). The effects of polyester microfibers on microphytobenthos and sediment-dwelling infauna. Environmental Science \& Technology.

Hu, Z., D. Van Der Wal, H. Cai, J. Van Belzen, and T. J. Bouma (2018). Dynamic equilibrium behaviour observed on two contrasting tidal flats from daily monitoring of bed-level changes. Geomorphology 311, pp. 114-126.

Huckle, J. M., J. A. Potter, and R. H. Marrs (2000). Influence of environmental factors on the growth and interactions between salt marsh plants: effects of salinity, sediment and waterlogging. Journal of Ecology 88.3, pp. 492-505.

Hughes, A. L., A. M. Wilson, and J. T. Morris (2012). Hydrologic variability in a salt marsh: Assessing the links between drought and acute marsh dieback. Estuarine, Coastal and Shelf Science 111, pp. 95 106.

Hughes, C., J. Kalma, P Binning, G. Willgoose, and M Vertzonis (2001). Estimating evapotranspiration for a temperate salt marsh, Newcastle, Australia. Hydrological Processes 15.6, pp. 957-975.

Hughes, R. (1999). Saltmarsh erosion and management of saltmarsh restoration; the effects of infaunal invertebrates. Aquatic conservation: marine and freshwater ecosystems 9.1, pp. 83-95.

Hughes, R. (2004). Climate change and loss of saltmarshes: consequences for birds. Ibis 146, pp. 21-28.

Humphreys, J., M. R. C. Harris, R. J. H. Herbert, P. Farrell, A. Jensen, and S. M. Cragg (2015). Introduction, dispersal and naturalization of the Manila clam Ruditapes philippinarum in British estuaries, 1980-2010. English. Journal of the Marine Biological Association of the United Kingdom 95.6. Cited By : 18 , pp. 1163-1172.

Hydraulics, D. (2006). Delft3D-FLOW: Simulation of Multidimensional Hydrodynamic Flows and Transport Phenomena, including Sediments, User Manual. Delft, Holland: Deltares.

Ibañez, C., J. W. Day Jr, and D. Pont (1999). Primary production and decomposition of wetlands of the Rhone Delta, France: Interactive impacts of human modifications and relative sea level rise. Journal of Coastal Research, pp. 717-731. 
Ibáñez, C., J. T. Morris, I. A. Mendelssohn, and J. W. Day (2012). Coastal marshes. Estuarine Ecology, Second Edition, pp. 129-163.

Ides, S. J., Y Plancke, and J. Peters (2007). A new approach for managing the Western Scheldt's morphology and ecology. In: IAHR 32th Congress, Venice, Italy. Vol. 1, p. 233.

Jefferies, R., A. J. Davy, and T Rudmik (1981). Population biology of the salt marsh annual Salicornia europaea agg.. The Journal of Ecology, pp. 17-31.

Jones, C. G., J. H. Lawton, and M. Shachak (1994). Organisms as ecosystem engineers. In: Ecosystem management. Springer, pp. 130-147.

Jones, C. G., J. H. Lawton, and M. Shachak (1997). Positive and negative effects of organisms as physical ecosystem engineers. Ecology 78.7, pp. 1946-1957.

Kane, I. A. and M. A. Clare (2019). Dispersion, accumulation, and the ultimate fate of microplastics in deep-marine environments: A review and future directions. Frontiers in Earth Science 7, p. 80.

Kearney, W. S. and S. Fagherazzi (2016). Salt marsh vegetation promotes efficient tidal channel networks. Nature communications 7.1, pp. 1-7.

Kelly, A. E. and M. L. Goulden (2008). Rapid shifts in plant distribution with recent climate change. Proceedings of the National Academy of Sciences 105.33, pp. 11823-11826.

Kennett, D. J. and J. P. Kennett (2006). Early state formation in southern Mesopotamia: Sea levels, shorelines, and climate change. Journal of Island \& Coastal Archaeology 1.1, pp. 67-99.

Kennish, M. J. (2002). Environmental threats and environmental future of estuaries. Environmental conservation, pp. 78-107.

Kenrick, P. and P. R. Crane (1997). The origin and early evolution of plants on land. Nature 389.6646, pp. 33-39.

Kenrick, P., C. H. Wellman, H. Schneider, and G. D. Edgecombe (2012). A timeline for terrestrialization: consequences for the carbon cycle in the Palaeozoic. Philosophical Transactions of the Royal Society B: Biological Sciences 367.1588, pp. 519-536.

Kirwan, M. L., G. R. Guntenspergen, A. d'Alpaos, J. T. Morris, S. M. Mudd, and S. Temmerman (2010). Limits on the adaptability of coastal marshes to rising sea level. Geophysical research letters 37.23.

Kirwan, M. L. and J. P. Megonigal (2013). Tidal wetland stability in the face of human impacts and sea-level rise. Nature 504.7478, pp. 53-60.

Kirwan, M. L. and A. B. Murray (2007). A coupled geomorphic and ecological model of tidal marsh evolution. Proceedings of the National Academy of Sciences 104.15, pp. 6118-6122.

Kirwan, M. L., S. Temmerman, E. E. Skeehan, G. R. Guntenspergen, and S. Fagherazzi (2016). Overestimation of marsh vulnerability to sea level rise. Nature Climate Change 6.3, pp. 253-260.

Kleinhans, M. G. (2010). Sorting out river channel patterns. Progress in physical geography 34.3, pp. 287 326.

Kleinhans, M. G., B. de Vries, L. Braat, and M. van Oorschot (2018). Living landscapes: Muddy and vegetated floodplain effects on fluvial pattern in an incised river. Earth surface processes and landforms 43.14, pp. 2948-2963.

Knaapen, M., H. Holzhauer, S. Hulscher, M. Baptist, M. De Vries, and M Van Ledden (2003). On the modelling of biological effects on morphology in estuaries and seas. In: Proceedings of the Third IAHR Symposium on River, Coastal and Estuarine Morphodynamics Conference. IAHR, Barcelona, Spain, pp. 773-783.

Kristensen, E., M. Delefosse, C. O. Quintana, M. R. Flindt, and T. Valdemarsen (2014). Influence of benthic macrofauna community shifts on ecosystem functioning in shallow estuaries. Frontiers in Marine Science 1, p. 41.

Kristensen, E., T. Hansen, M. Delefosse, G. T. Banta, and C. O. Quintana (2011). Contrasting effects of the polychaetes Marenzelleria viridis and Nereis diversicolor on benthic metabolism and solute transport in sandy coastal sediment. Marine Ecology Progress Series 425, pp. 125-139.

Kröncke, I., H. Reiss, and J. W. Dippner (2013). Effects of cold winters and regime shifts on macrofauna communities in shallow coastal regions. Estuarine, Coastal and Shelf Science 119, pp. 79-90. 
Langlois, E, A Bonis, and J. Bouzillé (2003). Sediment and plant dynamics in saltmarshes pioneer zone: Puccinellia maritima as a key species?. Estuarine, Coastal and Shelf Science 56.2, pp. 239-249.

Lawrie, S. and D. Raffaelli (1998). Activity and mobility of Corophium volutator: a field study. Marine \& Freshwater Behaviour \& Phy 31.1, pp. 39-53.

Le Hir, P, Y Monbet, and F Orvain (2007). Sediment erodability in sediment transport modelling: can we account for biota effects?. Continental Shelf Research 27.8, pp. 1116-1142.

Lenoir, J., J.-C. Gégout, P. Marquet, P De Ruffray, and H Brisse (2008). A significant upward shift in plant species optimum elevation during the 20th century. science 320.5884, pp. 1768-1771.

Leonard, L. A. and M. E. Luther (1995). Flow hydrodynamics in tidal marsh canopies. Limnology and oceanography 40.8, pp. 1474-1484.

Leonardi, N., I. Carnacina, C. Donatelli, N. K. Ganju, A. J. Plater, M. Schuerch, and S. Temmerman (2018). Dynamic interactions between coastal storms and salt marshes: A review. Geomorphology 301, pp. 92-107.

Leonardi, N., N. K. Ganju, and S. Fagherazzi (2016). A linear relationship between wave power and erosion determines salt-marsh resilience to violent storms and hurricanes. Proceedings of the National Academy of Sciences 113.1, pp. 64-68.

Lesser, G., J. v. Roelvink, J. Van Kester, and G. Stelling (2004). Development and validation of a threedimensional morphological model. Coastal engineering 51.8-9, pp. 883-915.

Leuven, J. R., L. Braat, W. M. van Dijk, T. de Haas, E. van Onselen, B. Ruessink, and M. G. Kleinhans (2018a). Growing forced bars determine nonideal estuary planform. Journal of Geophysical Research: Earth Surface 123.11, pp. 2971-2992.

Leuven, J. R., H. J. Pierik, M. van der Vegt, T. J. Bouma, and M. G. Kleinhans (2019). Sea-level-riseinduced threats depend on the size of tide-influenced estuaries worldwide. Nature Climate Change 9.12, pp. 986-992.

Leuven, J., T De Haas, L Braat, and M. Kleinhans (2018b). Topographic forcing of tidal sandbar patterns for irregular estuary planforms. Earth Surface Processes and Landforms 43.1, pp. 172-186.

Leys, E, Y Plancke, and S Ides (2006). Shallow-shallower-shallowest: morphological monitoring Walsoorden.

Li, B., F. Cozzoli, L. M. Soissons, T. J. Bouma, and L. Chen (2017). Effects of bioturbation on the erodibility of cohesive versus non-cohesive sediments along a current-velocity gradient: A case study on cockles. Journal of Experimental Marine Biology and Ecology 496, pp. 84-90.

Loebl, M., J. E. van Beusekom, and K. Reise (2006). Is spread of the neophyte Spartina anglica recently enhanced by increasing temperatures?. Aquatic Ecology 40.3, pp. 315-324.

Lohrer, A., N. Halliday, S. Thrush, J. Hewitt, and I. Rodil (2010). Ecosystem functioning in a disturbancerecovery context: contribution of macrofauna to primary production and nutrient release on intertidal sandflats. Journal of Experimental Marine Biology and Ecology 390.1, pp. 6-13.

Lohrer, A. M., S. F. Thrush, and M. M. Gibbs (2004). Bioturbators enhance ecosystem function through complex biogeochemical interactions. Nature 431.7012, pp. 1092-1095.

Lokhorst, I, L Braat, J. Leuven, A. Baar, M van Oorschot, S Selakovic, and M. Kleinhans (2018). Morphological effects of vegetation on the fluvial-tidal transition in holocene estuaries. Earth Surface Dynamics Discussions 2018, pp. 1-28.

Long, D. G. (2019). Archean fluvial deposits: A review. Earth-Science Reviews 188, pp. 148-175.

Long, D. (2011). Architecture and depositional style of fluvial systems before land plants: a comparison of Precambrian, early Paleozoic and modern river deposits. From river to rock record: The preservation of fluvial sediments and their subsequent interpretation 97, pp. 37-61.

Lu, M., Y. Lu, T. Ikejiri, N. Hogancamp, Y. Sun, Q. Wu, R. Carroll, I. Çemen, and J. Pashin (2019). Geochemical evidence of First Forestation in the southernmost euramerica from Upper Devonian (Famennian) Black shales. Scientific reports 9.1, pp. 1-15.

Lucas, C. H., J. Widdows, and L. Wall (2003). Relating spatial and temporal variability in sediment chlorophylla and carbohydrate distribution with erodibility of a tidal flat. Estuaries 26.4, pp. 885893. 
Maes, T. et al. (2018). Below the surface: Twenty-five years of seafloor litter monitoring in coastal seas of North West Europe (1992-2017). Science of The Total Environment 630, pp. 790-798.

Malarkey, J. et al. (2015). The pervasive role of biological cohesion in bedform development. Nature communications 6, p. 6257.

Marani, M., E. Belluco, A. D’Alpaos, A. Defina, S. Lanzoni, and A. Rinaldo (2003). On the drainage density of tidal networks. Water Resources Research 39.2.

Marani, M., A. D'Alpaos, S. Lanzoni, L. Carniello, and A. Rinaldo (2010). The importance of being coupled: Stable states and catastrophic shifts in tidal biomorphodynamics. Journal of Geophysical Research: Earth Surface 115.F4.

Marani, M., S. Lanzoni, D. Zandolin, G. Seminara, and A. Rinaldo (2002). Tidal meanders. Water Resources Research 38.11, pp. 7-1.

Marciano, R., Z. B. Wang, A. Hibma, H. J. de Vriend, and A. Defina (2005). Modeling of channel patterns in short tidal basins. Journal of Geophysical Research: Earth Surface 110.F1.

Mariotti, G. and A. Canestrelli (2017). Long-term morphodynamics of muddy backbarrier basins: Fill in or empty out?. Water Resources Research 53.8, pp. 7029-7054.

Mariotti, G. and S. Fagherazzi (2010). A numerical model for the coupled long-term evolution of salt marshes and tidal flats. Journal of Geophysical Research: Earth Surface 115.F1.

Marker, M. E. (1967). The Dee estuary: its progressive silting and salt marsh development. Transactions of the Institute of British Geographers, pp. 65-71.

Mathot, K. J., T. Piersma, and R. W. Elner (2018). Shorebirds as integrators and indicators of mudflat ecology. In: Mudflat ecology. Springer, pp. 309-338.

Matsunaga, K. K. and A. M. Tomescu (2016). Root evolution at the base of the lycophyte clade: insights from an Early Devonian lycophyte. Annals of botany 117.4, pp. 585-598.

Maximova, T, S Ides, T De Mulder, and F Mostaert (2009a). LTV O \& $M$ thema Veiligheid - Deelproject 1: Verbetering hydrodynamisch NeVla model ten behoeve van scenario-analyse (in Dutch).

Maximova, T, S Ides, J Vanlede, T De Mulder, and F Mostaert (2009b). Verbetering 2D randvoorwaardenmodel. Deelrapport 3: kalibratie bovenlopen (in Dutch).

Mcleod, E., G. L. Chmura, S. Bouillon, R. Salm, M. Björk, C. M. Duarte, C. E. Lovelock, W. H. Schlesinger, and B. R. Silliman (2011). A blueprint for blue carbon: toward an improved understanding of the role of vegetated coastal habitats in sequestering CO2. Frontiers in Ecology and the Environment 9.10, pp. 552-560.

McMahon, W. J. and N. S. Davies (2018). Evolution of alluvial mudrock forced by early land plants. Science 359.6379, pp. 1022-1024.

McMahon, W. J. and N. S. Davies (2020). Physical and biological functioning in Proterozoic rivers: evidence from the archetypal pre-vegetation alluvium of the Torridon Group, NW Scotland. Scottish Journal of Geology 56.1, pp. 1-29.

Meire, P., T. Ysebaert, S. Van Damme, E. Van den Bergh, T. Maris, and E. Struyf (2005). The Scheldt estuary: a description of a changing ecosystem. Hydrobiologia 540.1-3, pp. 1-11.

Mendelssohn, I. A. and J. T. Morris (2002). Eco-physiological controls on the productivity of Spartina alterniflora Loisel. Concepts and controversies in tidal marsh ecology, pp. 59-80.

Meyer-Berthaud, B., A.-L. Decombeix, and X. Ermacora (2013). Archaeopterid root anatomy and architecture: new information from permineralized specimens of Famennian age from Anti-Atlas (Morocco). International Journal of Plant Sciences 174.3, pp. 364-381.

Meysman, F. J., J. J. Middelburg, and C. H. Heip (2006). Bioturbation: a fresh look at Darwin's last idea. Trends in Ecology \& Evolution 21.12, pp. 688-695.

Miller, C. D. (1987). Predicting the impact of vegetation on storm surges. Wetland Hydrology 113.

Miller, R. C. and J. B. Zedler (2003). Responses of native and invasive wetland plants to hydroperiod and water depth. Plant ecology 167.1, pp. 57-69.

Mitchener, H. and H. Torfs (1996). Erosion of mud/sand mixtures. Coastal engineering 29.1-2, pp. 125. 
Möller, I. et al. (2014). Wave attenuation over coastal salt marshes under storm surge conditions. Nature Geoscience 7.10, pp. 727-731.

Montserrat, F., C. Van Colen, S. Degraer, T. Ysebaert, and P. M. Herman (2008). Benthic communitymediated sediment dynamics. Marine ecology progress series 372, pp. 43-59.

Moor, H., H. Rydin, K. Hylander, M. B. Nilsson, R. Lindborg, and J. Norberg (2017). Towards a traitbased ecology of wetland vegetation. Journal of Ecology 105.6, pp. 1623-1635.

Moore, R. D., J. Wolf, A. J. Souza, and S. S. Flint (2009). Morphological evolution of the Dee Estuary, Eastern Irish Sea, UK: a tidal asymmetry approach. Geomorphology 103.4, pp. 588-596.

Morris, J. T. (2006). Competition among marsh macrophytes by means of geomorphological displacement in the intertidal zone. Estuarine, Coastal and Shelf Science 69.3, pp. 395-402.

Morris, J. T., J. Edwards, S. Crooks, and E. Reyes (2012). Assessment of carbon sequestration potential in coastal wetlands. In: Recarbonization of the biosphere. Springer, pp. 517-531.

Morris, J. T. and B. Haskin (1990). A 5-yr record of aerial primary production and stand characteristics of Spartina alterniflora. Ecology 71.6, pp. 2209-2217.

Morris, J. T., P. Sundareshwar, C. T. Nietch, B. Kjerfve, and D. R. Cahoon (2002). Responses of coastal wetlands to rising sea level. Ecology 83.10, pp. 2869-2877.

Mudd, S. M., S. M. Howell, and J. T. Morris (2009). Impact of dynamic feedbacks between sedimentation, sea-level rise, and biomass production on near-surface marsh stratigraphy and carbon accumulation. Estuarine, Coastal and Shelf Science 82.3, pp. 377-389.

Mudd, S. M., S. Fagherazzi, J. T. Morris, and D. J. Furbish (2004). Flow, sedimentation, and biomass production on a vegetated salt marsh in South Carolina: toward a predictive model of marsh morphologic and ecologic evolution. The ecogeomorphology of tidal marshes, pp. 165-188.

Muhlbauer, J. G. and C. M. Fedo (2020). Architecture of a river-dominated, wave-and tide-influenced, pre-vegetation braid delta: Cambrian middle member of the Wood Canyon Formation, southern Marble Mountains, California, USA. Journal of Sedimentary Research 90.9, pp. 1011-1036.

Murray, A., M. Knaapen, M Tal, and M. Kirwan (2008). Biomorphodynamics: Physical-biological feedbacks that shape landscapes. Water Resources Research 44.11.

Murray, J. M., A. Meadows, and P. S. Meadows (2002). Biogeomorphological implications of microscale interactions between sediment geotechnics and marine benthos: a review. Geomorphology 47.1, pp. 15-30.

Nehring, S. and K.-J. Hesse (2008). Invasive alien plants in marine protected areas: the Spartina anglica affair in the European Wadden Sea. Biological Invasions 10.6, pp. 937-950.

Nepf, H. (1999). Drag, turbulence, and diffusion in flow through emergent vegetation. Water resources research 35.2 , pp. $479-489$.

Neumeier, U. and P. Ciavola (2004). Flow resistance and associated sedimentary processes in a Spartina maritima salt-marsh. Journal of Coastal Research, pp. 435-447.

Nichols, M. M. (1977). Response and recovery of an estuary following a river flood. Journal of Sedimentary Research 47.3, pp. 1171-1186.

Noffke, N., K. A. Eriksson, R. M. Hazen, and E. L. Simpson (2006). A new window into Early Archean life: Microbial mats in Earth's oldest siliciclastic tidal deposits (3.2 Ga Moodies Group, South Africa). Geology 34.4, pp. 253-256.

Obst, M. et al. (2018). Marine long-term biodiversity assessment suggests loss of rare species in the Skagerrak and Kattegat region. Marine Biodiversity 48.4, pp. 2165-2176.

Odum, E. P. and G. W. Barrett (1971). Fundamentals of ecology. Vol. 3. Saunders Philadelphia.

Olabarrieta, M., W. R. Geyer, G. Coco, C. T. Friedrichs, and Z. Cao (2018). Effects of density-driven flows on the long-term morphodynamic evolution of funnel-shaped estuaries. Journal of Geophysical Research: Earth Surface 123.11, pp. 2901-2924.

Orvain, F., P. Le Hir, P.-G. Sauriau, and S. Lefebvre (2012a). Modelling the effects of macrofauna on sediment transport and bed elevation: Application over a cross-shore mudflat profile and model validation. Estuarine, Coastal and Shelf Science 108, pp. 64-75. 
Orvain, F., S. Lefebvre, J Montepini, M Sébire, A. Gangnery, and B Sylvand (2012b). Spatial and temporal interaction between sediment and microphytobenthos in a temperate estuarine macro-intertidal bay. Marine Ecology Progress Series 458, pp. 53-68.

Paarlberg, A. J., M. A. Knaapen, M. B. de Vries, S. J. Hulscher, and Z. Wang (2005). Biological influences on morphology and bed composition of an intertidal flat. Estuarine, Coastal and Shelf Science 64.4, pp. $577-590$.

Partheniades, E. (1965). Erosion and deposition of cohesive soils. Journal of the Hydraulics Division 91.1, pp. 105-139.

Paterson, D. (1994). Biological mediation of sediment erodibility: ecology and physical dynamics. Burt, Neville; Parker, R. and Watts, Jacqueline H. eds. (1997) Cohesive sediments.

Pawlik, Ł., B. Buma, P. Šamonil, J. Kvaček, A. Gałązka, P. Kohout, and I. Malik (2020). Impact of trees and forests on the Devonian landscape and weathering processes with implications to the global Earth's system properties-A critical review. Earth-Science Reviews, p. 103200.

Pearson, P. N. (1992). Walking traces of the giant myriapod Arthropleura from the Strathclyde Group (Lower Carboniferous) of Fife. Scottish Journal of Geology 28.2, pp. 127-133.

Pennings, S. C. and R. M. Callaway (1992). Salt marsh plant zonation: the relative importance of competition and physical factors. Ecology 73.2, pp. 681-690.

Perona, P et al. (2012). Biomass selection by floods and related timescales: Part 1. Experimental observations. Advances in Water Resources 39, pp. 85-96.

Pillay, D, G. Branch, and A. Forbes (2008). Habitat change in an estuarine embayment: anthropogenic influences and a regime shift in biotic interactions. Marine Ecology Progress Series 370, pp. 19-31.

Plancke, Y, M Schrijver, D Meire, and F Mostaert (2017). Overleg Flexibel Storten: Deelrapport 22 Analyse van de waterbeweging, het sedimenttransport en de morfologie nabij de Plaat van Walsoorden (in Dutch). Versie 3.0. WL Rapporten 00_031_22. Waterbouwkundig Laboratorium: Antwerpen \& Rijkswaterstaat Zee \& Delta: Middelburg.

Plancke, Y., G. Vos, and T Ysebaert (2010). Analysis of multibeam echo sounding data on bed forms near the Walsoorden sandbar, a first phase in the subtidal habitat classification for the Western Scheldt. In: River Flow 2010 - Dittrich, Koll, Aberle \& Geisenhainer (eds).

Poppema, D. W., P. W. J. M. Willemsen, M. De Vries, Z Zhu, B. W. Borsje, and S. J. Hulscher (2017). Experiment-supported modeling of salt marsh establishment: Applying the Windows of opportunity concept to the Marconi pioneer salt marsh design. In: ECSA Focus Meeting 2017: Where Land Meets Ocean: The Vulnerable Interface.

Power, M. E. et al. (1996). Challenges in the quest for keystones: identifying keystone species is difficult but essential to understanding how loss of species will affect ecosystems. BioScience 46.8, pp. 609620.

Pratt, D. R., C. A. Pilditch, A. M. Lohrer, and S. F. Thrush (2014). The effects of short-term increases in turbidity on sandflat microphytobenthic productivity and nutrient fluxes. Journal of sea research 92, pp. 170-177.

Proffitt, C. E., R. L. Chiasson, A. B. Owens, K. R. Edwards, and S. E. Travis (2005). Spartina alterniflora genotype influences facilitation and suppression of high marsh species colonizing an early successional salt marsh. Journal of Ecology, pp. 404-416.

Ranasinghe, R., C. Swinkels, A. Luijendijk, D. Roelvink, J. Bosboom, M. Stive, and D. Walstra (2011). Morphodynamic upscaling with the MORFAC approach: Dependencies and sensitivities. Coastal engineering 58.8 , pp. 806-811.

Reed, D., B. van Wesenbeeck, P. M. Herman, and E. Meselhe (2018). Tidal flat-wetland systems as flood defenses: Understanding biogeomorphic controls. Estuarine, Coastal and Shelf Science 213, pp. 269-282.

Reed, D. J. (1990). The impact of sea-level rise on coastal salt marshes. Progress in Physical Geography 14.4, pp. 465-481. 
Reijers, V. C., P. M. Cruijsen, S. C. Hoetjes, M. van den Akker, J. H. Heusinkveld, J. van de Koppel, L. P. Lamers, H. Olff, and T. van der Heide (2019). Loss of spatial structure after temporary herbivore absence in a high-productivity reed marsh. Journal of Applied Ecology 56.7, pp. 1817-1826.

Reise, K., E. Herre, and M. Sturm (2007). Mudflat biota since the 1930s: change beyond return?. Helgoland Marine Research 62.1, p. 13. DoI:10.1007/s10152-007-0087-2.

Riethmüller, R, M Heineke, H Kühl, and R Keuker-Rüdiger (2000). Chlorophyll a concentration as an index of sediment surface stabilisation by microphytobenthos?. Continental Shelf Research 20.1011, pp. 1351-1372.

Ripley, B. (1977). Modelling spatial patterns (with discussion). JR Statist. Soc. B 39,172-212. Ripley17239J. R. Statist. Soc B 1977.

Roberts, W, P Le Hir, and R. Whitehouse (2000). Investigation using simple mathematical models of the effect of tidal currents and waves on the profile shape of intertidal mudflats. Continental Shelf Research 20.10-11, pp. 1079-1097.

Robinson, C. T., U. Uehlinger, and M. T. Monaghan (2003). Effects of a multi-year experimental flood regime on macroinvertebrates downstream of a reservoir. Aquatic Sciences 65.3, pp. 210-222.

Rodríguez, J. F., P. M. Saco, S. Sandi, N. Saintilan, and G. Riccardi (2017). Potential increase in coastal wetland vulnerability to sea-level rise suggested by considering hydrodynamic attenuation effects. Nature communications 8, p. 16094.

Roelvink, J. (2006). Coastal morphodynamic evolution techniques. Coastal engineering 53.2-3, pp. 277287.

Rubinstein, C. V., P. Gerrienne, G. S. de la Puente, R. A. Astini, and P. Steemans (2010). Early Middle Ordovician evidence for land plants in Argentina (eastern Gondwana). New Phytologist 188.2, pp. 365-369.

Sánchez-Baracaldo, P., J. A. Raven, D. Pisani, and A. H. Knoll (2017). Early photosynthetic eukaryotes inhabited low-salinity habitats. Proceedings of the National Academy of Sciences 114.37, E7737E7745.

Sanderson, E. W., S. L. Ustin, and T. C. Foin (2000). The influence of tidal channels on the distribution of salt marsh plant species in Petaluma Marsh, CA, USA. Plant Ecology 146.1, pp. 29-41.

Santoro, R., T. Jucker, M. Carboni, and A. T. Acosta (2012). Patterns of plant community assembly in invaded and non-invaded communities along a natural environmental gradient. Journal of Vegetation Science 23.3, pp. 483-494.

Santos, M. G., N. P. Mountney, J. Peakall, R. E. Thomas, P. B. Wignall, and D. M. Hodgson (2017). Reply to Discussion on "Tectonic and environmental controls on Palaeozoic fluvial environments: reassessing the impacts of early land plants on sedimentation" Journal of the Geological Society, London, https://doi. org/10.1144/jgs2016-063. Journal of the Geological Society 174.5, pp. 950-952.

Savage, C., S. F. Thrush, A. M. Lohrer, and J. E. Hewitt (2012). Ecosystem services transcend boundaries: estuaries provide resource subsidies and influence functional diversity in coastal benthic communities. PLoS One 7.8, e42708.

Savenije, H. H. (2005). Salinity and tides in alluvial estuaries. Elsevier, 194 pp.

Scholten, M and J Rozema (1990). The competitive ability of Spartina anglica on Dutch salt marshes. Spartina anglica-a research review, pp. 39-47.

Schrijvershof, R and J Vroom (2016). Effecten van realistische (extreme) stortstrategieën in de Westerschelde (in Dutch).

Schuerch, M., T. Dolch, K. Reise, and A. T. Vafeidis (2014). Unravelling interactions between salt marsh evolution and sedimentary processes in the Wadden Sea (southeastern North Sea). Progress in Physical Geography 38.6, pp. 691-715.

Schuerch, M. et al. (2018). Future response of global coastal wetlands to sea-level rise. Nature 561.7722, pp. 231-234.

Schumm, S. (1967). Meander wavelength of alluvial rivers. Science 157.3796, pp. 1549-1550.

Schumm, S. (1968). Speculations concerning paleohydrologic controls of terrestrial sedimentation. Geological Society of America Bulletin 79.11, pp. 1573-1588. 
Schwarz, C., T. J. Bouma, L. Q. Zhang, S. Temmerman, T. Ysebaert, and P. M. J. Herman (2015a). Interactions between plant traits and sediment characteristics influencing species establishment and scale-dependent feedbacks in salt marsh ecosystems. Geomorphology 250.December 2015, pp. 298 307. DOI:10.1016/J.GEOMORPH.2015.09.013.

Schwarz, C, T. Bouma, L. Zhang, S Temmerman, T Ysebaert, and P. Herman (2015b). Interactions between plant traits and sediment characteristics influencing species establishment and scale-dependent feedbacks in salt marsh ecosystems. Geomorphology 250, pp. 298-307.

Schwarz, C., O. Gourgue, J. Van Belzen, Z. Zhu, T. J. Bouma, J. Van De Koppel, G. Ruessink, N. Claude, and S. Temmerman (2018). Self-organization of a biogeomorphic landscape controlled by plant life-history traits. Nature Geoscience 11.9, pp. 672-677.

Schwarz, C., Q. Ye, D. van der Wal, L. Zhang, T Bouma, T Ysebaert, and P. Herman (2014). Impacts of salt marsh plants on tidal channel initiation and inheritance. Journal of Geophysical Research: Earth Surface 119.2, pp. 385-400.

Schwarz, C., T. Ysebaert, W. Vandenbruwaene, S. Temmerman, L. Zhang, and P. M. Herman (2016). On the potential of plant species invasion influencing bio-geomorphologic landscape formation in salt marshes. Earth Surface Processes and Landforms 41.14, pp. 2047-2057.

Schwarz, C., T. Ysebaert, Z. Zhu, L. Zhang, T. J. Bouma, and P. M. Herman (2011). Abiotic factors governing the establishment and expansion of two salt marsh plants in the Yangtze Estuary, China. Wetlands 31.6, pp. 1011-1021.

Ser, J. and F. Catarino (1999). Fortnightly light and temperature variability in estuarine intertidal sediments and implications for microphytobenthos primary productivity. Aquatic Ecology 33.3, pp. 235241.

Silinski, A., E. Fransen, T. J. Bouma, P. Meire, and S. Temmerman (2016). Unravelling the controls of lateral expansion and elevation change of pioneer tidal marshes. Geomorphology 274, pp. 106-115.

Silvestri, S., A. Defina, and M. Marani (2005). Tidal regime, salinity and salt marsh plant zonation. Estuarine, coastal and shelf science 62.1, pp. 119-130.

Silvestri, S. and M. Marani (2004). Salt-Marsh Vegetation and Morphology: Basic Physiology, Modelling and Remote Sensing Observations. The Ecogeomorphology of Tidal Marshes (eds S. Fagherazzi, M. Marani and L. K. Blum), American Geophysical Union, Washington, D. C., pp. 5-25.

Singer, A., G. Millat, J. Staneva, and I. Kroencke (2017). Modelling benthic macrofauna and seagrass distribution patterns in a North Sea tidal basin in response to 2050 climatic and environmental scenarios. Estuarine, Coastal and Shelf Science 188, pp. 99-108.

Singer, A. et al. (2016). Small-scale benthos distribution modelling in a North Sea tidal basin in response to climatic and environmental changes (1970s-2009). Marine Ecology Progress Series 551, pp. 13 30 .

Slangen, A., M. Carson, C. Katsman, R. Van de Wal, A. Köhl, L. Vermeersen, and D. Stammer (2014). Projecting twenty-first century regional sea-level changes. Climatic Change 124.1-2, pp. 317-332.

Smith, A. J., B. P. Baldigo, B. T. Duffy, S. D. George, and B. Dresser (2019). Resilience of benthic macroinvertebrates to extreme floods in a Catskill Mountain river, New York, USA: Implications for water quality monitoring and assessment. Ecological Indicators 104, pp. 107-115.

Snelgrove, P. V. (1998). The biodiversity of macrofaunal organisms in marine sediments. Biodiversity of Conservation 7.9, pp. 1123-1132.

Soissons, L. M., T. Gomes da Conceiçâo, J. Bastiaan, J. van Dalen, T. Ysebaert, P. M. J. Herman, F. Cozzoli, and T. J. Bouma (2019). Sandification vs. muddification of tidal flats by benthic organisms: A flume study. English. Estuarine, Coastal and Shelf Science 228. Cited By :4.

Solari, L, M Van Oorschot, B Belletti, D Hendriks, M Rinaldi, and A Vargas-Luna (2016). Advances on modelling riparian vegetation hydromorphology interactions. River Research and Applications 32.2, pp. 164-178.

Staats, N, E. De Deckere, B Kornman, W van der Lee, R Termaat, J Terwindt, and B de Winder (2001). Observations on suspended particulate matter (SPM) and microalgae in the Dollard Estuary, The 
Netherlands: Importance of late winter ice cover of the intertidal flats. Estuarine, Coastal and Shelf Science 53.3, pp. 297-306.

Stallins, J. A. and D. Corenblit (2018). Interdependence of geomorphic and ecologic resilience properties in a geographic context. Geomorphology 305, pp. 76-93.

Stark, J, P Meire, and S Temmerman (2017). Changing tidal hydrodynamics during different stages of eco-geomorphological development of a tidal marsh: A numerical modeling study. Estuarine, Coastal and Shelf Science 188, pp. 56-68.

Stark, J, T Van Oyen, P Meire, and S Temmerman (2015). Observations of tidal and storm surge attenuation in a large tidal marsh. Limnology and Oceanography 60.4, pp. 1371-1381.

Steele, J. H., S. A. Thorpe, and K. K. Turekian (2001). Encyclopedia of ocean sciences.

Steiger, J. and D. Corenblit (2012). The emergence of an evolutionary geomorphology?. Open Geosciences 4.3, pp. 376-382.

Stein, W. E., C. M. Berry, L. V. Hernick, and F. Mannolini (2012). Surprisingly complex community discovered in the mid-Devonian fossil forest at Gilboa. Nature 483.7387, pp. 78-81.

Stein, W. E., F. Mannolini, L. V. Hernick, E. Landing, and C. M. Berry (2007). Giant cladoxylopsid trees resolve the enigma of the Earth"s earliest forest stumps at Gilboa. Nature 446.7138, pp. 904-907.

Stein, W. E. et al. (2020). Mid-Devonian Archaeopteris roots signal revolutionary change in earliest fossil forests. Current Biology 30.3, pp. 421-431.

Stevenson, J. C., L. G. Ward, and M. S. Kearney (1986). Vertical accretion in marshes with varying rates of sea level rise. Pp. 241-259.

Stikvoort, E (1996). Habitat-verkenning slikken en platen Westerschelde (in Dutch).

Strain, E. M., J. van Belzen, P. Comandini, J. Wong, T. J. Bouma, and L. Airoldi (2017). The role of changing climate in driving the shift from perennial grasses to annual succulents in a Mediterranean saltmarsh. Journal of Ecology 105.5, pp. 1374-1385.

Strother, P. K. (2000). Cryptospores: the origin and early evolution of the terrestrial flora. The Paleontological Society Papers 6, pp. 3-20.

Suchrow, S. and K. Jensen (2010). Plant species responses to an elevational gradient in German North Sea salt marshes. Wetlands 30.4, pp. 735-746.

Suykerbuyk, W (2019). Watching grass grow: Bottlenecks in seagrass survival.

Tal, M. and C. Paola (2007). Dynamic single-thread channels maintained by the interaction of flow and vegetation. Geology 35.4, pp. 347-350.

Tal, M. and C. Paola (2010). Effects of vegetation on channel morphodynamics: results and insights from laboratory experiments. Earth Surface Processes and Landforms 35.9, pp. 1014-1028.

Talke, S. A. and H. E. De Swart (2006). Hydrodynamics and morphology in the Ems/Dollard estuary: review of models, measurements, scientific literature and the effects of changing conditions.

Temmerman, S, T. Bouma, G Govers, Z. Wang, M. De Vries, and P. Herman (2005a). Impact of vegetation on flow routing and sedimentation patterns: Three-dimensional modeling for a tidal marsh. Journal of Geophysical Research: Earth Surface 110.F4.

Temmerman, S, T. Bouma, G. Govers, and D. Lauwaet (2005b). Flow paths of water and sediment in a tidal marsh: Relations with marsh developmental stage and tidal inundation height. Estuaries and Coasts 28.3, pp. 338-352.

Temmerman, S, T. Bouma, J Van de Koppel, D Van der Wal, M. De Vries, and P. Herman (2007). Vegetation causes channel erosion in a tidal landscape. Geology 35.7, pp. 631-634.

Temmerman, S., G. Govers, S Wartel, and P Meire (2003). Spatial and temporal factors controlling short-term sedimentation in a salt and freshwater tidal marsh, Scheldt estuary, Belgium, SW Netherlands. Earth Surface Processes and Landforms: The Journal of the British Geomorphological Research Group 28.7, pp. 739-755.

Temmerman, S., G. Govers, S. Wartel, and P. Meire (2004). Modelling estuarine variations in tidal marsh sedimentation: response to changing sea level and suspended sediment concentrations. Marine Geology 212.1-4, pp. 1-19. 
Temmerman, S. and M. L. Kirwan (2015). Building land with a rising sea. Science 349.6248, pp. 588589.

Temmerman, S., P. Meire, T. J. Bouma, P. M. Herman, T. Ysebaert, and H. J. De Vriend (2013). Ecosystembased coastal defence in the face of global change. Nature 504.7478, pp. 79-83.

Thrush, S. F., J. E. Hewitt, M. Gibbs, C. Lundquist, and A. Norkko (2006). Functional role of large organisms in intertidal communities: community effects and ecosystem function. Ecosystems 9.6, pp. 1029-1040.

Thrush, S. F., J. E. Hewitt, A. Norkko, P. E. Nicholls, G. A. Funnell, and J. I. Ellis (2003). Habitat change in estuaries: predicting broad-scale responses of intertidal macrofauna to sediment mud content. Marine Ecology Progress Series 263, pp. 101-112.

Tinoco, R., E. Goldstein, and G Coco (2015). A data-driven approach to develop physically sound predictors: Application to depth-averaged velocities on flows through submerged arrays of rigid cylinders. Water Resources Research 51.2, pp. 1247-1263.

Townend, I. (2012). The estimation of estuary dimensions using a simplified form model and the exogenous controls. Earth Surface Processes and Landforms 37.15, pp. 1573-1583.

Townend, I., C. Fletcher, M. Knappen, and K. Rossington (2011). A review of salt marsh dynamics. Water and Environment Journal 25.4, pp. 477-488.

Townend, I. and J. Pethick (2002). Estuarine flooding and managed retreat. Philosophical Transactions of the Royal Society of London. Series A: Mathematical, Physical and Engineering Sciences 360.1796, pp. 1477-1495.

Turner, R., E. Swenson, and C. Milan (2002). Organic and inorganic contributions to vertical accretion in salt marsh sediments. In: Concepts and controversies in tidal marsh ecology. Springer, pp. 583595.

Van Dijk, W. et al. (2019a). The vulnerability of tidal flats and multi-channel estuaries to dredging and disposal.

Van Dijk, W. M., M. Hiatt, J. van der Werf, and M. G. Kleinhans (2019b). Effects of shoal margin collapses on the morphodynamics of a sandy estuary. Journal of geophysical research. Earth surface 124.1, p. 195.

Van Prooijen, B. C., F. Montserrat, and P. M. Herman (2011). A process-based model for erosion of Macoma balthica-affected mud beds. Continental Shelf Research 31.6, pp. 527-538.

Van Wesenbeeck, B., J. Van De Koppel, P. MJ Herman, and T. J. Bouma (2008). Does scale-dependent feedback explain spatial complexity in salt-marsh ecosystems?. Oikos 117.1, pp. 152-159.

Van Belzen, J. et al. (2017). Vegetation recovery in tidal marshes reveals critical slowing down under increased inundation. Nature Communications 8, p. 15811.

Van Damme, S., B. De Winder, T. Ysebaert, and P. Meire (2001). Het'bijzondere'van de Schelde: de abiotiek van het Schelde-estuarium (in Dutch). De Levende Natuur: tijdschrift voor Natuurbehoud en Natuurbeheer 2.

Van Damme, S., T. Ysebaert, P. Meire, and E. Van den Bergh (1999). Habitatstructuren, waterkwaliteit en leefgemeenschappen in het Schelde-estuarium (in Dutch).

Van de Koppel, J., T. J. Bouma, and P. M. Herman (2012). The influence of local-and landscape-scale processes on spatial self-organization in estuarine ecosystems. Journal of Experimental Biology 215.6, pp. 962-967.

Van de Koppel, J., P. M. Herman, P. Thoolen, and C. H. Heip (2001). Do alternate stable states occur in natural ecosystems? Evidence from a tidal flat. Ecology 82.12, pp. 3449-3461.

Van de Lageweg, W. I., L. Braat, D. R. Parsons, and M. G. Kleinhans (2018). Controls on mud distribution and architecture along the fluvial-to-marine transition. Geology 46.11, pp. 971-974.

Van de Vijsel, R. C., J. van Belzen, T. J. Bouma, D. van der Wal, V. Cusseddu, S. J. Purkis, M. Rietkerk, and J. van de Koppel (2020). Estuarine biofilm patterns: Modern analogues for Precambrian selforganization. Earth Surface Processes and Landforms 45.5, pp. 1141-1154. 
Van der Wal, D., R. M. Forster, F. Rossi, H. Hummel, T. Ysebaert, F. Roose, and P. M. Herman (2011). Ecological evaluation of an experimental beneficial use scheme for dredged sediment disposal in shallow tidal waters. Marine pollution bulletin 62.1, pp. 99-108.

Van der Wal, D. and P. M. Herman (2012). Ecosystem engineering effects of Aster tripolium and Salicornia procumbens salt marsh on macrofaunal community structure. Estuaries and coasts 35.3, pp. 714-726.

Van der Wal, D., G. I. Lambert, T. Ysebaert, Y. M. Plancke, and P. M. Herman (2017). Hydrodynamic conditioning of diversity and functional traits in subtidal estuarine macrozoobenthic communities. Estuarine, Coastal and Shelf Science 197, pp. 80-92.

Van der Wal, D., P. Herman, R. Forster, T Ysebaert, F Rossi, E Knaeps, Y. Plancke, and S. Ides (2008). Distribution and dynamics of intertidal macrobenthos predicted from remote sensing: response to microphytobenthos and environment. Marine Ecology Progress Series 367, pp. 57-72.

Van der Wegen, M and J. Roelvink (2012). Reproduction of estuarine bathymetry by means of a processbased model: Western Scheldt case study, the Netherlands. Geomorphology 179, pp. 152-167.

Van Der Wal, D., P. M. Herman, and A. Wielemaker-van Den Dool (2005). Characterisation of surface roughness and sediment texture of intertidal flats using ERS SAR imagery. Remote sensing of environment 98.1, pp. 96-109.

Van Duin, W. and C Sonneveld (2016). Vegetatie en opslibbing in de Peazemerlannen en het referentiegebied West-Groningen: Jaarrapport 2015. Tech. rep. IMARES.

Van Eck, G. T. M. (1999). De Scheldeatlas, een beeld van een estuarium (in Dutch).

Van Hulzen, J., J Van Soelen, and T. Bouma (2007). Morphological variation and habitat modification are strongly correlated for the autogenic ecosystem engineerSpartina anglica (common cordgrass). Estuaries and Coasts 30.1, pp. 3-11.

Van Ledden, M, W. Van Kesteren, and J. Winterwerp (2004). A conceptual framework for the erosion behaviour of sand-mud mixtures. Continental Shelf Research 24.1, pp. 1-11.

Van Oorschot, M, M. Kleinhans, G. Geerling, G Egger, R. Leuven, and H Middelkoop (2017). Modeling invasive alien plant species in river systems: Interaction with native ecosystem engineers and effects on hydro-morphodynamic processes. Water resources research 53.8, pp. 6945-6969.

Van Oorschot, M., M. Kleinhans, G. Geerling, and H. Middelkoop (2016). Distinct patterns of interaction between vegetation and morphodynamics. Earth Surface Processes and Landforms 41.6, pp. 791-808.

Van Rijn, L., D. Walstra, and M. v. Ormondt (2004). Description of TRANSPOR2004 and Implementation in Delft3D-ONLINE. Z3748.

Van Wesenbeeck, B., J Van de Koppel, P. Herman, J. Bakker, and T. Bouma (2007). Biomechanical warfare in ecology; negative interactions between species by habitat modification. Oikos 116.5, pp. 742750.

Van Wesenbeeck, K., J. Van De Koppel, P. Herman, and T. J. Bouma (2008). Does scale-dependent feedback explain spatial complexity in salt-marsh ecosystems?. Oikos 117.1, pp. 152-159.

Vianello, A, A Boldrin, P Guerriero, V Moschino, R Rella, A Sturaro, and L Da Ros (2013). Microplastic particles in sediments of Lagoon of Venice, Italy: First observations on occurrence, spatial patterns and identification. Estuarine, Coastal and Shelf Science 130, pp. 54-61.

Visintainer, T. A., S. M. Bollens, and C. Simenstad (2006). Community composition and diet of fishes as a function of tidal channel geomorphology. Marine Ecology Progress Series 321, pp. 227-243.

Vivian-Smith, G. (2001). Developing a framework for restoration. Handbook for Restoring Tidal Wetlands. CRC Press, Boca Raton, Florida, pp. 39-88.

Volkenborn, N., S. Hedtkamp, J. Van Beusekom, and K. Reise (2007). Effects of bioturbation and bioirrigation by lugworms (Arenicola marina) on physical and chemical sediment properties and implications for intertidal habitat succession. Estuarine, Coastal and Shelf Science 74.1-2, pp. 331343. 
Volkenborn, N., D. M. Robertson, and K. Reise (2009). Sediment destabilizing and stabilizing bioengineers on tidal flats: cascading effects of experimental exclusion. Helgoland Marine Research 63.1, pp. 27-35.

Vos, P., P. De Boer, and R Misdorp (1988). Sediment stabilization by benthic diatoms in intertidal sandy shoals; qualitative and quantitative observations. In: Tide-influenced sedimentary environments and facies. Springer, pp. 511-526.

Vos, P. (2015). Origin of the Dutch coastal landscape: long-term landscape evolution of the Netherlands during the Holocene, described and visualized in national, regional and local palaeogeographical map series. Barkhuis.

Vroom, J., P. de Vet, and J. van der Werf (2015). Validatie waterbeweging Delft3D-NeVla model Westerscheldemonding (in Dutch).

Waeles, B, P Le Hir, P Lesueur, and N Delsinne (2007). Modelling sand/mud transport and morphodynamics in the Seine river mouth (France): an attempt using a process-based approach. Hydrobiologia 588.1, pp. 69-82.

Wang, C. and S. Temmerman (2013). Does biogeomorphic feedback lead to abrupt shifts between alternative landscape states?: An empirical study on intertidal flats and marshes. Journal of Geophysical Research: Earth Surface 118.1, pp. 229-240.

Wang, C., J. Vanlede, W. Vandenbruwaene, Y. Plancke, and S. Temmerman (2015). Historical evolution of mud deposition and erosion in intertidal areas of the Scheldt estuary. In: Scheldt estuary physics and integrated management: proceedings of the 36th IAHR World Congress, 28 June-3 July 2015, Delft $\&$ The Hague, the Netherlands, pp. 61-64.

Wang, Z., A Langerak, and R. Fokkink (1999). Simulation of long-term morphological development in the Western Scheldt. In: Symposium of the International Association for Hydraulic Research, Genova, Italy.

Ward, L. G., W. M. Kemp, and W. R. Boynton (1984). The influence of waves and seagrass communities on suspended particulates in an estuarine embayment. Marine Geology 59.1-4, pp. 85-103.

Wendelboe, K., J. T. Egelund, M. R. Flindt, and T. Valdemarsen (2013). Impact of lugworms (Arenicola marina) on mobilization and transport of fine particles and organic matter in marine sediments. Journal of sea research 76, pp. 31-38.

Whitfield, A., M Elliott, A Basset, S. Blaber, and R. West (2012). Paradigms in estuarine ecology-a review of the Remane diagram with a suggested revised model for estuaries. Estuarine, Coastal and Shelf Science 97, pp. 78-90.

Wiberg, P. L., S. Fagherazzi, and M. L. Kirwan (2019). Improving Predictions of Salt Marsh Evolution Through Better Integration of Data and Models. Annual review of marine science 12.

Wiberg, P. L., S. Fagherazzi, and M. L. Kirwan (2020). Improving predictions of salt marsh evolution through better integration of data and models. Annual review of marine science 12, pp. 389-413.

Widdows, J, M. Brinsley, N Bowley, and C Barrett (1998a). A benthic annular flume for in situ measurement of suspension feeding/biodeposition rates and erosion potential of intertidal cohesive sediments. Estuarine, Coastal and Shelf Science 46.1, pp. 27-38.

Widdows, J, M. Brinsley, P. Salkeld, and C. Lucas (2000). Influence of biota on spatial and temporal variation in sediment erodability and material flux on a tidal flat (Westerschelde, The Netherlands). Marine Ecology Progress Series 194, pp. 23-37.

Widdows, J et al. (2004). Role of physical and biological processes in sediment dynamics of a tidal flat in Westerschelde Estuary, SW Netherlands. Marine Ecology Progress Series 274, pp. 41-56.

Widdows, J. and M. Brinsley (2002). Impact of biotic and abiotic processes on sediment dynamics and the consequences to the structure and functioning of the intertidal zone. Journal of sea Research 48.2, pp. $143-156$.

Widdows, J., M. Brinsley, and M. Elliott (1998b). Use of in situ flume to quantify particle flux (biodeposition rates and sediment erosion) for an intertidal mudflat in relation to changes in current velocity and benthic macrofauna. Geological Society, London, Special Publications 139.1, pp. 85-97. 
Wiehe, P. (1935). A quantitative study of the influence of tide upon populations of Salicornia europea. The Journal of Ecology, pp. 323-333.

Willemsen, P., B. Borsje, S. Hulscher, D Van der Wal, Z Zhu, B Oteman, B Evans, I Möller, and T. Bouma (2018). Quantifying bed level change at the transition of tidal flat and salt marsh: can we understand the lateral location of the marsh edge?. Journal of Geophysical Research: Earth Surface.

Wilson, J. G. and J. W. Fleeger (2012). Estuarine benthos. Estuarine ecology. Hoboken: Wiley Blackwell, pp. 303-325.

Wilson, W. H. J. and K. Parker (1996). The life history of the amphipod, Corophium volutator: the effects of temperature and shorebird predation. Journal of Experimental Marine Biology and Ecology 196.1-2, pp. 239-250.

Winterwerp, J., M. Jeuken, M. Stive, and H. De Vriend (2000). Lange termijnvisie Westerschelde: Cluster morfologie.

Wrede, A., J. Beermann, J. Dannheim, L. Gutow, and T. Brey (2018). Organism functional traits and ecosystem supporting services-A novel approach to predict bioirrigation. Ecological indicators 91 , pp. 737-743.

Wright, S. L., D. Rowe, R. C. Thompson, and T. S. Galloway (2013). Microplastic ingestion decreases energy reserves in marine worms. Current Biology 23.23, R1031-R1033.

Xiao, D., L. Zhang, and Z. Zhu (2009). A study on seed characteristics and seed bank of Spartina alterniflora at saltmarshes in the Yangtze Estuary, China. Estuarine, Coastal and Shelf Science 83.1, pp. 105-110.

Xie, D., C. Schwarz, M. Z. Brückner, M. G. Kleinhans, D. H. Urrego, Z. Zhou, and B. van Maanen (2020). Mangrove diversity loss under sea-level rise triggered by bio-morphodynamic feedbacks and anthropogenic pressures. Environmental Research Letters.

Xue, J. et al. (2016). Belowground rhizomes in paleosols: The hidden half of an Early Devonian vascular plant. Proceedings of the National Academy of Sciences 113.34, pp. 9451-9456.

Yallop, M. L., B. de Winder, D. M. Paterson, and L. J. Stal (1994). Comparative structure, primary production and biogenic stabilization of cohesive and non-cohesive marine sediments inhabited by microphytobenthos. Estuarine, Coastal and Shelf Science 39.6, pp. 565-582.

Yallop, M., D. Paterson, and P Wellsbury (2000). Interrelationships between rates of microbial production, exopolymer production, microbial biomass, and sediment stability in biofilms of intertidal sediments. Microbial ecology 39.2, pp. 116-127.

Ysebaert, T, P. Herman, P Meire, J Craeymeersch, H Verbeek, and C. Heip (2003). Large-scale spatial patterns in estuaries: estuarine macrobenthic communities in the Schelde estuary, NW Europe. Estuarine, coastal and shelf Science 57.1-2, pp. 335-355.

Ysebaert, T., P. Meire, P. Herman, and H. Verbeek (2002). Macrobenthic species response surfaces along estuarine gradients: Prediction by logistic regression. Marine Ecology-Progress Series 225, pp. 7995. DOI:10.3354/MEPS225079.

Zhou, Z., G. Coco, I. Townend, Z. Gong, Z. Wang, and C. Zhang (2018). On the stability relationships between tidal asymmetry and morphologies of tidal basins and estuaries. Earth Surface Processes and Landforms 43.9, pp. 1943-1959.

Zhu, Q, B. van Prooijen, D. Maan, Z. Wang, P Yao, T Daggers, and S. Yang (2019). The heterogeneity of mudflat erodibility. Geomorphology 345, p. 106834.

Zhu, Z., T. J. Bouma, T. Ysebaert, L. Zhang, and P. M. Herman (2014). Seed arrival and persistence at the tidal mudflat: identifying key processes for pioneer seedling establishment in salt marshes. Marine Ecology Progress Series 513, pp. 97-109.

Zhu, Z., F. Cozzoli, N. Chu, M. Salvador, T. Ysebaert, L. Zhang, P. M. Herman, and T. J. Bouma (2016a). Interactive effects between physical forces and ecosystem engineers on seed burial: a case study using Spartina anglica. Oikos 125.1, pp. 98-106.

Zhu, Z., J. van Belzen, T. Hong, T. Kunihiro, T. Ysebaert, P. M. Herman, and T. J. Bouma (2016b). Sprouting as a gardening strategy to obtain superior supplementary food: evidence from a seedcaching marine worm. Ecology 97.12, pp. 3278-3284. 


\section{Acknowledgements}

When I started my PhD in Utrecht, I thought that I can easily use this model Maarten gave me and that the Dutch are like the Germans, but only speak funny. Obviously, I did not know what I was talking about. During the past four years, I eventually got a grip on the model and I learned that the Dutch are not like the Germans at all (but still speak funny). That I had these insights, and many others, was thanks to a lot of people that supported and believed in me, provided me with coffee and chocolate and tried to teach me their wisdom or to protect me from the pitfalls that science inevitably puts in your way.

I am very thankful for the dedicated supervision, constructive advice, and the patient guidance that I received from my supervisors. The understanding, trust and motivation that I received from both Maarten and Christian made me believe in myself and helped me become an excited, thorough and dedicated scientist. Maarten, thank you for being a positive, inspiring and enthusiastic mentor, who always believed in me, had my back and did everything to support me and my development as a scientist. Although I am still not certain where all the low-hanging fruit are that you keep talking about, you inspired me to master the steepest learning curve of my life. Christian, when I struggled with decisions about the model, writing my first paper, or did not know where to start, I knew that I could count on your strategic, objective-oriented advice. You would always make time to listen to my questions and point me to the next stepping stone. I appreciate the dedication and loyalty with which both of you guided me in my pursuit to become a creative and independent researcher. I also want to thank Giovanni for his guidance. Your support has helped me tremendously during the past year and the difficult times of covid19, and I could always count on you making time for me and my research.

I also want to thank my parents, who supported me in all my decisions. Danke, dass ihr mich immer unterstützt und an mich geglaubt habt. Immer, wenn ich neuen Herausforderungen begegnet bin, hattet ihr guten Rat, standet mir zur Seite und habt mich daran erinnert, dass erstmal darüber schlafen auch eine gute Idee ist. Ich bin dankbar für eure Unterstützung und eure Ehrlichkeit, dass ihr immer zu mir steht und mir alles möglich gemacht habt, wo es nur ging.

That I saw the light at the end of the estuary was also thanks to my friends and my partner. You helped me put things in perspective, to evaluate my own skills and reflect on my goals when I myself or others doubted my work. Katha, Lisa and Ludo, you were always by my side with food, coffee and good conversations to discuss research, motivate me and tell me that everything will be fine. Emmy and Anne, I am glad to have shared this time with you, that you always understand what I am talking about and lucky to have you as friends. Ward, thank you for your patience with my sometimes unreasonable expectations, my high ambitions and for always supporting me in my decisions. Fábio, thank you for inspiring and supporting me. You have been solid as a rock during the past months when I ran out of time or patience and helped me with your positive energy through the last weeks of my PhD.

Finally, I am very lucky to have been a part of a large group of PhD's that supported each other and were always available for a coffee or a chat. I want to thank all of you for the great 
times, the coffee breaks and discussions that made my time at the department exceptional. I would like to thank a few of you especially: Sanja, Wout, Jana and Jasper for your advice during the tricky times of my PhD and your support throughout. Marjolein, Jakob and Joeri, I was happy to count on for my lunch entertainment that made my work life much more social and fun. Steven, Lisanne and Márcio, it was great to share nerd stuff about MATLAB and Delft3D, chocolate, cookies and coffee. Will and Job, I am happy to have had your positive support and the occasional coffee break or lunch. Job, also a special thank you for your help with the cover of this work. I also want to thank my students Bente, Dennis, and Inger, who contributed with their ambition and enthusiasm to my research.

I am grateful for the good times I had in Utrecht and that I had the opportunity to become a scientist here. Many things became clear in the course of these past years, I learned that models unfortunately never tell the truth, and I had to accept that I speak a little funny myself now. 


\section{About the author}

Muriel Brückner grew up in Kiel, Germany, a city at the Baltic Sea known for its sailing and trading tradition, where most people come at least once in their lives to take one of the big ferries that go to Scandinavia. In 2009, she moved to the medieval city of Braunschweig to pursue her studies in Environmental Engineering that she graduated from in 2016. During her studies, she went abroad to spend several months living in France and Norway. In France she worked as an intern in a large water consultancy to investigate the efficiency of renewable marine energy technologies. In Norway, Muriel spent a semester studying arctic and marine engineering and biology at the Norwegian University of Science and Technology in Trondheim and wrote her student project with Prof. Jochen Aberle. After that, she decided to come back to Norway in 2015 to write her M.Sc. thesis, studying how the construction of weirs can benefit ecosystem protec-

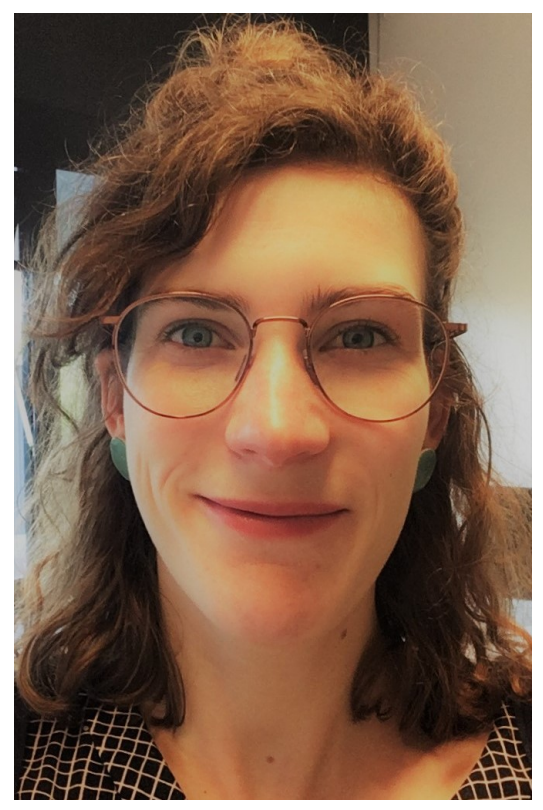
tion and restoration in the Danube river. It was during her second time in Trondheim that she first considered pursuing a career in academia and decided to look for an interesting $\mathrm{PhD}$ position. Muriel has always been excited about the potential to combine ecology with engineering solutions, which she considers as being one important step in humanity's quest to mitigate climate change impacts. This led her to start as a $\mathrm{PhD}$ candidate with Maarten on a topic that would allow her to study how vegetation and benthic species living in the ground alter the evolution of our coastal landscapes.

During her PhD, Muriel got involved in multiple projects, both collaborating with scientists and industry around the world. In her last year, she spent several months at the University of Auckland collaborating with the group of Prof. Giovanni Coco. Throughout her time as a PhD candidate, Muriel contributed to teaching at the department, supervised students, and attended many conferences. In addition, she was part of the Young Women in Geosciences network and represented the PhD community at the department of Physical Geography as Chair. In her free time, Muriel works as a Swing dance teacher and an event organizer within her dancing community. She enjoys hiking and yoga and spends most of her weekends in a café or in nature. 